QL

684

M5C77

Birds

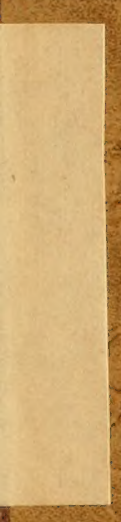

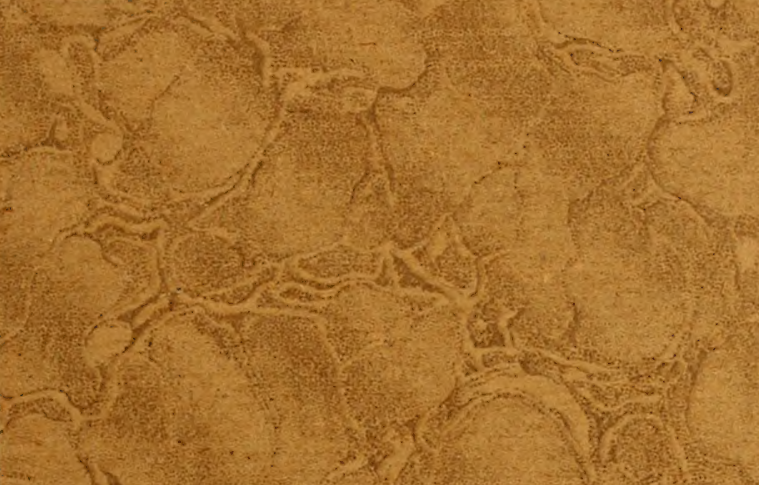

I.

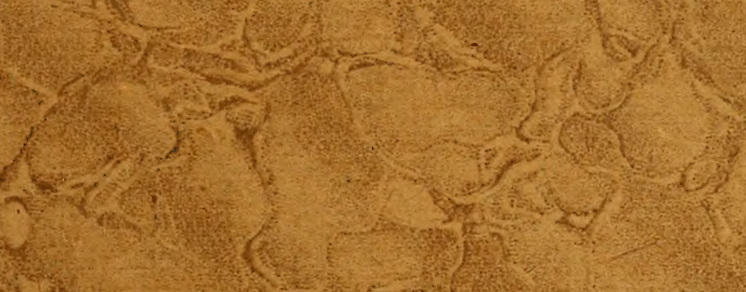

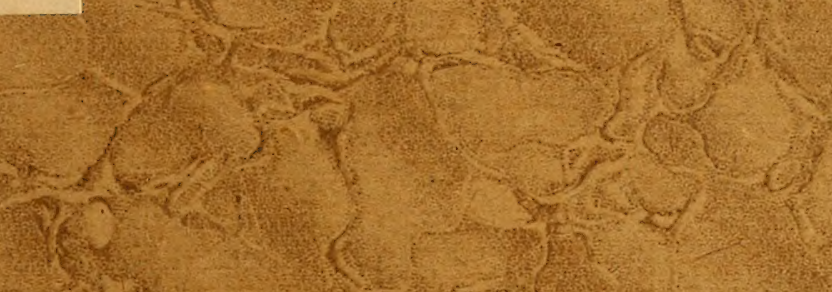

$(5+2)=$

ing

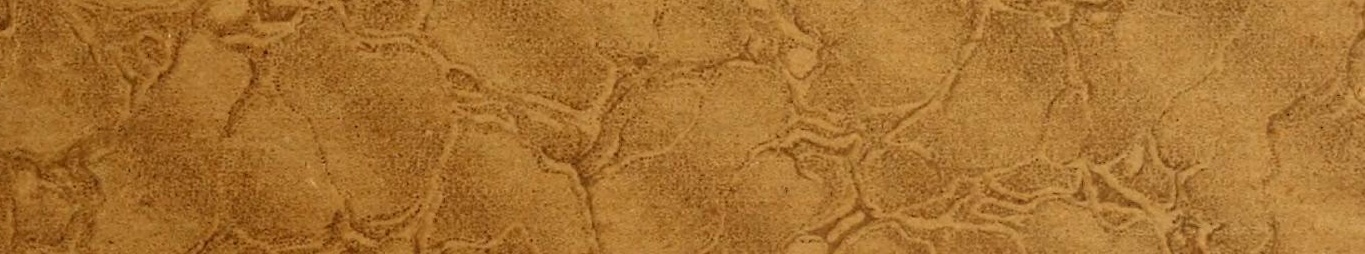

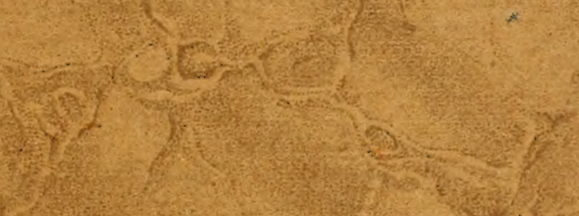

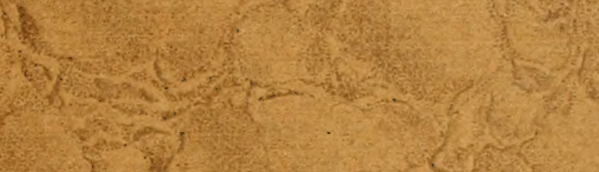

$x^{2}-4$

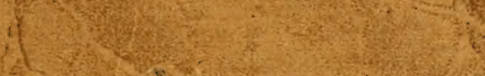

(x)

$3 x^{2}+t^{2}$

is

$(-1+2=-7$.

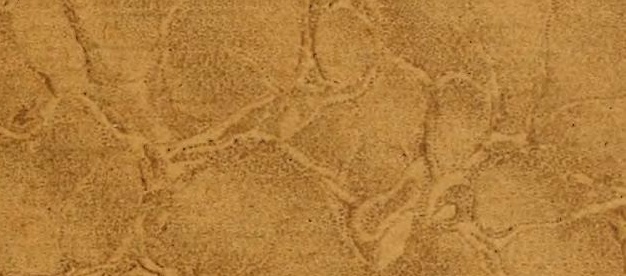

$x^{2}+y=4$

$y \cdot 2-\frac{1}{6}=$

3. $x=5$

1.

3. $-3=$

$+x^{3}$

d) $\operatorname{lin} x^{2}$

cer y

Fich

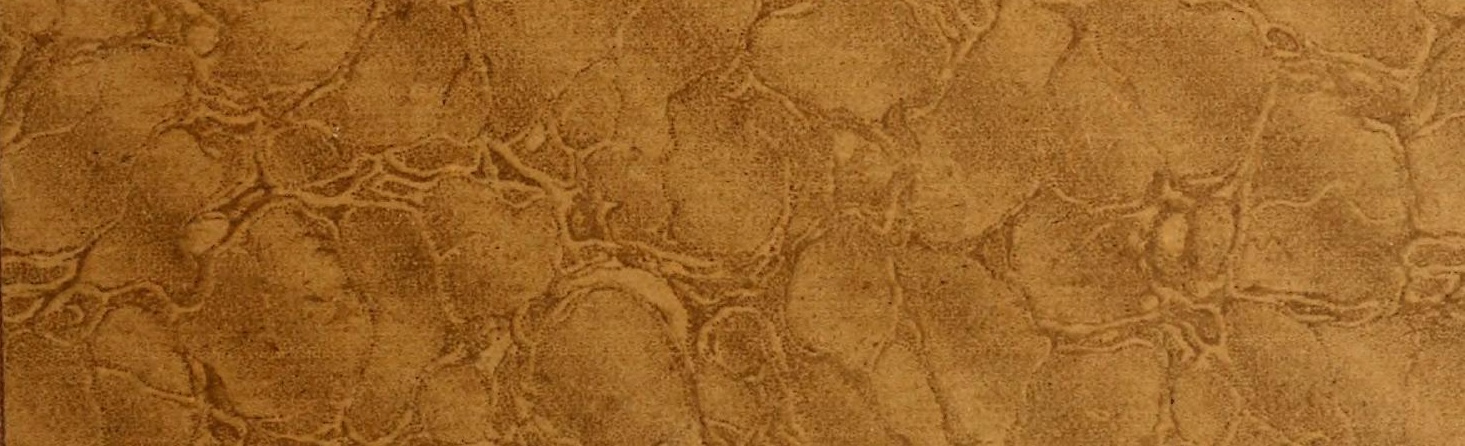

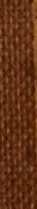




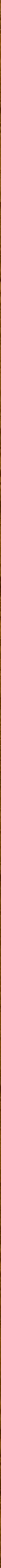




\section{Jíros of \\ (Mícbícgan}

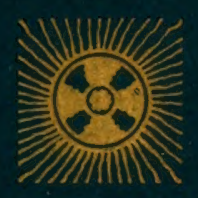

JBe \&. F. Cook ...

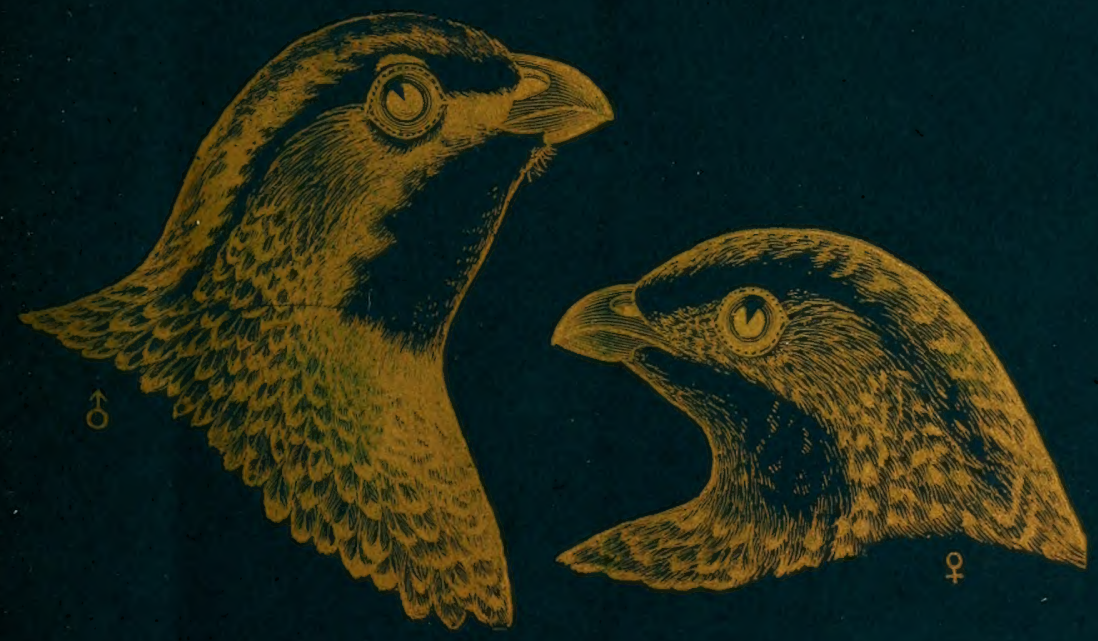

हैos

\section{Silíchigan Elgrícultural College}

JBulletín Ho. 94 

BULLETIN 94.

APRIL, 1893.

\section{MICHIGAN}

AGRICULTURAL EXPERIMENT STATION

STATE AGRICTLTITRAL COLLEGE.

ZOÖLOGICAL DEPARTMENT.

\section{BIRDS OF MICHIGAN}

\section{L L U S T R A T E D}

BY A. J. COOK.

The Bulletins of this Station will be sent free to all newspapers in the State, and to such individuals interested in farming as may request it. Address all applications to the Secretary, Agricultural College, Michigan. 


\section{Michigan agricultural Experiment Station.}

Postoffice Address, - . . . . Agricultural College, Mich.

Railroad, Express and Telegraph Address, . . . . Lansing, Mich.

A DEPARTMENT OF THE STATE AGRICULTURAL COLLEGE, AND, WITH IT, CONTROLLED BY THE

INCORTORATTHD

STATE BOARD OF AGRICULTURE.

Hon. FRANKLIN WELLS, Constantine, President of the Board,

HoN. A. C. GLIDDEN, Paw Paw,

HoN. HENRY CHAMBERLAIN, Three Oaks,

HoN, EDWIN PHELPS, Pontiac,

HoN. CHAS. W. GARFIELD, Grand Rapids,

HoN. I. H. BUTTERFIELD, Lapeer,

HoN. JNO. T. RICH, Elba, Governor of the State,

How. O. ClUTE, M. S., Agricultural College, President of the College,

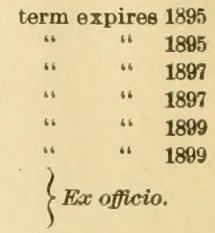

\section{STANDING COMMITTEES OF THE BOARD.}

The President of the Board is ex officio member of each of the standing committees.

Frnanoe, - . C. W. Garfield, A. C. Glidden. Experiment, . I. H. Batterfield, H. Chamberlain. Farm, - I. H. Butterfield, Edwin Phelps. Veterinary, Edwin Phelps, I. H. Butterfield. Garden, - C. W. Garfield, Edwin Phelps. Institutes, A. C. Glidden, C. W. Garfield, O. Clate. Butldings, . A C. Glidden, I. H. Batterfield. Mechanros, . H. Chamberlain C. W. Garfield. Emploxees, H. Chamberlain, A. C. Glidden, O. Clate. Militaky, . C. W. Garfield, I. H. Butterfield. Wrather, . A. C. Glidden, C. W. Garfield. Land Grant, . Edwin Phelp8, H. Chamberlain.

\section{STATION COUNCIL.}

O. Cuute, M. S.

P. M. HaRWOOD, B. S., L. R. TAFT, M. S.;
Agriculturist.

Horticulturist.
Director.

Robert C. Kedzik, M. A., M. D., Chemist. Henry G. Reynolids, M. S., . S Sec. and Treas.

ADVISORY AND ASSISTANT STAFF.

P. G. Holden, B. S., Assistant Agriculturist. F. B. MUMFord, B. S., Assistant in Agriculture, H. P. GladDen, B.S., " "Horticaltare. R. J. CORYELL, B. S. W. L. Rossman, B. S., H. E. Harrison, B. S.,

$$
\begin{aligned}
& \text { " } \\
& \text { " } \\
& \text { " Cherticalture. } \\
& \text { " }
\end{aligned}
$$

E. A. A. Grange, V. S., Consulting Veterinarian. G. C. DAvIS, M. S., " " " " " Chas, F. Wheeler, B. S., " . Botanist. L. A. Cunnton, B. S., Assistant to Director. Mrs. L. E. LANDON, . . . . Librarian.

\section{SUB - S T ATIONS.}

Grayling, Crawford County, 80 acres deeded; Dr. O. Palmer, Local Agent.

South Haven, Van Buren County, 10 acres rented; 5 acres deeded; IIon. T. T. Lyon, President State Horticultural Society, Local Agent. 
Supplementary - The following laws were passed by the legislature of 1893, and received too late for insertion in their proper places among the bird laws.-A. J. C.

AN ACT to amend section two of an act number seventy, of the public acts of one thousand eight hundred and seventy-seven, entitled "An act for the more effectual prevention of cruelty to animals," approved April twenty-fifth, eighteen hundred seventy-seven, being section nine thousand three hundred and ninety-two of Howell's Annotated Statutes.

Section 1. The People of the State of Michigan enact, That section two of act number seventy of the public acts of one thousand eight hundred and seventyseven, entitled "An act for the more effectual prevention of cruelty to animals." approved April twenty-fifth, eighteen hundred seventy-seven, being section nine thousand three hundred and ninety-two of Howell's Annotated Statutes, be and the same is hereby amended so as to read as follows:

SEc. 2. Any person who shall keep or use any bull, bear, dog, cock, or other animal or fowl, or bird, except English sparrows, for the purpose of fighting or baiting, or as a target or to be shot at, either for amusement, or as a test of skill in marksmanship; and any person who shall be a party to, or be present as a spectator, at any such tighting, baiting, or shooting of any bear, dog, cock, or other animal, or fowl, or bird, except English sparrows, and any person who shall rent any building, shed, room, yard, ground or premises, for the purpose of fighting, baiting or shooting any animal, fowl or bird, except English sparrows, as aforesaid, or shall knowingly suffer or permit the use of any building, shed, room, yard, ground, or premises belonging to him or under his control, for either or any of the purposes aforesaid, shall on conviction thereof, be adjudged guilty of a misdemeanor: Provided, That no bounty shall be paid for any English sparrow that may be killed when used as a target, or to be shot at either for amusement or as a test of skill in marksmanship: And provided, That it shall not be lawful for any person or persons to engage in the propagation of English sparrows for the purpose allowed in this act or for any other purpose; and that on conviction for each or any offense mentioned in this act, the person or persons so convicted shall pay a fine of not less than ten (10) nor more than fifty (50) dollars, or be imprisoned in the county jail for a period of not more than ninety (90) days, or by both such fine and imprisonment in the discretion of the court.

This act is ordered to take immediate effect.

Approved April 27, 1893.

AN ACT to amend sections one and two of act number one hundred and fifty-two of the session laws of eighteen hundred and eighty-nine, being "An act to amend sections one, two and three of act number twenty-nine of the public acts of eighteen hundred and eighty-seven," approved March fifteen, eighteen hundred and eighty-seven, entitled "An act to provide for the payment of bounties for the killing of English sparrows," as amended by act number one hundred and fifty-two of the public acts of eighteen hundred and eighty-nine.

Section 1. The People of the State of Michigan enact, That sections one and two of act number twenty-nine, of the public acts of eighteen hundred and eightyseven, approved March fifteen, eighteen hundred and eighty seven, entitled "An act to provide for the payment of bounties for the killing of English sparrows," as amended by act number one hundred and fifty-two of the public acts of eighteen hundred and eighty-nine, be amended so as to read as follows:

Section 1. The People of the State of Michigan enact, That every person being an inhabitant of this State, who shall kill "during the months of November. December, January, February and March" an English sparrow in any organized township, village, or city in this State, shall be entitled to receive a bounty of three cents for each sparrow thus killed, to be allowed and paid in the manner hereinafter provided.

Sec. 2. Every person applying for such bounty shall within said months take such sparrows in lots of not less than ten, to the clerk of the township, village or 
city, within which such sparrows shall have been killed, "and shall thereupon make oath that such sparrows were killed during the aforesaid months mentioned in section one of this act and at no other time."

Said clerk shall thereupon decide upon such application, and if satisfied of the correctness of such claim, shall issue a certificate stating the amount of bounty to which such applicant is entitled and deliver the same to said applicant, and shall destroy such sparrows.

This act is ordered to take immediate effect.

Approved April 27, 1893.

AN ACT providing for the protection of Antwerp and homing pigeons.

Section 1. The People of the State of Michigan enact, That on and after the passage of this act it shall be unlawful for any person or persons to wilfully shoot, maim or kill any Antwerp or homing pigeon, either in flight or at rest, and any person guilty of wilfully killing, shooting or maiming such pigeon or pigeons as aforesaid, shall be guilty of a misdemeanor and upon conviction thereof shall for every such offense pay a fine of not less than ten nor more than twenty-five dollars, or be punished by imprisonment in the county jail not to exceed ninety days. or by both such fine and imprisonment in the discretion of the court.

SEC. 2. That it shall be unlawful for any person or persons to detain or entrap any Antwerp or homing pigeon: Provided, however, That such Antwerp or homing pigeon shall have the name of its owner stamped on its wing or tail or which may be identified by any device or mark, and any person or persons so detaining such pigeon or pigeons shall be deemed guilty of a misdemeanor, and upon conviction thereof before any justice of the peace or other court of competent jurisdiction shall for every offense pay a fine of not less than ten or not more than twenty-five dollars or be punished by imprisonment in the county jail not exceeding ninety days, or both such fine and imprisonment at the discretion of the court.

This act is ordered to take effect June first, eighteen hundred and ninety-three.

Approved May 24, 1893.

AN ACT to prevent the killing, hunting, or molesting in any way of Mongolian and English pheasant for a period of five years, and to regulate the time for hunting and for selling or offering for sale the same after that period.

Section 1. The People of the State of Michigan enact, That no person or persons shall pursue, hunt, kill, or attempt to kill or molest in any way whatever any Mongolian and English pheasants until the first day of November eighteen hundred and ninety-eight, and then only from the first day of November to the fifteenth day of December, inclusive, in each year.

SEc. 2. No person, firm or corporation shall for a period of ten years from and after the passage of this act sell. or attempt to sell. or expose for sale, or ship or transport out of this state, or attempt to ship or transport outside of this state or have in possession for the purpose of shipping or transporting outside of this state any Mongolian and English pheasant.

SEC. 3. Any person or persans violating the provisions of this act shall be guilty of a misdemeanor, and on conviction thereof shall be punished by a fine of not less than ten dollars nor more than fifty dollars, together with the costs of prosecution, and in default of the payment of the same shall be imprisoned in the county jail for a period not exceeding thirty days, or both such fine and imprisonment, in the discretion of the court.

Approved March 30, 1893. 


\section{INTRODUCTION.}

Of the several lists of the birds of Michigan, from that of Dr. Abram Sager. published in 1839, to the most recent by Dr. Morris Gibbs, published in the Ornithologist and Oölogist, Vol. 10, 1885, not one is accessible to the younger students of ornithology. While some of the lists are quite full and accurate, not one gives the food and nesting habits of our birds. Such a list can but fill a pressing need, and must receive a most hearty welcome. Indeed I have had frequent inquiries for a cata logue by my students and others, and often have been urged to prepare a list.

Owing to my very numerous duties at the college, and my greater interest in the study of entomology I have, previous to this time, been unable to give any time to this work. The past summer the valuable manuscripts of the late Dr. H. A. Atkins came into my hands, and the State Board of Agriculture voted that I should prepare a list, to be sent out as a bulletin by the experiment station.

Having taught ornithology for the past twenty-six years at the Michigan Agricultural College to large classes, in which there were many good observers who had already made some progress in this study, and who represented many sections of the State, and having in the meantime made quite a considerable collection, through the aid of my students, of 'birds and birds' eggs for our museum, of which I have had the entire charge, I have been able to gather many and some valuable facts regarding the birds of our State.

I have also had in my possession all the manuscripts of the late Dr. H. A. Atkins, of Locke, Michigan, who was for twenty-nine years a most enthusiastic and conscientious student of this branch of natural history. Dr. Atkins kept a careful record of the birds of Locke, Ingham County, Michigan, with the date of the capture of each species, the time of the first appearance and exit, each year, and the full dates of all migrations. This record was very full and accurate, considering the meager literature that Dr. Atkins had at his command. Dr. Atkins visited me quite frequently, and I am assured of his entire devotion to this science, and his earnest effort to secure all possible accuracy in his determination of species and his statements of facts. I have received valuable aid from Dr. Atkins' carefully prepared manuscript, and have starred every bird that he reported from our State. For the dates, nesting habits, number and colors of eggs, I am much indebted to these manuscripts, which, through the kindness of Mrs. Atkins, were put in my possession. Nearly all the birds reported by Dr. Atkins have also been taken here, and so have come under my own personal observation. Dr. Atkins' observations were nearly all made at Locke, and the species starred were all taken at that place, unless special mention is made to the contrary.

I have also received great assistance from Prof. A. W. Butler, of Brookville, Indiana. 
I have not only profited from his excellent "Birds of Indiana" (one of our most complete and most admirably arranged list of birds), but he has kindly reviewed my list and offered most valuable suggestions, has loaned me books and papers, and has given me very valuable assistance in the preparation of the bibliography.

I have profited much from the accurate lists of Michigan birds, prepared by Dr. Morris Gibbs of Kalamazoo, Michigan, from his many valuable articles in the several ornithological papers, and additions, corrections and suggestions given me in the preparation of this list. Dr. Gibbs has also helped me very much in the preparation of the bibliography.

The kindness of Professor J. A. Allen, and Drs. Elliott Cones, C. Hart Merriam, A. K. Fisher and Robert Ridgway in reviewing a preliminary list, and suggesting important changes, is most heartily appreciated. I have also received very great aid from the valuable manuals of Drs. Coues, Ridgway and Jordan, the excellent treatises of Samuels and Davie, and the other American works that treat of birds. I have been materially aided by my many students, especially Mr. C. B. Cook and L. Whitney. Watkins, and by the many correspondents whose names appear in the text, especially Messrs. A. H. Boies, Hudson; Jerome Trombley, Petersburg; Stewart E. White, Grand Rapids; Profs. J. W. Simmons. Owosso; and James Satterlee, Greenville; Drs. J. B. Steere, Ann Arbor; W. C. Brownwell, Morrice, and Messrs. J. B. Purdy, Plymouth; F. M. Falconer, Hillsdale; E. E. Brewster, Iron Mountain; Ludwig Kumlein, Milton, Wisconsin; E. L. Moseley, Sandusky, Ohio; H. Nehrling, custodian city museum, Milwaukee, Wisconsin; C. S. Osborn, Sault Ste. Marie; M. L. Leach, Traverse City; Dudley E. Waters, Grand Rapids; and L. S. Foster of New York City.

The admirable illustrations were received through the kindness of Messrs. Estes and Lauriat, and are the same that are used by Dr. Coues to illustrate his valuable Manual of North American Birds. The illustration for the European Sparrow was received through the courtesy of Dr. Edwin Willits of the Department of Agriculture.

I have adopted the arrangement of the American Ornithological Union, and so give after the serial number of each species the number of the species as it occurs in the Union list. I have also appended in parenthesis, the number of the species as given in Coues' Key and Check List. This is for the convenience of beginners, who have or should have this valuable manual.

These numbers will prove of great convenience in correspondence and in making exchanges. Although I strongly recommend every student of birds and every would be student to procure Coues' Key to the Birds of North America, I have not used his arrangement or nomenclature, as they are not what he would use were he preparing his work today; but as I have given his numbers, there would be no difficulty in using this list and his invaluable book, which I regard as near perfection as any work of the kind which I have ever seen in any line of science. This list will enable any student to correct Coues' nomenclature according to the accepted nomenclature of the Ornithological Union, which was prepared by a committee of which Dr. Coues was himself a member. In the back part of the last edition of Dr. Coues' Key will be found the two nomenclatures side by side.

\section{PECULIARITIES OF OUR MICHIGAN BIRD FAUNA.}

Our bird fauna, like our entire fauna, owing to the protection given by the great lakes, which nearly surround us, is very interesting. As Dr. C. Hart Merriam has shown by a colored map, issued by the Department of Agriculture in March, 1892, we have 
three distinct faune represented in our State: The Boreal in the north, which includes our Northern Peninsula and the northern part of the Southern Peninsula; the Transition, which occupies nearly all of the Southern Peninsula and reaches slightly into Indiana and Ohio; and the Upper Sonoran, which though mostly to the south of us, reaches into the southeastern and southwestern corners of the State. Thus we meet in Michigan many birds peculiar to the far north, and others that dwell for the most part in the states and countries south of us, even reaching to or beyond the gulf. The first are illustrated in the Bohemiam Wax-wing, the Spruce Partridge, the Canada Jay and the Pine Grosbeak; while the Summer Red Bird, the Mocking Bird and the Cardinal Rerl Bird illustrate the second group. The large lakes attract to us many birds that are usually maritime, like the gulls and the terns; while in southern Michigan, with its prairies and woodlands both widely distributed, we get the prairie fauna, illustrated in the Pinnated Grouse, as well as those birds which are most at home in the forests of wooded areas, like most of the thrushes and the warblers. This accounts for the very large list of woodland warblers which we find in our state.

The following birds have been reported from Michigan, but after as full inquiry as I am able to make, I do not feel warranted in admitting them to this list: Sula bassana. Anhinga anhinga. Camptolaimus labradorius, Souateria mollissima boreallis, Ardea corulea, Nycticorax violaceus, Rallus longirostris crepitans, Tringa maritima, Pavoncella pugnax. Hiematopus palliatus, Jacana spinosa, Dendragapus franklinii. Sayornis saya, Quiccalus quiscula, Acanthis hornemanii exilipes, Milvulus tyrannus, Ammodramus leconteii, Dendroica dominica, Sitta pusilla. Parus carolinensis. and Sialia aretica. There are a few more that seem to be of very doubtful occurrence in our State, but I do not feel warranted in excluding them, but have expressed doubt as to their belonging to our Michigan fauna in the text.

I have appended to this introduction, not only as complete a bibliography as my time and resources would permit, but also our "Michigan Bird Laws," which are usually excellent, and very wholesome in their influence.

In the text I have recorded such facts regarding the food habits of our birds as will enable every one to judge of the economic importance of the various species. Where possible, as it is in most cases, I have given the food habits of the entire family and omitted a mention of them in speaking of the separate species.

It will be observed that I have secured records from the southern part of the state from Messrs. Boies, Trombley and Simmons; from the southern central from Messrs. Purdy, Steere and Gibbs; from the central, from Messrs. Atkins. Brownell, White. Moseley, etc; from the north central, from Professor Satterlee and others; from the northern extremity of the southern peninsula, from Messrs. Leach, White, Boise. Osborn, etc., and from the northern peninsula, from Messrs. White, Boise, Brewster, Kumlein. Kneeland and others. Thus the observations. most of them continued for a long series of years, and made by trained observers have covered pretty thoroughly the entire State. 


\section{PROTECTION OF GAME.}

ACT 276. OF THE LAWS OF 1889.

2215h. SEc. 8. No person or persons shall kill or destroy, by any means, whatever, or attempt to take or destroy, any wild turkey at any time except in the months of October and November of each year.

2215i. SEc. 9. No person or persons shall kill or destroy, by any means whatever, any woodcock or any partridge or ruffed grouse. save only from the first day of Septem. ber in each year to the first day of January following.

2215j. Sec. 10. No person or persons shall kill or destroy, by any means whatever, any wild duck, wild goose, or other wild water fowl or snipe, save only from the first day of September in each year to the first day of January in the year following: Provided, hovever, That it shall be lawful to hunt and kill jack-snipe, red-headed, bluebill, canvas-back, widgeon, pin-tail ducks and wild geese, between the first day of September in each year and the first day of May next following.

2215k. SEc. 11. The taking, carrying, or sending by any means whatever into or through any county of this state, any of the game or animals which have been killed or eaptured contrary to the provisions of this act, or the hide of such animals, shall be illegal, and is declared to be an offense against the provisions of this act, in any county in or through which such game, animals, or hides may be taken.

22151. Sec. 12. No person shall kill, capture, or destroy, or attempt to kill, capture, or destroy any colin or quail, sometimes called Virginia Partridge. before the first day of November, 1894, and thereafter only during the months of November and December of each year.

2215m. SEc. 13. No person shall kill or attempt to kill any pinnated grouse or prairie chicken until the first day of September, 1894. and thereafter only in the months of September and October in each year.

$2215 n$. Sec. 14. No person or persons shall at any time take or capture or attempt to take or eapture any turkeys, partridge prairie chicken, pigeon, wild duck, wild groose or quail by means of nets. snares, pits, pitfalls, or eages: Provided, That it shall be lawful to trap quail and take them alive for the purpose of keeping them alive through the winter and for no other purpose whatever. Said quail are not to be transported to other places, but must be again liberated in the same place where they were cauglit when the weather is suitable in the spring.

22150. SEC. 15. No person shall, at any time, make use of a swivel or punt gun for the purpose of killing, or attempting to kill, any wild duck or other wild fowl.

2215p. SFe. 16. No person shall, at any time, in any manner, rob. or destroy, or 
injure the nest of any wild duck or other wild fowl, nor in any manner lkill or molest the same at night or at any other time on their nesting places.

2215q. SEc. 17. No person or persons shall sell or expose for sale, or have in his possession for the purpose of selling or exposing for sale, any of the kinds or species of birds or animals protected by this act after the expiration of eight days next succeeding the times limited and preseribed for the killing of any such birds or animals : Provided, hovever, That it shall be lawful to expose for sale and to sell any live quail for the purpose of preserving the same alive through the winter. And it shall also be lawful for any person to take alive, on his own premises, at any time and in any manner, any wood duck, teal duck, or mallard duck, or wild turkey, for the sole purpose of domestication or for scientific or breeding purposes, and possession and transportation alive of such wild fowl, so taken on one's own premises, may be had for any such purpose: Provided, That in any prosecution for violation of any of the provisions of this act, the person claiming the benefit of this section shall prove on the hearing or trial that in good faith he so took alive such wild fowl or fowls for one of the purposes specified in this section, and if prosecuted for transporting them, that he is in good faith transporting them alive for such purpose; and it shall not be necessary for the prosecution to aver or prove that the taking alive of any such wild fowl or fowls was not done for domestication or for scientific or for breeding purposes.

2215r. SEc. 18. Any person or persons violating any of the foregoing provisions of this act shall be deemed guilty of a misdemeaner, and shall likew ise be liable to a penalty of fifty dollars for each offense, and shall, on conviction thereof, stand committed to the common jail of the county until such penalty is paid: Provided, That such imprisonment shall not exceed thirty days.

2215s. SEc. 19. Any person who shall, at any time, within this state, kill any robin, nighthawk, whippoorwill, finch, thrush, lark, swallow, yellow bird, blue bird, brown thrasher, wren, martin, oriole, woodpecker, bobolink, or any song bird, or rob the nests of such birds, shall be deemed guilty of a misdemeanor, and on conviction thereof, shall be fined five dollars for each bird so killed, and for each nest so robbed, or confined in the county jail for ten days, or both such fine and imprisonment, in the discretion of the court.

2215t. SEC. 20. That any railroad, express company, or other common carriers, or any of their agents or servants or other persons having any of the above named birds or animals in their possession for transportation, or shall transport the same after the expiration of five days next succeeding the time limited 'and prescribed for the killing: of such birds and animals, shall be punished by fine not less than ten dollars nor more than one hundred dollars: Provided, That no such penalty shall apply to the transportation of live quail which are to be kept alive throughout the winter, or to the transportation of such birds or animals in transit through the state from other states where it is lawful to kill such birds or animals at the time of such transportation.

2215u. SEc. 21. No person or persons shall use any gun or guns, or fire-arms to maim, kill or destroy any wild pigeon or pigeons, at or within five miles of the place or places where they are gathered in bodies for the purpose of brooding their young. known as pigeon nestings; and no person or persons shall use any gun or guns, or firearms, to maim. kill, or destroy, any wild pigeon or pigeons within their roostings, anywhere within the limits of this state; and no person or persons shall, with trap, snare, or net, or in any other manner, take, or attempt to take, kill or destroy, or attempt to kill or destroy. any wild pigeon or pigeons, at or within two miles of such nesting place 
at any time from the beginning of the nesting until after the last hatching of such nesting, anywhere within the limits of this state; and every person offending against the provisions of this section, or any part thereof, shall be subject to a penalty of fifty dollars with costs of suit.

2215v. SEC. 22. A prosecution may be brought by any person in the name of the people of the state of Michigan, against any person or persons violating any of the provisions of this act before any justice of the peace of the county in which such violation is alleged to have taken place, or before any court of competent jurisdiction; and it is made the duty of all prosecuting attorneys in this state to see that the provisions of this aet are enfored in their respective counties. and they shall prosecute all offenders. on receiving information of the violation of any of the provisions of this act; and it is made the duty of sheriffs, under sheriffs, deputy sheriffs. constables and police officers. to inform against and prosecute all persons who there is probable cause to believe are guilty of violating any of the provisions of this act.

2215w. SEc. 23. The state game and fish warden is hereby authorized to issue permits for the hunting and killing any kind of bird out of season, said hird being sought exclusively as specimens for scientific purposes.

2215x. SEC. 24. All prosecutions under the provisions of this act shall be commenced within one year from the time such offense was committed.

2215y. SEC. 25. All acts and parts of acts in conflict with the provisions of this act are hereby repealed.

DESTRUCTION OF ENGLISH SPARROW'.

2259a. 1885, p. 4, Feb. 17, act 4. SECTION 1. The People of the State of Michigan enact, That it shall be lawful to kill the birds commonly called "English sparrows."

SEC. 2. All acts heretofore passed, contrary to the provisions of the preceding section, are hereby repealed.

2259b. 188\%, p. 29, Mar. 15, Act 29; Am.1889, p. 171, June 17, Act 152. Section 1. The People of the State of Michigan enact. That every person. being an inhabitani of this state, who shall kill an English sparrow in any organized township, village or city in this state shall be entitled to receive a bounty of three cents for each sparrow thus killed, to be allowed and paid in the manner hereinafter provided.

2259c. $A m$. $I b .1889$. Sec. 2 Every person applying for such bounty shall take such sparrow, or the head thereof, in lots of not less than ten, to the clerk of the township, village or city within which such sparrow shall have been killed, who shall thereupon decide upon such application, and if satisfied of the correctness of such claim, shall issue a certificate stating the amount of bounty to which such applicant is entitled and deliver the same to said applicant, and shall destroy the heads of such sparrows.

2250d. Am. Ib. 1889. SEc. 3. Such certificate may be presented by the claimant or his agent to the county elerk of the county in which such sparrow or sparrows have been killed, who shall thereupon draw a warrant for the amount on the treasurer of said county, and said treasurer shall, upon presentation of said warrant, pay the same from the general or contingent fund of said county.

GAME AND FISH WARIELE.

2197x. 1887, p. 27, Mar. 15, Act. 28. Sестіо 1. The People of the State of Michigan enact, 'That it shall be the duty of the Governor to appoint some person, a resideut of this state, game and fish warden. Said warden shall hold his office for four years, or until his successor has been appointed and qualified, unless removed for cause by the Governor; he shall receive a salary of twelve hundred dollars per annum, payable monthly, and shall also be reimbursed his actual expenses necessarily incurrred by him while engaged in the performance of his duties, to be paid on the warrant of the auditor general, monthly, on the approval of his vouchers therefor. 
$2197 \mathrm{~s}$. SEC. 2. It shall be the duty of the said game and fish warden to enforce the statutes of this state for the preservation of moose, wapiti, deer, birds and fish, and to enforce all other laws of this state for the protection and propagation of birds, game and fish, now in force, or hereinafter enacted, and to bring or cause to be brought act. ions and proceedings in the name of the people of this state to punish any parties for the violation of said statutes and laws. Such actions and proceedings may be brought in the name of the people, in the like cases. in the same courts, and under the same circumstances as they may now or at any time hereafter be brought by any individual or by the prosecuting attorneys of the several counties under and by virtue of any laws now existing or hereafter enacted.

2197t. SEC. 3. Said warden may make complaint and cause proceedings to be commenced against any person for the violation of any of the laws for the protection or propagation of game or fish without the sanction of the prosecuting attorney of the county in which such proceedings. are commenced, and in such case he shall not be obliged to furnish security for cost.

2197u. SEc. 4. Said game and fish warden shall have the same power to serve criminal process as sheriffs, and shall have the same right as sheriffs, to require aid in executing such process. Said warden may arrest. without warrant, any person caught by him in the act of violating any of the aforesaid laws for the protection or propagation of birds, game or fish, and take such person forthwith before a justice of the peace, or other magistrate having jurisdiction, who shall proceed without delay to hear. try and determine the matter, and the same proceedings shall be had as near as may be, as in other criminal matters triable before a justice of the peace, or other magistrate having jurisdiction. Such arrests may be made on Sunday, in which case the person arrested shall be taken before a justice of the peace, or other magistrate having jurisdiction, and proceeded against as soon as may be, on a week day following the arrest.

2197v. Sec. 5. Said warden shall, in the month of December in each year, file in the office of the auditor general, an account in writing, stating the days and parts of days spent in the discharge of his duty, the kind of service rendered and the places where rendered, and the expenses paid or incurred in the time of the discharge of such duties, which account shall be verified by the oath of said warden stating that the same is correct and true in every particular.

2197w. SEc.6. Said warden shall, at the close of each calendar month. file with the secretary of state a report in writing, and in detail. stating the service performed by him during the last preceding month. including an account of the suits commenced at his instance, as herein provided for, the disposition made of the same, the result of any brought to trial, and the condition of any undisposed of, and any other particulars he may think proper, and no payment for services performed or expenses paid by said warden shall be made until he shall present to the auditor general, in addition to the usual oath of performance and payment, a certificate from the said secretary that he has made the report required by this act. The secretary of state shall cause the monthly reports of said warden, or so much thereof as may be of interest to the public. to be transmitted annually to the legislature when in session.

2197x. SEc. 7. The said game and fish warden shall have power to appoint a deputy or deputies, not exceeding three, in each county, who shall be residents thereof; said deputies shall have the same powers in their respective counties as herein provided for the warden himself. subject to the supervision and control of the warden. Said deputy warden or wardens shall receive such compensation as the board of supervisors of the counties in which such deputy warden or wardens reside may allow and provide for, except in the county of Wayne. where such compensation shall be fixed by the board of county auditors. 


\section{GENERAL LITERATURE.}

Cones. Dr. Elliott. 1890 - Key to North American Birds. Very fully illustrated. This work is very complete and admirable, an excellent manual in my judgment, for either the beginner or advanced student. The complete anatomy. full descriptions, excellent artificial key, and admirable illustrations. make it indispensable to every student of ornithology. The nomenclature and arrangement are not the latest, but an appendix corrects this, in a manner that is very convenient and desirable. Price \$7.50. Estes \& Lauriat. Boston. Mass.

Ridgway, Robert, 1889 - Manual of North American Birds. This is simply a manual, and is very excellent for one who wishes simply to study systematic ornithology. The nomenclature and arrangement are recent. Price \$7.50. J. B. Lippencott. Philadelphia, Pa.

Jordan. Dr. David Starr. 1888 - Manual of the Vertebrates of the Northern United States. This is very brief, but valuable to every zoölogist. This succinct key helps us to identify all vertebrate animals, from fish to mammals, inclusive. It is very satisfactory, considering its size. All three of the above works refer more or less to Michigan birds. Price \$2.50. Jasen MeClurg \& Co., Chicago, Hli.

Davie, Oliver, 1889 - Nests and Eggs of North American Birds. A few illustrations. This work is very full and accurate, and very valuable to one wishing to study the nesting habits of birds. There are many references to Michigan species. Price \$1.75. Hann \& Adair. Columbus. Ohio.

Standard Natural History of the United States, Vol. IV. 'This large work is almost indispensable to the working naturalist. It is to be regretted that its size and cost place it beyond the reach of many. It is fully illustrated and embraces the ornithology of the whole world. It also treats of all other classes of animals, and is very complete. S. E. Cassino \& Co., Boston, Mass.

The Auk. A very excellent monthly magazine, devoted to ornithology; the organ of the American Ornithologists' Union and the suecessor to the Bulletin of the Nuttall Ornithological Club. Its editors and contributors are among the ablest ornithologists in the country or the world. The magazine is a credit to our science and literature. Price 830 a year. L. S. Foster, 35 Pine St., New York City.

The Ornithologist and Oologist. This is a much less pretentious journal than the Auk, but is very interesting and valuable to the student of birds. Like the last mentioned, this contains mueh regarding our. Michigan birds. It is especially valuable to the young ornithologist. Price \$1.00. Frank Blake Wobster Co., Hyde Park, Mass. 
Forest and Stream. This weekly journal is more of at sportsman's paper. but contains much that is helpful to the scientist. Several excellent lists of Michigan birds have appeared in this journal. Price $\$ 4.00$ per year. Forest and Stream Publishing Co, 318 Broadway, New York City.

'The Oölogist. This valuable journal has already passed to its tenth volume. It is more than its name implies as it treats of general ornithology as much as of eggs. It has, like all of the above, many able cóntributors from Michigan. Price 50e per year. Frank H. Lattin, Albion, N. Y. 


\section{BIBIIOGRAPHY.}

*Allen, Herbert, 1880. "Bird Notes from Michigan," Oölogist, Vol. V, No. 10, p. 79. Refers to Bohemian Wax-wing, Rough-legged Hawk, Broad-winged Hawk. Wild Turkey, etc.

Allen, J. A., 1878. "Rare Birds in Michigan," Bull, Nutt. Orn. Club, Vol. IV, p. 123. Statement of Western Meadow Lark and Oregon Snow Bird in Michigan on the authority of Dr. H. A. Atkins.

Allen, J. A., 1879. "Gibbs' List of Birds of Michigan," review of, Bull. Nutt. Orn. Club, Vol. V, p. 110.

Allen, J. A., 1880. "Steere's Birds of Ann Arbor," review of, Bull. Nutt. Orn. Club, Vol. VI, p. 46.

Anonymous, 1880. " Wild Pigeons in Michigan," Scientific American, Vol. 42, pp. 343344. Notes on breeding and migrations, copied from the Detroit Post.

Anonymous, 1887. "The Evening Grosheak at Saginaw, Michigan," Forest and Stream, Vol. XXXIV, p. 143.

Anonymous, 1892. "Capture of a Pelican near Grand Rapids." Ornithologist and Oöl ogist, Vol. XVII, p. 143. Copied from Grand Rapids paper. The bird was exhibited by G. K. Hurlburt.

Atkins, Dr. H. A., 1878. " Rare Birds at Locke," Lansing Republican, Nov. 8, 1878. Two species of Junco reported; "First Capture of Connecticut Warbler," ibid., June 6, 1879 .

Atkins, Dr. H. A., 1879. "Rare Birds in Michigan," Bull. Nutt. Orn. Club, Vol, 1V, No. 2, 1879; "The Snow Bird in Southern Michigan in Summer," ibid., Vol. IV, No. 4, 1879.

Atkins, Dr. H. A. 1879. "The Snowbird, Junco hyemalis, in Southern Michigan," Bull. Nutt. Orn. Club, Vol. IV, p. 238. Taken at Locke, July 8, 1879. Also records that C. W. Gunn took it at Grand Rapids, July 13,1878 .

Atkins, Dr. H. A., 1880. “Orange-crowned Warbler," taken at Locke, Oölogist, Vol. V, p. 72 .

Atkins. Dr. H. A. 1881. "Bird Notes from Michigan." (Ornithologist and Oölogist, Vol. VI, 1881; "Small Green-crested Flycatcher," ibid., Vol. VI, 1881, dates of arrival are griven for +wenty-five consecutive years: "The Whip-poor-will," ibid.. Vol. VI, No. 6. 1881; "Date of Arrival of Scarlet Tanager and Baltimore Oriole for 25 years," ibid., Vol. VI. No. 2. 1881.

Atkins, Dr. H. A. 1881. “Birds of Locke," Oölogist, Vol. V, 1881, No. 12, p. 93. Note

\footnotetext{
* A few of these references I have not been able to verify, and so there may be an occasional error.
} 
is made of Song Sparrow, Jan. 1, and Rad-bellied Nuthatch, Dec. 19. He also notes taking of Song Sparrow two years in January, four in February, and once in March, during 23 consecutive years of observation.

Atkins, Dr. H. A., 1882. "Capture of Chipping Sparrow in Locke, Michigan, in winter (Dec. 19, 1881)," Ingham County Democrat (Mason, Michigan), Jan. 5, 1882. Thought to be the first capture of this bird in Michigan in winter.

Atkins, Dr. H. A., 1882. "Our two Cuckoos breeding in one nest," Ornithologist and Oölogist, Vol. VII, 1882, p. 189; "Tufted Titmouse," ibid., Vol. VII, 1882.

Atkins, Dr. H. A.. 1833. "Carolina Chickadee Taken at Locke." Williamston Enterprise, Nov. 14, 1883; reports a small flock of Western Meadow Larks, Stumella neglecta, at Locke in October, ibid., Oct. 3, 1883.

Atkins, Dr. H. A., 1883. "American Redstart," Onithologist and Oölorist. Vol. 8, p. 31. Gives dates of its arrival at Locke, Michigan, for 26 consecutive years.

A tkins, Dr, H. A., 1883. "Obituary of," The Auk. Vol. I, p. 391.

Atkins, Dr. H. A., 188t. "List of Winter Birds of Locke," Lansing Republican, Jan. 1884. This is a list of December birds and includes the Meadow Lark: "List of Birds in January, ibid. Feb. 14, 1881; "Winter birds of Locke in February," ibid. March 6,1884 .

Atkins, Dr. H. A., 188t. "Sandhill Crane," Ornithologist and Oölogist, Vol, IX, 1884, p. 6. Nest described and the dates of the arrival of the bird given for twenty-seven years.

Atkins, Dr. H. A. 1884. "Winter Birds of Locke, Michigan," Ornithologist and Oölogist Vol. IX. p. 31; "Summer Birds of Locke, Michigan," ibid. p. 43; "Five additions to the avi-fauna of Michigan," ibid. p. 81, discusses Long-tailed Chickadee, Brown-headed Nuthatch, Gray-headed Snowbird, Western Nonpareil and Ground Dove.

Atkins, Dr. H. A., 1885̃, "Summer Birds of Locke, Michigan," Ornithologist and Oölogist, Vol. X, p. 3. Includes eighty-two species; "The Bay-breasted Warbler, at Locke, Michigan," ibid. p. 55; "Obituary Notice of," ibid. p. 120.

Bailey, Prof. L. H., 1873. "Bird Friends of the Pomologist." Report of Michigan Pomological Society, 1873 , p. 127.

Barrows, Walter B., 1889. The English Sparrow (Pusser domesticus) in North America, especially in its Relation to Agriculture. Prepared under the direction of Dr. C. Hart Merriam, Ornithologist of the Department of Agriculture. Bulletin No. 1, United States Department of Agriculture. Division of Feonomic Ornithologr ard Mammalogy. Washington, 1889, p. 405 and map.

Bendire, Chas., 1892. "Passenger Pigeons in Michigan." "Smithsonian Contribution to Knowledge," Vol. XXVIII, p. 133. Gives summary of Mr. Wm. Brewster's researches in Northern Michigan; "Barn Owl, Strix pratincola, at Sault Ste. Marie," ibir. p. 325

Brayton. Alembert W., B. S., M. D. "A Catalogue of the Birds of Indiana, with Keys and Descriptions of the Groups of Greatest Interest to the Horticulturists." Transactions of the Indiana Horticultural Society. 1879, pp. 87 to 165 inclusive.

Boies, A. H., 1875. "Catalogue of the Birds Ascertained to Oceur in Southern Michigan, Together with the Game and Fish Laws of Michigan and Miscellaneous Articles for Sportsmen." A pamphlet published by W. T. B. Schermerhorn. Hudson. Michigan, This is an annotated list of 211 species. 'Lhe list claims to embrace only those species found in the southern portion of the Lower Peninsula. 
Boies, A. H., 1876. "Additions to a Catalogue of Michigan Birds," Rod and Gun, Vol. XII, January 15,1876 , pp. 89 to 93.

Boies, A. H., 1881. " "Stray Notes," A. H. Boies, Hudson, Michigan, "The Auk, Vol. II, pp. 285 to $291 . "$

Boies, A. H., 1889. "Cowbird Living with English Sparrow" Ornithologist and Oölogist, Vol. IX, p. 128.

Brotherton, Wilfred A., 1891. "An Unexpected Fall," Ornithologist and Oölogist, Vol. XVI, p. 28. Refers to Shrike, Cuckoo, Mourning Dove, etc. "The Great Blue Heron," ibid pp. 90 and 91; "A Pair of Pugnacious Jays," ibid, p. 101; "The Rosebreasted Grosbeak in Oakland County, Michigan," ibid., Vol. XVII, p. 131.

Brewster. Wm.. 1888. "The Present State of the Wild Pigeon, Ectopistes migratorius, as a Bird of the United States, with Some Notes on Its Habits," Auk, Vol. VI, Oct. 1889, p. 285. This is an account of a visit to central and northern Michigan in the spring of 1888, and gives the result of his observations on this species.

Brownell, W. C., M. D., 1890. "The Haunts of the Water Thrush," Ornithologist and Oölogist, Vol. XV, pp. 153 and 154.

Brownell, W. C... M. D., 18:1. The least Bittern and Long-billed Marsh Wren at Murl Lake, Ornithologist and Oölogist, Vol. XVI, pp. 21 and 22.

Brownell, W. C., M.D., 1892. "Sandhill Crane in Michigan," Ornithologist and Oölogist, Vol. XVII, p. 156. Reported from Shiawassee county.

Brownell, W. C.. M. D., 1892. "The Color Phenoment of the Little Screech Owl," Ornithologist and Oölogist, Vol. XVII, p. 105.

Ballou, W. H., 1879. "Ornithological Notes Along Detroit River," Oölogist, Vol. III, p. 57 .

Butler, Amos W., 1890. "A Catalogue of the Birds of Indiana." illustrated. This is an annotated list of Indiana birds. It is very full and accurate, and reflects great eredit upon its author and the state of Indiana. It contains 305 species and gives many references to Michigan birds. Transactions Indiana Horticultural Society. 1890. It is also published under separate cover by the author, at Brookville, Ind.

Butler, Amos W., 1892. Notes on Indiana Birds, Proceedings Indiana Academy of Science, 1891, Brookville, Ind., 1892. Notes the occurrence of the Prothonotary Warbler, Protonotaria citrea, in St. Joseph county. Mich.

Butler, Amos W., 1892. "Notes on the Range and Habits of the Carolina Parakeet," The Auk, Vol. IX, pp. 49 and 56 . Mentions a species in the National Museum from Michigan; "Some notes concerning the Evening Grosbeak," ibid, pp. 238-247; "Notes its oceurrence at Kalamazoo. 1869. 1873. 1878. 1579; Grand Rapids. 1869, 1874. 1879, 1887, 1888. 1889), 1890; Paw Paw. 187; Petersburg, 1888, 1889; Alma. 1890; Olivet, 1890; Agricultural College, 1888, 1889; Y psilanti, 1890, and Geddes, 1890.

Butler, Amos W., 1893. "Further Notes on the Evening Grosbeak," The Auk, Vol. $\mathrm{X}, 1893$, pp. 155-157. Notes its occurrence in Washtenaw county in the fall of 1889 , upon the authority of L. W. Watkins.

Cabot, J. E., 1850. "Report of the Birds Collected and observed at Lake Superior," Gould. Kendall it Lincoln, 59 Washington street, Boston, chapter 8. This list embraces sixty-nine species, and contains some rare northern forms.

Collins, W. H., 1875. "Notes on the Breeding Habits of some of the Water Birds of St. Clair Flats, Michigan," Bull. Orn. Club, Vol. V, p. 61. Notes two nests of Aythya americama. one nest of Fulid marila. and occurrence of Fulix affinis, Hydrochelidon lariformis, Larus philadelphia, and the nesting of the last. 
Collins, W. H., 1778. "Notes on the Nesting of the Black Tern," Oölogist, Vol. IV, 1878. Nest reported from St. Clair Flats; "Breeding of Podilymbus podiceps," ibid., Vol. V. p. 19, Sept., 1879, Nest reported from St. Clair Flats, and the eggs and young described: "Pomarine Jager in Detroit," ibid., Vol. V, p. 24, 1879.

Collins, W. H., 1880. "Nesting of the Brant, Foster's and Wilson's Terns and Canvas-backed Duck," Ornithologist and Oölogist, Vol, V, 1880. Six nests found with eight to twelve eggs each. Observations were taken at St. Clair Flats; "Oölogical Notes," ibid. Vol. V. 1880.

Collins, W. H., 1881. "Those Brants," a correction, Ornithologist and Oölogist, Vol. VI. 1881.

Collins, W. H., 1882. "Sea Dove," ibid., Vol. VII, 1882, p.111. A note of its capture in Michigan, Nov, 30, 1881.

Cook, A. J., 1872. "The Bird Friends of the Horticulturist." Report of State Pomological Society, 1872, p. 631 .

Cook, A. J., 1874. " "Birds destroying the Codling Moth." Report State Pomological Society. 1874, p. 159. Special mention is made of the Downy Woodpecker.

Cook, A. J., 1875. "Relation of Birds and Insects," Report of the Michigan State Pomological Society, 1875, p. 428.

Cook, A. J., 1875. "Birds as Insect Destroyers," Report of State Board of Agriculture, 1875. p 277. Special reference is made to birds destroying white grubs and cut worms.

Cook, A. J., 1875. "Robins and Blackbirds," Report State Board of Agriculture, 1875, p. 61. A report of their value in destroying insects, especially white grub and cut worm, is given.

Cooley, Judge T. M., 1855. "A Plea for the Birds." Transactions of the State Agrieuitural Society, 1855, p. 17.

Corris, J. P. M., 1890. "A Series of the Eggs of the Golden-winged Warbler," Ornithologist and Oölogist, Vol. XV, pp. 21 and 22.

Coues, Dr. E., 1871. “Comments on Notes by B. Walker," Detroit, Mich., American Naturalist, 1871, pp. 437 and 438. Refers to Evening Grosbeak and Shore Lark.

Covert, A. B.. 1876. "A Letter of Promise," Forest and Stream, Vol. XI, March 2. 1876, p. 52. This discusses our Michigan birds and the ability of birds to foresee atmospheric changes; "Birds of Lower Michigan," ibid., Vol. XI, 1876, pp. 99, 132, 163, 214, 266, Vol. VII, pp. 147, 164. 276, 318. 354 and 402. This list embraces 244 species with copious annotations.

Covert, A. B., 1876. "Nesting of the Solitary or Wood Tattler." Oölogist, Vol. II, 1876.

Covert, A. B., 1877. "Notes on Michigan Birds," Forest and Stream, Vol. V1I, 1877. Covert, A. B., 1877. "That Hybrid Owl," Oölogist, Vol. III, p. 97, 1877. Bubo virginianus and Bubo virginianus arcticus, both from Michigan, the latter from "north woods."

Covert, A. B. 1878. "Nesting of the Red-breasted Grosbeak," Oölogist, Vol. III, p. 50. Copied from Forest and Stream.

Covert. A. B., 1878. "Nesting of the Large-billed Water Thrush." The Oölogist, Vol. IV, pp. 10 and 11, April, 1878.

Covert, A. B., 1881. "Annotated List of Birds and Mammals of Washtenaw County Michigan," History of Washtenaw county, Michigan. 1881. This is a valuable addition to the various lists published in the state and embraces 252 species. 
Covert, A. B., 18s1. "The Enemies of Game Birds," Chicago Field, Vol. XVII. Dec. 8, 1881.

Daggett, Frank S., 1890. "Birds" Eggs on Isle Royal, Lake Superior," Ornithologist and Oölogist, Vol. XV, pp. 99 and 100. Refers to Gulls, Warblers. Hawks and Loons.

Davidson, W. A., 1892. "Nesting of Cardinal Grosbeak and Cerulean Warbler, near Detroit," Ornithologist and Oölogist, Vol. XVII, pp. 111 and 137; "Cerulean Warbler," ibic.. p. 137. Breeding near Detroit.

Dewey, L. H., 1888. "Birds of the Pine Woor in Northern Michigan," Report of State Board of Agriculture. 1888, p. 187. Mention is made of birds seen in a trip across the state through the pine forests.

Durfee, E. W., 1890. "Nesting of the Short-billed Marsh Wren," Ornithologist and Oölogist, Vol. XV, p. 156.

Dwight, Jonathan, Jr.. 1890. "The Horned Larks of North America," The Auk, Vol. VII, pp. 135 and 159. Notes specimens from Ann Arbor and Cadillac and breeding from the last place.

Eddy, N. A., 1882. "Black-backed Woodpecker in Michigan," Ornithologist and Ö̈logist, Vol. VII, p. 143, 1882; "Black-backed Woodpecker in Michigan," Ornithologist and Oölogist, Vol. VII, No. 181, 1882, p. 143; "Michigan Notes on Birds," ibid., Vol. IX, 1883, p. 4 .

Eddy, N. A., 188t. "Michigan Notes," Ornithologist and Oölogist, Vol. IX, 1884, pp. 4 and 5. Notes on Bald Eagle, Carolina Rail, Herring Gull, Bonaparte's Gull, Common Tern, Black-backed Woodpecker, and Surf Duck; "Bird Notes from Bay City," ibid. p. 41 .

Fluher, Rev. Chas., 1886. "Ruthless Destruction of Birds," Report State Horticultural Society, 1856, p. 355. A record is given of the tremendous destruction of birds to be used ornamentally and suggestions given to prevent it.

Forbes. Prof. S. A., 188L. " Birds and Canker Worms," report of State Horticultural Society, 1881, p. 203. This valuable article records investigations of many of our most common birds which were found feeding upon the Canker Worm. Per cent of insect food is given in each case.

Fox, Rer. Chas., 185̄. "Published List of the Birds of Michigan." Said to include 212 species. I have been unable to secure this list.

Gibbs, Dr. Morris, 1875. "Our Northern Mockingbird, Catbird," Galeoscoptes carolinensis (Linn.) Caban, Kalamazoo Telegraph, July, 1875. This is a simple biography. Gibbs. Dr. Morris, 1876. "Tenacity of Life in Animals," Kalamazoo Gazette, 1876. Refers largely to birds.

Gibbs, Dr. Morris, 1877. "Voyage on the Kalamazoo Kiver" from Kalamazoo to the Mouth," Kalamazoo Telegraph, Aug. 24 and 26,1877 . A record of the birds and mammals was kept by Gibbs and Tuthill; "Breeding Habits of Myiodioctes mitratus" (Gmel.) Aud. Naturalist and Fancier, Vol. I, No. 8, p. 31, 1877. The above paper was published monthly by C. W. Gunn, Grand Rapids, Mich.,from 1877 to 1879.

Gibbs, Dr. Morris, 1878. "Breeding Habits of the Golden-winged Warbler," Helminthophaga chrysoptera (Linn.) Baird, Naturalist and Fancier, Vol. II, No. 3; "A list of the Warbler taken in the State." ibid., Vol. II, No. 2. This gives 28 species with notes.

Gibbs, Dr. Morris, 1879. "Annotated List of Birds of Michigan," Bull. of the U. S. Geographical and Geological Survey of the Territories. Vol. V, No 3, Art. XXIV, pp. 481 to 497 inclusive. This embraces 309 species, states whether each species is rare or com- 
mon, whether it breeds or is a transient or migrant and where it is found. It is, considering its early date, very accurate and complete.

Gibbs, Dr. Morris, 1879. “A New Bird," Grand Rapids Democrat, June 1, 1879. This article treated of a supposed new bird, Helminthophaga gunnii Gibbs. It proved to be Helminthophaga leucobronchialis.

Gibbs, Dr. Morris, 1879. "Breeding Habits of the (ireat Blue Heron, Ardea hero" dius Linn." Naturalist and Fancier, Vol. III, No. 1, 1879. This records a visit to a large herony; "The Evening Grosbeak," ibid., Feb. 1879.

こGibbs. Dr. Morris. 1879.コ"Rambles of a Naturalist." Kalamazoo Telegraph, May, 1879. This diseribes several species including Conuecticut Warbler and Olive-sided Flycatcher, and gives the breeding habits of several rare species.

Gibbs, Dr. Morris. 1883. "Hibernation of Swallows," Portland (Me.) Transcript, July, 1883.

こGibbs, Dr. Morris. 1883 and 1884. "Ornithology of Michigan," Michigan School Moderator 1883-4. Several articles commencing Vol. IV, No. 11, Nov. 15, 1883, and extending to Vol. V, Feb. 2, 1884.

Gibbs, Dr. Morris, 1884. "The genus Empidonax," the American Field, Vol. XXI, No. 10, March 8, 1884, p 232. This is a description of the four small Flycatchers of Michigan. The paper was rearl before the Ridgway Ornithological Club at Chicago.

Gibbs, Dr. Morris, 1884. "Michigan Notes," The Ornithologist and Oölogist, Vol. IX, 1881, pp. 66, 67, 68. Discusses nesting habits of Hawks, Owls, Thrushes, and other Michigan birds; "Song of the Golden-crowned Thrush," ibid., Vol. IX, p. 191.

Gibbs, Dr. Morris, 1884. "The Game Birds as Insect Destroyers." Many species of birds of economic importance to man are listed. This paper was read before the Michigan Sportsmen's Association and published in the Transactions of that society.

Gibbs, Dr. Morris, 1885. "The Genus Helminthophaga," American Field, Vol. XXIII, 1885, Jan. 3d, p. 8. This paper was read before the Ridgway Ornithological Club of Chicago, and describes six Michigan species; " The Family Picida in Michi gan," ibid., Vol. XXIII, p. 415. A review of the nine species recorded from the state; “The Genus Vireo in Michigan," ibid., Vol. XXII, p. 200. The six species that occur in the state are reviewed; "Nomenclature of Limicolæ of Michigan with Annotations." Read before the Michigan Sportsmen's Association of Feh. 18. 185\%, and published in the Transactions of that society.

Gibbs, Dr. Morris, 1885. "A Catalogue of the Birds of Kalamazoo County," Ornithologist and Oölogist, Vol. X. pp. 54, 68, 86, 118, 133, 149, 166 and 189.

Gibbs, Dr. Morris, 1885. “The Birds of Michigan," Forest and Stream, Vol. XXIV, pp. 5, 26, 44, 65, 104, 125, 184, 267, 288, 307 and 387; ibid., Vol. XXV, pp. 4 and 304 ; ibid. Vol. XXVI, p. 305; ibid., Vol. XXVII, pp. 123 and 223. This list has elaborate annotations and continues irregularly to Oct. $14,1886$.

Gibbs, Dr. Morris, 1886. "Kalamazoo County (Michigan) Notes," Ornithologist and Oölogist, Vol. XII, p. 22. Many northern birds were observed in December with a suggestion that this may indicate a severe winter; "I he Swallows Have Come," ibid., p. 72. A poem; "How Birds Breathe," ibid., Vol. XIII, pp. 97 and 98. Note is made of a peculiar instance illustrating abnormal conditions.

Gibbs, Dr. Morris, 1887. "Kalamazoo County Notes," Ornithologist and Oölogist, Feb., 1887. Discusses the ability of birds to endure severe weather.

Gibbs, Dr. Morris, 1888, "Caprimulgida of Michigan," Geological Gazette. July, 1888 . 
Gibbs, Dr. Morris, 1888. "Family Rallida in Michigan," Oölogist, Vol. IV, pp. 85 to 88; "The Great Northern Diver." ibid., July, 1888.

Gibbs, Dr. Morris, 1888. "Birds' Songs," Oölogist Exchange, Sept., 1888; "The Hooded Warbler," ibid., 1888.

Gibbs, Dr. Morris, 1888. "Foot Movements in Birds," Hawkeye, Ornithologist and Oölogist, July, 1888.

Gibbs, Dr. Morris. 1888. "The Effects of Anaesthetics," Agassiz Record, June, 1888.

Refers to birds.

Gibbs, Dr. Morris, 1889. “Winter Birds of Kalamazoo County," Oölogist, Oct., 1889, pp. 187-189. Includes 68 species; "Raptores of Michigan." ()ölogist, Vol. VI. 1889. pp. 67 to 69 .

Gibbs. Dr. Morris, 1889. "The American Bittern," Ornithologist and Oölogist, Vol. XIV, Aug., 1889, p. 120.

Gibbs, Dr. Morris, 1889. "The Crossbills of Michigan," Old Curiosity Shop, Feb, 1889; "The Mourning Warbler in Michigan," ibid, Feb. and March. 1889.

Gibbs, Dr. Morris, 1890. "A Very Peculiar Bird." Ornithologist and Oölogist, Jan., 1890. The habits and character of the Cowbird are described.

Gibbs, Dr. Morris. 1890. "Game Birds of Michigan." Fish and (iame Warden, Aug. to Nov. 1890.

Gibbs, Dr. Morris, 1890. "Yellow Rail," Oölogist, Nov. 1890. Described as a rare Michigan bird.

Gibbs, Dr. Morris, 1890. "Snipe and Snipe Shooting." Shooting and Fishing, (Boston), Sept. 11. 1890. Discusses the nesting and feeding of Snipes; ". I Wild Pigeon Hunt," ibid., Nov. 20, 1890. The extinction of the pigeon is discussed.

Gibbs, Dr. Morris. 1890. "The White Peliean taken in Michigan," Forest and Stream, Vol. XXXVII, p. 296.

Gibbs, Dr. Morris, 1891. "The American Cuckoos," Nature's Realm, April, 1891. Nesting habits of the Woodeock deseribed.

Gibbs, Dr. Morris, 1892. "The Bird in its Nest," Science, Aug. 19, 1892; "Acorn Eating Birds." ibid., Sept. 2: " The Effects of ('ivilization on our Birds," ibid., Sept. 30; "Birds that sing in the Night," ibid., Dec. 2; "The Humming Bird's Food," ibid. Oct. 28.

Gibbs. Dr. Morris, 1892. "Bird Life in a City Yard." Forest and Stream, Oct. 25, 1892. Of a list of one hundred and thirty-four species of birds, nineteen were found nesting in a city lot, five by twelve rods in size; "A Habit of the Robin," ibid., Oct. 20, 1892.

Giblos, Dr. Morris, 1892. "A Flight of Hawks," American Field, Oct. 8, 1892; "The Night Hawk." ibid.. Oct. 15. 1892.

Gibbs, Dr. Morris. 189:. "The Kingfisher. The Angler's Companion," American Angler, Juiy. 1892.

Gibbs. Dr. Morris, 1892. "The Electric Destroyer," Detroit Free Press. Sept. 15, 1892. Discusses killing of birds and insects about electric lights.

Gibbs, Dr. Morris, 18933. “The American Osprey," Oölogist, Feb. 1893. "Michigan Herons," ibid.. March, 1893: seven species described and their mesting habits given.

Gibbs, Dr. Morris, 1893. "The Arrangements and Number of Eggs in the Nest." Science, Vol. XXI, pp. 148. The nesting habits of many Michigan bircls are referred to.

Gibbs, Dr. Morris, 1893. "The Pine (rrosbeak in Michigan," Ornithologist and Oölogist. Vol. XVIII. 1893, pp. 39 to 41. 
Gibbs, Dr. Morris, 1893. "Birds Which Nest in Cavities and Burrows:" illustrated. Speaks of many species: Swallows, Woodpecker, Kingfisher, Blackbird, and many rare examples. Scientific American, Vol. IV, p. 8, 1893.

Gunn, Chas. W., 1876. "The Wild Pigeon, Ectopistes migratorius," The Oölogist, Vol. II, 1876.

Gunn, Chas. W., 1877. "The Red-Poll, Aegiothus linaria Cab., and Snow Bunting, Plectrophanes nivalis Meyer," Naturalist and Fancier, Vol. I, No. 1, 1877; "The Evening Grosbeak, Hesperiphona vespertina Bp.," ibid., Vol. I, 1877; "The Pine Grosbeak, I'inicola enucleator Cab.." ibid., Vol. I. No. 3. 1877: "Winter Notes on the Birds of Kent County, Michigan." ibid., Vol. I, 1877. Thirty-six species with annotations; "Arrival of Birds at Grand Rapids," ibid., Vol. I, 1877; "Nesting Habits of the Shore Lark, Eremophila alpestris Boie.," ibid., Vol. I. 1877; "Birds in Winter," ibid., Vol. I, 1877; "The Canada Goose," ibid.. Vol. I, 1877.

Gunn, Chas. W., 1878. "Items from Michigan," Western Oölogist (Wis.). Vol. I, No. 5, 1878. Notes on birds; "Nesting Habits of Warblers," ibid., Vol. I, 1878. Describes the nests and eggs of Black-throated Blue, and Golden-winged Warblers; "Notes on the Wild Pigeon." ibid., Vol. I, 1878.

Gunn, Chas. W., 1878. “The Western Loggerhead, White-rumped Shrike, Collyrio excubitorides," Naturalist and Fancier, Vol. II, 1878; "The Evening Grosbeak," Hesperiphona vespertina, Bp.," ibid., Vol. III, $187 t$.

Gunn, Chas. W., 1879. “Rare Birds of Michigan," Bull. Nutt. Orn. Club, Vol, IV, p. 186. Notes captures of Connecticut Warbler in Michigan.

Gunn, Chas W., 1879. "Rare Birds in Michigan," Bulletin Nutt. Orn. Club, Vol. IV, 1879.

Gunn, Chas. W., 1881. "Woodpeckers of Michigan," Agricultural World (Grand Rapids), Vol. XIV, 1881. An annotated list; "Notes on the Winter Birds of Kent County. Michigan," ibid., Vol. IV, 1881. This excellent list is a marked improvement on the list of 1877; "Additional Notes on the Winter Birds of Kent County, Michigan," ibid,, Vol. IV, 1881.

Gunn, Chas. W., 1881. "Arrivals," Ornithologist and Oölogist, Vol. VI, 1881. Embraces notes on spring migrants.

Gunn, Chas. W., 1886. Obituary notice of, Ornithologist and Oölogist, Vol. XI, p. 73. Hatch, Dr. P. L., 1890. "American Coot, Breeds at St. Clair Flats," Notes on Birds of Minnesota. 1892. p. 162.

Hatch, Dr. P. L.. 1890. "Great Gray Owl," "Notes on Birds of Minnesota," 1590, p. 211. Its habitat in Michigan is noted.

Hazelwood, J. H. 1890. "Evening Grosbeak in Michigan," Ornithologist and Oölogist, Vol. XV, p. 96. Records its capture at Fort Gratiot, May 17, 1890.

Hewett, Alexander, 1880. "Birds Should be Fostered." Report State Pomological Society, 1880, p. 4 .

Hollister, Geo. C. 1886. "Albino Robin at Grand Rapids." Ornithologist and Oölogist, Vol. XI, p. 118.

Hughes, D. Darwin, 1869. " Birds Calhoun County." Marshall Democrat Expounder, 1869. This embraces 179 species; "The Bobolink," ibid., May 5, 1870; "The Wild Turkey," Detroit Free Press, Jan. 24, 1870; "The Sora Rail," ibid.. March 16, 1870; "The Different Species of the Plover Family," ibid., Apr. 3. 1870; "The Ruffed Grouse." ibid., Oct. 7, 1870; "Song Birds of Michigan," ibid.. Feb. 12, 1871; “The Robin, Bluebird and Catbird," ibid.. Feb. 19, 1871; "The Pinnated Grouse or Prairie Chicken, 
Cupidonia cupido."ibid., March 24, 1871. The following species were also described by Mr. Hughes in the Free Press for 1871, special date unknown: The American Quail, Field Sparrow. the smaller Thrushes. Brown Thrush. Wilson's Snipe. American Woodcock, Wood Thrush. and Song Sparrow. This whole series of articles is very excellent.

Hughes. D. Darwin, 1870. "The Wild Turkey. Its Origin and Habits," The Moderator (Michigan school paper. published at Grand Rapids). Vol. IV. No. 19, p. 373. This is a reprint of article in Free Press for Jan. 24. 1870.

Hughes, D. Darwin, 1872. "Michigan Birds, Their Relation to Agriculture." Report of the Michigan Pomological Society, 1872, p. 442. 'This discusses our bird friends and includes the Hawks and others which are often condemned.

Hughes, Walter H, 1871. "Arrival and Departure of the Snow Bunting, Plectrophanes nivalis (Linn.) Meyers, from 1867 to 1871." Naturalist and Fancier (Grand Rapids), Vol. 1, No. 11, 1877. Fxtract from the notes of his father, Hon. D. D. Hughes; "Chrysomitris tristis" Bp., ibid.. Vol. II, No. 1, 1878; "The Michigan Plover," ibid., Vol. II. No. 3, 1878, a reprint of an article by Hon. D. D. Hughes.

Hughes, Walter H.. 1878. "Birds of Michigan." Valley Naturalist (St. Louis, Mo.), Vol I, 1878, pp. 11, 14, 15, 34 and 35. This is an annotated list.

Judson, R. F., 1892. "Brief Notes," Ornithologist and Oölogist, Vol. XVII, p. 9. Notes Golden Eagle taken in Kalamazoo, Michigan, Jan. 1, 1892.

K. D. II.. 1886. "The Bald Fagle at Sturgis, Michigan," Ornithologist and Oölogist Vol. IX, p. 75.

Kneeland, Dr. S. Jr.. 18:5i. "Birds of Keweenaw Point," Boston Society of Natural History. Vol. VI. 1857, pp, 231 to 241 inclusive. This list was made as the result of one year's study during a residence at Portage Lake and is undoubtedly very accurate and reliable. It includes 147 species.

Kennicott. R., 1861. A Catalogue of the Trowbridge Collection of Natural History in Michigan University Museum." Pamphlet of thirty-two pages published by University at Ann Arbor, 1861.

Langille, Rev. J. H. 1856. "Nidification of Birds on the St. Clair Flats," Bull. Buf falo Society of Natural Sciences, Vol. V, No. 1.. 1886, pp. 33 to 39. Treats chiefly of water birds; "American Coot, Fulica Americana," Our Birds and Their Haunts, pp. 405 and 406. Gives breeding habitat along the great lakes, and says it is the characteristic bird of the St. Clair Flats.

Lawrence, Robt. B. "Brant in Michigan," Forest and Stream, Vol. 32, p. 316.

Lockwood, E. A., 1891. "Snowy Owls and Swans taken at South Haven." Ten owls and two swans taken in December. American Field, Vol. XXVII.

Lucius, E. Torrey, 1883. " The English Sparrow." Agricultural World, Grand Rapids. Vol. IX, No. 4.

MeBride, Herbert IT.. 1893. Letter. (Ornithologist and Oölogist, Vol. XXIII. 1893. p. 47. Notes breeding of Rose-breasted Grosbeak in Berrien county, Mich.

Maris, Willard L., 1891. "The Rose-breasted Grosbeak in Washtenaw county, Oölogist, Vol. XVI, p. 106.

Merriam, Ir. C. Hart. 1883. "Kirtland's Warbler from the Straits of Mackinaw." The Auk, Vol. I, p. 376 . Mentions several birds received from Wm. Marshall. keeper of lightnouse at Spectacle Reef. Michigan. killed night of May 21, 1883. Among them was a male. Kirtland's Warbler.

Miles, T)r. M.. 186i1. " ('atalogue of Birds of Michigan," ('eological Survey of Michi- 
gan, pp. 2.2 to 232 inclusive. There are 203 spercies embracer in this list, which illustrates the characteristic accuracy of its author.

Milliken, W. E.. 1892. "Nesting of a Chimney Swift in a Freight Car." Ornithologist and Oologist. Vol. XVII, p. 15); "The Rose-breasted (irosheak in Michigan." Vol. XVII, p. 152. Reported quite common in Kent county.

Mills, M. B., 1891. Set of ten eggs from White-breasted Nuthatch, taken at Macon, Michigan," Ornithologist and Oölogist, Vol. XVI, p. 157.

M., 1867. "Nesting of Pigeons at Shelby, Michigan," Forest and Stream, Vol. XIV, pp. 231-232. Describes a pigeon roost.

Moseley, E. L., 1881. "Notes on Winter Birds of Michigan," Forest and Stream, Vol. XXVIII, p. 4. Six species are mentioned.

Moseley, E. L., 1885. "Winter Woodpeckers of Michigan," Forest and Stream, Vol. XXXII, p. 63.

Moseley, E. L.. 1857. "List of Michigan Birds in the Museum of the Kent Scientitic Institute. Grand Rapids. Michigan." This list embraces 231 species. but not all are Michigan birds. This is a pamphlet of 32 pages and was published by the Democrat Company of Grand Rapids.

Nichols, Jason E., 1882. " Black-backed Three-tued Woodpecker in Michigan." Ornithologist and Oölogist, Vol. VI, 1882.

Oldfield, W. A., 1891. "Breeding of Rose-breasted (irosheak and Red-backed Sandpiper in Sanilac County, Michigan," Ornithologist and Oölogist, Vol. XVI, p. 144.

Purdie, H. A., 1879. "Record and Additional Specimens of the White-throated Warbler," Bull. Nutt. Orn. Club, Vol. IV, No. 3, 1879; "Another Kirtland's Warbler, Dendroica kirtlandi." Mentions two of the nine specimens then known as from Michigan, having been taken by Adolphe B. Covert, ibid., p. 105.

Purdy, J. B.. 1889. "Nesting of the Barred Owl and (ireat Horned Owl at Piymouth, Michigan," Ornithologist and Oölogist. Vol. XIV. p. 54; "C'urious Nesting Traits of Birds," ibid., p. 92; "Nests that Perished in the Storm," ibid., p. 110.

Purdy, J. B., 1890. "Horned or Prairie Horned Lark. Which is it?" Ornithologist and Oölogist, Vol. XV, pp. 138 and 139.

Purdy. J. B., 1891. "Late Nesting of the Wond Pewee." Ornithologist and Oölogist. Vol. XVI, p. 28; " Nesting of the Bob White, August 30, 1891," ibid., p. 157.

Purdy, J. B., 1892. "Late Nesting of the Great Horned Owl," Ornithologist and Oölogist, Vol. XVII, p. 57. Nest found March 20, 1892.

Purdy, James B., 1893. " "Domestication of the Canada Goose," Ornithologist and Oölogist, Vol. XVIII, 1893, pp. 4-5.

Raeder, S., 1891. "Correspondence from Ornithologist and Oölogist," Vol. XVI, p. 64. Records taking 21 sets of eggs of Cardinal in Ohio, in 1885; also notes food habits of the crow. A crow darted down and carried off a young chicken.

Reed, Leon, 1886. "Supposed Breeding of the Barred Owl at White Pigeon, Michi. gan," Ornithologist and Oölogist, Vol. XI, p. 100.

Ridgway, Robt., 1879. "Note on Helminthophaga gunnii Gibhs," 13ull. Nutt. Orn.. Vol. IV, No. 4, 1879.

Ridgway, Dr. Robert, 1883. "Helminthophila leucobronchialis," The Auk. Vol. I, pp. 3.9 and 363. Notes a specimen taken by Gunn, Ottawa county, May 25. 1579; "Another Kirtland's Warbler from Michigan," ibid., p. 389. Specimen from collection of N. Y. Greene, Battle Creek, Michigan, May 11, 1883.

Ridgway, Dr. Robert. 1889. "Natural History Survey of Illinois," State Laboratory 
of Natural History, S. A. Forbes, director: Descriptive Catalogue. Springfield. Ill., 1889, illustrated. Refers to many Michigan birds.

Sager, Dr. Abr., 1839. Catalogue of Michigan Birds, by Dr. Abr. Sager, Michigan House Documents, 1839. pp. 412 to 417 inclusive. This catalogue embraces 164 species. This list was evidently prepared with great eare and is without doubt very reliable.

Satterlee, Prof. James, 1877. "Our Friends, the Birds," Report of Michigan Pomological Society, 1887. p. 115. This article discusses birds in relation to their economic importance.

Satterlee. Prof. James, 1886. "The Cherry Bird Condemned," State Horticultural Society, 1886. p. 97.

Saunders, Prof. Wm., 1883. "Condemns the Robin, Cherry Bird and English Sparrow," Report of Michigan Horticultural Society, 1883, p. 164.

Schoolcraft, Henry R., 1834. "A Supposed New Bird," Historical and Scientific Sketches of Michigan. Discovered in Michigan in the forests at the foot of Lake Superior. The bird was identified by the New York Scientific Association as the Evening Grosbeak, Hesperiphonu vespertina (Coop.) Bp.

Smith, W. A., 1885. "The Birds Our Friends," Report of State Horticultural Society, 1885 , p. 249 .

Spicer, Samuel, 1889. "Notes from Goodrich, Genesee County, Michigan," Ornithologist and Oölogist, Vol. XIV, p. 43. Notes some rare birds. Robin building in a barn, and nest of Goldfinch taken Sept. 28.

Steere, Dr. J. B., 1880. List of Birds of Michigan, Report of State Pomological Society, 1880, pp. 115 to 124 inclusive. The birds are classified according to time of appearance into summer sojourners, winter residents. migrants or transients, and those that live here throughout the year. The list embraces 265 species.

Steere, Dr. J. B.. 1880. "Migration of Birds," Report of State Pomological Society, 1880, p. 115. This article divides birds into groups, as to time of residence in the State and embraces a list of 265 species.

Steere, Dr. J. B., 1880. "List of the Mammals and Birds of Ann Arbor and Vicinity," local paper, Ann Arbor, Michigan. Annotated list of 111 species.

Strang, J. J., 1855. "Natural History of Beaver Islands, Michigan:" ninth annual report Smithsonian Institution (1854), 1855, pp. 282 to 288 . A brief mention of three lines is made of birds.

Sudworth, Geo. B., 1878. "Polioptila cærulea (Linn.) Scl.," Naturalist and Fancier, (Grand Rapids), Vol. II, No. 3, 1878.

Swales, B. H., 1891. "Notes on Birds at Detroit," Ornithologist and Oölogist, Vol. XVI, p. 144. Nests found of Red-headed Woodpecker and Woodcock, the former with eight eggs, the latter with four; "Nesting Notes in the Vicinity of Detroit," ibid., pp. 148-9. Dates and nesting habits of Michigan birds; "Notes of the Season," ibid., p. 159.

Stvales. B. H., 1892. "Brief Notes," Ornithologist and Oölogist, Vol. XVII, p. 75 Gives notes of the winter; "Rose-breasted Grosbeak in Wayne County," ibid., p. 64. "American Long-eared Owl Breeding in Wayne County, Michigan," ibid., p. 75; "Brief Notes," ibid,, p. 79; Bald Eagle at Detroit April 4, and Eggrs of Red-shouldered Hawk taken April 13, "Nesting of Virginia Rail at St. Clair Flats," ibid., p. 103; "Nesting. of Phoebe." ibid., p. 111: "Albino Eggs of the Long-billed Marsh Wren," ibid., p. 121: "Nesting of the Field Sparrow in Michigan. found Nesting A ugust 2," ibid., p. 159; "Notes on Tame Red-shouldered Hawk," ibid., p. 159. 
Trombley, Jerome, 1882. "Swallow-tailed Kite taken in Southern Michigan," Bull. Nutt. Orn. Club, Vol. VII, p. 250. Notes a male and female near Petersburg, June 19, $188^{2}$.

Wade, Joseph M., 1880. "Orange-crowned Warbler," Oölogist, Vol.V, 1880. Note of eapture in Michigan.

Washburn, F. L. "Recent Captures of Kirtland's Warbler in Michigan and Other Notes," The Auk, Vol. VI, pp. 279 to 280.

Waters, Dudley E., 1883. "The English Sparrow. Passer domesticus"" Agricultural World (Grand Rapids), Vol. IX, No. 4.

Weed. Prof. C. M.. 1883. " Food Habits of Young Birds," Report of the State Board of Agriculture 1883, p. 439. This is a part of a thesis for degree of Master of Science and shows the value of birds as insect destroyers.

Weed, Prof. Clarence M.. 1884. "The Food Relations of Birds, Frogs and Toads," Report Michigan Horticultural Society, 1884, p. 98. This gives the percentage of insect food of many young birds, determined by actual dissection. Embraced in thesis for the degree of Master of Seience.

Wolcott, Robt. H.. 1884. "Notes from Grand Rapids, Michigan," Ornithologist and Oölogist, Vol. IX. p. 62. Refers to early spring birds.

Wood, A.H.. 1884. "The Black-backed Woodpecker," (')nithologist and Oölogist, Vol. IX, p. 62. Species noted 30 miles north of Mackinaw.

White, S. E.. 1890. "Brown Creeper at Grand Rapids. Michigan," Ornithologist and Oollogist Vol. XV. pp. 101-102; "Favors the Old Names," ibid., p. 137; "Two Days in the Field," ibid., pp. 173-174. Notes on the birds of Mackinac Island.

White, S. E. 1891. "The Picida of Michigan," Ornithologist and Oologist XVI, pp. 56-59; "Stupid Bird Laws of Michigan." ibid., p. 92; "A Pleasant Disappointment," ibid., pp. 100-101. An account of a visit to a heronry and other bird notes; "Turkey" Buzzard Breeding in Michigan." ibid.. 1. 141. Notes the breeding of this and other species along the Kalamazoo river; "Winter Birds with Dates," ibid., p. 149.

White. S. E., 1892. "The Olive-backed Thrush." Ornithologist and Oölogist, Vol. XVII. pp. 111-115. Notes from Fent county and Vackinac Island. 


\title{
BIRDS OF MICHIGAN.
}

\author{
Orner PYíngodes. Diving Birds.
}

Suborder PODICIPEDES. Grebes.

\author{
Family PंODicipid E. Grebes; Hell-Divers.
}

These curious birds are mostly confined to the water and are great divers said to dodge even the rifle ball.

\section{GENOS ACHMOPHORT'S COUE.}

1-1-(8+5). Eehmophoras occidentalis (Lawr.). Western Grebe.

Very rare; probably accidental; one specimen killed near Lansing and now in the collection of Mr. C. H. Davis; one specimen reported in catalogue of "Kent Scientific Institute" by E. L. Mosley; included in "Butler's Birds of Indiana."

Genus COLYMBUS Lins.

2-2-(817). Colymbus holbollii?(Reinh.). Red-Necked Greib; Holball's Grebe.

Very rare; migrant; we have one from Saginaw bay; "one taken by Prof. Smith at Hillsdale, in the spring of 1890, and now in the Hillsdale College museum" (F. M. Faleoner); taken by S. E. White off Mackinac Island; "taker orcasionally at Sault Ste. Marie" (C. S. Osborn). This species is included in the list of Fox and in that of Dr. A. Sager of 1839.

\section{3-3-(848). Colymbus auritus Linn. Horned Greme.}

Common throughout the state; "one taken Feb. 26, 1892, snow bound in Pittsford, township, Hillsdale county " (A. H. Boies). Fall and spring; migrant; oceasional in sum mer; "northern U. S." (Jordan); "Iron Mountain, May 18, 1890" (E. E. Brewster); "Ke. weenaw Point." (Kneeland); breeds: nests in May, on bogs in marshes; "breeds in Wayne county" (B. W. Swales); a fine male was ${ }_{z}^{*}$ taken by J. B. Purdy at Plymouth; "rare transient in Kalamazoo county in spring and autumn" (Dr. M. Gihbs): "rivers of Mich. igan" (Darie's Nests and Equs of North American Birds, p. 3); eggs, tive to nine, immac ulate, yellowish, smooth; "breeds among the lakes and marshes of northern Indiana in considerable numbers" (Butler's Birds of Indiana). 
Genus PODIlyMbUS Less,

1-6-(S52). Podilymbus podiceps (Linn.). *Pied-billed Grebe; Carotina Grebe;

Hell-diver; Water-wituh: Dipper; Didapper; Dabchiok.

Very common "throughout the state and easily shot by the skillful hunter" (A. H. Boies); A pril till fall; "Monroe county" (Jerome Trombley); "Mackinac Island" (S. E. White); "common at Iron Mountain, Dickinson county," (E. E. Brewster); "Keweenaw Point" (Kneeland); breeds; nests as in last species; "found breeding on St. Clair Flats" (W. H. Collins, Oölogist, Vol. V. p. 19); "Geo. Sprague, of Kalamazoo, secured thirty. two eggs in a half day, about ponds and lakes" (Dr. M. Gibbs); eggs, five to nine, rough, dirty yellowish white. The nest of this species often floats. This queer tailless bird is the cause of many stories told by hunters. They report that it will dodge a builet as the most skillful hunter seldom takes one. It certainly might and generally would dive even after receiving a mortal wound. Prof. James Satterlee, Greenville, writes me: "This comes from the habit of diving so quickly after the flash of the gun. I shot five in one day with my rifle." Geo. D. Sones writes: "They dive at sight of Hash, and so escape the bullet." as he has actually observed many times.

\section{Suborder CEPPHi. Loons and Auks.}

FAMILY URINATORIDA. LOONS.

These are pre-eminent water birds, noted for swimming and diving.

(iENUS URINATOR ('UV.

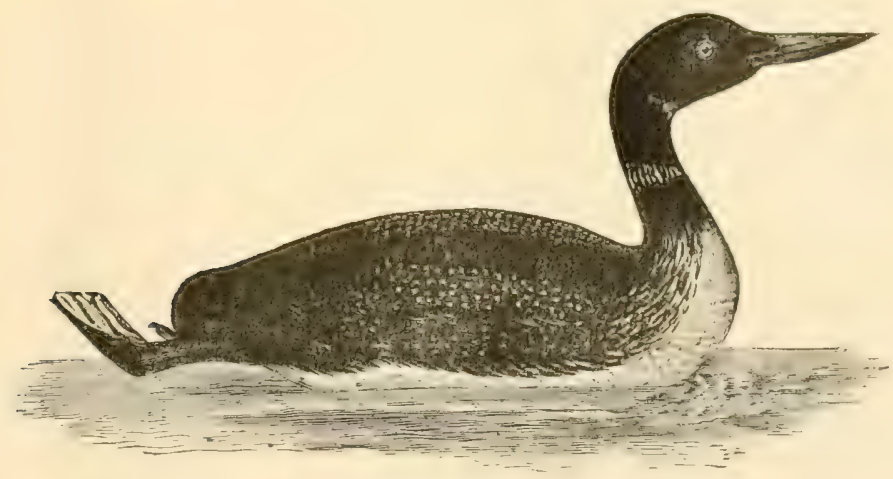

Loon.

;-7 (840). Urinator imber (Gunn.). *Loon; Great Northern Diver.

Very abundant in spring, summer and autumn; throughout the state; "Grand Traverse Co." (Dr. M. L. Leach); "nests have been found in Washtenaw Co. on muskrat houses about marshy lakes," (L. W. Watkins); "Common on Lake Erie and Raisin River" (Jerome Trombley); "Mackinac Island" (S. E. White); "Common at Iron Mountain " (E. E. Brewster); " Keweenaw Point" (Kneeland); breeds plenteously; nests in May, in marshes, on large masses of grass, sedges, ete; eggs two, very rarely three. elongate, olive brown or drab. spotted with darker, often almost black markings; seen

* II apecies starred, are reported from Locke, Ingham County, by the late Dr. H. A. Atkins. 
in winter; "will carry their young on their backs, even when flying from one lake to another for two miles" (A. H. Whitehead). Dr. Atkins took several of these birds in March and April. I have taken them, or seen them, in nearly all seasons of the year.

(;-9)-(\$4:). Urillator areticus (Linn.). Black-throated LoON; BLACK-THRoated - Diver.

Exceedingly rare; Lake Michigan; winter; "oceasionally on Lake Michigan" (Gibbs' Birds of Mich.); "Upper Peninsula" (A. H. Boies); "Keweenaw Point" (Kneeland.

7-11-(\$4). Urinator lumme (Gunn.). Red-throated Loon; Red-throated Diver.

Rather common; "throughout the state. have taken several alive on snow in winter" (A. H Boies); winter; migrates north in spring; found on lakes and rivers in all parts of the state: "almost a yearly visitor in Kalamazoo Co." (Dr. M. Gibbs); "Keweenaw Point" (Kneeland); "found breeding at Green Bay. Wis." (Prof. Ludwig Kumlein); "breeds in Aretic regions" (Dr. A. K. Fisher).

\section{Family ALCID) E. The Auks.}

These curious water birds are speciaily marine and it is doubtful if they belong to our fauna; if ever seen here they are undoubtedly wanderers.

Genus Fratercula Briss.

8-1:3-(\$is). Fraterenla aretica (Linn.). Comon Puffin.

"Rare straggler" (Gibbs" Birds of Michigan); "have never heard of one on Lake Superior" (C. S. Osborn). I think this of doubtful occurrence in Michigan.

('ENUS SYNTHLIBORAMPHUS BRANITT.

9-21-(864). Syuthliboramphus antiquus (Gmel). Ancient Murrelet; Blackthioated Murrelet.

Prof. Ludwig Kumlein writes me that he has taken one specimen at Lake Koshkonong, Wis., and one on Lake Michigan. One was shot late in October by Rev, G. E. Gordon on Lake Koshkonong, Wis. (Geo. B. Sennett in The Auk for January, 1884) ${ }^{7}$ Coues says one straggler taken in Wisconsin.

GENUS CEPPHUS PALI.

10-27-(\$71). Cepphus grylle (Linn.). BLack Guillfirot.

"Not rare in Upper Peninsula, occasional seasons" (Dr. M. Gibbs); "may oceur as a rare straggler" (Prof. Ludwig Kumlein): "very rare even as an aceidental visitor" (C. S. Osborn).

Genus URiA Briss.

11-80-(87t). Uria troile (Linn.). Murre.

"Occasionally taken on Lake Superior" (Gibbs" Birds of Michigan). I think this a doubtful Michigan bird; "so do I-also all the other Alcidre" (Robt. Ridgway).

Genus AlCa Linn.

12-30-(\$77). Mea torda Linn. Razor-billed Auk.

"Irregular visitor to Northern Peninsula" (Gibbs' Birds of Michigan); "I have heard of one captured. but even this is not well authenticated" (C. S. Osborn); "the 
ehances are one hundret to one against the five preceding species appearing in Michigan even as wanderers. especially is this true of Fratercula arrtire" (Prof. J. A. Allen): "I concur with Prof. Allen" (A. H. Boies).

GENUS ALLE LINK.

13-34-(86:3). Ille alle (Linn.). SEA DOVE; DoveKIf, ALLE.

The late W. H. Collins reported killing one on Detroit River. Nov, 30, 1881, (O. and O. 4. Vol. VII, p. 111).

\section{Order LONGIPENNES. Long-Winged SWIMmers.}

FAMIY STERCORARIIDAE. SKUAS ANI JAFGFRS.

(iFINUS STERCORARIUS BRISS.

14-36-(765). Stercorarius pomariuus (Temm.). PonARINe JAEGer.

Very rare; one taken on Beaver Island, Michıgan, by Prof. Ludwig Kumlein. Reported (Butler's Birds of Ind.) from Lake Michigan; E. L. Mosley reports a specimen shot at Sandusky, O., Oct., 1889; the late W. H. Collins reported one specimen taken on Detroit River, and now in the collection of the Museum of Comparative Zoölogy, Cambridge Massachusetts.

\section{FaMLY LARIDA. GULLS AND 'Terns.}

More common near the Great Lakes; feed on fish and meat; the larger crulls often accompany vessels.

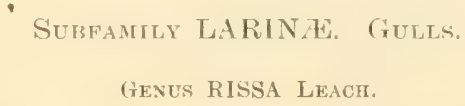

15-40-(75:). Rissa tridactyla (Linn.). Kixtiwake; Kiтtrwake GurL.

Rare accidental visitor" (Gibbs" Birds of Michigan); "arctic regions south in winter to New York" (Jorlan). I think this a doubtful Michigan species. Dr. Gibbs informs me that it is reported from Mackinac Island.

GENUS LARUS LINN.

16-42-(765). Larus glaucus Brunn. GLAucus Gult; ICE Guld.

Rare; "Upper Peninsula and one taken at Klinger's Lake, St. Joseph county, 1892" (A. H. Boies); "Lake Michigan" (Butler's Birds of Ind.); Prof. Ludwig Kumlein reports taking several specimens at Milwaukee, Wis.; "south in winter" to New York" (Jordan); embraced in the University list at Ann Arbor. and in the lists of Miles, Sager and Boies.

17-4:-(769). Larus leucopterus Faber. ICELAND GuLL; White-Winged Gull.

Rare; "Lake Michigan, winter" (Butler's Birds of Ind.); about all the great lakes; "rare on Lake Erie" (Jerome Trombley); "south to New York" (Jordan).

18-47-(771). Larus marinus Linn. GREAT BLACK-BACKed GulL.

"Kent county, March 28, 1889, and Mackinac Island" (S. E. White): "winter visitant on Lake Michigan Dr. Velie. Ridgway"s list of birds of I11.. 1874" (Gibl)s' Birds of Michigan). 
19-51a-(783). Larus argentatus smithsonianus Coues. Americix Herking Gule; Simithonian Gull.

Very abundant; throughout the state; migrant and winter resident; breeds; "nests abundantly on Isle Royal, Michigan" (Frank S. Daggett in O. and O., Vol. XV, p. 99); "common in January on Saginaw Bay" (N. A. Eddy in O. and O., Vol. IX, p. 5); "nests very extensively on hummocks on the ground at Gull Island, east of Escanaba," (L. W. Watkins); "breeds at Mackinac Island, and is common on the Grand river at Grand Rapids" (S. E. White); "common on Lake Erie" (Jerome Trombley); "Keweenaw Point" (Kneeland). This and Boneparte"s (xull are ofter sten as far inland as Lansing. They are common along all the great lakes. C. S. Osborn writes me that Gulls deposit barrels of eggs on the rocky island of Georgian Bay. These eggs are gathered by thousands and eaten by fishermen, or used in manufacturing eggine or egg albumen. The number is simply marvelous. See interesting article by Frank S. Daggett in O. and $\mathrm{O}$., Vol XV, 1890, p. 99. It is stated that some of the very numerous nests at Isle Royale were on the unstable icebergs.

20-54-(778). Larus delawarensis Ord. Ring-Billed Gull.

Common throughout the state; migrant and winter resident; A. H. Boies says this is a summer resident; "Kent Co. and Mackinac Island" (S. E. White); "frequently seen in spring" (Jerome Trombley); "breeds in Northern Peninsula" (Prof. Ludwig Kumlein); "all United States south to Mexico" (Jordan).

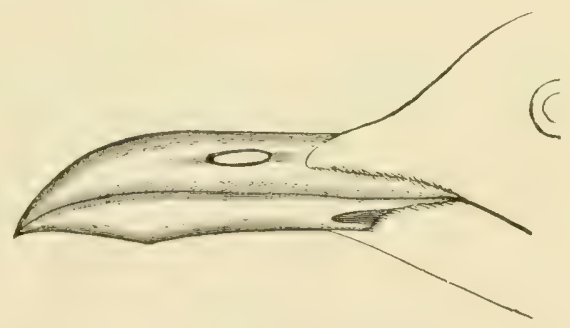

Laughing Gull.

21-i8-(786). Larus atricilla Linn. Laughing Gull; Black-headed GulL.

"Very abundant on the Great Lakes, probably breeds in the Northern Peninsula" . (Gibbs' Birds of Michigan); very rare; "north if it occur at all" (Dr. A. K. Fisher); "fairly common" (Prof. Ludwig Kumlein); "common migrant on Lake Erie" (Jerome Trombley); "one killed in Washtenaw Co. in 1884" (L. W. Watkins). This species is given in Dr. Sager's list of 1839.

29-59-(787). Larus franklinii Sw. and Rich. Franklin's Guld.

"Not rare on Lake Michigan during winter and spring" (Gibbs' Birds of Michigan); "occasional migrant and rare winter visitor in Indiana" (Butler"s Birds of Ind.); "chiefly west of the Mississippi" (Jordan).

2:3-60-(758). Larus philadelphia (Ord.). Bonapatete's (4ull; Bonaparte's Rosy GulL.

Rather common in spring and fall; "throughout the state" (A. H. Boies); of ten seen inland; frequently killed at Lansing; "common at Bay City in Jan." (N. A. Eddy in O. and O., Vol. IX, p. 5); taken in Oakland Co., by J. B. Purdy; "about our inland lakes" (W. C. Brownell); "rather rare in Kalamazoo county" (Dr. M. Gibbs); found breeciing on St. Clair Flats by W. H. Collins (Bull. Nutt. O. Club, Vol, V, p. 61); "occa- 
sional in spring in Monroe Co." (Jerome Trombley): "Keweenaw Puint" (Kneeland); "breed near Escanaba" (Prof. Ludwig Kumlein).

GENUS XEMA LEAch.

24-62-(790). Xema sabinii (Sab.). Sabine’s Gull; Forked-tailed Gull.

"Lake Michigan" (Butler's Birds of Ind.); " south to New York" (Jordan).

\section{Subfamly STERninfe. Terns: Sea Swallows.}

(ienus GELOCHELIDON Brehm.

25-63 (792). Gelochelidon nilotica (Hasselq.). Guld-millei) Tern; Marsh Tern.

Rather common; " a straggler and rather rare in Kalamazoo county" (Dr M.Gibbs); Great Lakes; often abundant on Lake Michigan; "often common on Lake Erie " (Jerome Trombley); "Ohio, Illinois and Michigan" (Butier's Birds of Indiana p. 108); "breeds on St. Clair Flats" (A. B. Covert): N. A. Eddy has found it common on Saginaw river in January.

\section{Genus STERNA LINN.}

\section{6-6t-(793). Sterna tschegrava Lepech. Caspian 'Tern.}

Very rare; probably a straggler; one taken by the late W. H. Collins of Detroit is now in the National Museum: Great Lakes; winter: "faken repeatedly at Mackinac Island, identification certain " (S. E. White): said to breed on islands of Lake Michigan (see Davie's Nests and Eggrs of North American Birds. p. 333). Prof. Ludwig Kumlein has taken several sets of eggs at Green Bay, Wisconsin.

27-65-(794). Sterna maxima Bodt. Royal Tern; Cayenne 'T'ern.

Rare; spring and summer; Lake Michigan; "rare summer visitant, occasionally taken on Lake Michigan in late spring" (Gibbs" Birds of Michigan): common at Mackinac Island" (S. E. White); "Upper Peninsula" (A. H. Boies); see Butler's Birds cf Indiana, p. 108.

28-69-(798). Sterna forsteri $N$ utt. Foster's T'Ters.

Not common; spring, summer and autumn; "Hillsdale county" (A. H. Boies); "breeds on St. Clair Flats" (A. B. Covert); "breeds freely in Upper Peninsula" (Prof. Ludwig Kumlein); "breeds on shore of Lake Superior" (H. Nehrling).

29-70-(797). Sterna hirundo Linn. Common Tern; Wilson's Tern; Sea Swallow. Common; migrant; "Saginaw Bay" (N. A. Eddy): "common on Lake Erie" (Jerome Trombley); "breeds on St. Clair Flats" (A. B. Covert); "throughout the summer in northern Indiana, where it may breed" (Butler"s Birds of Indianit); "Keweenaw Point" (Kneeland): "breeds in Upper Peninsula" (Porf. Ludwig Kumlein): nests on ground: eggs four, very variable, often pinkish drab, spotted with brown or gray; nests rude. This bird is embraced in Dr. A. Sager's list of 1839.

30-71-799). Sterna paradisaa Brunn. Arctic Tern.

"Not a common migrant" (Gibbs' Birds of Michigan); "south to New York" (Jordan): "sometimes breeds at Lake Koshkonong. Wis." (Prof. Ludwig Kumlein I. 


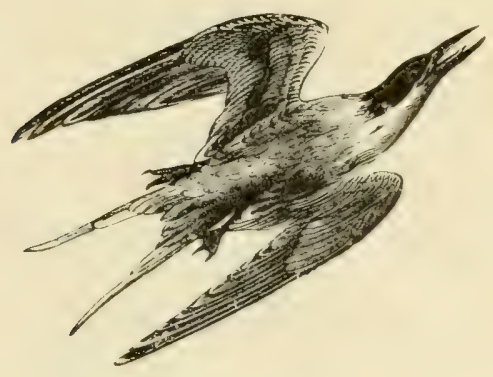

Roseate Tern.

31-72-(800). Sterna dougalli Montag. Roseate Tern.

Rare; probably a straggler; Lake Michigan; "oceasional visitor" (Gibbs' Birds of Michigan); one specimen recorded in catalogue of the Birds of Michigan in the museum of Kent Scientific Institute at Grand Rapids, by E. I. Moseley; " Prof. Smith shot two from a flock of five, in Hillsdale, in the spring of 1892" (F. M. Falkner); "common on Lake Erie and Raisin River" (Jerome Trombley); "probable summer resident" (Dr. J. B. Steere).

\section{:32-74-(801). Sterma antillarum (Less.). Least Tern.}

Given in Gibbs' Birds of Michigan; "reported as a summer resident in northern Indiana" (Butler's Birds of Ind.); "certainly breeds at St. Clair Flats" (Dr. W. C. Brownell).

\section{3-75-(804). Sterua fuliginosa Gmel. Sooty T'ers.}

Dr. G. W. Topping, of DeWitt, is authority for one having been taken near DeWitt, in the spring of 1880 . Coues says "along the Atlantic coast;" Ridgway says "north to Carolinas. casually to New England:" if taken in Michigan its occurence was doubtless a rare accident.

\section{GeNus HYDROCHELIDON BOIE.}

:4-77 1306). Hydrochelidon nigra surinamensis (Gmel.). Bhack Tern: Short. talled Tern.

Abundant; spring and summer; "Hillsdale Co." (A. H. Boies); "Mackinac Island" (S. E. White); taken at St. Clair Flats by W. H. Collins, (Bull. Nutt. O. Club, Vol. V, p. 61); "common on Lake Errie and Raisin River" (Jerome Trombley); "nests on floating debris at St. Clair Flate" (W. A. Davidson); " common at Saginaw " (Miles' Birds of Michigan); "Kent Co." (S. E. White); breeds; "abundant breeder in Wayne Co." (B. W. Swales); "probably raises two broods" (Amos W. Butler); nests about lakes in June on hummocks on the ground, often built up several inches; eggs three, greenish, "and spotted" (Gibbs).

\section{Order S'Tleganopodes. 'lotipalamate Sivmmers.}

\section{Family PHALACROCORACIDA. Cormorants.}

Heavy hooked-billed birds; food, fish; they do not plunge, but dive for their food. 
GeNUS PHALACROCORAX BRIss.

35-119-(750). Plualacrocorax carbo (Linn.). Cormorast. Michigan.

"An occasional visitor" (Gibbs' Birds of Michigan); of doubtful occurrence in

36-120-(751). Phalacrocorax dilophus (Sw. and Rich.). Double-Crested Cormorant.

"Common at times" (Dr. M. Gibbs); migrant or winter resident; "Southern Michigan, Hillsdale Co." (A. H. Boies); "our commonest species" (Jordan); "breeds in great numbers in Wis." (Davie's Nests and Eggs of North American Birds). Dr. Ezra S. Holmes, of Grand Rapids, has a fine male which he took in northern Indiana, just over the Michigan line, and Mr. Levi Broas took a fine female near Ionia, which is now in our museum.

\section{Family PELECANIDE. Pelicans.}

Heavy birds with long, hooked beaks; large pouch beneath the lower jaw; food. fish; either plunge for or scoop up their food.

GFNUS PELECANUS LIN.

\section{7-125-(748). Pelechuns erythrorhynehos Gmel. American White Pelicañ.}

Very rare; "Hillsdale and Lenawee counties." (A. H. Boies); "one killed on Saginaw Bay, one in St. Joseph Co, and it has been seen in the Upper Peninsula" (Dr. M. Gibbs); one killed in Allegan county (O. and O., Vol. XVII. 1892, p. 143); one in museum from Berrien Co.: "one taken at Tecumseh. Lenawee Co.. in 188:" (L. W. Watkins): "two killed in a flock of forty or fifty, at Cambria, Mich., and now mounted in a store in Hillsdale" (F. M. Falconer): "Keweenaw Point" (Kneeland).

\section{Order ANSERES. Lanelitrostrat SWImars.}

Family ANATIDE. DuCks, Geese ayd Swans.

Birds with thick feathers. lamellate bills, palmate feet; food. mostly vegetable, some insects, etc.

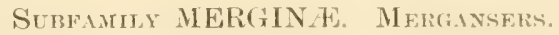

GenUs MERGANSER. Briss.

38-129-(743). Merganser americanus (Cass.). Amerrcax Mfredxser; Merg.sSER; GoOSANDER; Fish DUCK.

Common; "throughout the state" (A. H. Boies); migrant or winter resident: reported from St. Clair Flats; "have seen acres of water covered by them in spring" (Dr. W. C. Brownell); "Kent Co. and Mackinac Island" (S. E. While); " common at Iron 
Mountain " (E. E. Brewster); "Keweenaw Point" (Kneeland): " common migrant on Lake Erie" (Jerome Trombley): included in Dr. Sager's list of 1839; occasionally a summer resident, especially in the northern part of this state. where it may breed. This tine bird is very common at Saginaw Bay and about all the lakes in spring and fall; it is not fit for table use.

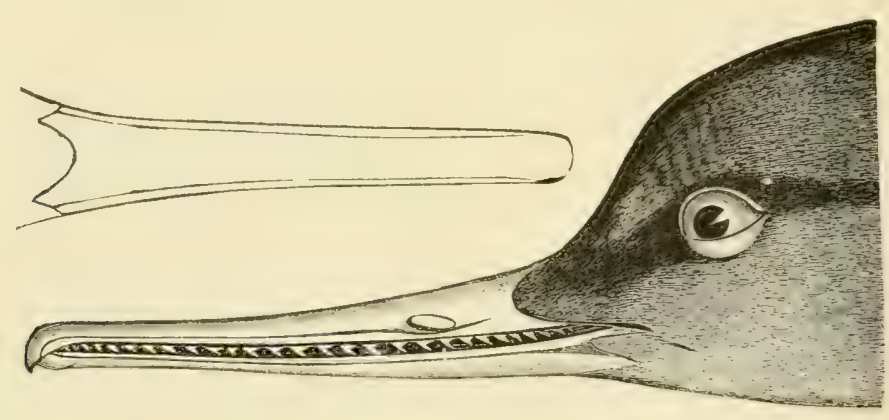

Red-breasted Merganser, natural size.

39-130-(744). Merganser serrator (Linn.). Red-breasted Merganser.

Rare; migrant; winter resident; often in large flocks; we have it from Saginaw Bay: taken at Plymouth by J. B. Purdy: A. H. Boies reports it from St. Joseph Co.; "common migrant on Lake Erie" (Jerome Trombley); "Keweenaw Point" (Kneeland); "breeds in Northern Peninsula" (Prof. Ludwig Kumlein); Mr. S. E. White took nine eggs from a nest on Round Island, near Mackinac Island. the nest was near the water's edge under a low cedar. Dr. A. K. Fisher thinks it doubtful if it breeds in Michigan. This Merganser is given in Sager's list of 1839.

Genus LOphODYTES Reich

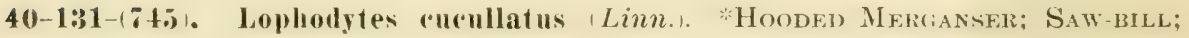
Tор-кNOT.

Very abundant; "throughout the State" (A. H. Boies); migrant; "Kent Co. and Mackinac Island" (S. E. White); "common at Iron Mountain" (E. E. Brewster); "Keweenaw Point" (Kneeland): " common migrant on Lake Erie" (Jerome Trombley); taken at Plymouth by J. B. Purdy; taken frequently at Pine Lake; in April and Sept; may breed as it is occasionally taken in summer: "doubtless breeds. eggs usually ten to twelve, may range from six to eighteen " (Amos W. Butler): said to nest in bollow trees; "feeds on snails and crabs, exeellent table du(ck" (J.H. Whitehead); "flesh almost as rank as that of the two preceding." (Ludwig Kumlein): this is one of our handsomest ducks. In California this duck is not noticed by hunters, as it has no value in the market.

Genus ANAS Linn.

41-132-(707). Anas boschas Linn. *Maldard; Mallard Duck; Green Head.

Very abundant; throughout the entire State: summer months, though usually a migrant; March, April, Sept. and Oct.; reported common in Kalamazoo and Wayne 
counties; "abundant in Monroe Co." (Jerome Trombley); "abundant throughout the State" (A. H. Boies); "nests by thousands at St. Clair Flats" (Dr. W. C. Brownell); "very common in Kent Co. and Mackinac Island" (S. E. White); "Keweenaw Point" (Kneeland); breeds; nests on the ground; Dr. Gibbs reports a nest in a hollow tree; nest elaborate; eggs six to twelve, color dirty white to olive green; excellent game bird. Our domestic ducks come largely from this species.

\section{2-133-(708). Anas obsenra Gmel. Buack Duck; Dusky Duck.}

Common in fall and spring; occasional in fall and summer; "migrant and occasional winter resident in Northern Indiana" (Butler"s Birds of Indiana); "throughout the entire State" (A. H. Boies); "Keweenaw Point" (Kneeland); reported from Bois Blanc Island; "Monroe Co." (Jerome Trombley); "undoubtedly breeds" (Dr. M. Gibbs); "Mr. W. A. Davidson took a nest at St. Clair Flats" (Dr. W. C. Brownell); Dr. J. B. Steere gives it as a questionable summer resident; Prof. Ludwig Kumlein writes me that this duck breeds in Northern Wisconsin and without doubt in our Northern Peninsula.

\section{3-135-(711). Anas strepera Linn. *GaDwaLL.}

"Common throughout the entire state" (A. H. Boies); April and October; migrant; "breeds in the Northern Peninsula" (Prof. Ludwig Kumlein); "Keweenaw Point" (Kneeland); often taken at Park and Pine Lakes near Lansing; Dr. J. B. Steer" gives it as a summer resident with a question mark; included in Sager's list of 1839.

\section{4-137-(713). Anas americana Gmel. Baldpate; American Widgeon.}

Common; migrant; April, May and October; "common in Monroe Co., but not known to breed" (Jerome Trombley); reported common at St. Clair Flats; "common in Kent Co." (S. E. White); Dr. J. B. Steere gives it as a doubtful summer resident; "rare summer resident in Northern Indiana, where it breeds" (Butler's Birds of Ind.); "Keweenaw Point" (Kneeland); we have fine specimens in our museum taken at Pine Lake. This species is included in Dr. A. Sager's list of 1839.

\section{5-139-(715). Anas earolinensis Gmel. Green-winged T'eal.}

Common; "throughout the state" (A.H. Boies); migrant; May and October; taken at Pine Lake near the college; this and the four succeeding species all taken at Plymouth by J. B. Purdy; "Keweenaw Point" (Kneeland); "migrant in Monroe Co." (Jerome Trombley); "breeds at St. Clair Flats" (Dr. W. C. Brownell); one of our best table ducks.

\section{6-140-(716). Anas discors Linn. *BLuE-Winged 'T'Eal.}

Very common; "throughout the state" (A. H. Boies); April and October; usually a migrant; "summer resident" (Dr. J. B. Steere); "common at Au Sable" (N A. Eddy); two nests found and eggs taken by S. E. White in Allegan Co., May 28, 1891; "found breeding at the mouth of Kalamazoo river" (Dr. M. Gibbs); "oceasionally" breeds in Monroe Co." (Jerome Trombley); "surely breeds at St. Clair Flats" (Dr. W. C. Brownell); "breeds at Sault Ste. Marie" (C. S. Osborn); "Keweenaw Point " (Kneeland); nests on ground, in swamp grass: eggs twelve. Mr. J. B. Purdy writes me that he has frequently taken the young. some of which were yet unable to fly, at Plymouth. 
Genus SPATUlat Boie.

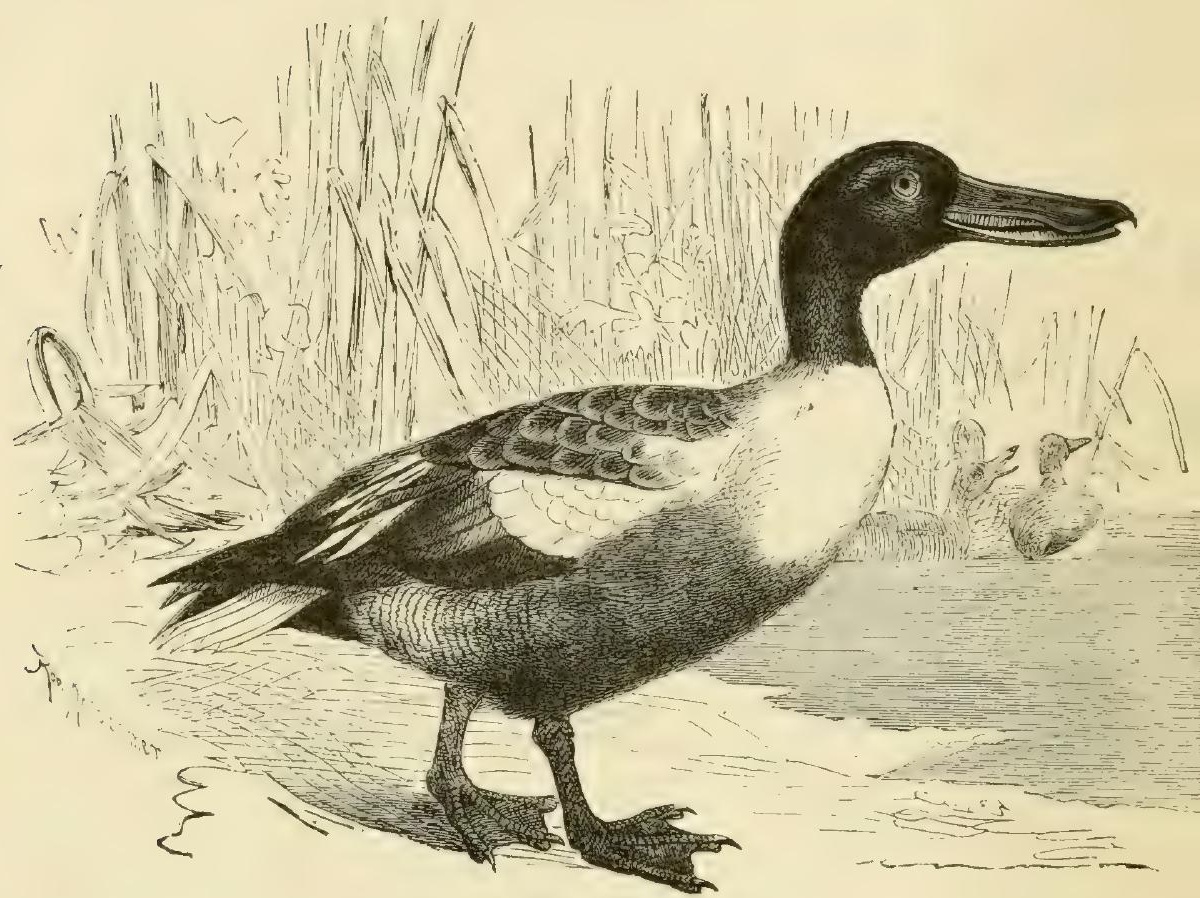

Shoveller, one-fourth natural size.

47-142-(718). Spatula clypeata (Linn.). Shoveller; Spoonbill.

Very common; migrant; "breeds in the Northern Peninsula" (Prof. L. Kumlein); bill very broad; lamellæ of bill very marked; taken frequently at Pine Lake, near here, in April and May; Dr. Steere gives it as a questionable summer resident; "probably breeds in Northern Indiana" (Amos W. Butler); "St. Joseph and Monroe counties" (A. H. Boies); "common on Lake Erie" (Jerome Trombley); "Keweenaw Point" (Kneeland); in Sager's list of 1839.

Genus DAFILA Steph.

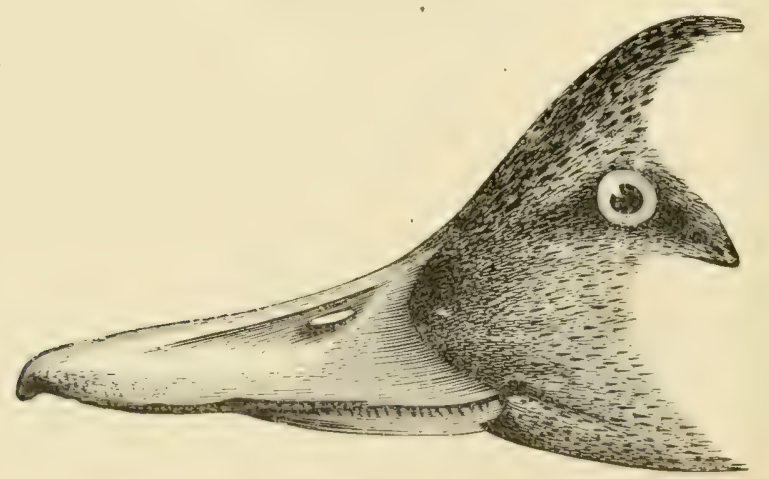

Pintail, female, natural size. 
45-14:-(710). Dafila acuta (Linn.). Pintail; Sprigtail.

Rather common; "throughout the State" (A. H. Boies); "Keweenaw Point" (Kneeland); migrant and possibly winter resident; Sept. and May; "Monroe Co." (Jerome Trombley); "never saw it in January" (Dr. M. Gibbs); "reported common at St. Clair Flats; "migrant" (Dr. J. B. Steere); "doubtful winter resident" (Amos W. Butler); embraced in Sager's list of 1839.

GENUS AIX BOIE.

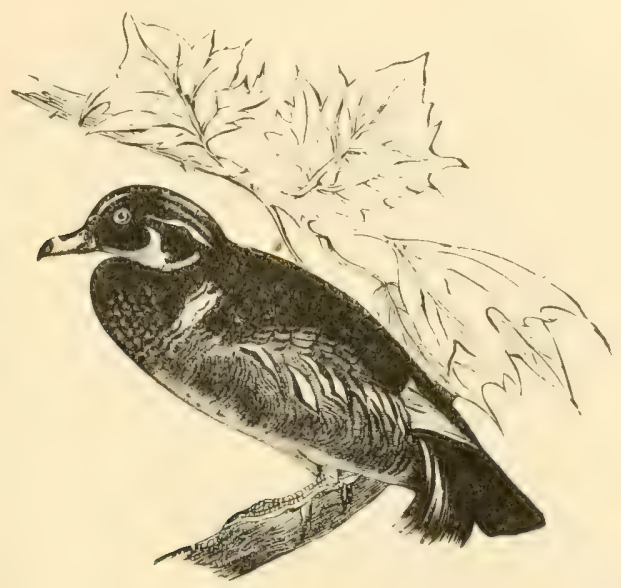

Wood Duck, reduced.

4!)-14-(719). Aix sponsa (Limn.). *Wood Duck; Sumare Duck: Tree Duck.

Very common; "throughout the entire State" (A. H. Boies); I have it authentically reported from Kent, Monroe, Washtenaw. St. Clair and Muskegon counties and Mackinac Island; "common at Iron Mountain" (E. E. Brewster); "Keweenaw Point" (Kneeland); summer resident; March, rarely Feb., to Nov.; "once common but now rare in Monroe Co." (Jerome Trombley); breeds abundantly; nests in the tops or hollows of trees. hence called tree duck; eggs, dirty yellowish white; one of our handsomest ducks: an excellent game bird: " the males sometimes feed in flocks during the breeding se'ason " (S. E. White). This beautiful hird is common on the Red Cedar, which passes by our college campus, where I have often taken it from April to Oet. Unfortunately these birds, formerly so common, are heing rapidly thinned by hunters.

(iEnUs AYTHYA Bote.

j0-146-(723). Aytlya americana (Eyt.). Redhead; Anerican Pochard.

Quite common; "throughout the entire state," (A.H. Boies); spring and fall: migrant; "common on Lake Erie" (Jerome Trombley); "abundant at Au Sable" ( A. Eddy); "Keweenaw Point" (Kneeland); I also have reports from Kent and St. ("lair "ounties; taken at Plymouth by J. B. Purdy: this is frequently taken at Pine Lake near here in October; found breeding at St. Clair Flats by W. H. Collins (Bull. Nutt. O. Club, Vol. V, p. 61). Davie, p. 58, mentions it as breeding in Michigan; included in Sager's list of $18: 39$. 


\section{1-147-(724). Aythya vallisneria (Wils.). CANvas-Back.}

Not very common; taken on Detroit river by J. B. Purdy migrant; more abundant near the Great Lakes; "common on Lake Erie" (Jerome Trombley): "common at St. Clair Flats" (Dr. W. C. Brownell); "not found on inland lakes, but rarely taken at St. (Yair Flats and Saginaw Bay" (A. H. Whitehead): "Keweenaw Point" (Kneeland); "common where wild celery abounds, rare at Sault Ste. Marie" (C. S. Osborn); perhaps our finest game duck.

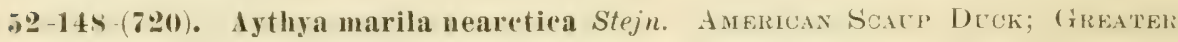
Scaup Duck; Greater Blue-bill; Greater Blackhead.

Common; "migrant at Ann Arbor" (Dr. J. B. Steere); fall and spring, often very common in fall; migrant; one nest reported by W. H. Collins from St. Clair Flats. (Bull. Nutt. O, Club, Vol. V, p. 61); "common at Lake Erie" (Jerome Trombley); "Keweenaw Point" (Kneeland); taken at Plymouth by J. B. Purdy; we find it very common at Pine Lake in Oetober; "common game duck" (Dr. W. C. Brow nell).

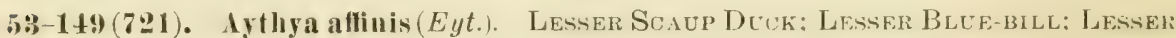
BLACKHEAD.

Very abundant; migrant; taken plentifully at Pine Lake, five miles east of the college, in October and November; " common in Detroit markets" (Dr. W. C. Brownell); "exceedingly common at Au Sable, November, 1884" (N. A. Eddy); "common at Iron Mountain" (E. E. Brewster); "migrant at Ann Arbor" (Dr. J. B. Steere); "common at Lake Erie" (Jerome Trombley); one nest reported by W. H. Collins at St. Clair Flats. (Bull. Nutt. O. Club, Vol. V, p. 61); it very likely breeds here sparingly, north abundantly; "This is a good game bird and decoys very easily" (S. E. White).

\section{4-150-(722). Aythya collaris (Donov.). Ring-Necked Duck; Blackhead.}

Rather common; "throughout the state during migration." (A. H. Boies); taken at Plymouth by J. B. Purdy; "Iron Mountain, April 18, 1889" (E. E. Brewster); migrant: March and September; Davie, p. 70, says it breeds from New York to Wisconsin, and north; not rare at Pine Lake in Ostober and November; given in Dr. A. Sager's list of 1839; "tolerably common in Northern Indiana" (Butler's Birds of Ind.).

(Hendo GlaUCIONETTA Stejn.

\section{151-(725). Glancionetta clangula americana (Bonap.). American Golden-eye;} Golden-eye; Whistler; Gak̀rot.

"Common from the north, late in November, and often remains all winter on open spots of swift running rivers, dives at the flash of a gun, and will escape shot at thirty feet to my certain knowledge" (Dr. M. Gibbs); "throughout the state" (A. H. Boies); reported from Kent Co.; migrant; "Dr. Brayton gives this as a winter resident on Lake Mich." (Amos W. Butler); "winter resident on Lake Michigan and open inland lakes" (Prof. Ludwig Kumlein); "Keweenaw Point" (Kneeland); "commron on the rapids of the St. Mary"s River all winter" (C. S. Osborn); "this bird is taken at Pine Lake, is a fine game duck and is so quick to dive that it is difficuit to shoot it on the water" (A. H. Whitehead). There are several of these ducks in the collection of Mr. Levi Broas, of Belding, Mich., taken by him in that locality. I think this a common species all through the Southern Peninsula. 
5(i-152-(726). Glancionetta islandica (Gmel.). BARrow's GoldEN-EYE.

Brayton in his "Birds of Indiana" gives this as a winter resident of Lake Michigan; "une taken at Hillsdale from a fluck on the lake in 185?" (F. M. Falconer): "only taken on Lake Michigan as a rare straggler" (Ludwig Kumlein); "not uncommon winter resiclent on Lake Michigan" (H. Nehring); embraced hy Storkwell in his list of Michigan birds (F. and S., Vol. VIII. pp. 23, 380.

Genos CHARITONETTA STEJN.

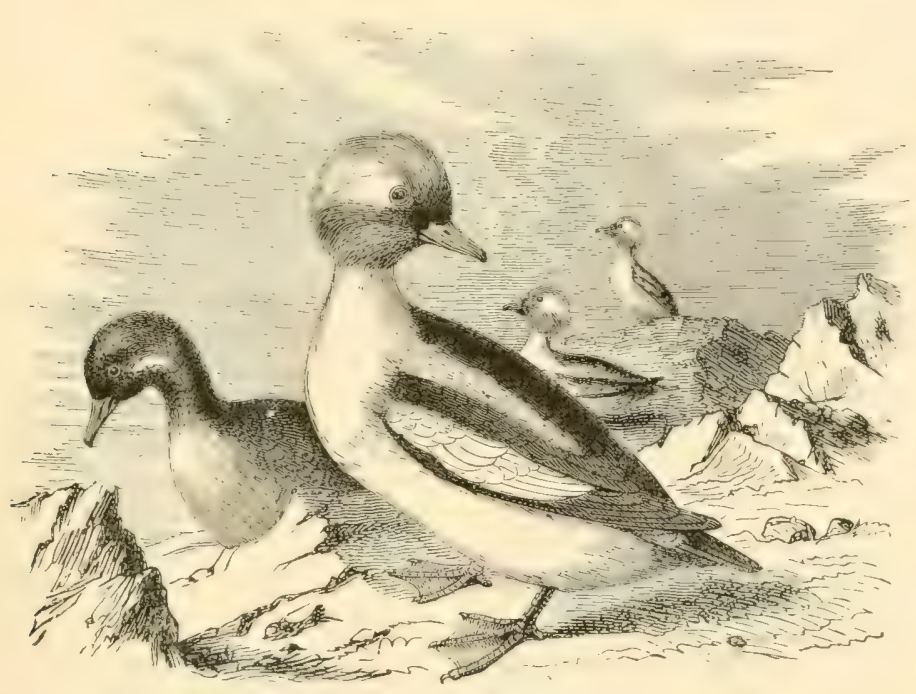

Buffle-head, much reduced.

57-15:-(797). Cliaritonetta albeola (Linn.). *Buffle-hman; Buttek-BıLt; Sprat DUCK.

Very abundant; small flocks; "throughout the state" (A. H. Boies); spring and fall: winter resident; occasional in summer; "probably breeds at St. Clair Flats" (Dr. W. C. Brownell); reported from Kent and St. Clair counties; "common on Lake Erie" (.Jerome Trombley); "Au Sable in October, 1884" (N. A. Eddy); "common at Au Sable" (N. A. Eddy); "not rare at Traverse City" (Dr. M. L. Leach); "common at Irop Mountain" (E. E. Brewster); "Keweenaw Point" (Kneeland); taken by Dr. Atkins in April and July; we have taken several at Pine Lake in November. This duck is rapid of flight and quick to dive.

\section{Genus Clangula Leach.}

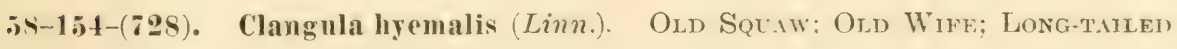
DUCK.

Winter resident; more abundant near Great Lakes; one specimen taken near here at Pine Lake; reported from Kent Co.; occasionally common in Kalamazoo Co.- "A Hock noted Feb. 1884" (Dr. M. (ribbs); "two specimens taken in Grand Traverse Co." (Dr. M. L. Leach); "St. Joseph Co." (A. H. Boies); common migrant on Lake Erie" (Jerome Trombley); " abundant on Lake Michigan" (Butler's Birds of Indiana). 
GENUS HISTRIONICUS LESS.

59) 155-(7:30). Histrionicus histrionieus (Linn.). HARLequin DuCh.

Very rare; admitted in Gibbs' Birds of Michigan. A. H. Boies thinks this should be included. Prof. Ludwig Kumlein writes me that he has taken two specimens in Jefferson Co., Wisconsin.

\section{Genus SOMATERIa Leach.}

(60)-160-(734). Somateria dresseri Sharpe. Amemican Ender.

"Occasionally seen on Lake Superior" (Gibbs" Birds of Michigan); the late W. H. Collins reported taking a young male in Detroit on Detroit river, Dec. 1882. If this bird occur in Michigan it must be as an accidental straggler.

(i1-162-(736). Somateria spectabilis (Linn.). KING EIDER.

"Straggler taken at Milwaukee and Grand Haven, Michigan" (Prof. Ludwig Kumlein). Dr. A. K. Fisher thinks this very doubtful.

Genus OIDEMIA Flei.

62-16:-737). Oidemia americana Sw. and Rich. American Scoter; Amertcan BLACK SCOTER.

"Rare accidental visitor" (Gibbs' Birds of Michigan); taken at Au Sable, Oct., 1884 (N. A. Eddy in O. and O., Vol. IX, p. 41); "not uneommon in winter on Lake Michigan" (H. Nehrling and L. Kumlein).

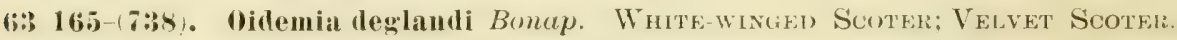
Rather rare; migrant; two in our museum taken at Pine Lake near here in 1885; "Lake Michigan" (Butler's Birds of Ind.); "this bird is becoming more numerous, now frecuently taken during migration at Park and Pine Lakes near Lansing" (C'. J. Davis: "occurs regularly on Lake Michigan" (Prof. Ludwig Kumlein); "cannot be called common in Upper Peninsula" (C. S. Osborn).

(it 16(; 139)1. Oidemia perspicillata (Linn.) SLrF Deck: Surf Scoter: Sea Coot

Very rare; winter visitor; "Au Sable and Saginaw Bay" (N. A. Eddy in O. and O., Vol. IX, 1884, pp. 4 and 41); "regular migrant on inland lakes of Wisconsin" (Prof. Ludwig Kumlein); "not uncommon on Lake Michigan" (H. Nehrling); "taken near" Iron Mountain Oct. 20, 1890" (E. E. Brewster).

GENUS ERISMATURA BONAP

6.) 167-(7+1). Erismatura rubida (Wils.). RUDDy DUCK; BLACK JACK.

Exceedingly abundant; "throughout the State" (A. H. Boies); migrant; April, Oct. and Nov.; very common at Pine Lake; taken in Oakland county by J. B. Purdy: reported from Kent Co.; "exceedingly abundant some falls in Kalamazoo Co." (Dr. M. (Gibbs); "common migrant on Lake Erie" (Jerome Trombley); Mr. Jerome Trombley reports large numbers on Raisin River in spring of 1888; "at Mackinac Island" (S. E. White); given by Dr. J. B. Steere as a summer resident; flocks; very fearless and stupid; "breeds in Northern Peninsula": (Prof. Ludwig Kumlein); the late W. H. Col lins reported taking eggs; " not very good eating" (A. H. Whitehead).

(iENus CHEN BoIF.

(66-16!-(696). Chen hyperborea (Pall.). Lesser SNow Goose.

Rare; nigrant; reported from Michigan in the catalogue of the museum of the 
Kent Scientific Institute, by E. L. Moseley; included in Butler's Birds of Indiana: "accidental if in Michigan " (Prof. Ludwig Kumlein): "northern counties of Indiana" (Butler's Birds of Indiana). It is possible that the next is often mistaken for this one.

67-169a-695). Chen hyperborea nivalis (Forst.). Greater Snow Goose.

Common; Mar. and Oct. and Nov.; throughout the State; migrant; Mr. A. H. Boies has seen large flocks flying in Hillsdale and Lenawee counties during winter; Dr. M. Gibbs reports taking three of these from a flock of ten or more Oct. 24, 1884; "Keweenaw Point" (Kneeland); doubtfilly given as a Michigan migrant by Dr. J. B. Steere; known to alight not infrequently near Lansing; excellent table bird.

65-169.1-(694). Chen chrulescens (Linn.). BLue Goose.

One specimen reported in Kent Scientific Institute at Grand Rapids by E. L. Moseley; two captured from a flock on St. Clair Flats by the late W. H. Collins; "regular migrant throughout Wisconsin" (Prof. Ludwig Kumlein); "Indiana" (Butler"s Birds of Indiana).

GeNUS ANSER Briss.

(69-171a-(693). Anser albifrous gambeli (Hartl.). * ANIERICAN White-Fronted Goose.

"Transient, rare" (Dr. M. Gibbs);" migrant" (Dr. J. B. Steere); " Keweenaw Point" iKneeland); "Indiana, rare migrant" (Butler"s Birds of Indiana). This is unquestion ably very rare in Michigan.

GENUS BRAN IA ScOP.

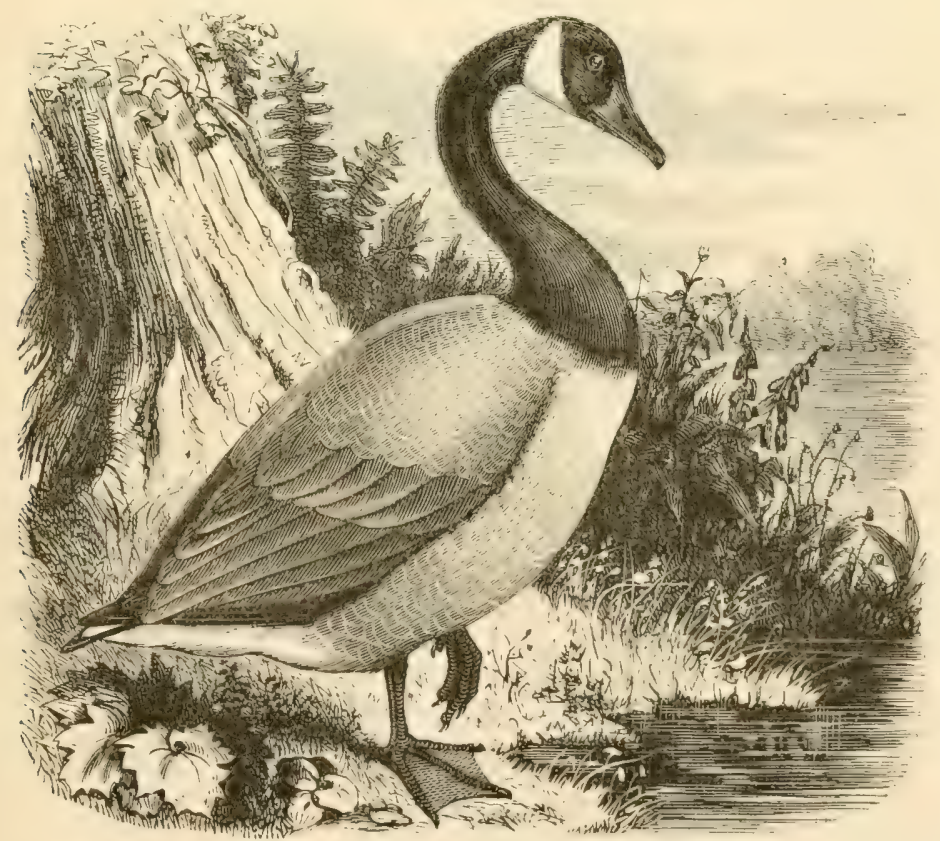

Canada Goose, reduced. 
71)-172-702). Branta cauadensis (Limn.). * Canada Goosf; Comnon Wild Goose.

Common; Feb. to Apr., and Sept. even to Dec.; throughout the entire State; often seen Hying over in March and November, and occasionally much earlier and later in large flocks. which are usually arranged in quite definite V shaped figures; more commonly seen early or late in the day, and heard at all times of night; frequently alights; "often in wheat fields" (Jerome Trombley); "Keweenaw Point" (Kneeland); nests on the ground; eggs, five to six, yellowish green, "not distinguishable from those of our common geese" (Dr. C. W. Brownell). These birds are very shy and so are rarely taken. *.Mr. Briggs of Wayne Co. has a fine pair. They attempt to migrate each season, which he prevents. They breed well in continement. They cross readily with common geese, but the hybrids are infertile" (Dr. W. C. Brownell); "will sometimes swim up to ducking stools, and fly low in foggy weather" (L. S. Foster).

71-172a-(704). Branta canadensis hutehinsii (Sw. and Rich.). Hutchins' Goose.

Rare migrant; reported in catalogue of birds of Michigan in the Kent Scientific Institute by E. L. Moseley; taken by the late W. H. Collins on St. Clair Flats. Amos W. Butler gives it as a rare migrant in Indiana; and, upon Dr. Brayton's authority, says it formerly bred in that state (Birds of Indiana, p. 25).

7:2-17:2b-(70:2a). Branta canadensis occidentalis (Baird). White-chezked Goosf. Reported by the late W. H. Collins, who was a very accurate observer. Dr. A. K. Fisher thinks this doubtful.

72-17:2e-(703). Branta canadensis minima Ridgw. Cackling Goose. Reported by the late W. H. Collins.

\section{4-173-(700). Branta bernicla (Linn.). Brant.}

Rare or accidental; "common wild goose in the Upper Peninsula" (A. H. Boies); reported from Michigan by Robert B. Lawrence (Forest and Stream, Vol. XXXII, p. 316); migrant; this species while more common near the ocean, is said to occur not rarely in Michigan and the surrounding states; "I have often seen them" (Dr. W. C. Brownell); "Indiana" (Butler's Birds of Indiana); good game bird.

Gents OLOR Wagler.

7.5-180-(689). Olor colnmbianus (Ord). *Whistling Swan; American Swan.

Rare; migrant; occasional in summer; one in museum taken at Maple Rapids; one taken at Plymouth by J. B. Purdy; one killed at Mason, this county, Nov. 28, 1878; "have known several to be shot about our inland lakes" (Dr. W. C. Brownell); one taken by Mr. Levi Broas near Ionia and now in his fine collection; two taken by E. A. Lockwood in the month of December at South Haven (Am. Field, Vol. XXVII); "they occasionally occur in flocks in Jackson and Washtenaw counties, where they have been taken repeatedly. They are very shy and remain near large inland lakes" (L. W. Watkins); "not infrequently seen in Lenawee and Hillsdale counties" (A. H. Boies); "oceasionally shot by hunters on Lake Erie" (Jerome Trombley); "Keweenaw Point" (Kineeland); embraced in Dr. A. Sager's list of 1839.

76-181-688. Olor buccinator (Rich.). Trumpeter Swan.

Rare; migrant; "Hillsdale Co." (A. H. Boies); one taken in Kent Co. by E. S. Holmes and now in his collection at Grand Rapids; included in the lists of Michigan birds by Covert, Fox, Stockwell and Steere; counties of Northern Indiana (Butler's Birds of Indiana). 
Order HeROdTONES. Herons; Storks; Ibises; mtc.

\section{Suborder IBIDES. Spoon-billis ANd Ibises.}

FAMILY IBIDID E. IBISES.

Long bills; rather short legged waders; food, fish and other aquatic animals.

GENUS PLEGADIS KAUP.

77-186-(649). Plegadis autumnalis (Hasselq.). GLossy IBIs.

Very rare; occasional straggler; one Michigan specimen reported in the catalogue of the Kent Scientific Institute by E. I. Moseley; "killed Oct. 6, 1884, on Saginaw Bay" (N. A. Eddy O. and O., Vol. X, p. 9).

\section{Suborder Herodil. Herons; Egrets; Bitterns: etc.}

Family ARDEID E. Herons; Bitterns; etc.

Feed on fish, frogs and toads, etc.; about marshes; not usually game birds.

Subamli BOTAURINÆ. Bitterns.

genus botaURUS herrman.

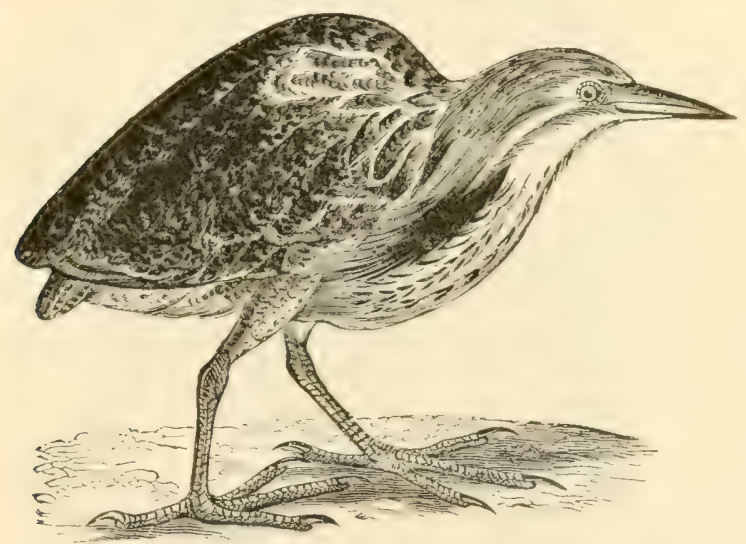

Bittern, reduced.

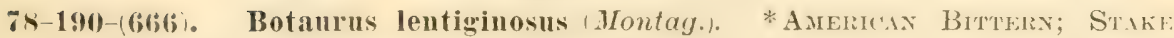
Driver; Shytepoke; Indin Hen; "Thunder Pumper; "Barrel Maker;" Plum Pudpen.

Common; throughout the state; April to August; "common in Monroe Co." (Jerome Trombley): "Mackinac Island" (S. E. White); "common at Sault Ste. Marie " (A. H. Boies): "Keweenaw Point" (Kneeland); reported from Kent Co. and Ann Arbor: breeds; nests, but not in colonies, on the ground, usually in marshes and often surrounded by water; "breeds in great numbers about marshes in Shiawassee county" (Dr. W. C. Brownell), occasionally in meadows; nest elaborate; eggs three to seven, drab or mud color; the males make as a love note a sound like "plum pudden," also another like a ringing or pumping sound, as if pounding a barrel (see article by Bradford Torrey in "The Auk" for January 1889); a very common bird in nearly all parts of Michigan; destroys field mice. For interesting articles on this bird by Dr. 
M. Gibbs. describing notes and contortions in uttering them, see O. and O., Vol, XIV. 1889. p. 21, and Oölogist, Vol, X, 1892, p. 73.

79-191-(607). Botaurus exilis (Gmel.). LFast BitTern.

Common throughout Southern Michigan: summer resident; "abundant at Ann Arbor and at Grand Rapids" (R. H.Wolcott); "common in Oakland county, where it breeds" (Dr. W. C. Brownell); "common in Monroe Co." (Jerome Trombley); one in collection of C. E. Holmes at Grand Rapids taken in Muskegon Co.; "all Southern Michigan" (A. H. Boies); breeds; nests in June, on the ground. in marshes, on a simple platform of reeds and sedges, often half way up on dead flags, usually over the water, "occasionally in a bush" (Prof. J. W. Simmons); eggs three to six, white with bluish tinge; "nests in Oakland county" (W. C. Brownell, in O. and O., Vol. XVI, p. 32); bird stupid and so, easily caught. 'This species oceurs in Sager's list of 1839.

Subfaily ARDETNA. Herons and Egrets.

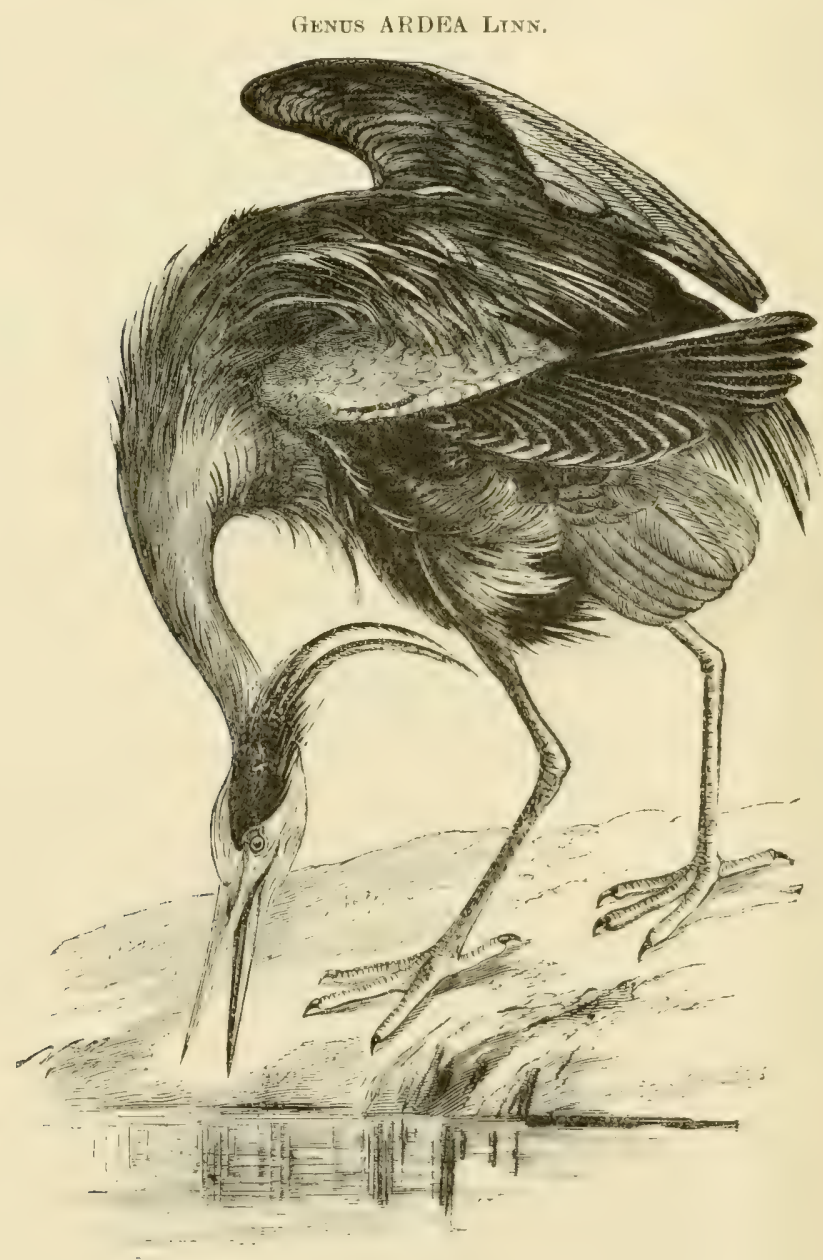

Great Bine Heron. 


\section{\$0-19)-(650). Irdea herodias Linn. *GREAT BLUE HERON.}

Very common; throughout the state; "Grand Traverse county, where there is a heronry" (Dr. M. L. Leach); "common at Iron Mountain" (E. E. Brewster); breeds in colonies; nests in May, in tall trees, near marshes; "sticks in nests sometimes one inch in diamater and tive feet long" (Prof. J. W. Simmons); Dr. W. C. Brownell knows of three heronries near Morrice, Shiawassee county. He says the stench is terrible at nesting time. 'There are often six nests in a tree. The trees, he says, are sure to die: eggs four to six, blue; S. E. White took three nests with five, one with six and one with seven eggs from one tree. May 2, 1881. There was a large heronry just west of Lansing for years. The nests, which were numerous, were in large sycamores which stood in a large marsh. I secured several birds and eggs from this place. Dr. Steere reports heronries in black ash swamps about Ann Arbor. "Heronries are quite conmon in Southwestern Michigan. The birds fish three times daily. I have taken thirty-tive minnows, from two to four inches long, from the stomach of one of these birds" (J. W. Simmons). C. B. Cook took a fish that was twelve inches long and weighed over one pound from the stomach of a Heron. These birds are often very fearless. I have often walked to within a rod or two of a bird before it would fly.

\$1-196-(65s). Ardea egretta Gmel. Americax Egret: Great White Herox: Great White Egrfot.

Very rare: wanderer from the south; A. H. Boies reports it from Lenawee, Hills dale, St. Joseph and Jackson counties; Jerome Trombley reports it from Monroe Co.. where he took one in 1889; "occasionally abundant in July and August, undoubtedly breeds in the state, but where?" (Dr. M. Gibbs); "quite common in late summer in Wayne county, where they are taken half grown, but who knows where they breed: :" (Dr. W. C. Brownell); we had one in our museum taken from Jackson Co.; one taken by J. B. Purdy at Plymouth and now in his cabinet; two taken at Greenville, Mont. calm Co., in 1890 by Prof. Jas. Satterlee; Dr. Atkins does not mention this birct: "breeds in Northern Wisconsin and without doubt in the Northern Peninsula of Michigan (Prof. Ludwig Kumlein); doubtless breeds in Northern Indiana (Butler's Birds of Indiand); this species is given in Sager's list of 1839 . There is a fine specimen in the collection of Mr. Levi Broas, taken in Ionia county.

82-197-(659)). Irolea candidisima Gmel. Snotvy Heron; Littue White Egret.

Very rare; wanderer from the south; "a rare accidental visitor during July and August, does not breed" (Dr. MI. Gibbs).

53-199-(660). Irlea tricolor ruficollis Gosse. Louisiana Heron; Louisiana Egret: LADY OF THE WATERS.

Exceedingly rare; summer wanderer from the South; one specimen reported by E. L. Moseley in the catalogue of the Kent Scientific Institute at Grand Rapids; one reported by A. H. Boies from Lenawee Co.; one reported from northern Indiana (Butler's Birds of Indiana): Dr. M. Gibbs thinks this bird should be omitted from the list.

\section{St-201-66:3). Arlea virescens Linn. GREen Heron: H'LY UP THE CREEK.}

Common; "throughout the State" (A. H Boies); summer resident; two killed on college farm in May; "common at Ann Arbor" (Dr. J. B. Steere); "common in Monroe Co." (Jerome Trombley); "Keweenaw Point" (Kneeland); found nesting at Plymouth hy J. B. Purdy; often quite tame; breeds; nests often in small colonies as does the Great 
Blue Heron, in May; eggs three to six, pale blue. There are several of these, taken in Ionia Co.. in the collection of Mr. Levi Broas.

GeñS NYCTICORAX StepH.

Si, go (66t). Yyeticorax nycticorax navius (Bodd.). Americax Night Herox; Black-crowned Night Heron; Squawk; Night Raven.

Rare; taken on Chandler's marsh north of the college; "southern Michigan" (A. H. Boies); "rare in Monroe Co." (Jerome Trombley); one taken in Lenawee Co. by Dr. W. C. Brownell; one in collection of Levi Broas, taken in Ionia Co.; breeds; nesta in June, in colonies, in trees; C. S. Osborn of Sault Ste. Marie writes me that there is a great colony on Espanore Island at the mouth of St. Mary's River. The Indians and fishermen eat the eggs. He has seen over one hundred nests there in the Birch and Balsam trees, the same nests are used over and over year after year. He adds these may possibly be the Great Blue Heron; eggs four, occasionally five or six; "three or four" (L.S. Foster), bluish; young birds in atumn said to be of good flavor and prized for the table.

\title{
Order Paludicol A. Cranes; Rails, etc.
}

\section{Suborder GRUES. Cranes.}

\section{Family GRUide. Cranes.}

Fine robust birds; feed on rootlets, grasses, grains, reptiles, toads, frogs, etc.

\author{
Genus GRUS PaLL.
}

\section{\$6-204-(668). Frus amerieana (Linn.). Whooping Crane; White Crane.}

Very rare; probably accidental if it occur at all; Covert says "very irregular visitor at Ann Arbor;" "occasionally seen both singly and in flocks of ten or twelve about marshes at Mauchester. Washtenaw county, where in bas been killed repeatedly " (L. W. Watkins); were these not mistaken identifications? "they probably were" (Dr. A. K. Fisher); northern Indiana (Butler's Birds of Indiana).

\section{7-205-(669). Grus canadensis (Linn.). Little Brown Crane.}

"Transient visitor of the Upper Peninsula" (H. Nehrling); "doubtful" (Dr. A. K. Fisher).

\section{S8-206-(670). Grus mexicana (Müll.). *Sandhill Crane.}

Common; southern Michigan, Mar. to Oct.; more common near marshes; Judge J. H. Steere of Sault Ste. Marie.reports this species from the Upper Peninsula; "Keweenaw point" (Kneeland); breeds; Dr. Atkins took a nest at Locke, June 18, 1879; "not rare and breeds $j$ in marshes in Monroe county" (Jerome Trombley); "never seen now in Kalamazoo county" (Dr. M. Gibbs); nests in June on old sedges, on the ground; "nests at Sauger Lake, Shiawassee county" (Dr. W. C. Brownell); eggs two, drab, specked and spotted with brown. We have taken several of these birds here, old and young. which are now preserved in the museum. Mr. L. W. Watkins informs me that they appear often in Jackson county near small lakes, in large flocks of 100 or more, in Oct. and Nov, where they feed extensively on corn, shelling and eating it after it is cut. A young one was reared hy Mr. Watkins until two years of age. They are prized by some 
people for table use. Dr. Brownell writes me that he has known them to be so tame that he could walk to within twenty feet of them; the male often executes a queer dance, and their note is like the rapid stroke of a coarse cow bell.

\section{Suborder Ralli. Rails; Gallinules; Coots, etc.}

Family Rallid R. Rails: Gallixcles. etc.

Feed on reptiles and aquatic animals.

Subfamily RALLINAE. Raths.

GENU RALLUS LiNn.

89-208-(676). Rallus elegaus Aud. King RaIl; Red-Breasted Rail; Fresh Water Marsh Hen.

Rather common; we have it from this place and Saginaw Bay; "Hillsdale Co." (A. H. Boies); "abundant in marshes of Monroe:Co. near Lake Erie" (Jerome Trombley); "breeds at Plymouth, Wayne Co." (J. B. Purily); " a rare transient in Kalamazoo Co., only twice captured to my knowledge" (Dr. M. Gibbs); breeds; nests on the ground; "nests abundantly in Wayne and St. Clair counties" (B. H. Swales); eggs six to twelve, buff, spotted with varying hues of hrown; a young bird in collection of $\mathrm{E}$. S. Holmes, of Grand Rapids, was taken by him near the mouth of the Kalamazoo River. in Allegan Co. Dr. W. C. Brownell writes me that he took ten eggs from a nest. The old bird was very fearless. He has seen the young, mere puffs of black down, leave the nest within a half hour of hatching.

90-212-(677). Rallus vioginianus Linn. *VIRGINIA RAIL.

Very common: Southern Michigan: May to September; "abundant in Southwestern Michigan" (Prof. J. W. Simmons); " abundant about marshes in Monroe Co, near Lake Erie" (Jerome Trombley); "breeds near St. Clair" (B. H. Swales); nests on stems of flags, etc., on the ground; eggs six to twelve, usually seven or eight, creamy white, spotted with small spots of reddish brown. I have found these common here and very common at Saginaw Bay. Mr. L. W. Watkins tells me that they nest very abundantly at Traverse City. This is hunted as a game bird, but is rather inferior for table use: "these birds never commence to sit till a full complement of eggs is laid " IJ. B. Purdy

GENUS PORZANA VIEILL.

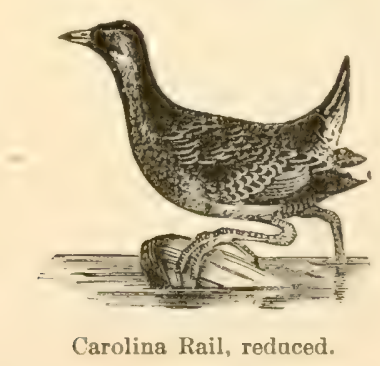

\$1-214-(679). Porzana carolina (Limn.). * Soki; Caroltwa R.te; Crake; Ortulax.

Very common; Southern Michigan: May to Oct.; "abundant in Southern Michigan" (J. W. Simmons); "Looking Glass River near DeWitt" (Dr. G. W. Topping); 
breeds; "not uncommon on Portage Lake, Kewcenaw Point" (Kneeland): " incubation and laying conterminous, so that hatching continues for days" (B. W. Swales); "common at Mackinac Island" (S. E. White); "nests abundantly at Plymouth. Wayne Co." (Jas. B. Purdy); "breeds abundantly in Saginaw marshes" (N. A. Eddy); Mr. Jerome Trombley finds it breeding in Monroe county; I have taken the eggs abundantly at Saginaw; nests in June, on ground, in bog or meadow; eggs five to fourteen, very rarely to twenty, drab, with yellowish tint, darker and with larger spots than those of the Virwinia Rail; often in flocks; excellent game bird, though not good shooting as they are slow to take wing; "I have taken twenty eggs from one nest. The bird commences to sit as soon as the first egg is laid, so the eggs are at all stages of incubation" ( $J$. B. Purdy).

19-215-(680). Porzana unvehoracensis (Gmel.). Yellow Rail; Yellow Crake.

Rare; "probably breeds" (Gibbs' Birds of Michigan); reported in Michigan (Forest and Stream, Vol. XXV, p. 347); see Butler's Birds of Indiana; "summer resident" (Dr. J. B. Steere).

\section{Subamily Gallinulind. Gallinules.}

Genus Gallinula Briss.

93-219-(684). Gallinula galeata (Licht.). *Florida Gallinule.

Common; "Hillsdale Co." (A. H. Boies); Mr. Boies thinks they migrate at night, but not in flocks; "common at Saginaw" (Miles' Birds of Michigan, p 231); " breeds at Plymouth" (J. B. Purdy); " have seen thousands at St. Clair Flats" (Dr. W. C. Browuell); taken at the college; breeds; we have eggs in the museum taken near (irand Ledge: "many nests found in Kalamazon Co." (Dr. M. Gibbs): nests and eggrs as in the follow ing species; a fine table bird.

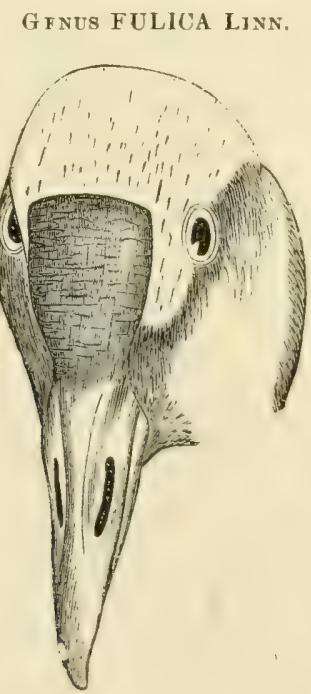

Fruntal Shield of Coot.

94-221-(686). Euliea americana Gmel. *Amertoan Coot; Coot; Mud Hen.

Very common; throughout the entire State: "do not summer in Kalamazoo 
county, but are abundant in migrations" (Dr: M. Gibbs); "common in Upper Peninsula" (E. E. Brewster); "Keweenaw Point" (Kneeland); reported from Mackinac Island; summer months; breeds; nests on the ground, frequently on floating nests; eggs six to twelve, occasionally fifteen, elongate, yellowish drab, spotted with fine dark spots. I have found the nests and eggs very common at Saginaw Bay.

\section{Order Limicolit. Shore Birds.}

\section{Family PHalaropodide. Phalaropes.}

Typical waders; food insects, molluses, crustaceans, ete.

\section{GENUS CRYMOPHILUS VIEILL.}

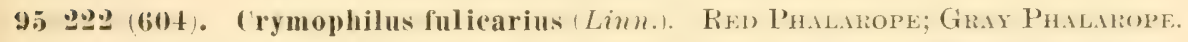

Northern Indiana, rare, probable migrant, probably in Southern Michigan (Butler's Birds of Indiana); em braced in Stockwell's Birds of Michigan; Dr. Steere classifies it among Michigan migrants: Prof. Ludwig Kmmlein writes me that this hird breeds in the Northern Peninsula, which, writes Dr. A. K. Fisher, seems very improbable.

GENUS PHALAROPUS BRISS.

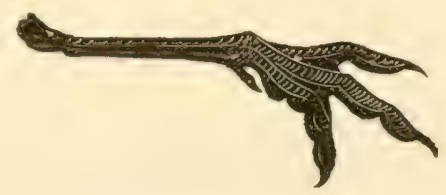

Northern Phalarope, nat. size.

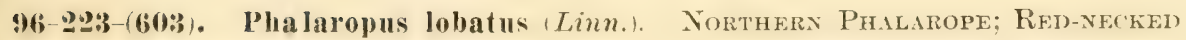
Phatarope.

Exceedingly rare; "rare visitor" (Dr. Morris Gibbs); Dr. J. B. Steere classifies this doubtfully as a Michigan migrant; reenrd by $R$. B. Lawrence of occurence of this bird at Monroe, Michigan, (Forest and Stream Vol. XXV.p. 372); Prof. Ludwig Kumlein writes me that it breeds in northern Wisconsin and presumably in our Northern Peninsula. I think he must refer to Wilson's Phalarope.

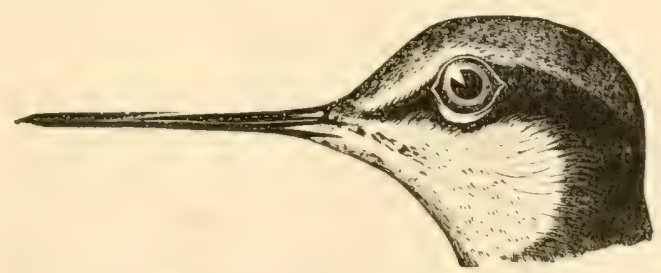

Wilson's Phalarope, natural size.

97-22t-(602). Phalaropus tricolor (Vieill.) Wilson's Phalarope.

"Common, irregular, transient, only oceasionally seen, taken in May and Sept, in Kalamazoo Co." (Dr. M. Gibbs); Dr. J. B. Steere puts it doubtfully among the summer residents; taken by E. E. Brewster at Iron Mountain, May 2, 1890; "Keweenaw Point" (Kneeland); northern counties of Indiana. where it breeds (Butler's Birds of Indiana). 


\section{Family ReCURVIRostrid A. A vocets and Strilts.}

Very long bills and legs; food small molluscs, crustaceans and insects.

Gends RECURVIROSTRA LinN.

\section{5-225-600). Recurvirostra amerieana Gmel. American Arocet.}

"One specimen from Michigan in the Kent Scientific Institute" (E. L. Moseley); one taken by W. H. Collins near Detroit; embraced in Butler's Birds of Indiana.

GeNus HIMANTOPUS BRISs.

99-296-(601). Himantopus Mexicanus (Mull.). Black-NeCked Stilt.

"Rare transient" (Gibbs' Birds of Michigan); of doubtful oceurrence in Michigan. Dr. Steere gives it doubtfully as breeding in Michigan.

\section{Family SCOLOPACidA. Snipes, Sandpipers etc.}

Feed on small aquatic animals. insects etc.; eggs densely spotted, usually pointed at one end; game birds.

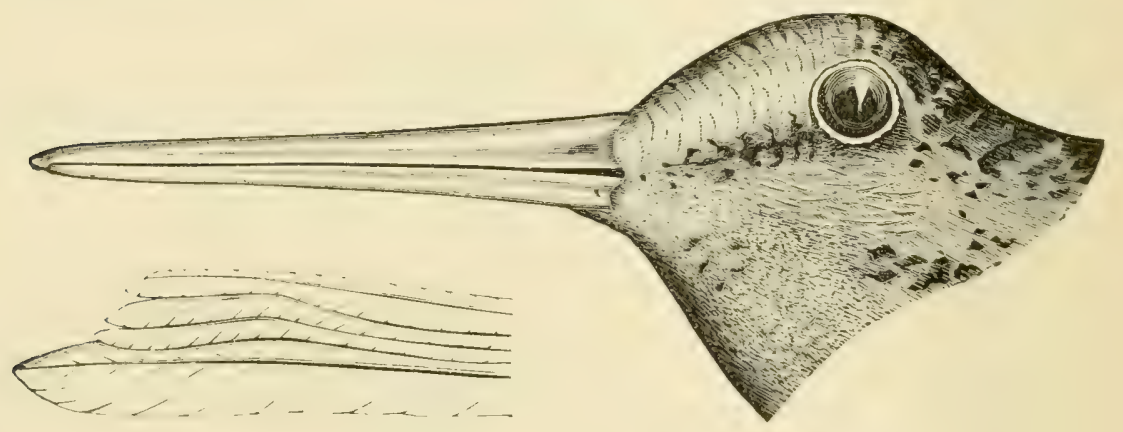

Woodcock, head and outer primaries, natural size.

(ienus PliLOHELA Grat.

\section{0-228-(60)3). Philohela minor (Gmel.). *American Woodcock.}

Common from March, rarely February, to October or November; "occasionally every month of the year" (Gibbs); throughout the state: "formerly very common in Wayne county, but goes as the marshes are drained" (Dr. W. C. Brownell); R. H. Wolcott saw one January 1, 1888, at (irand Rapids, when the snow was one foot deep: reported from Presque Isle Co.; "Grand Traverse Co." (Dr. M. L. Leach); "Mackinac Island" (S. E. White); "Iron Mountain" (E. E. Brewster): "Keweenaw Point" (Kneeland); breeds; nests in April, on the ground in thick brush; eggs four, gray, specked and spotted with dark brown; esteemed as a game bird; taken at the College, October $30,1892$. 


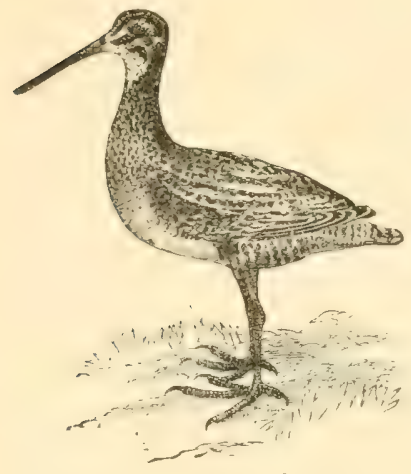

Wilson's Snipe, reduced,

101-280-(608). Gallinago delicata (Ord). *Wilsox's Snipe; Jact Sxipe; Americax SNIPE.

Common in April and October; throughout the state; not very rare in summer; reported in Presque Isle and Muskegon Counties; "Mackinac Island" (S. E. White); "Keweenaw Point" (Kneeland); said to breed: "f found breeding once" (Dr. MI. Gibbs); nests on the ground, in May; eggs four, colors as above; prized as a game bird; "I have seen it, but only as a inigrant" (Dr. W. C. Brownell); somewhat gregarious; this bird, according to Butler, is known as English Snipe, Jack Snipe, Common Snipe and Gutter Snipe.

GENUS MACRORHAMPHUS LEACH.

102-2:32-(610). Macrorhamphus scolopacens (Sau). Red-breasted Sxtpe; Gray Sxipe; Grayback; Gray-Backed Simpe; Lovg-billed Dowitcher; DowITCHER.

Migrant; "a small flock was seen in Kalamazoo county May 21, 1858" (Dr. M. Gibbs); "occasionally seen in Hillsdale and Lenawee counties" (A. H. Boies); doubtfully given as a Michigan migrant by Dr. J. B. Steere; "Keweenaw Point" (K neeland); Prof. Ludwig Kumlein writes me that it breeds in the Northern Peninsula; Davie, p. 111, states that this species breeds on the border of Lake Superior and north; small flocks about marshes; excellent table birt.

\section{GENES MICROPALAMA BAIRD.}

103-23\%-(611). Micropalama limantopus (Bonap.). Strlt Saxnpiper.

"Not rare some seasons near large bodies of water and occasionally taken in the interior" (Dr. M. Gibbs): Dr. J. B. Steere gives it as a doubtful Michigan migrant: "Keweenaw Point" (Kneeland); Prof. Ludwig Kumlein writes me that it breeds in the Northern Peninsula, which seems hardly probable. "Was taken near Lafayette. Ind.. in spring of 1892; first Indiana record “ (A. W. Butler).

Gexus TRINGA LIXN.

104-234-(626). 'Tringa canutus Limn. Kvot; Red-beastev Savdpiper: Robix SNIPE,

"Rare migrant" (Dr. M. Cibbs); "migrant" (Dr. J.13. Steere); inclucled in list of 
Rev. Chas. Fox; May and Sept.; small Hlocks; if this bird occur in Michigan it is very rarely.

10.)-239-(616). Tringa maculata Vieill. Pectoral Sandpiper; "Jack Snipe"; Grass SNIPE.

Very abundant; migrant; "throughout the state" (A. H. Boies); "very common on Lake Erie in Monroe Co" (Jerome Trombley); "taken at Plymouth" (J. B. Purdy); "not rare but decidedly irregular in spring and autumn" (Dr. M. Gibhs); we have taken several here at Lansing; May and Sept.; flocks about marshes; migrant; good game bird; feeds extensively on locusts and other insects.

106-240-(617). Tringa fuscicollis Vieill. White-rumped Sandprer; Bonaparte's SANDPIPER,

"Not common north" (Gibbs" Birds of Michigan); "breeds far north of us" (Dr. A. K. Fisher); Jerome Trombley reports it not rare about Lake Erie; "migrant at Plymouth" (J. B. Purdy); "migrant" (Dr. J. B. Steere); "a rather rare, irregular migrant" (Dr. M. Gibbs); "breeds far north" (H. Nehrling).

107-241-(615). 'Tringa bairdii (Cones). Bard's Sandprer.

This species is embraced in Covert's Birds of Michigan, Cabot's Birds of Lake Superior, and is given by Wheaton as a migrant in Ohio,

\section{5-242-(614). 'Tringa minutilla Vieill. Least SANDPIPfR.}

Common in spring and fall; April and Sept.; "throughout the state" (A. H. Boies); Jerome Trombley reports it very rare in Monroe Co ; "not rare in Kalamazoo Co." (Dr. M. Gibbs); "I see it often in flocks in spring and fall in Shiawassee county, about lakes" (Dr. W. C. Brownell); "migrant at Plymouth" (J. B. Purdy); "migrant in Allegan Co." (S. E. White); Mr. White also reports it at Mackinae Island; taken by E. E. Brewster, May 24, 1891, at Iron Mountain; "breeds in British America" (Dr. A. K. Wisher); "so far as we know breeds north of the United States" (H. Nehrling); "this and the preceding species breeds far north of us" (Prof. J. A. Allen).

109-243a-(624). 'Tringa alpina pacifica Coues. RED-BACKFn SANDPIPER; BLACKbellifin Sandpiper; American Dunlin.

"Migrant, not common, few taken in spring" (Dr. M. Gibbs); "breeds in Sanilac county" (W. A. Oldfield); "one bird taken at Plymouth in the spring of 1891 " (J. B. Purdy); "Allegan county, migrating May 25, 1891 " (S. E. White, O. and O., Vol. 16, p. 9); "migrant" (Dr. J. B. Steere); prized for food.

110-244-(625). 'Tringa fermginea Brünn. Curlew SAxppiper.

Very rare visitor; one taken by the late D. D. Hughes; reported in the catalogue of Kent Scientific institute by E. L. Moseley.

GENUS EREUNETES ILL.

111-246-(612). Ereunetes pusillus (Linn.). Semipalmated Saxppiper.

Common; "throughout the state" (A. H. Boies); migrant; "rare in Monroe Co." (Jerome Trombley); "taken as late as June and as early as August" (Dr. M. Gibbs); "Mackinac Island" (S. E. White); "Keweenaw Point" (Kneeland); "shore of Lake Michigan during August" (Butler's Birds of Indiana). 
GENUS CALIDRIS CUV.

112-45-(697). Calidris arenaria (Limn.). Sanderling.

"Common migrant near Lake Erie" (Jerome Trombley); " common on the shores of the Great Lakes, migrant" (Gibbs' Birds of Michigan); "very common, in flocks, on the shore of Lake Michigan" (Butler"s Birds of Indiana).

Genes Limosi Briss.

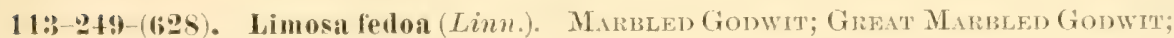
DOF: BIRD: Dough BImD.

Rare; shores of the Great Lakes; May and Sept.; migrant; "taken near Lake Erie by gamesters (gunners)" (Jerome 'Trombley); "not uncommon about Lake Michigan" (Brayton); "migrant" (Dr. J. B. Steere); Davie, p. 117, says it is known to breed in Northern Ohio and Wisconsin; Prof. Ludwig Kumlein writes me that it breeds in Northern Wisconsin, and presumably in our Northern Peninsula, and Mr. H. Nehrling informs me that it breeds in Northern Michigan.

$11+251$-(629). Limo-al liemastica (Limn.). Hudsonax (iomwt; Lessel Doe Bнiр.

Rare; migrant; about Great Lakes; "tuken near Lake Erie by gamesters" (Jerome Trombley); "not very rare about Lake Michigan" (Brayton); given doubtfully by Dr. J. B. Steere as a migrant; "taken at Niles and in Calhoun Co." (D. D. Hughes).

GenUs TOTANUA Bechsteis.

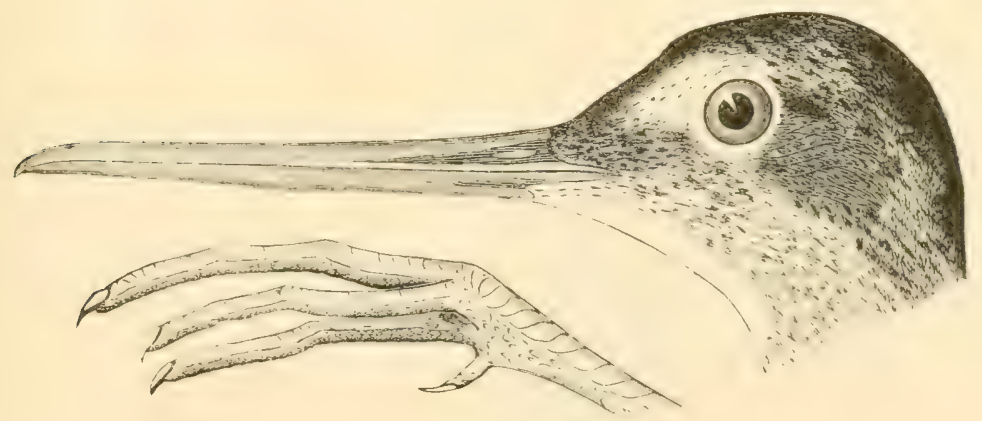

Greater Yellow Leg8, natural size.

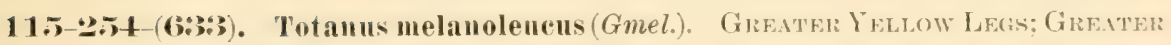
Telitale; Greater 'Tattlem; Stone Snipe.

Abundant; throughout the state; May and Oct.; migrant; "Keweenaw Point" (Kneeland); "common in spring at Iron Mountain" (E. E. Brewster); "common in Monroe Co." (Jerome Trombley); one of our most common long billed migrants; possibly may tarry oceasionally and breed. Prof. Ludwig Kumlein writes me that this species breeds in our Northern Peninsula. Mr. H. Nehrling writes to the same effect. This and the following species are reported by $\mathbf{M r}$. A. W. Butler as breeding rarely in Northern Indiana. 
116-25is-(634). Totauns flavipes (Gmel.). Yellow Legs; Lesser Tattler; YelLOW SHANks.

Common; throughout the state; "abundant in Monroe Co." (Jerome Trombley); "Kent and Allegan counties" (S. E. White); "Iron Mountain" (E. E. Brewster); "Keweenaw Point" (Kneeland); embraced in Cabot's Birds of Lake Superior; common about the college; migrant; occasionally in summer; reported as breeding; "neither this nor the preceding species breeds at Plymouth" (J. B. Purdy); eggs three or four; often oceurs in flocks.

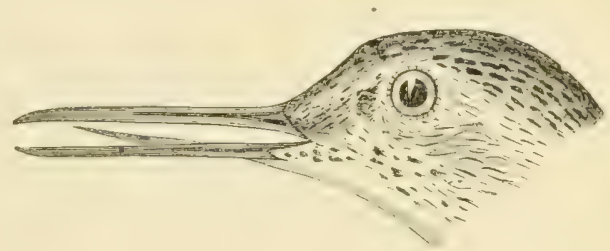

Solitary Sandpiper, natural size.

117-256-(637). Totanus solitarins (Wils.). *Soltaky Sandpiper; Solitaky Tattler; Wagtail; Tip-up; American Green Sandpiper.

Common; May to Sept.; abundant in the marshes about the college; "common about Hillsdale" (F. M. Falconer); " rare in Monroe county but does not breed" (Jerome Trombley); "Mackinac Island" (S. E. White); "Keweenaw Point" (Kneeland); breeds northward; nests on ground; not in flocks. This bird bobs its head instead of tipping its tail.

\section{Genos SYMPHEMIA RAFIN.}

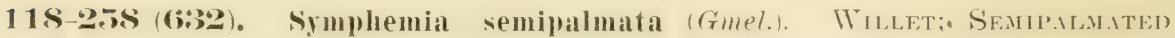 TATTLER.}

Rare; summer resident; admitted doubtfully by Dr. Steere; May to September; Dr. Atkins reports taking this bird at Locke August 13, 1885; Dr. M Gibbs writes me that this bird has been shot at Grand Rapids; "Mackinac Island" (S. E. White); "Keweenaw Point" (Kneeland); table bird.

Geñs BARTRAMIA Less.

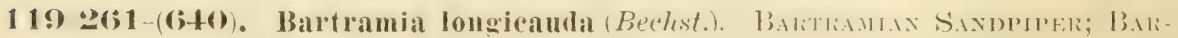
tramian Tattler; Field Plover; Upland Ploter; Pratrie Plover.

Common; A pril to Sept.; reported from Wayne Co.; "Lenawee Co." (A. H. Boies); breeds; "does not breed in Monroe Co." (Jerome Trombley); " nests on ground in Kalamazoo Co., eggs four" (Dr. M. Gibbs); Davie, p. 125, says it is known to breed in several portions of Michigan; nests in May on the ground; eggs four, gray or buff, specked with different shades of brown; excellent table bird. This species is embraced in Dr. Sacer's list of 1839. 
GENUS TRYNGITES CAB.

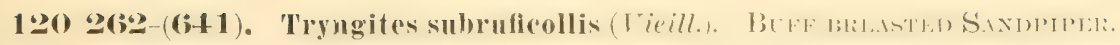

Admitted doubtfully among Michigan birds by Dr. J. B. Steere; "rare, only twice taken, Sept. 17, 1875, and Sept. 14, 1872, not yet observed in spring" (Dr. M. Gibbs); rare; migrant; prized for table; "too rare for a game bird" (Prof. Ludwig Kumlein): "taken near Lafayette, Ind., in the spring of 1892" (A. W. Butler).

GENES ACTITIS III,

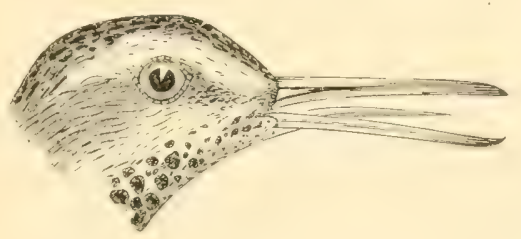

Spotted Sandpiper, natural size.

121-263-(63S). Letitis macularia (Linn.). *Spotted SAxdptper; SANdpiper; Peet-weet; Spotted Tatrler; Wagtail; 'Tip-up; Teeter Thil.

Exceedingly abundant; "throughout the state" (A. H. Boies); April to Oct.; "abundant in Monroe Co." (Jerome Trombley); "Mackinac Island" (S. E. White); "very abundant at Iron Mountain" (E. E. Brewster); "Keweenaw Point" (Kneeland); breeds abundantly; nests in April, on the ground, in the garden, field or woodland; eggs four, yellowish white, with spots of muddy brown. The name, Tip-up, comes from the habit of jerking its tail which it shares with several other species. "The young are beautiful little things, and run about, soon after hatching, in a very sprightly manner" (L. S. Foster).

\section{Genus NUMENIUS Briss.}

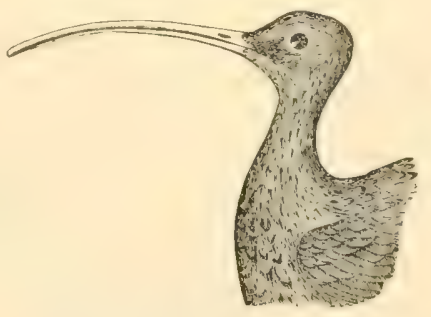

Long-billed Curlew.

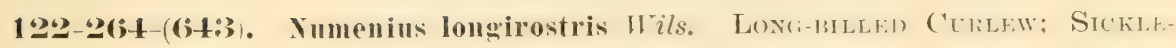
BILLED CURLFiW.

Rare; migrant; "rare near Lake Erie" (Jerome Trombley); admitted doubtfully among Michigan migrants by J. B. Steere; "breeds in the Upper Peninsula" (H Nehrling); valuable table bird.

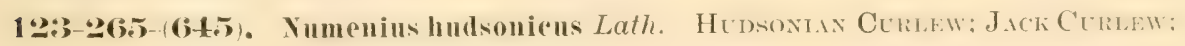
Short-billed Curlew.

Very rare; "only two taken to my knowledge" (Gibbs' Birds of Michigan); "never seen in Monroe Co." (Jerome Trombley); admitted doubtfully, by Dr. J. B. Steere among Michigan migrante. 
124 266-(it6). Numenius borealis (Forst.). Eskmo Curlaw.

Exceedingly rare; one specimen reported by Dr. M. Gibbs; admitted doubtfully by Dr. J. B. Steere; Benj. Syke, of Kalamazoo, records one as late as Oct. "28; migrant: gregarious; about marshes; excellent for table.

\section{Family CHARADRIIDE. Plovers.}

Feed on insects, crustaceans. molluses, ete; eggs usually dark and spotted: some species valuable as game birds.

GENUS CHARIDRIUS LIXN.

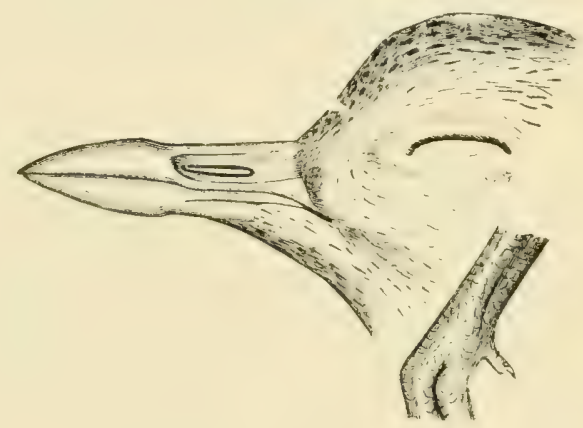

Black-bellied Plover, natural size.

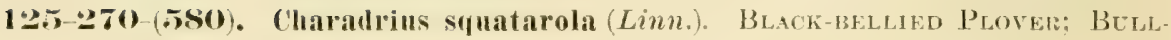
HFAD.

Rare; migrant; A. H. Boies reports it from Lenawee and Hillstale counties; "Monroe Co." (Jerome Trombley); "once as late as Oct. 20 " (Dr. M. Gibbs); "Keweenaw Point" (Kneeland); "a regular migrant alonæ the Great Lakes, Superior included" (Prof, Ludwig Kumlein).

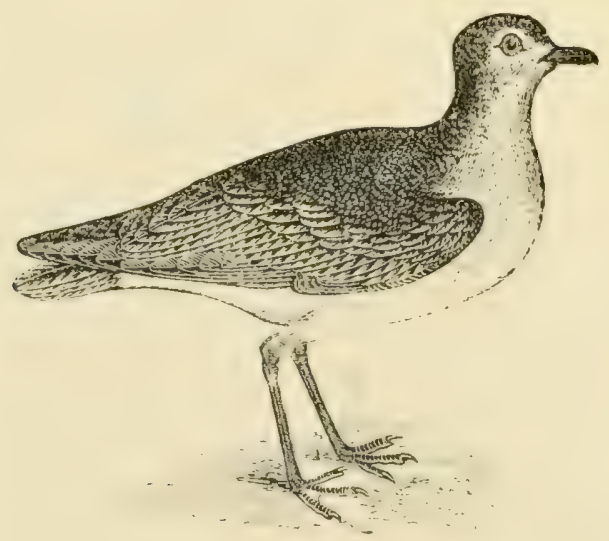

Golden Plover, in fall or winter, relnced. 


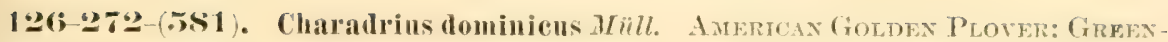
BACK.

Common; throughout the state; April and Oet.; migrant. This bird is not men. tioned by Dr. H. A. Atkins, but it has been taken here repeatedly; Mr. Jerome Trombley reports it as a common migrant near Lake Erie; "large flocks appeared at Lansing in Sept., 1890, and many were killed" (J. E. Nichols); taken at Plymouth by J. B. Purdy; "Keweenaw Point" (Kneeland); "common transient in the autumn, but rarely seen in spring. often in large flocks, most abundant about Sept. 25, in Kalamazoo Co." (I)r. .I. (Gibbs).

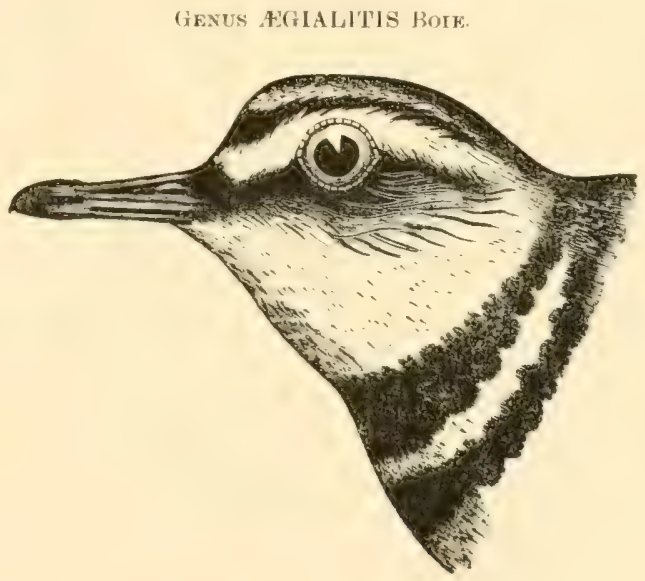

hilltepr, naural size.

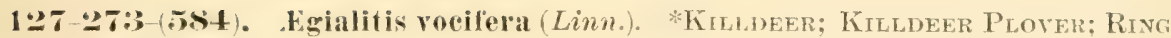
Plover.

Very abundant; throughout the entire state; common from March to Dec.: often seen in winter; valuahle as a destroyer of insects; our most common plover; frequents gardens, pastures and roadsides; "Mackinac Island" (S. E. White); "oceasional at Iron Mountain" (E. E. Brewster); breeds: nests often as early as March, on the ground. usually on a knoll, in gardens and pastures; eggs four, yellowish white, spotted with dark brown. Dr. Brownell writes me that the eggs are diways arranged in the form of a cross with the small or pointed ends towards the center.

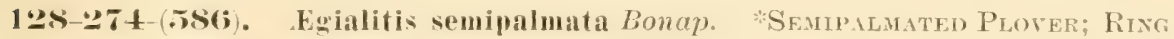
Plover: Rive: Neck.

Common; migrant; May and Sept; Jerome 'l'rombley has taken it in Monroe Co.: "Upper Peninsula" (A. H. Boies); "Keweenaw Point" (Kneeland); taken by J. B. Purdy at Plymouth; "common at Morrice " (Dr. W. C. Brownell); said to be a summer resident north. We have taken this bird here at the college in early spring. Dr. Atkins reports taking one at Locke Aug. 19, 1884; " northern part of Indiana" (Butler"s Birts of Indiana).

139) 277 -(J5t). Egialitis meloda (Ord). Pibing Plover; Piping Ring Plover.

kather rare; migrant; "rare migrant in Monroe Co." (Jerome Trombley); " I have shot it as a migrant in Allegan Co." (S. E. White); embraced in the lists of Hughes. Boies. Covert and Gibbs. These notes may refer to the next suecies. 


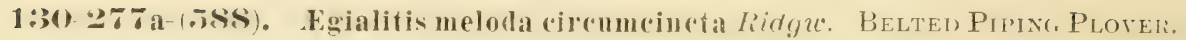

"Migrant, not common. Summer resident northward" (Butler's Birds of Indiana); "common summer resident along the shore of Lake Michigan" (Dr. Brayton). Prof. A. W. Butler thinks this species more common in Northern Indiana than the preceding. I have no positive eridence of the occurence of this bird in our state.

\section{Family aPHRIZID E. Sưf Birds axn Turnstones.}

Feed on crustaceans, shell fish. etc.

Subfamily ARENARIiNe. Turistones.

Genos ARENARI. Briss.

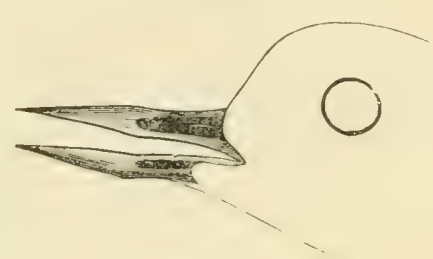

Turnstone, natural size.

$1: 31$-2S:3-(59S). Arenaria interpres (Linn.). TuRNstone.

"A rare irregular migrant in Kalamazoo Co., taken once as late as May 2, showing it to be a spring migrant" (Dr. M. Gibbs); "common along Lake Michigan" (Brayton); included in Sager's list of 1839.

\section{Order Gallin 2 . Gallinaceous Birds.}

'These birds are granivorous and possess strong claws for scratching. They include most of our domestic birds.

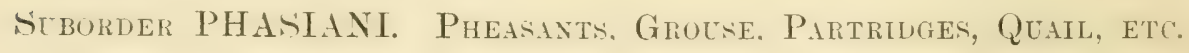

Family tetraonide. Grolse, Partridges, etc.

Feed on insects, grass, seeds, etc.; fine game birds; flocks; generally polygamous; do little injury, and are of immense economic importance.

\section{Scbanily Perdicinde. Partridges.}

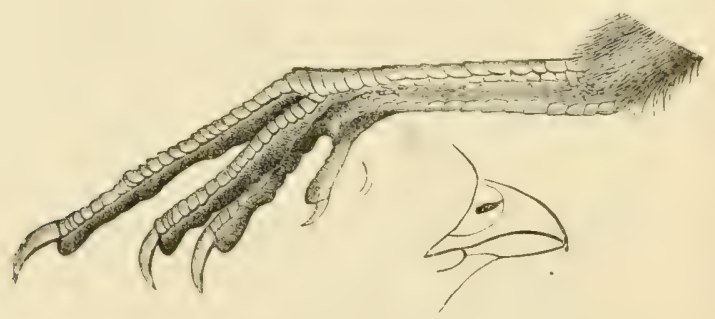

Quail, natural size: 
132-2S!)-(571). Colinus virginianus (Limn.). *Bob White; Quail; Partridge.

Very common; throughout the southern peninsula; all seasons of the year; large flocks; very tame; frequent lawns and barnyards in winter; "never seen at Iron Mountain" (E. E. Brewster); "not generally found much north of Petoskey, though two were seen on Mackinac Island. September, 1890" (S. E. White); "Keweenaw Point" (Kneeland); breeds; nests in summer, occasionally as late as September. on the ground; eggs white, pointed at one end, numerous; J. B. Purdy has taken

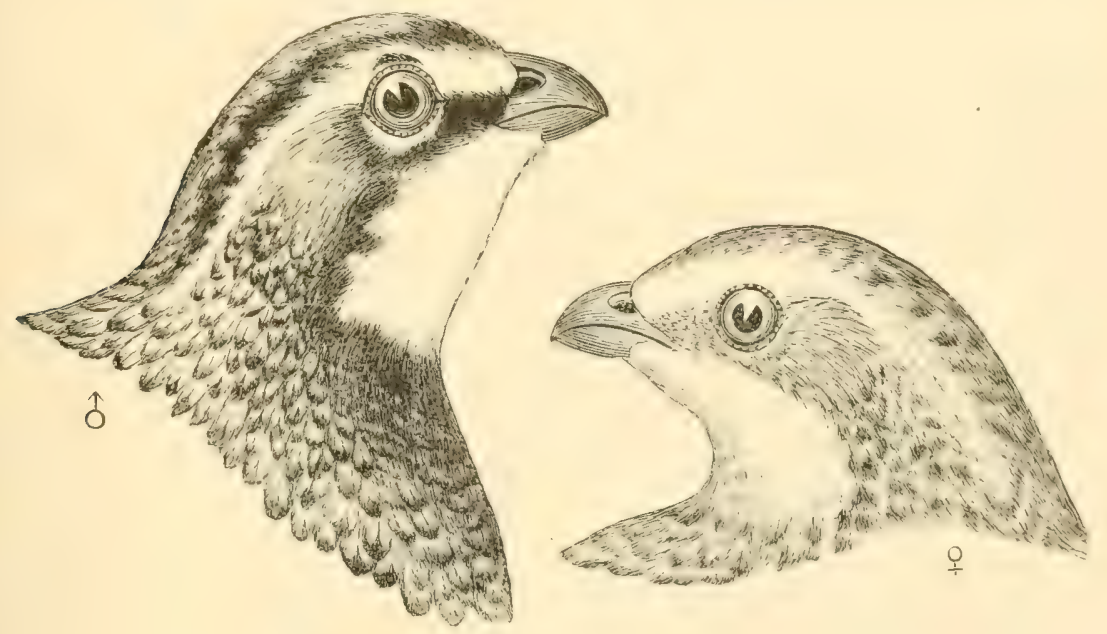

Quail, male and female, natural size.

twenty-one eggs from a single nest; "I took thirty-eight eggs from one nest" (Dr. W. C. Brownell); prized as a game bird; very useful in destroying insects, seeds of weeds, etc.; this species has been temporarily protected in our state; "so excellent id friend should be permanently protected" (Prof. Jas. Satterlee); "more common in Monroe county than it was ten years ago" (Jerome Trombley). The name partridge is used south and east.

\section{Genus DENDRAgapus Elliot.}

133-295-(555). Jendragapus canadennis (Limn.). Carada Grouse; Sprure Partriden.

Common north; I have it from Ionia Co.; taken in winter; "formerly very abundant in all the scrub pine thickets in the northern counties, very tame and stupid. and so, easily exterminated" (C. J. Davis); "does not inhabit the shore counties of Northwestern Michigan, I only find it near Higgins and Houghton Lakes" (Dr. M. L. Leach); "common at Au Sable" (N. A. Eddy in O. and O., Vol. IX. p. 41); "Upper Peninsula" (A. H. Boies); "rare on Keweenew Point" (Kneeland); "occasional at Iron Mountain " (E. E. Brewster and S. E. White); "not found in Kalamazoo Co., but common north" (Dr. M. Gibbs); Dr. W. C. Brownell took a straggler in Washtenaw Co. in the fall of 1887; included in Sager's list of 18:39, and Cabot's of 1850; breeds in the northern part of the state. I have reports of its breeding in the Northern Peninsula; "I know that it breeds in Northern Michigan and the Northern Peninsula " (Prof. Ludwig Kumlein); "common in the Gogebic region" (H. Nehrling.) 
GENUS BONASA STEPH.

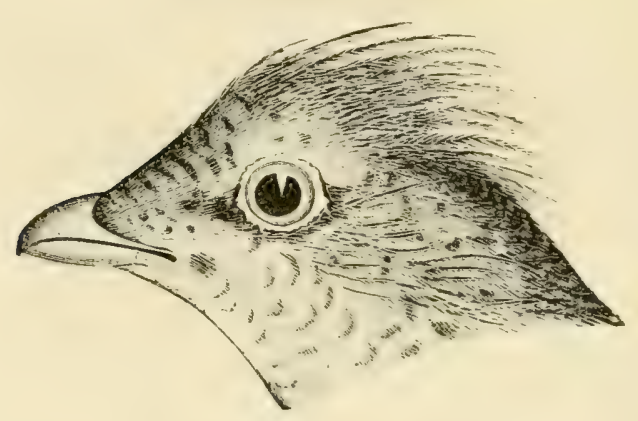

Rutfed Grouse, natural size.

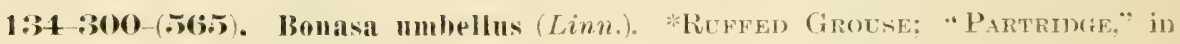

Michigan; "PheAsAxт," south.

Very common, though decreasing in number; throughout the entire state; "still abundant about Ann Arbor" (Dr. J. B. Steere); "common at Au Sable" (N. A. Eddy); "common at Iron Mountain" (E. E. Brewster): "very common at Keweenaw Point" (Kneeland): breeds; nests in .June, on the ground, nests said to be of ten concealed by logs, etc.; "I never find them so" (Prol. Ludwig Kumlein); "always covers egrs with leaves before leaving the nest " (J. B. Purly); I have always found the nests of eggs entirely exposed; eggs six to fifteen, usually ten to twelve, creamy white to buff. occasionally spotted with tine reddish dots; seen through the year; excellent game bird; occasionally fly into houses in autumn through windows. This bird is known by the drumming of the male with its wings, which may be heard for a long distance. This bird eats berries, nuts, especially beech nuts, and insects. In the autumn it eats many grasshoppers and such caterpillars as the oak caterpillar. Edema albifrons. My son. A. B. Cook, thinks that they nerer cover their eggs, except as they accidentally sweep the leaves over the egoss, as they take wing. 'The drumming, for which this birt is noted, is probably callsed by the wings striking the air.

GeNes LAROPUS Brish.

1:35-301-(56s). Lagopus lagopus (Limn.). Wrlow Parmigax.

Reported from Upper Peninsula (See Gibbs" list of Michigan Birds); "habitat Minnesota " (Birds of Minnesota, Hatch. 1892, p. 162); "Keweenaw Point" (Kneeland): "south to northern New York" (Jordan); pure white in winter.

GENUS TYMPANUCHUS GLOAER.

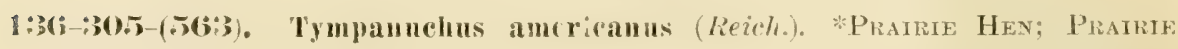
Chicken: P.innated Grouse.

Quite common; formerly very rare here, butcommon in the southwestern part of the State; "formerly abundant, but now extinet at Ann Arbor" (Dr. J. B. Steere); "extinct in Monroe county for more than thirty years" (Jerome 'Trombley); "very common in Southwestern Michigan" (Prof. J. W. Simmons); more frequent in prairie region; seen through the year; breeds; nests in June, on the ground; nest said to be often concealed by leares, etc.; egrs eight to fourteen, gray, often specked with brown; destroys many insects; excellent game bird; Dr. Atkins found a nest in June. 1879; he reports them very common at Locke in January, 1878; embraced in Sager"s list of 1839; "should he carefully protected, as it is a valuable friend to the farmer" (Dr. A. K. Fisher). 


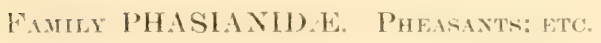

Large fine game birds, gregarious, polygamous.

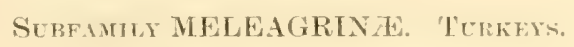

(GENUS MELEAGRIS LINS.

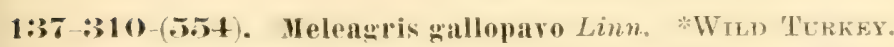

Once very common; "none olsserved in Upper Peninsula" (A. H. Boies); formerly large flocks were seen on the college farm; now extinct except north; " extinet in Montcalm county" (Prof. Jas. Satterlee): "I do not believe there is a turkey north of an east and west line passing through Houghton Lake" (Dr. M. L. Leach); all seasons of the year; breeds; nests in May, on the ground; eggs nine to twelve, occasionally as many as eighteen, creamy white, spotted with brown; "eggs reamy white thickly spotted with small specks of rusty brown and umber" ( $H$. Nehrling); excellent for table; Jerome Trombley reports an old bird, with brood. in Monroe county, in 1888; J. B. Purdy writes me that young were taken in Warne in 1888, and eggrs in Kent county in 1891. It is an interesting fact that this species is omitted in the excellent list of the late Dr. A. Sager. A number of tine turkeys were caught here a few years ago in a log pen into which they passed through a hole dug in the ground, 'underneath one side, as they picked up corn which was placed in this trench. Once in the pen, they only looked up. and so they were successfully caged.

\title{
Order colaumbei. Pigeons.
}

\author{
Fimily COLUMBIDA. Pigens and Doves.
}

These birds are granivorous, as well as insectivorous.

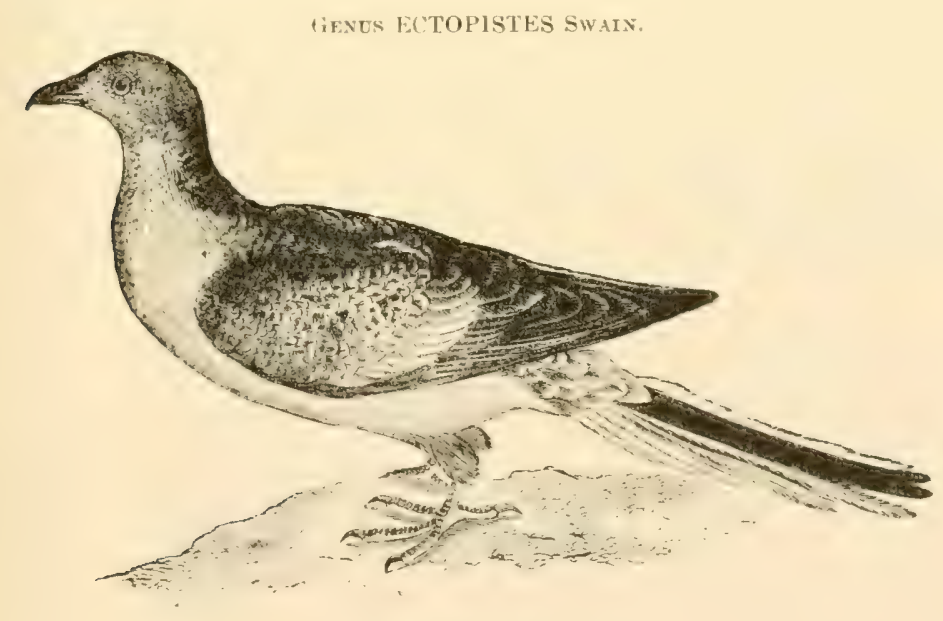

Wild I'igeon, rednced.

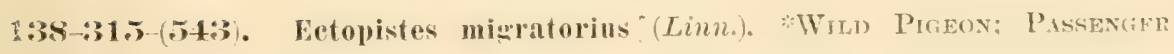
Pifeon.

Once very common, now equally rare; as a boy I saw immense flocks in Shiatrassec 
Co., so large as to nearly cloud the sky; "became extinct at Ann Arbor about 1875 " (Dr. J. B. Steere); "I have seen flocks of from 30 to 80 in Kent Co." (S. E. White); "became extinct in Monroe Co. in 1885" (Jerome Trombley); "last seen at Morrice in 1881, when I shot 52" (Dr. W. C. Brownell); reported from Benzie and Presque Isle counties; "Mackinac Island" (Dr. M. Gibbs); "seen at Keweenaw Point as early as May 4" (Kneeland); March to Oct., sometimes taken in winter; formerly bred in all parts of the state, abundantly north; large breeding roosts formerly at Shelby, Mich. (Forest and Stream, Vol. XIV, pp. 231, 232); nest and eggs similar to those of the next species. except that this one nests in colonies and "lays one egg at a sitting" (Dr. M. Gibbs); valuable for table; destroys grain. For interesting description of this bird in Michigam see article by Mr. Wm Brewster, in Auk, Vol. VI, Oct., 1889, p. 285; and for description of its breeding and migration in Michigan, see article in Scientific American, Vol. XLII, 1883, p. 343 .

GENUS ZENAIDURA BONAP.

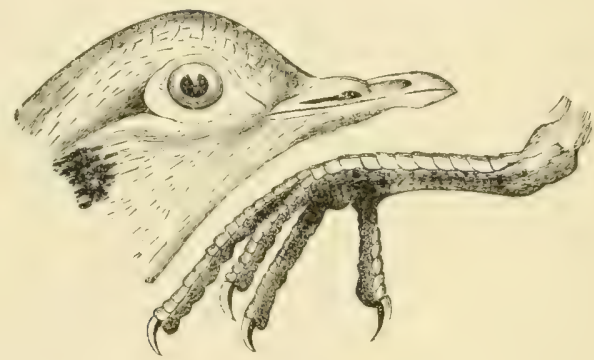

Carolina Dove, natural size.

1:39-316-1544). Zeuaidura macroura (Linn.) *Molening Dore; Carolina Dore.

Very common; throughout the state; found in all months, but rare in winter; during this very cold winter of 1892-3 several of these birds have been seen daily about my corn crib; "Mackinac Island" (S. E. White); "from May to Sept." (J. B. Purdy); b reeds; nests in May, R. H. Wolcott found a nest July 18, 1892, in low bushes, in low trees, in orchards, on fences, rarely on the ground, often close to house, while the pigeon prefers dense woods; eggs two, white. These birds are often seen along the roadside and in barnyards.

\section{Order raptores. Birds of Prey.}

Strong, carnivorous, with hooked beaks and strong talons.

\section{Suborder SARCORHAMPHI. American Vultures.}

\section{Family Cathartide. American Vulteres.}

Birds of Prey and carrion eaters; valuable as scavengers.

GeNUS CATHARTES ILLJeER.

140-325-(537). Cathartes aura (Linn.). Turkey Vulture; Turkey Buzzard.

Very rare; E. L. Moseley, who has lived twenty summers in Branch county, has 
never seen one in Michigan; F. M. Falconer writes me "not very rare in the spring of 1892, at Hillsdale"; "throughout the state" (A. H. Boies); embraced in Fox's list of 1853 of Birds about Detroit; Mr. L. W. Watkins tells me that they are common in Jackson and Washtenaw counties every year; they are never seen here; Dr. Atkins makes no mention of them; C. J. Davis, Lansing, Michigan, has one in his collection taken at Fow lerville, Livingston Co.; "becoming more common each year" (Dr. M. Gibbs); Prof. J. W. Simmons has taken them in Van Buren Co.; Geo. D. Sones, of Fresno, Cal., writes me that he took them at Ross, Kent Co., in 1836 and 1887; "more common than formerly in Wayne Co." (J. B. Purdy); "rare in Monroe Co., where a nest with two young was taken at Petersburg, in June, 1890" (Jerome Trombley); "Mr. Elmer Durfee took female and two eggs in Kent Co. in 1892, in the large end of a hollow tree in a swamp" (Dr. W. C. Brownell); "breeds in Wayne and Kent counties" (J. B. Purdy); "occasional in Kent Co., two eggrs were taken by me in 1391, in Allegan Co., the only ones taken in the state" (S. E. White).

\section{Suborder Falcones. Vultures; Falcons; Hawis, etc.}

Fanily Falconide. Vultures; Falcons; Hawks, etc.

Diurnal birds of prey; feed on mice, insects and other birds; like the owls, beneficial, as determined by extensive research by United States government investigators; most of the species feed almost exclusively on mice and insects; (See "Hawks and Owls of the United States in their Relation to Agriculture," by Dr. A. K. Fisher, Department of Agriculture, Washington, 1893); eggs, like those of the owls, nearly spherical, usually specked.

\section{Subfimly ACCIPITRINA. Kites; Buzzards; Hawhs, etc.}

Gexus ElANOIDES V'reill.

\section{1-327-(493). Elanoides forfieatus (Linn.). Swallow-tailed Kite.}

Said to occur in Michigan; probably an accidental straggler, as the bird is a great wanderer; reported in our fauna by the late D. D. Hughes; a pair shot in Monroe Co., June 19, 1882 (see Bulletin of Nuttall Ornithological Club, Vol. VIII, Oct., 1832, p. 250). The late Mr. Collins secured a specimen near his home in De troit.

Genus Elanus Satig.

142-3:S-(492). Elanus leucurus Vieill. *White-TAILed Ktte; Black-SHouldered KITE.

Very rare; Dr. H. A. Atkins reports taking it at Locke, Ingham Co.; Mr. S. E. White writes me that he took one in Kent Co.. April 10, 1858, and has the specimen; Mr. A. B. Covert reports taking two specimens in Washtenaw Co.; "extremely doubtful, are the specimens preserved?" A. K. Fisher.

GeNus ICTINIA Vieile.

143-329-(491). Ietinia mississippiensis (Wils.). Mississipti KtTe.

Said to occur in Michigan; exceedingly rare; the late Hon. D. D. Hughes reported one specimen from Cass Co.; Prof. A. W. Butler gives it as a rare visitor in Northern Indiana. 
Genus CIRCUS LACEPEDE.

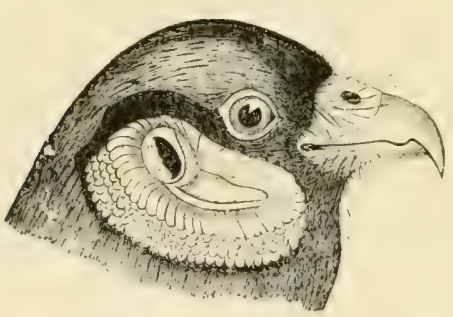

Ear parts of Circus.

14t:3:31-(489). Cireus hudsonins (Linn.). *Marsh Hawk; Modse HaWK; HaRrizi.

Abundant; throughout the State; summer resident; "common in Monroe county" (Jerome Trombley); "Mackinac Island" (S. E. White); "Keweenaw Point" (Kneeland); breeds; nests on the ground; eggs three to six, greenish white, often spotted with brown. We have taken the nests and young at this place. "This valuahle bird should be protected by law" (J. B. Purdy).

GENOS ACCIPITER BHsS.

14.7:3:32-(4!)4). Accipiter velox (Wils.). *Shatr-shinNed HaWk.

Common; throughout the state; April to August; oceasional in winter; "Iron Mountain" (E. E. Brewster); "Keweenaw Point" (Kneeland); "Mackinae Island" (S. E. White); probably breeds; Dr. M. Gibbs writes me that it is not known to breed in Kalamazoo county; nests in trees high up from the ground; eggs three to five, rarely seven; "a single bird has been known to lay seventeen eggs in succession" (A. W. Butler), bluish or greenish white, fpotted at large end with brown. This is one of our most common small hawks, it is brave and takes toll of the fancier; "this and the following species are the only two common hawks that are injurious" (Dr. A. K. Fisher); "too small I think to be classed as a chicken hawk" (Prof. Ludwig Kumlein); "I have seen it kill chickens" (S. E. White).

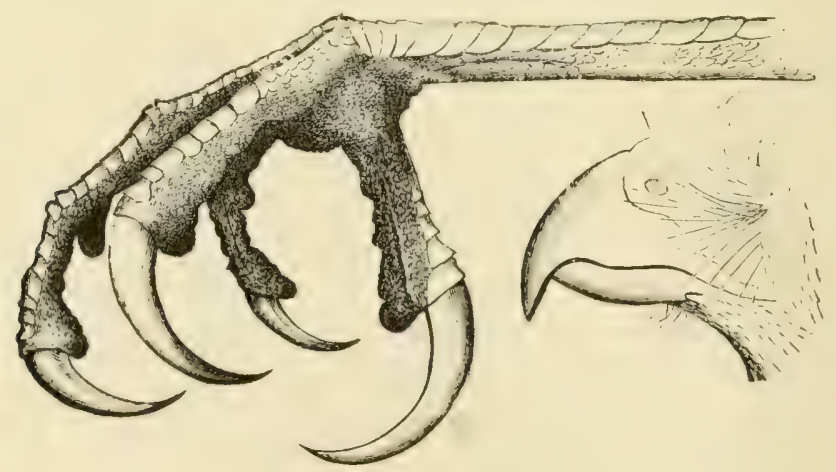

Cooper's Hawk, natural size.

146-333-(495). Aceipiter cooperi Bonap. *Cooper's Hawk; Chicken Hawk.

Very common; throughout the state; May to October; E. L. Moseley shot one at Grand Rapids March 27, 1886; " Mackinac. Island". (S. E. White); "Keweenaw Point" 
(Kneeland); breeds; nests in May in trees; "took set ol tive egges at Plymouth, April "2t. 1892 " (J. B. Purdy); "breeds commonly in Kent county" (S. L. White); F. M. Falconer took two eggs from a nest in the spring of 1892 . and later took five from the same nest: "K. R. Willhelm of Kalamazoo elimbed to nine nests from twenty to forty-five feet high in one day and secured twenty-three eggs" (Dr. M. Gibbs); eggs two to six, undistinguishable from those of the Marsh Hawk; free to visit ponltry yards. I have known one to dart down and carry off a chicken within a rod of where I stood; Dr. A. K. Fisher. than whom there is hardly better authority, writes me: "'The true Hen Hawk. quite injurious, destroys pigeons and poultry, probably the only common harmful hawk." Prof. A. W. Butler writes me to the same effect. It is sometimes known as blue hawk, blue darter (South) and blue-tailed hawk.

147-3:34-(4!6). Accipiter atricapillus (Wils.). American Gosmawh.

Occasionally seen in summer; more frequently in winter; more common north, where it breeds; Dr. M. Gibbs writes me that it surely breeds in Wexford Co.; one in our museum from Berrien Co.; taken by A. H. Boies in Hillsdale Co, and by S. E. White in Kent Co.. and Mackinac Island; one killed north by Elmer Durfee; Mr. Levi Broas has a fine one in his collection taken by him in Ionit Co.: "this and the two preceding species are the most harmful of the hawks, the others rarely prey upon poultry" (Prof. J. A. Allen).

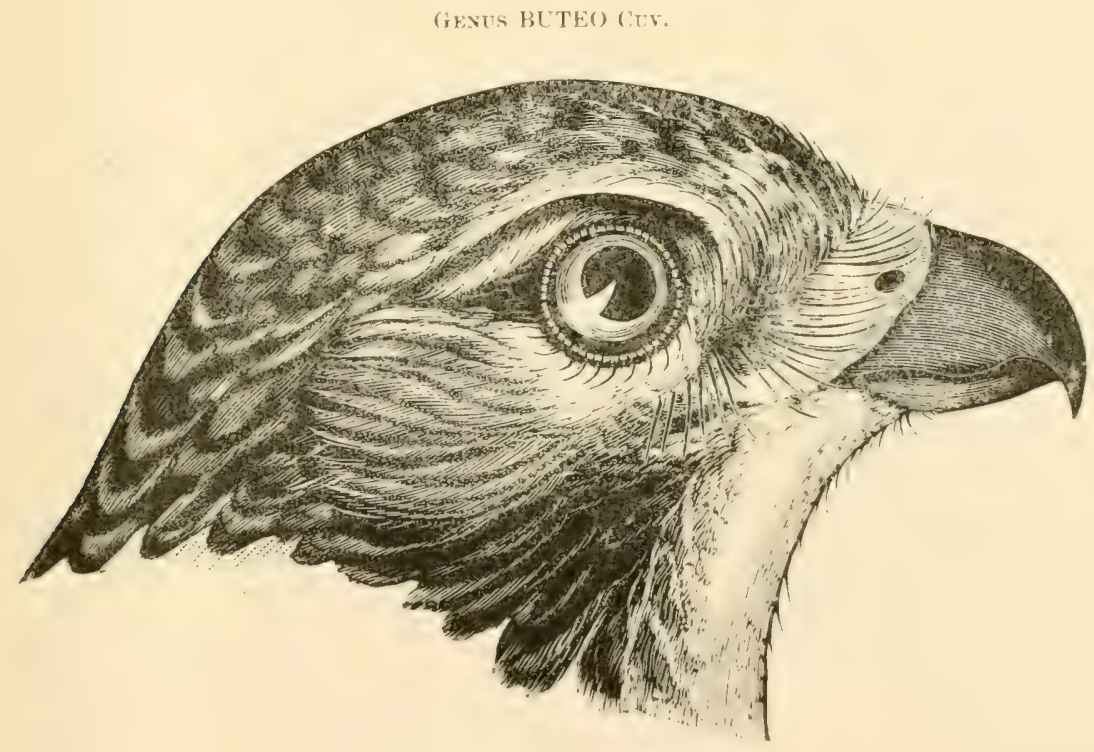

Red-tailed Hawk, natural size.

145-337--516\%. Buten horealis (Gmel.), *Red-tarted Haw: Red-TaILed BuzZARD; HEN HAWK.

Very common; throughout the state; "Iron Mountain" (E. E. Brewster); "Mackinac Island" (S. E. White); "Keweenaw Point" (Kneeland); this and the next species are among our most common hawks; "this species and the Red-shouldered are very valuable in destroying noxious rodents and insects, and when hard pressed, take a few of 
the less active fowls" (Dr. A. K. Fisher); seen soaring high up in the air; "less common than the next species at Morrice" (Dr. W. C. Brownell); foun\} at all months, " but not common in winter, indeed much less so than the next species" (E. L. Moseley); breeds; Mr. K. R. Willhelm has taken over 150 eggs in Kalamazoo Co. in four years; nests in March and April, in high trees; nest very larga; eggs two to four, white, often soiled, nearly always spotted with reddish brown. This is the common Hen Hawk of the farmers.

149-339-(520). Buteo lineatus (Gmel.). *Red-shouldered. Hawk; Redshouldered Buzzard; Hex Hawh.

Very abundant; throughout the state; March to Sept.; occasional in winter; "Mackinac Island" (S. E. White); general and nesting habits and eggs much as in the preceding species except the eggs are a trifle smaller and more coarsoly spec'zed; $B$. Swales has taken a set of five eggs; K. R. Willhelm has robbed over ninety nests in Kalamazoo Co. Dr. A. K. Fisher states that both of these species are our friends; Prof. Ludwig Kumlein writes me that this and the last species rarely take poultry, if they ever do.

\section{0-312-(523). Buteo swainsoui Bonap.. Swaixsox's Hawh.}

Exceedingly rare; one killed by A. H. Boies in Hillsdale Co ; one killed in Genesee Co., where it was identified by Dr. MI. Miles (Mileș' Birds of Michigan, p. 231); Mr. Jerome Trombley writes me that he has taken the nest and eggs in Monroe Co.; " the food of this bird is largely composed of locusts" (L. S. Foster).

\section{1-343-(524). Buteo latissimus (Wils.). Broad-Wraged Hawk.}

Common; summer resident; "common at Ann Arbor" (Dr. J. B. Steere); "Hillsiale and Lenawee counties" (A. H. Boies); "a retired bird, found only in deap woods" (Dr. M. Gibbs); E. E. Brewster thinks this species rather common at Iron Mountain; "Mackinac Island" (S. E. White); breeds; Dr. Gibbs took the eggs near Kalamazoo. May 27, 1875; nests and eggs taken by Jerome Trombley at Petersburg, in Monroe Co., where it is not uncommon; S. E. White writes that he took nest and four eggs in Kent Co., June 25, 1891: Dr. A. K. Fisher writes that it destroys myriads of locusts. These hawks sometimes occur in flocks of several hundred during autumnal migrations" (Prof. Ludwig Kumlein).

\section{GENUS ARU'HLBUTEO BREHM}

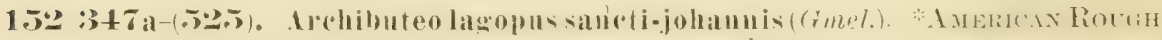
LEGGED HAWh.

Rare; Sept. to May; Dr. Atkins reports finding a nest in Locke, May 18, 1876. which was doubtless an error; "they do not breed in the United States" (Di. A. K. Fisher); "one specimen taken at Plymouth in fall of 1892 " (J. B. Purdy); "one taken by Mr. Dempel, of Hillsdale, April 7, 1892" (F. M. Falconer); "Mackinac Island and Kent Co." (S. E. White); "Keweenaw Puint" (Kneelant); "Iron Mountain Oct. 20. 1892" (E. E. Brewster); "rare and only in winter in Monroe Co." (Jerome Trombley); Prof. Ludwig Kumlein, of Milton College, Wisconsin, writes me that he has taken one nest in Dane Co., Wisconsin, and one other nest in that state with two young in it, but he thinks this species not a regular breeder in the limits of the United States. This species is embraced in Dr. A. Sager's list of 1839. "Feeds almost entirely on small rodents" (Dr. A. K. Fisher). 
Genus AQUila Briss.

15:3 349-(53:2). Aquila chrysaëtos (Linn.). Golden Eicile.

Rare; one in our museum taken in Clinton county, and one from Northern Michigan; "taken occasionally in Southern Michigan, a rare straggler from the north" (Dr. M. Gibbs); one taken in Kalamazoo Jan. 1, 1892 (R. F. Judson in O. and O.. Vol. XVII, 1892. p. 9); A. H. Boies reports it from the Upper Peninsula and from Hillsdale county; "not uncommon in the Gogebic region" ( $H$. Nehrling); Jerome 'Trombley has seen it at the mouth of the Raisin River in Monroe county; "taken in Kalamazoo county" (Dr. M. Giblos); probably nests in the northern part of the state.

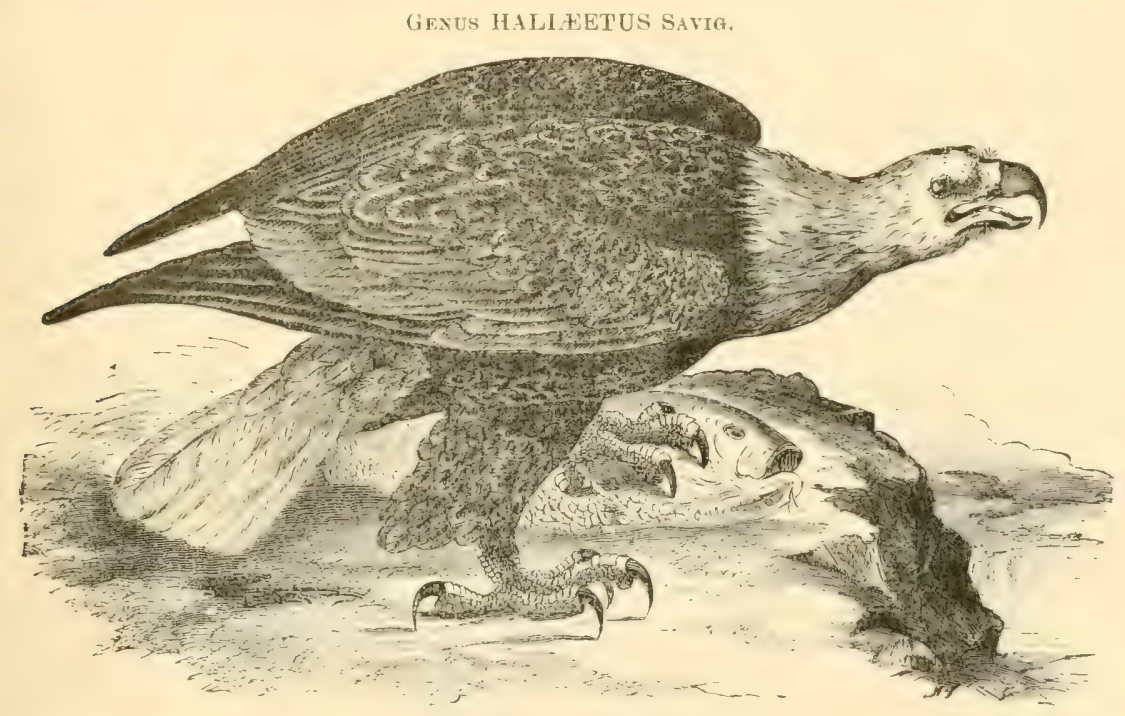

Bald Eagle, reduced.

154-352-(534). Halizetus lencocephaius (Linn.). *Bald Eacile.

Not rare, especially in the uninhabited regions of the north; "rare in Momroe Co., but a pair have their nest on the Raisin River near its mouth" (Jerome Trombley); all months of the year; two in our museum killed in January, one from Ingham and the other from Shiawassee county; found common at Bay City by N. A. Eddy (O. and O., Vol. IX, p. 4); "Grand Traverse county" (Dr. M. L. Leach); "common in the Upper Peninsula" (S. E. White); "quite common in the Gogebic region of the Northern Peninsula" (H. Nehrling); breeds; "a pair of young taken from nest at Byron in spring of 1892" (J. B. Purdy); "breeds in Cheneaux Islands, Mackinaw straits" (Dr. M. Gibbs); "breeds on Keweenaw Point" (Kneeland); nests in tall trees, "using the same nest year after year" (C. J. Davis); eggs two, rarely three, nearly spherical, dirty white. The late Prof. W. K. Kedzie secured two of the young here in 1868, which he reared to maturity; "I have caught them alive in steel traps mounted on top of poles" (S. E. White). We have only these two eagles in United States. The young differ so widely from the adult that many suppose that we have sereral species.

\section{SubFamlit FaLCONINA. Filcons.}

Geves Falco LiNs.

155-354a-(49S). Falco rusticolus gyrfaleo (Linn.). Grofalcon; Jerfalcon.

"Said to have been taken in the state in winter" (Gibbs" Birds of Michigan); 
"probably on Keweenaw Point" (Kneeland); "south to the United States in winter" (Jordan). Dr. Gibbs writes me that he should retain this, as his authority was the late Dr. G. B. Wilson.

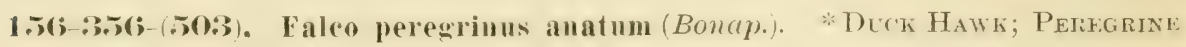
FALCON.

Rare; taken by Dr. Atkins at Locke, Nor. 2, 1881; throughout the state; "rare at Ann Arbor" (Dr. J. B. Steere); "one specimen taken in Monroe Co. in 1886" (Jerome Trombley); "two Michigan specimens in the collection of the Kent Scientific Institute at Grand Rapids" (E. L. Moseley); Davie says it has been known to breed in Michigan; rather common northward, and doubtless found in spring, summer and fall but not in winter; " breeds at Michigamme" (Davie, p. 187); "breeds on southern shore of Lake Superior" (Prof. Ludwig Kumlein). This species is given in Sager's list of 1839.

157-357-(505). Falco columbarius Linn. *Pigeon Hawk.

Rare; throughout the state; "occasional at Ann Arbor" (Dr. J. B. Steere); all seasons, or at least a summer resident; "taken at Grand Rapids" (E. L. Moseley); "Monroe Co., rare" (Jerome Trombley); "Mackinac Island" (S. E. White); "Keweenaw Point" (Kneeland); taken by Mr. A. H. Boies in Hillsdale Co., where he has seen several; taken by Dr. Atkins in February, March and April; "breeds" (Dr. M. Gibbs); "breeds in Northern Peninsula" (Prof. Ludwig Kumlein); "may breed in northern counties, but even this is doubtful" (Prof. J. A. Allen).

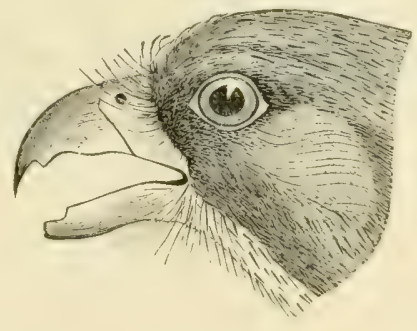

Sparrow Hawk, natural size.

158-360-60s). Falco sparerius Linn. *American Sparrow Hawh.

Very abundant; throughout the state; April to Sept.; "Mackinac Island" (S. E. White); "Keweenaw Point" (Kneeland); "occurs at Iron Mountain, Upper Peninsula" (L. W. Watkins); "very common at Iron Mountain". (E. E. Brewster); breeds; nests in holes in trees which are usually decayed; eggs four to seven, nea rly spherical reddish white, spotted with brown; a beautiful, but bold "and useful friend" (A. K. Fisher); kills immense numbers of mice and insects. and occasionally birds and chickens; "lives chiefly on insects" (Prof. J. A. Allen); "I doubt if this bird ever kills chickens" (Prof. Ludwig Kumlein); "I have never seen it kill a chicken, it should be protected by law" (J. B. Purdy).

\section{Subamity PANDIONINA. Ospreys.}

Genus P.iNuion Savig.

$1.59: 36+1.530 \%$. Pandion haliäns carolinensis (Gmel.). *Anfrean Osprey; Fish Hawk.

Rather rare; "not rave at Ann Arbor" (Dr. J. B. Steere); "rare in Monroe county 
but breeds near the lake" (Jerome Trombley); throughout the entire state; bird and young taken at the college in 1868; taken by Dr. Atkins at Locke, April 5, 1872;" occasional in the northern counties about the inland lakes" (C. E. Davis); "only seen at Plymouth in fall and winter, saw three at one time on an apple tree, February, 1892" (J. B. Purdy); in manuscript list of Fox; "common on Mackinac Island, several seen every day" (S. E. White): "common at Les Cheneaux Islands" (E. B. Boise); "Iron Mountain" (E. E. Brewster); "Keweenaw Point" (Kneeland); breeds; nests in trees, on the ground. on rocks, etc.: nests often very bulky; eggs two to four: food fish.

\section{Suborder st'riges. OWts.}

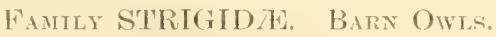

Feed on rats, mice, insects and birds; very valuable.

$$
\text { (iENUS STRIX LINN. }
$$

160-365-(461). Strix pratincola Bonap. American Barx OrL.

"Rather rare, resident" (Gibls' Birds of Michigan): we have never seen it here: Dr. J. B. Steere informs me that the same is true at Ann Arbor: "Sault Ste. Marie" (Chas. Bendire, Smithsonian Contribution to Kinowledge, Vol. XXVIII, p. 32.5); one Michigan specimen reported in the catalogue of the Kent Scientific Institute by E. L. Mcseley, who writes me that though common at Sandusky, Ohio, they are exceedingly rare in Michigan; recorded by A. H. Boies in 1875. A. B. Covert in 1878 and by Dr. M. Gibbs in 1879: "has been known to breed in Tippecanoe and Clinton counties. Ind.," (A. W. Butler).

\section{Famey BUBONIDAj. Common Owls.}

Nocturnal birds of prey; feed on rats. mice, insects and birds; do great good. Elaborate investigations by government experts prove them to be exceedingly valuable. See "Hawks and Owls of the United States in Relation to Agriculture," by Dr. A. K. Fisher, Department of Agriculture, Washington, 1893. Eggs, like those of hawks, short and spherical. "All owls, with the possible exception of the great homed owl, and nearly all hawks should be protected by law" (J. B. Purdy).

Ginus Asio Briss.

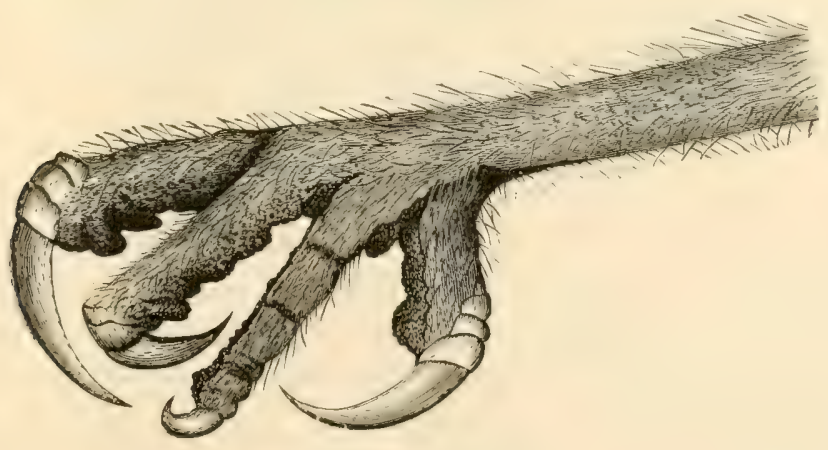

Raptorial foot of an Owl. 
161-366-(172). Isio wilsonianus (Less.). *Amertcan Long-eared Owl.

Rather rare; all seasons; "found in Hillsdale" (F. M. Falconer); A. H. Boies has taken several in Hillsdale County; "at Ann Arbor" Dr. J. B. Steere); "only seen at Plymouth in fall and winter" (J. B. Purdy); "rare in Kent County where it breeds" (S. E. White; "is common and breeds in Monroe County" (Jerome Trombley); breeds; " nests with five eggs taken in Wayne County in A pril and May" (B. H. Swales); "several nests taken about Kalamazoo" (Dr. M. Gibbs); nests bulky, in trees; "often lays in nests of other birds" (Samuels); eggs three to six, sometimes seven; we have taken this owl and its nests and eggs here at the college, Dr. Atkins took a specimen at Locke; one taken near Owosso November 25, 1892; "this is an efficient mouser" (A. K. Fisher).

162-367-(173). A sio accipitrillus (Pall.). Short-eared Owl; Pratrie Owl.

Rather rare; "common in Hillsdale County" (F. M. Falconer); "not rare at Ann Arbor" (Dr. J. B. Steere); "taken not infrequently in Lenawce and Hillsdale Counties" (A. H. Boies); "Kent county " (S. E. White); all seasons; breeds; "nests on the ground" (Samuels). We have taken one of these birds here at the college. Dr. Atkins does not report it.

Gexus SYRNiUM Savig.

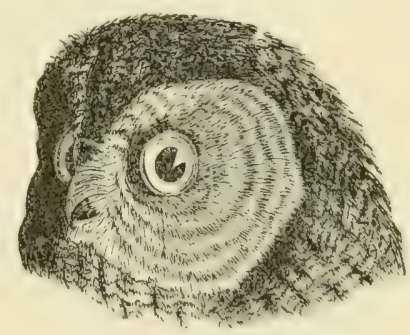

Barred Ow1, reduced.

16:3-3(iS-(176). Syruium nebulosum (Forst.). *Barken Owz; Hoot Owd.

Very common; throughout the State: found at all seasons; "Grand Traverse Co." (Dr. M. L. Leach); "our most common owl " (Geo. D. Sones): "Mackinac Island" (S. E. White); "Keweenaw Point" (Kneeland); "common at Iron Mountain" (E. E. Brewster); breeds; nests in holes in trees in March and April; eggs three, white, spherical; "Mr. A. Durfee has taken eggs from same nest for seven years" (Dr. W. C. Brownell). Like the Great Horned Owl, occasionally visits poultry houses. I think this more common than the Great Horned Owl, and, next to the Screech Owl, our most common species. Mr. A. B. Purdy finds that this owl will sit on her empty nest for some time after all eggs are taken.

(BENUS SCOTILTERYA SWAIN.

164-370-(474). Scotiapteryx cinerea (Gmel.). Great Gray OWL.

"Rare straggler from the north" (Dr. M. Gibbs); "Keweenaw Point" (Kneeland). I have zever heard of this bird here. Mr. A. H. Boies informs me that he has noticed it in the Upper Peninsula. It is said to be partially diurnal. Brayton gives it as a rare winter visitant in Northern Indiana. 
GENUS NYCTALA BREHY.

16.5 :37-(4\$2). Nyctala tengmalmi richardsoni (Bondp). Richardons ()we.

This bird has been taken in Ohio, Illinois and Wisconsin. and it is very likely in our Northern Peninsula fauna; "probably in winter" (J. A. Allen).

166-36:-48:3). Vyetala aealica (Gmel.). *SAW-twhet OWL; ACadran OWL.

hare; found at all seasons; "rare now, but more common twenty years ago in Monroe County" (Jerome Trombley); "in swamps, at Ann Arbor, rare" (Dr. J. B. Steere); "not very rare in Lenawee and Hillsdale Counties" (A. H. Boies); "Keweenaw Point" (Kneeland); breeds; nests in hollow stumps, etc.; "nests in Oakland County" (W. C. Brownell in O. and O. Vol. XVI, p. 22); eggs four to seven; our smallest owl; I have this from Washtenaw and Ingham Counties. Dr. Atkins took one at Locke, Dec. 18, 1882, which weighed less than two ounces; Prof. James Satterlee has taken this bird at Greenville, Montcaim County. Mr. S. E. White has taken it in Allegan County, and Mr. Gilbert White has captured the downy young in Kent County; "breeds in Northern Indiana" (A. W. Butler).

(iENUS MEGASCOPS KIAUP.

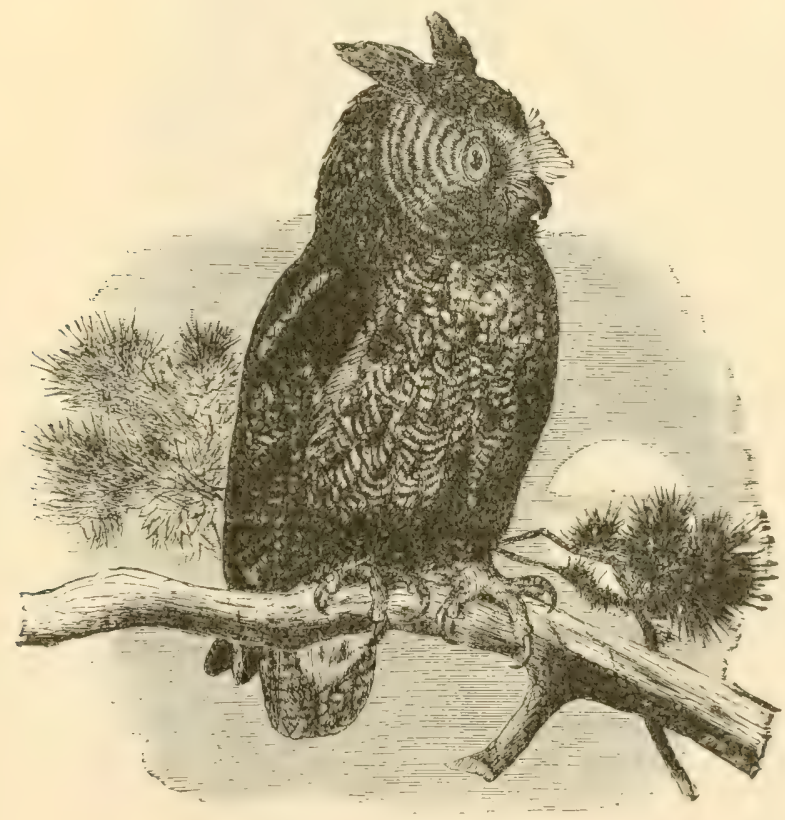

Sicreech $\mathrm{OW}_{\mathrm{w}}$, reduced.

167-:37:3-(465). Megascops asio (Linn.). "Screfch Owl; Mottlen Owl.

Our most common owl; "very common at Ann Arbor" (Dr. J. B. Steere); found all months of the year; in summer, it whines and moans in shade trees about our houses, in winter we take it in out-buildings where it remains by day; "Upper Peninsula" (A. H. Boies); "Keweenaw Point" (Kneeland); breeds; nests, in May, in hollow trees; eggs four to six, frequently eight, rarely nine, white, subspherical; eats insects and English Sparrows; beneficial; "food, principally mice" (Prof. Ludwig Kumlein). 'There are two 
phases of color, the gray and the brown, the gray is usually the most common, though occasionally the reverse seems true.

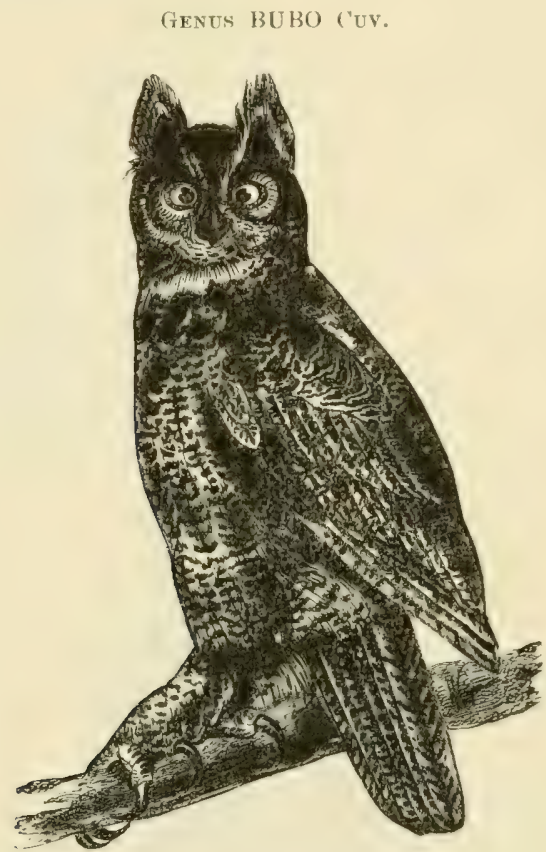

Great Horned Owl, much reduced.

16S-375-(46:2). Bubo virginianus (Gmel.). *Great Horned Owt; Hoot OwL.

Very common; throughout the state; all seasons; "occurs at Republic, Upper" Peninsula" (L. W. Watkins); "common in Monroe Co." (Jerome Trombley); "rare at Ann Arbor" (Dr. J. B. Steere); "common in Grand Traverse Co." (Dr. M. L. Leach); "Keweenaw Point"(Kneeland); E. E. Brewster reports it from Iron Mountain; breeds; nests in February and March, in thick forests, in trees, nests of other birds especially. or in hollows of trees; "Frank Judson, of Kalamazoo, has found many nests, sometimes with a simgle egg, usually two, but in rare cases three" (Dr. M. Gibbs); F. M. Falconer found a nest Feb. 25, 18:1, and the April following the Red-tailed Hawk occupied the same nest, each bird had occupied this nest in turn for years; eggs one to four, white, nearly spherical; two eggs taken at Plymouth March 20, 1892, by J. B. Purdy; this owl is often taken in hen houses; it should not be confused with the long-eared owl, though it is often called by that name; it is nearly as common here as the Screech and common Barred Owls. "Very valuable in rabbit infested districts, though sometimes troublesome in destroying poultry" (Dr. A. K. Fisher). One taken at the college, May 9, 1893, had entered a poultry house and destroyed three chickens. It was a large female and had only minute eggs in the ovaries. 
169)-375:1-(463). Bubo virginiaums subareticus (Hoy.). Westerix Hornen OWL.

Rare; "without doubt, as Mr. A. 13. Covert says, rare or accilental in - Michigan, as it occurs in Wisconsin and Northern Illinois" (A. W. Butler). It is possible that this bird and also the Arctic Horned Owl may be taken in Northern Michigan. Coues includes in No. $46: 3$ this and the sub-species arcticus.

GENUS NYOTEA S'TEPH.

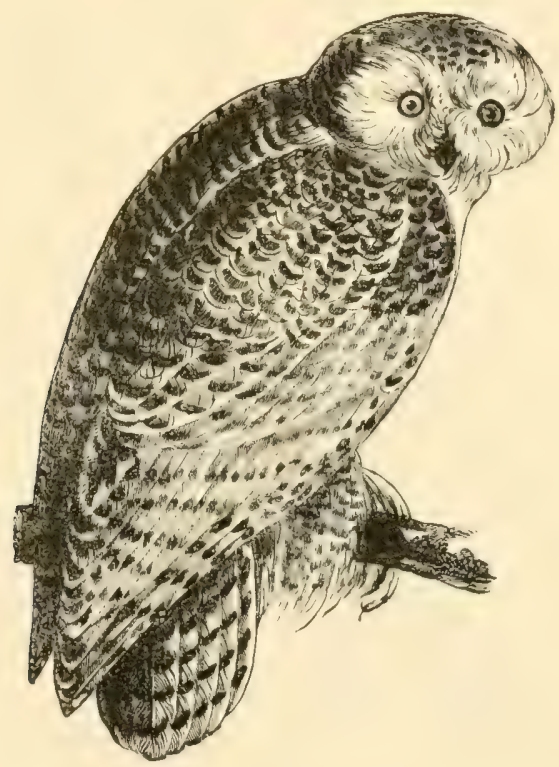

Snowy Owl, redinced.

170 :37(;-(479)). Nyetea nyctea (Linn.). *SNowy OWL; Whrte OWL.

Common in wiuter; throughout the state; ten taken in December at South Haven, by E. H. Lockwood (American Field Vol. XXVII); we have taken several at this place; unlike other owls, it is amiable in continement; Mr. L. W. Watkins killed one at Manchester, Mich., that had pounced down on a hen in broad daylight and killed it; "common in Grand Traverse county" (Dr. M. L. Leach); "Monroe county in severe winters" (Jerome 'Trombley); "very rare in winter, one taken in St. Joseph county in 1892 " (A. H. Boies); "Keweenaw Point" (Kneeland); "food, mammals, birds, batrachians, fish, and molluses" (L. S. Fisher).

(TENUS SURNIA DUMERIL.

171-375a-(480). Surnia ulula eaparoch (Müll.). American Hawk Owd.

"Rare winter visitor" (Gibbs' Birds of Michigan); Mr. A. H. Boies has taken one in St. Joseph county; "south to Wisconsin" (Jordan). We have never seen this bird here; "Eagle River on Keweenaw Point" (Kneeland); embraced in the lists of Dr. Sager (1839), Cabot's Birds of Northern Peninsula, St. Ignace (1850), Dr. Miles (1861), and Covert's Birds of Washtenaw County (1881). 


\section{Order PSIT'TACI. Parrots; Macaws; Paroquets, etrc.}

Mostly tropical birds, with very hooked beaks, and claws for climbing.

$$
\text { Family PSITTACIDA. Parrots. }
$$

Feed on cockle bur, tender twigs, blossoms and young fruit of the orchard trees, fruit and grain.

\section{Genus CONURUS KuHL.}

172-35:-(460). Conurus carolinensis (Limn.). Carolina Paroquet.

Exceedingly rare; A. H. Boies believes he saw a pair at Mallory Lake in Hillsdale county in 1860; "remarkable but hardly possible" (Dr. M. Gibbs);. Dr. Robert Ridgway informs me that the National Museum collection has a specimen labeled from Michigan. Prof. Ludwig Kumlein writes me that he has shot one specimen in Jefferson county, Wisconsin, and that his father, the late 'Thos. Kumlein, saw them in Wisconsin in the forties; if it occur in Michigan it comes as a very rare straggler from the south; usually seen in flocks; for a very interesting article on this bird see Auk. Vol, IX, Jan., 1892, pp. 49-56, whereProf. A. W. Butler gives a very complete monograph on the distribution of this species. It is stated (p. 50) that both Audubon and Wilson reported this bird from Michigan. which is certainly conclusive.

\section{Order Coccyges. Cuckoos.}

These are climbing birds with curved, not hooked beaks.

\section{Suborder CUCULI. Cuchoos. \\ Famil CUCULidA. Cuchoos.}

Feed on insects, even eating hairy caterpillars; very beneficial.

Subfamlit COCCYGinde. Ceghoos.

Geño COCCYZús Vieill.

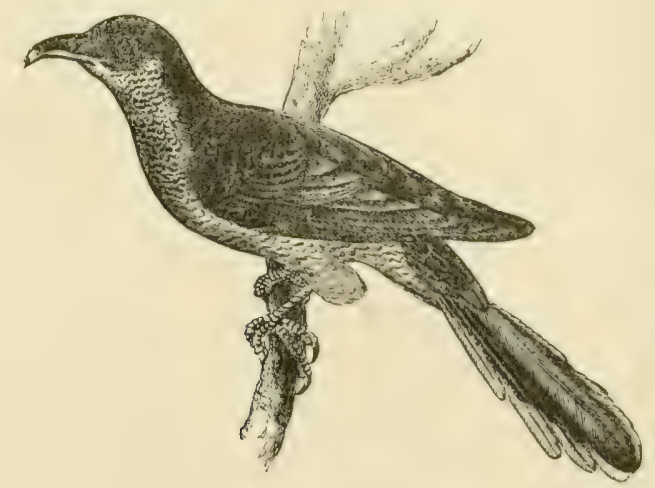

Yellow-billed Cuckoo, reduced. 
17:3-387-(4:20). Coccyzus americanus (Linn.). * Yellow-BILled CuCkoo.

Formerly rather rare at this place, but now quite common; "less common in Monroe County than the next species" (Jerome Trombley); "common in Kalamazoo Co." (Dr. M. Gibbs); S. E. White reports this species very rare in Kent County; easily mistaken for the Black-billed Cuckoo; Dr. Atkins reported finding eggs of this species in the nest of the Black-billed Cuckoo; "the time of incubation of eggs, in the same set, very variable" (S. M. Falconer); breeds: I find both this and the next species nesting commonly about the college grounds; nests in trees; eggs two to six, usually four; like those of the next species only larger and a little lighter colored. We see that these birds are some like the European Cuckoo in the habit of using each others nests, which may account for the varying period of incubation.

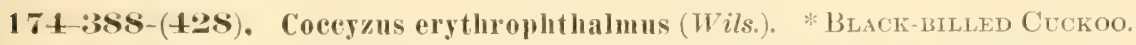

Formerly quite common at this place, but now rather rare; May to August; "very common in Kent County" (S. E. White); "very common in Kalamazoo County" (Dr. M. Gibbs); breeds; nests in June, in orchards, bushes or trees; eggs four to six, laid at intervals, blue; feed on hairy caterpillars. I have often seen them eat the Teut Caterpillar-Clisiocampa americana. Forbes found (see Report of Michigan Hort.' Soc., 1891, p. 204) that seventy-five per cent of the food of birds of this species which he examined consisted of canker worms

\section{Suborder ALCYONES. Kingeishers.}

Strong billed birds; food almost entirely fish.

\section{Family ALCEDINID无. Kingfishars.}

Feed on fish; found about streams; kill fish by using them as a hammer; utter a whirring note as they fly along the creek or river.

Gexus CERYLE BoIE.

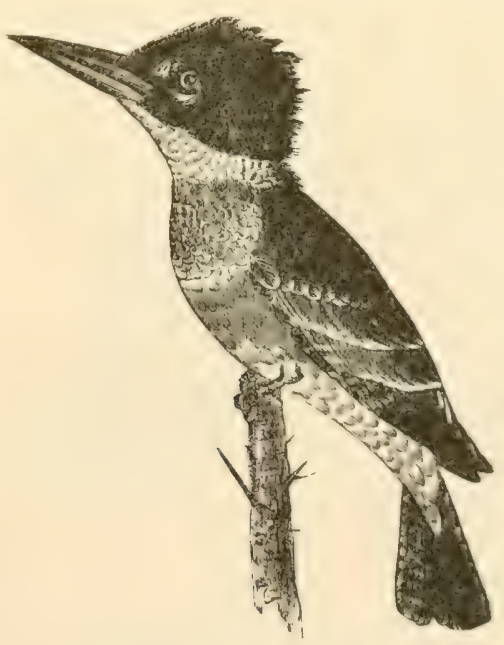

Belted Kingfisher, reduced. 


\section{5-390-(42:3). Ceryle alcyon (Linn.). *Belted Kingaisher.}

Very common; throughout the entire state; April to Sept.; "Grand Traverse Co." (Dr. M. L. Leach); "Mackinac Island" (S. E. White); "Keweenaw Poin t" (Kneeland); "occasionally in mild winters in Monroe Co." (Jerome Trombley); "common all through

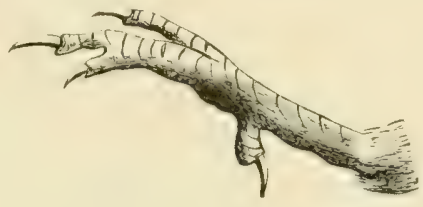

Syndactyle foot of Kingtisher.

the Upper Peninsula" (L. W. Watkins); " common at Iron Mountain" (E. E. Brewster); breeds; nests, in a hole four to eight feet long in banks; "nests sometimes in hollow trees" (Dr. W. C. Brownell); nests along the banks of the Red Ce:lar River on the college grounds; eggs six to eight, white.

\section{Order PICI. WoOdpeckers.}

Climbing birds, with chisel like bills and barbed tongues.

\section{Family PICIDA. Woodpeckers.}

Peck holes in wood in search of insects; food insects, fruit and grain; very beneficial; nest in holes formed in trees; eggs snow white.

\section{Gexus DRYOBATES Bolf.}

176 -39:3-(4:3i3). Dryobates villosus (Linn.). * The HaIRY Woodpecker.

Very common; throughout the state; found at all seasons; "Grand Traverse Co." (M. L. Leach); "Mackinac Island" (S. E. White); "Keweenaw Point" (Kneeland); "common at Iron Mountain" (E. E. Brewster); breeds in all parts of the state, but more common north; male aids in incubation; eggs four to five, clear white; eats borers and other insects. I have made a close study of this and the following species, and I feel certain that they are of great economic value to the pomologist. The bands used in destroying coddling moth pupæ are of ten fairly riddled by these birds in quest of the insects which the bands conceal.

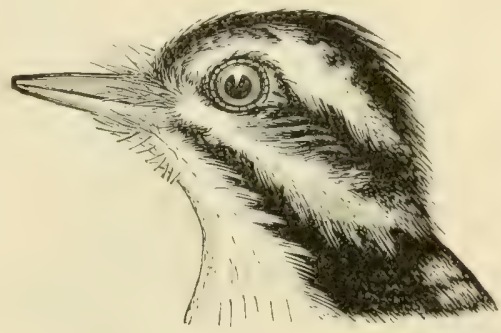

Duwny Woodpecker, natural size.

177-394-(440). Dryobates pubescens Linn. *Downy WOODPECKER.

Very common; throughout the state; abundant at all seasons; "Grand Traverse county" (M. L. Leach); "Mackinac Island" (S. E. White); " common at Iron Mountain" (E. E. Brewster); "Keweenaw Point" (Kneeland); nests in June, more abundantly 
north; hole for nest very smooth, almost polished; eggs four to six, small, clear white. I find, almost always, in the winter and spring, the grub of the large headed borer of the buprestid beetle, Chrysobothrys femorata, in the stomach of this species. This bird feeds largely on the larve and pupe of the coddling moth and our numerous leaf rollers. This and the preceding species are nuch the same, except for size.

Genus PICOIDES Lacel.

$178-100-(143)$. Picoides areticus (Swains.). Arotic 'Threa-toed Woodpecker;

Black-BACKed Three-TOED WOODPeCKer.

Very rare south; abundant near Higgins Lake and north; "not seen at Ann Arbor" (Dr. J. B. Steere); "have seen twenty in one trip through the woods at Howard City and Cadillac" (Dr. M. Gibbs); "found common in pineries by N. A. Eddy $(O$. and O.. Vol. VII, p. 143); "I have no account of it south of Ionia County; "taken not uncom. monly in Grand Traverse and Roscommon Counties" J. C. Nichols); "common in the Gogebic region" (H. Nehrling); embraced in Cabot's Birds of Lake Superior; " not rare on Upper Peninsula" (A. N. Wood in O. and O., Vol. IX, 183t, p. 62); "Keweenaw Point" (Kneeland); "common in North Michigan pineries" (Prof. Ludwig Kumlein); "common in Iron County" (S. E. White); "not rare in Grand Traverse County" (M. L. Leach); common on Saginaw Bay. (N. A. Eddy in O. and O. Vol. IX. p, 5); one in collection of Dr. E. S. Holmes, Grand Rapids, was taken in Kent County, and one in the fine collection of Levi Broas, Belding, was taken in Ionia County. Without doubt this bird breeds in the northern partof this state; "I know of one instance of its breeding in Roscommon County" (Dr. W. C. Brownell); Mr. E. E. Brewster writes me that this birt? is common in winter at Iron Mountain, but he cannot say that it breeds.

179-401-(44). Picoides americanus Brehm. American Three-toen lloodPeCher: Banded-BaCked Thref-Toed Woodpecker.

Fxceedingly rare; "not rare in Northern Peninsula and Gogebic region" (H. Nehr" ing); in Cabot's list of Birds of Lake Superior; "Keweenaw Point" (Kneeland): nserted in Gibls" "Birds of Michigan" on the authority of A. B. Covert; "I know of no record for the state" (Dr. A. K. Fisher).

Genus SPHYRAPICUS BaIRD.

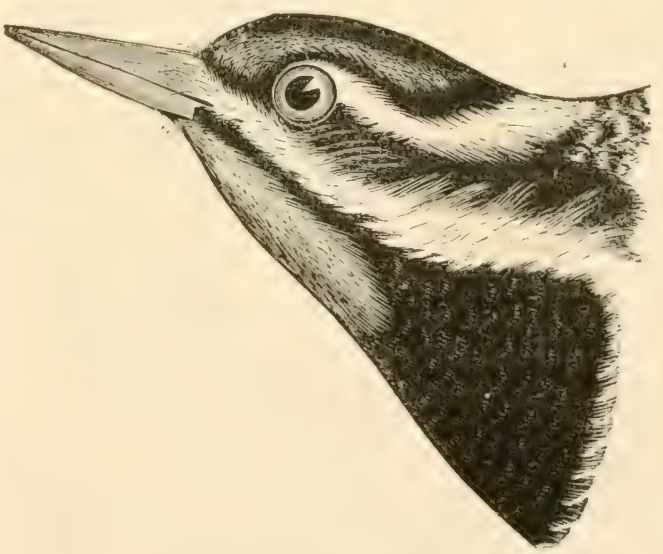

ellow-bellied Woodpecker, natural size. 
1S0-402-(146). Sphyrapiens varius (Limn.). *Yellow-Bellied SAPsucker; TFLLOW-BELLIED WOODPECKER.

Quite abundant in the spring; occasional in summer; found all months from April to October; rarely seen as late as December; breeds in May and June; "often takes three weeks to peck the hole for nest, which is often found in sound ash trees" (Dr. W. C. Brownell); eggs five to seven, white; "the Sapsucker" (Butler's Birds of Indiana); "taps trees more than either the Hairy or Downy Woodpecker according to my observation" (S. E. White); "this is surely the Sapsucker par excellence at Grand Rapids" (E. I. Moseley); "I know it is a Sapsucker as I have seen it at work" (E. B. Boies); "this is the Sapsucker, not only of Indiana but everywhere" (A. W. Butler); the old ornithologists always refer to the Downy and Hairy Woodpeckers as the Sapsuckers, and $I$ and others believe that we have seen them sucking the sap from evergreens here on the college campus. The evidence seems overwhelming that this species is the one that makes the regular holes in pine, orchard and especially maple trees, thus tapping them and coming again for the sap. (See Auk, Vol. 8, p. 256.) Mr. E. E. Brewster writes that this is common at Iron Mountain, where he has shot it as it was taking maple sap. He says that the feathers were all sticky from the sugar on them.

GEXUS CEOPHL(WUS Cab.

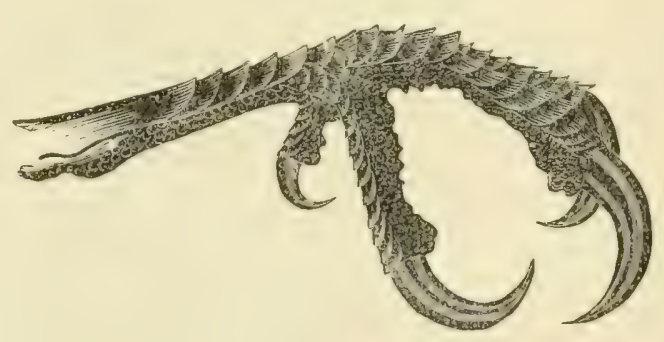

Pileated Woodjecker, natural size.

181 -405-(4:32). Ceophliaus pileatus Linn. *Pileated Woodpecker; Buack Woonpecker; Log Cock; Wooncock (Michigan and Indiana).

Once common throughout the state; found at all seasons; now very rare; one seen near college in summer of 1892; "extinct at Ann Arbor" (J. B. Steere); "not seen in Monroe County since 1887, though once common" (Jerome Trombley); "rare in Kent County" (S. E. White); "Grand Traverse County" (M. L. Leach); "Mackinae Island" (S. E. White); "Keweenaw Point" (Kneeland); "not uncommon at Iron Mountain" (E. E. Brewster); "Upper Peninsula where it probably breeds" (A. H. Boies); still common north, especially in the Northern Peninsula; confined to thick forests; our largest Woodpecker; breeds; "L. E. Reed found a nest with eggs in May, in Van Buren Co." (Dr. M. Gibbs); eggs three to six; noise from pecking heard for long distances. Until within a few years this bird was common in the forests about the college, where I have taken several. 
Genus MELinerpes Swats.

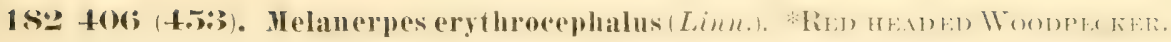

Exceedingly abundant; summer resident; A pril, rarely March, to Sept.; occasional in winter; "often found apparently lifeless in winter, but recovers with warmth" (Dr. W. C. Brownell); throughout the state; "Mackinac Island" (S. E. White); "common at Iron Mountain" (E. E. Brewster); "Keweenaw Point" (Kneeland); breeds abunclantly; nests as usual; eggs five to six; often destroys much fruit, especially cherries; eats grain, especially corn; yet is our friend. Forbes found (Michigan Hort. Soc. Report, 1881, p. 204) that 32 per cent of the food of these birds, which he examined, consisted of canker worms. "I have seen this bird destroy the eggrs of the Bluebird and Phoebe" (S. E. White).

18:3-40!-(450). Melanerpes carolinus (Linn.). *RED-BeLtTED WoodPECKER.

Common, though rare, except in wooded fields: Southern Peninsula; found at all seasons; common from May to August; breeds; nests in May, in holes, often twenty inches deep, usually in rotten wood; eggs four to six, glossy white. See O. and O., Vol. XVI, p. 48.

Genus COLAPTES Sway.

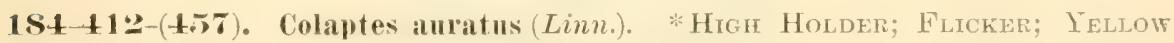
Hammer; Golden-winged Woodpecker.

Formerly very abundant on the college campus, now less common; throughout the state; April to Sept.; occasional at all seasons; reported from Benzie and Presque Isle Counties and Thunder Bay; "very common in Grand Traverse County" (M. L. Leach); "Mackinac Island" (S. E. White); "Keweenaw Point" (Kneeland); " thirty miles north of Mackinaw" (A. H. Wood, O. and O., Vol. IX, p. 62); "common at Iron Mountain" (E. E. Brewster); breeds abundantly; eggs glossy white, five to ten; if eggs are removed daily this bird will often lay as many as thirty, which we have proved at this place; J. B. Purdy in like way has taken twenty-seven from a nest; "feeds abundantly on ants, which it takes from the ground" (E. L. Moseley); "nests in holes, often of apple trees, four to six feet from the ground" (Dr. J. B. Steere); Geo. D. Sones says that this bird is often shot for the table.

\section{Order MaCrochires. Goatsuchers. Sinifts, etc.}

Very valuable insectirorous birds.

\section{Suborder CAPRIMULGI. Goatsuciers, etc. \\ FAmily CAPRIMULGIDE. Gontsuckers, etc.}

Feed wholly on insects; all beneficial.

GeNus ANTROSTOMUS GOULD.

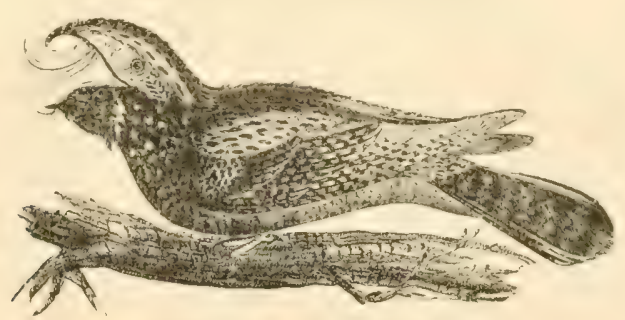

Whip-poor-will, reducerl. 


\section{8.-417-(397). Introstomus vociferus (Wils.). *WhIP-POOR-WILL.}

Common; throughout the Lower Penincula; A pril to Sept.; E. E. Brewster reports it common at Iron Mountain; "Keweenaw Point" (Kneeland); "common at 'Traverse City, where it breeds" (L. W. Watkins); reported from Benzie and Presque Isle Counties and from Mackinac Island: breeds; nests in June, on the ground, in slight hollows or on leaves; eggs two, grayish white, spotted with varying shades of lilac; it is well known by its note at night, which gives it its common name; this note is heard at all hours of the night and at long distances.

Genus CHORIDELES Swats.

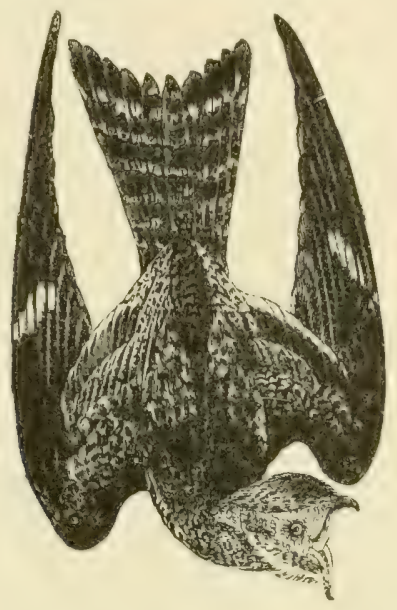

Night Hawk, reduced.

186-420-(399). Chorleiles virginianus (Gmel.). Nighthawk; Goatsucken; Buld Bat.

Very common; throughout the state; seen flying towards nightfall; May to Sept.; "common at Traverse City" (W. L. Watkins); "Mackinac Island" (S. E. White); "Keweenaw Point" (Kneeland); " common at Iron Mountain" (E. E. Brewster); breeds; nests as does the last species, except it nests in open fields, and of ten on houses in eities; "breeds at Traverse City" (L. W. Watkins); eggs two, dirty white specked with varying shades of brown and drab; often confounded with the Whip-poor-wili, but has longer wings, with snowy white spots beneath, and lacks the coarse hair about the bill. Dr. Atkins reports seeing a flock with thousands of birds in August, 1868. The bird has the strange habit of darting down, when it makes a booming sound, which doubtless gave rise to one of its common names; "this bird perches lengthwise of the limb" ( $J$. W. Simmons); Dr. J. B. Steere writes me that this highflier is often seen in cities and often commences flying early in the afternoon. He further adds that it nests on the flat roofs in the city of Detroit. Mr.J. B. Purdy writes me that this and the preceding species are becoming less abundant at Plymouth. "In the spring of 1889, many of these birds perished from starvation in Kent county. The insects for some reason were rery scarce" (S. E. White). 


\section{Suborder CYPSELI. Swifts.}

Family Michopodide. Swifts.

These birds are wholly insectivorous.

\section{Subamir CHATURINA. SPINe-tailed Swifts.}

GENUS CHATURA STEPH.

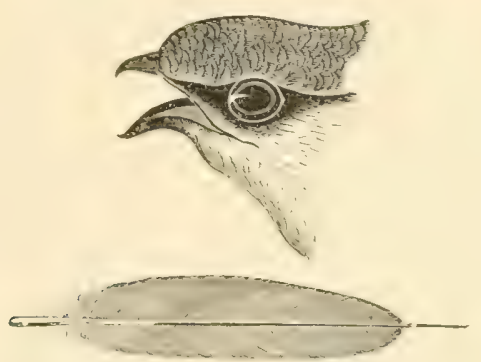

Head and mucronate tail-feather of Chimney Swift, reduced.

187 12:3-(105). Chutura pelagica (Linn.). *hunney Swift; Chuney Swaldow.

Very common; throughout the state; May to Sept.; "common at Traveree City"

(M. I. Leach); I have reports that it is common at Escanaba and Bois Blane Island; "Mackinac Island" (S. E. White); "common at Iron Mountain" (E. E. Brewster); breeds; two or three brooded; "usually single brooded in Ohio and Indiana"(A.W. Butler); nests in chimneys, rarely in hollow trees or barns, occasionally in nests of barn swallows which are first repaired, one case reported; nests made of twigs glued with a secretion formed by the bird; eggs four to six, white; feeds wholly on incects; migrates in fall, often leaving, it is reported, young birds in the nest. These birds are often considered a nuisance in houses having large chimneys.

\section{Suborder Trochili. Hummingbirds.}

\section{Family TROCHILID E. HumangBiRds.}

Wholly American; chiefly from Central and South America; about five hundred species; food, insects and nectar from flowers; beautiful and valuable; Dr. M. Gibbs thinks that the food is almost wholly nectar, but I have positive proof that they are also insectivorous. 
Genus TROCHILUS LinN.

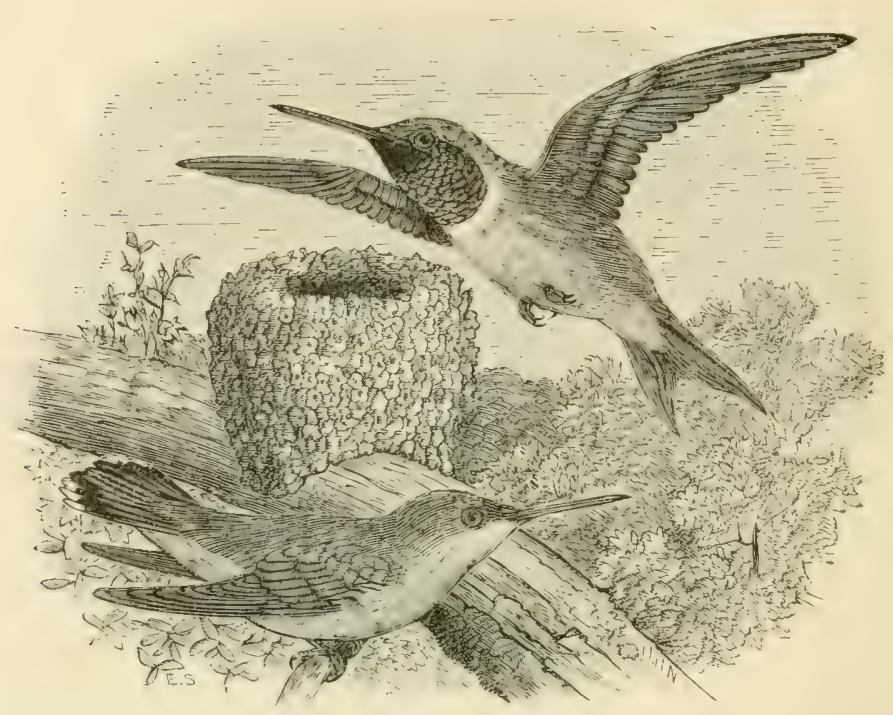

Ruby-throated Humming Bird, male and female and nest, slightly reduced.

1S8-428-(40!). Trochilus colubris Linn. *Rubr-throated Hummingard.

Abundant; throughout the state; common at 'Traverse City and Harbor Springs; E. E. Brewster reports it common at Iron Mountain and S. E. White at Mackinac Island; I have it reported from Benzie county, Escanaba and Bois Blane Island; May to Sept.; breeds; beautiful nests in June on top of a branch and concealed by its beautiful cover of lichens; "Mr. Richard Westnedge, at Kalamazoo, has found many nests, and says that these birds often build in straggling colonies" (Dr. M. Gibbs); eggs two, white; "of six dissections, five of the stomachs exhibited many small insects" (S. E. White). Mr. J. B. Purdy has taken the nest and in six days another was built on the same apple tree by the same bird and had eggs in it. 


\title{
Order Passeres. Perching Birds.
}

Birds with weak feet, usually slight bills, mostly singers.

\section{Stborder Clamatores. Songless Perching Birds.}

\author{
FAMily TYRANNIDE. Flycatchers.
}

Pre-eminent insect feeders; excellent friends.

Genus TYRanNus Cur.

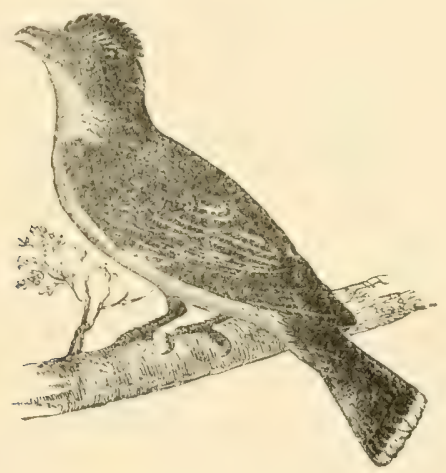

Kingbird, reduced.

189-444-(36S). Tyranums tyraunus (Linn.). *Kingbird; BeE Martin; Tyrant Flycatcher.

Common; throughout the state; May till Sept.; I have reports of this species from Benzie County, Presque Isle, Thunder Bay and Escanaba; "Mackinac Island" (S. E. White); "common at Iron Mountain" (E. E. Brewster); "Keweenaw Point" (Kneeland); breeds; nests in June in orchard trees, etc.; eggs three to five, cream colored, irregularly spotted with brown; kills bees, both workers and drones; does more good than harm as it kills myriads of noxious insects and usually few bees; Mr. L. W. Watkins tells me that this bird breeds at Traverse City. Prof. S. A. Forbes found (report of Mich. Hort. Soc., 1881, p. 204) that forty-two per cent of the food of several examined consisted of insects. 
GeNUS MYIARCHUS CAB.

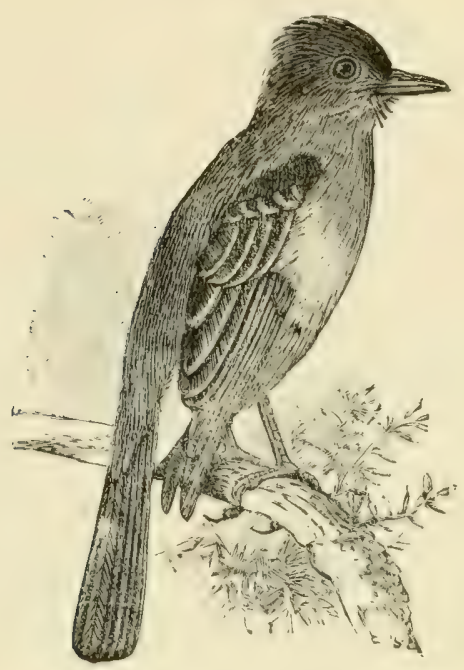

Great Crested Flycatcher, reduced.

190-452-(37:3). Myiarchus crinitus (Linn.). *Crested Flycatcher; Great Crested Fuycatcher.

Common; througout the state; May to Sept.; "Mackinac Island" (S. E. White); rather retiring in its habits; breeds; nests in holes in fence rails, usually in hollows of trees, or old Woodpecker holes; nests often contain cast skins of snakes as a portion of the fabric, as often noticed in our state; eggs four to six, yellowish white, scratched with purple.

GeNUS SAYORNIS Bonap.

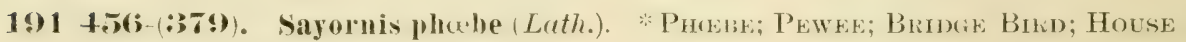
Pewee: Pewit Flycatcher.

Very common; probably throughout the entire state; "Mackinac Island" (S. E. White); "Iron Mountain" (E. E. Brewster); "Keweenaw Point" (Kneeland); breeds very abundantly; nests in May, under bridges or porches, in out houses, etc.; eggs five to seven, pure white occasionally with brown spots at large end; one of our best known and most familiar birds; its plaintive note is known to all.

\section{Genus CONTOPUS Cab,}

192-459-(380). Contopus borealis (Swain.). Olive-Sided Fityoatcher.

Rather rare; throughout the Southern Peninsula; April to Aug.; "rare in Kalamazoo County" (Dr. M. Gibbs); taken by Dr. M. Gibbs in Ottawa County, May 21, 1879 (Bull. Nuttall Ornithological Club, Vol. IX, p. 186); "very common in many northern counties" (C. J. Davis); "abundant at Mackinac Island" (S. E. White); Mr. A. Durfee found a nest in Wayne County in 1859; nests in June, in trees; eggs three to five, as in next species except larger. 


\section{9):-461-(3S*2). Contopus virens (Limn.). *Wond PEWEE,}

Common; general in the state: May to Oct; usually in groves, but not rare about our houses; "Mackinac Island" (S. E. White); "Keweenaw Point" (Kneeland); E. E. Brewster reports it common at Iron Mountain; embraced in Cabot's Birds of Lake Superior; breeds; "breeds abundantly at Traverse City" (L. W. Watkins); nests in June, though occasionally as late as July or even August, in orchards, usually on horizontal limbs, the nests often beautifully covered with lichens, very rare about houses, one reported on ledge under the cornice of a house etc.; eggs three, creamy white, with spots of brown at the large end; very beneficial. The novice is likely to confuse this bird with the Phoebe; its note is very sweet and beautiful.

GiENUS EMPIDONAX CAB.

194-46:3-(3SS). Empidonax flaviventris Baird. *YELLOW-BELLIED FLYCATCHER.

Not rare; "not rare during spring migration, one taken in Kalamazoo County" (Dr. MI. Gibbs); "Iron Mountain" (E. E. Brewster); Mr. S. E. White reports this species qu ite common at Mackinac Island at time of fall migration; said to breed in the northern part of the state; eggs usually four.

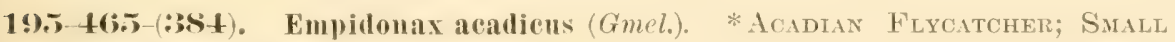
Grefin-Crested Flycatcher.

Abundant; usually in thick woods; May to Aug.; "in southern part of the state" (Prof. J. A. Allen); "common at Greenville" (Prof. Jas. Satterlee); "Mackinac Island" (\$. E. White); breeds; nests in June at the end of limbs of trees or bushes; "nests along creeks in eldex bushes, and is very shy" (Dr. W. C. Brownell); eggs two to four, usually three, color as in Wood Pewee. This bird is often mistaken for the next two species.

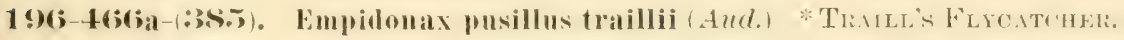

Common; "common in some localities in Monroe County" (Jerome Trombley); "Mackinac Island" (S. E. White); breeds; "have found twenty-five or thirty nests for sereral consecutive years in Dundee township" (Jerome Trombley); nests in June, usually in willows and alder bushes, beside streams; "nests in thick woods at end of. beech or maple limbs" (Dr. W. C. Brownell); have not Messrs. Trombley and Brownell mistaken the Acadian for Traill's Flycatcher in the above notes? Such misidentifications are common in studying these birds; eggs four, indistinguishable from those of the Acadian Flycatcher.

\section{7-467-(\$357). Empidonax minimus Baird. * Least Fuycatcher.}

Common throughout the state; April till Sept.; "common in Hillsdale county " (A. H. Boies); "and in Monroe County" (Jerome Trombley); "Mackinac Island" (S. E. W hite); "Iron Mountain" (E. E. Brewster); breeds; often double brooded; nest found in Wayne County by A. Durfee in 1859; nests in May, in trees in woods, occasionally in orchard and other trees, frequently close by the house; eggs four, white or creamy white. We find this species far more common here than either of the two preceding. 


\title{
Suborder OSCINES. SoNg Birds.
}

\author{
Family ALAUDID五. Larks.
}

Insect feeders; sing on the wing.

GeNus OTOCORIS Bonap.

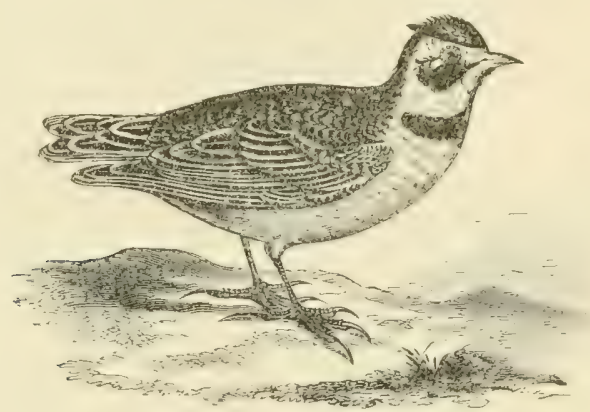

Horned Lark, much reduced.

198 174-(82). Otocoris alpestris (Limn.). *Horned Lark; Shore Lari.

Rather rare; irregular fall and spring visitor; "late fall in Kent County" (S. E. White); not very rare in winter; breeds in Greenland and Labrador; often seen in barn-

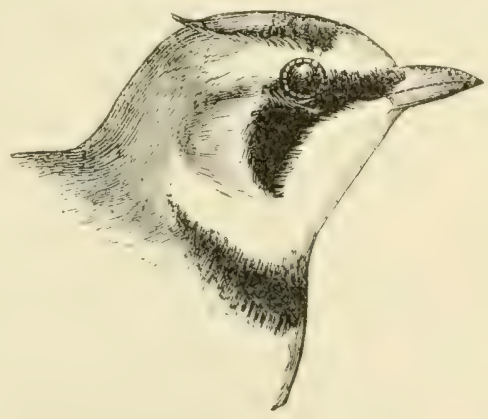

Horned Lark, natural size.

yards, feeding on seeds, etc.; this bird is often confused with the following subspecies, which is more common in our state. From what Dr.J. B. Steere writes me, I judge that this is the more common at Ann Arbor.

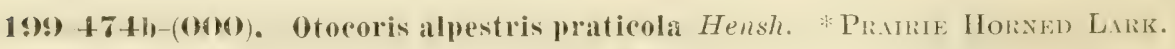

Summer resident; Jonathan Dwight, Jr., found them at Ann Arbor and Cadillac where they were breeding (Auk, Vol. VIII, p. 138); "very common at Iron Mountain" (E. E. Brewster); breeds; nests on the ground; in April or earlier; "breeds abundantly in Kent county" (S. E. White); J. B. Purdy, of Plymouth, has found eggs in nest in February; nest often surrounded by snow; may be double or triple brooded; eggs four or five, gray specked with brown; food insects and seeds. Mr. L. W. Watkins took one on eggs March 20,1889, the nest was surrounded by snow. This subspecies and the ${ }^{\circ}$ 
preceding overlap each other in this region during winter, and so are very generally confused throughout the state. The species and sub-species are thought generally to be one and the same bird.

\section{Fhimly CORVIDE. Crows, Magpies fic.}

Food habits rather omnirorous.

\section{Subfaily GarRuline. Magpies and Tays.}

Genus CYANOCITTA STRICKI.

\section{0-477-(34!)). Cyanocitta cristata (Linn.). * BLUE JAY.}

Very abundant; throughout the state; common in all seasons; reported from Presque Isle and Bois Blane Island; "common at Grand Traverse County" (M. L. Leach); "abundant at Mackinac Island" (S. E. White): "not common on Keweenaw Point" (Kneeland); "common in Upper Peninsula" (A. H. Boies); "common at Iron Mountain" (E. E. Brewster); breeds; nests in thick foliage, especially evergreens, very rarely in barns, one case noted; eggs four to five, "six" (E. Clute and D. Reynolds), light green or drab, spotted with light brown; feeds on acorns, hazel nuts, insects. fruits, young birds and birds eggs etc.; often kills birds, especially nestlings; Dr. G. W. Torping, of DeWitt, has repeatedly seen these birds take young Sparrows and Gold Finches from the nests and then eat them; "killed a young Baltimore Oriole and took its brain, leaving the rest of the careass" (I. W. Watkins); an English Sparrow received similar treatment from this bird. on the college campus in the spring of 1893; a rather doubtful friend; note harsb; too handsome to kill. Prof. J. A. Allen informs me that he has taken a great number of the eggs of the tent caterpillar, Clisiocampa americuna. from their stomachs in winter in Massachusetts.

\section{Genus PICA Cuv.}

\section{¿01-475-(347). Piea pica hudsoniea (Sab.). American Magrie.}

Said to wander to Michigan (see Youth's Companion, December, 1892); "I have seen a few specimens taken at Eagle Rirer" (Kneeland); Butler's Birds of Indiana, p. 113; Ridgway's Manual of North American Birds, p. 352, and Jordan's Manual of Vertebrates; "very doubtful" (Dr. A. K. Fisher).

Genus PERISOREUS Bonap.

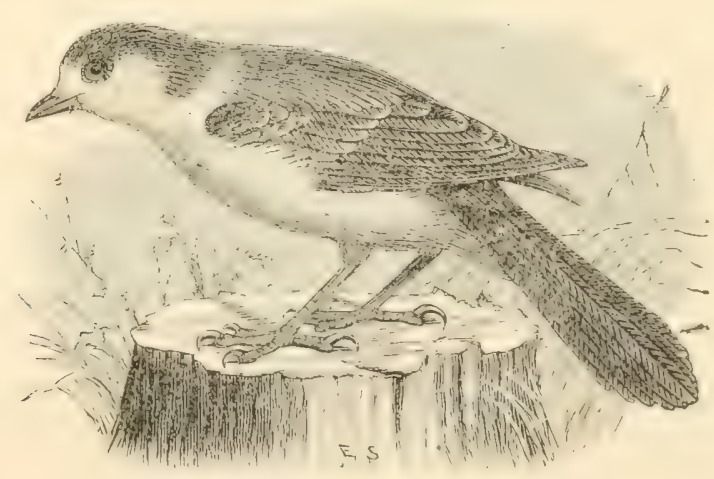

('anada Jay, reduced. 


\section{0-18t-(359)). Perisoreus cautdeusis (Linn.). *CANADA JAY.}

Common from the middle of the Southern Peninsula northward; never seen in the southern part of the state; seen on our college grounds in the winter of 1893; "first seen May 17, 1876" (Dr. H. A. Atkins); it seems strange that it should oceur at Locke as late as May: "common north about the logging camps" (R. H. Wolcott); A. H. Boies took a pair at Sault Ste. Marie, Oct. 20, 1892; "very abundant at Iron County, Upper Peninsula, also in the Gogebic region" (H. Nehrling); "a Hock of eight were seen at Mackinac Island" (S. E. White); common in some sections of the Northern Peninsula" (Prof. Ludwig Kumlein); "common on Keweenaw Point in winter and a pest to the trappers as it steals the poisoned bait" (Kneeland); "abundant in Grand "Traverse County" (M. L. Leach); taker by J. E. Nichols in the autumn of 1881 and 1883 in Roscommon, Kalkaska and Missaukee Counties; "common in Crawforct County, about lumber camps" (Dudley E. Waters); Dr. Atkins reports taking this bird at Locke, May 17, 1876; "common in spring and fall, but not in summer in Iron County" (E. E. Brewster); this bird is reported to be troublesome about lumber camps, carrying off meat, ete. It doubtless breeds in the northern part of the state.

\section{Subamily CORVINA. Crows and Ravens.}

Genos colrves Lins.

\section{$20: 3$ 486-(:3:3). Corvus corax sinuatus (Waql.). * AMERICAN RAven.}

Formerly common; not rare now north; we no longer see it about Lansing; " rare but still seen at Ann Arbor" (Dr. J. B. Steere); "common at Grayling, where it nests" (Prof. L. H. Colburn); "very common on Kewenaw Point in the winter to the exclusion of the crow" (Kneeland); "throughout the Upper Peninsula" (A. H. Boies); "common but very shy in Iron County, two taken in Kent County April 8, 1888" (S. E. White): "common at Iron Mountain, Dickinson County" (E. E. Brewster); "see them occasionally in Shiawassee County, Hying very high" (Dr. W. C. Brownell); "wholly gone from Greenville, Montcalm County, where it was common thirty years acro" (Prof. Jas. Satterlee); "common in Monroe County, prior to 1860 , before the advent of the crow" (Jerome Trombley); this bird seems to be replaced south by the crow; feeds on carrion. acorns, etc.; Dr. Gibbs writes me that he has known of its breeding in Van Buren County, and thinks it must lay eggs as early as February. Nest and eggs much as in the next species.

\section{1-18S-(340). Corvis americanus Aud. *American Crow, Common Crow.}

Very common; throughout the state; gregarious; seen at all seasons of the year: more rare in winter; "seen first in Monroe County in 18 30, now very common, but not in winter" (Jerome Trombley); "Grand Traverse County" (M. L. Leach); " not rare "it Mackinac Island" (S. E. White); common on Keweenaw Point and in the Ontonagon District" (Kneeland); "general in Upper Peninsula" (А. H. Boies); "common in summer at Iron Mountain" (E. E. Brewster); breeds; nests in large, coarse nests in trees: egrgs four to six, Dr. W. C. Brownell has a set of seven, green, blotched and sprinkleil with dusky brown; eats insects, frogs, carrion, acorns, eggs of birds and poultry, "especially young chickens" (O, and O., Vol. XVI, 1891, p. 61.); probably our friend. 
Family iClétide. Starlings, Blackirdo, Orioles.

Generally insect feeders, a few eat corn, some fruit, on the whole our friends; generally gregarious; eggs usually much speckled, often marked with zigzag or broken lines.

Genus DOLICHONYX \$WAINS.

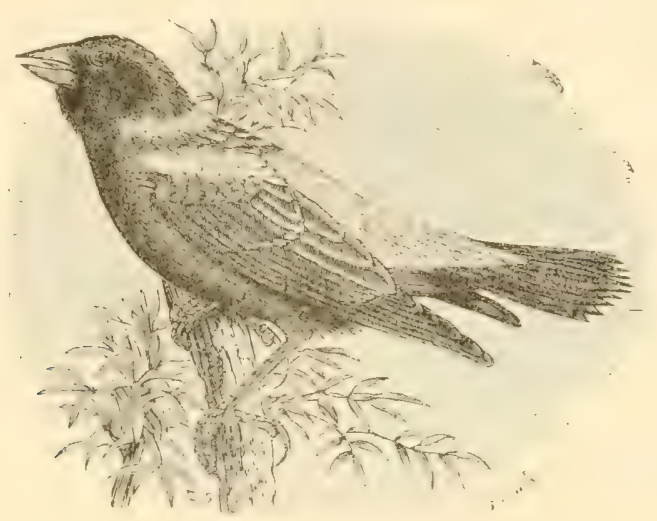

Bobolink, male, reduced.

205-494-(312). Dolichonyx oryzivorus (Linn.). *Bobolink; Skunk Buackbird; Reed Bird; Rice Bird; Bob Lincoln; Ortolan; Butter Bird.

Very common; Southern Michigan; summer; May (one of the latest birds to arrive) to September; male takes the plumage of the female in the fall; beautiful singer at nesting season; not shy; breods; nest.s in June, usually in meadows, on the ground; eggs five, occasionally six to seven, bluish white, marked with dark brown specks; not in Central Michigan until within a fow years; I first noticed it about tho college in 1874; "first in Monroe County in 1872" (Jerome Trombley); Dr. Atkins reports it very common in 1875 but very rare until $187 t$ at Locke; "first seen at Plymouth forty years ago" (J. B. Purdy); Dr. G. W. Topping says that it first appeared at DeWitt in 1881, and was numerous from the first; I have reports of this bird as far north as Benzie County, in the Southern Peninsula, and Mr. E. E. Brewster, of Iron Mountain writes me that it occurs rarely at that place.

GenUs MOLOTHRUS SWAIN.

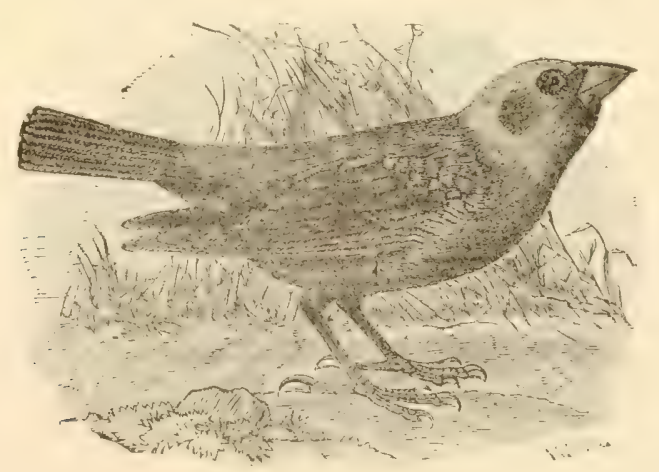

Cowbird, reduced. 
206-495-(313). Molothrus ater (Bodd.). *Cowirin); SAzY Brrd; Cow Buntinc.

Increasingly abundant; throughout the State; March to November; insect feeder;

"Keweenaw Point" (Kneeland); rests on cattle and picks Hies, henee name Cowbird; often in flocks; lays its eggs "extensively" (L. S. Foster) in other birds" nests, especially in nests of Grass Finch, Chipping and Song Sparrows, Orchard Orioles, Thrushes Warblers, King Birds and Pewee; Mr. A. H. Boies thinks that this bird lays only one egg in any one nest (O. and O., Vol. IX, 1884, p. 90); Jerome Trombley has taken these eggs from the nests of thirty other kinds of birds; Prof. James Satterlee has taken eggs in Greenville, Montealm County, from the nests of the Hermit Thrush and the Greencrested Flycatcher; Dr. Gibbs has found its eggs in the nests of the Wood Thrush, Bluebird, eight species of Warblers, Scarlet Tanager, Chewink, Traill's and Acadian Flycatchers, three species of Vireos, and five other species. R. H. Wolcott has found its eggs in the nest of Wilson's Thrush, Blue-gray Gnateatcher, Yellow Warbler, Swamp Sparrow, Song Sparrow, Chipping Sparrow, Rose-breasted Crrosbeak. Indigo Bird, Orchard and Baltimore Orioles, Wood Pewee, and once in that of the Meadow Lark; F. M. Falconer finds the eggs most frequently in the nest of the Yellow Warbler; and in two cases he has found the eggs covered over and a new set deposited; Dr. Atkins reports finding eggs in the nest of the Golden Crowned Thrush, Rose-breasted (irosbeak and Hooded Warbler; in this peculiar habit this bird is like the European Cuckoo "(usually) lays eggs in nests of small birls which have a longer period of ineubation, thus giving its young the tirst chance and 'freezing out' the rightful possessor" (C. J. Davis); S. E. White reports this bird at Mackinac Island but only as a migrant, and E. E. Brewster writes that it is common at Iron Mountain. "A male was seen daily the winter of 1892 at Alma, Michigan, with a flock of English Sparrows." "I have seen eggs walled in in Yellow Bird's nests" (Prof. C. A. Davis). A. H. Boies has given a similar case in $\mathrm{O}$. and $\mathrm{O} ., \mathrm{Vol}$. IX, 1884, p. 128. For interesting article on this species by Dr. M. Gibbs, see O. and O., Vol. XV, 1890, p. 5.

Genus Xanthocephalus Bonap.

\section{7-497-(319). Xanthocephalus xanthocephalus (Bonct).). Yellow-hfadfo} BLACKBTRD.

Very rare; "extreme southwestern part of the State; probably breeds" (Gibbs); "never seen at Ann Arbor" (Dr. J. B. Steere); "very doubtful if it breeds in the State", (A. H. Boies); one taken at Iron Mountain, Northern Peninsula, May 17, 1890, by E. E. Brewster; "common in Northern Wisconsin and presumably in the Northern Peninsula" (Prof. Ludwig Kumlein); "breeds in Lake County Indiana" (Butler's Birds of Indiana).

\section{Gends agelaius Vietll.}

\section{S-49S-(316). Agelaius phonicens (Linn.). *Ren-Wingen Blackbird.}

Exceedingly common; throughout the state; March to September; "Traverse City where it breeds" (L. W. Watkins); "common at Mackinac Island" (S. E. White); "common at Iron Mountain" (E. E. Brewster); "Keweenaw Point" (Kneeland); breeds; two broods; nests in May, in grass clumps or low brush-wood in marshes; nests usually surrounded by water; eggs four to five, rarely six, light blue, streaked and specked with brown or black; food insects and grain, principally corn; often seen in flocks especially in autumn. 
Genus sturnella Fieitl.

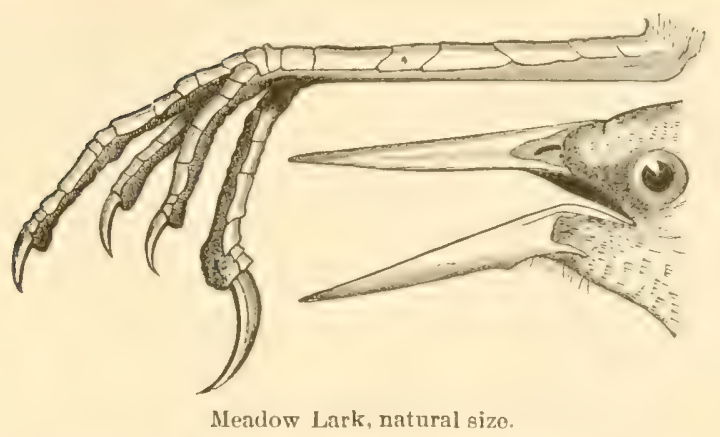

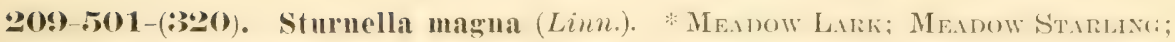
Field Lark.

Exceedingly abundant; throughout the state; March to October; often seen every month in the year; "very rare at Mackinac Island, seen in July, 1889" (S. E. White); "does not occur at Iron Mountain, as I have not seen it or heard its note" (E. E. Brewster); L. W. Watkins has found it breeding at Traverse City; nests in May on the ground; eggs five to seven, white with brown spots, rarely immaculate; "often shot for game" (Geo. D. Sones).

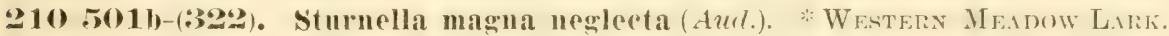

Although this is included in Covert's and Stockivell's lists, I doubt its occurrence in our state. Dr. Gibbs writes me to the same effect. Dr. Atkins states that he saw a flock September 8,1876 . Were not these immature specimens of the preceding species? Prof. J. A. Allen writes me that he thinks Dr. Atkins was mistaken in his identification. Prof. A. W. Butler identified one from Cook County, Illinois, only two counties removed from Michigan.

Genus ICTERUS BRISs.

211-506-(324). Ieterus spurius (Linn.). * Orchard Oreole.

Common summer sojourner; rare about Lansing; "common in Kent County" (S. E. White); "very common at Greenville, Montcalm County" (Prof. James Satterlee); "very common in Cass County, where it breeds in June" (J. W. Simmons); breeds abundantly at Plymouth, and usually lays five eggs" (J. B. Purdy); taken frequently in Ionia County by Mr. Levi Broas; "common in Wayne County where it breeds" (B. W. Swales); "rare but breeds at Ann Arbor" (Dr. J. B. Steere); breeds plentifully in the southern part of the state; Dr. A tkins took a specimen May 25, 1892, at Locke, Ingham County; "nests abundantly at Manchester, often in spruce trees, nests usually pendant, but shorter than in the next species, woven closely to twigs and much concealed " (L. W. Watkins); eggs four to six, smaller than in the next species, and the dashes shorter.

212-507-(326). Ieterus galbula (Linn.). * Baltimore Oriole; HaNG Nest; Fire Bird.

Common; throughout the Lower Peninsula at least; "never seen at Iron Mountain" (E. E. Brewster); "I have never seen it at Mackinac Island" (S. E. White); May, rarely April, to August; "common at Traverse City, where it breeds abundantly" (L. W. Watkins); "common even in the City of Ann Arbor" (Dr. J. B. Steere); breeds; nests "purse-shaped" (L. S. Foster), suspended; "I have a nest constructed wholly of 
horse hair from mane and tail of a horse" (Prof. J. W. Simmons); nests usually at the ends of limbs of tall trees (it often selects elms or the top-most limbs of orchard trees); eggs four to six, pinkish white or bluish white, scratehed with brown; feeds on insects (will even eat the large tomato worm) and fruit; beautiful bird; sweet singer; next to the Scarlet Tanager this is the most showy of our common birds. I have seen these birds eat the young bark lice from linden trees in the spring, and have seen them driven away by the bees and wasps that come for the honey dew.

\section{Genus SCOLECOPHAGUS Swain.}

213-509) (3:31). Seolecophagus carolinus (Mül.). *Rusty Blackird; Rusty Grackle.

Abundant throughout the state; migrant; "only a migrant at Ann Arbor" (Dr. J. B. Steere); observed at Sault Ste. Marie by $\Lambda$. H. Boies; E. E. Brewster has taken it at Iron Mountain; "Mackinac Island" (S. E. White); "Keweenaw Point" (Kneeland); "probably breeds" (Gibbs' Birds of Michigan); may possibly breed in Northern Peninsula.

\section{Genus QUiscillus VIeill.}

214-511d (:337). Quisealus quiseula arneus (Ridgw.). * Bronzen Grackle: Bronzed Crow Brackird; Crow Blackbird; Common Blaokbird.

March to September; exceeding abundant; throughout the state; "of ten in cities" (Geo. D. Sones); often in immense flocks especially in spring and fall; "decreasingly common in Monroe County" (Jereme Trombley); "Mackinac Island" (心. E. White); common at Iron Mountain " (E. E. Brewstor); breels; nests in May and Jure in large coarse nests in swamps, in bushes usually near the ground - R. H. Wolcott has found them in evergreens forty feet from the ground; eggs four to six, rarely seven, light blue to light brown, streaked and specked with hrown and black; feeds on insects, especially white grubs, and pulls up corn and eats corn from the ear; Prof. Jas. Satterlee once found a nest in a hole in an old dead tamarack, and $\mathrm{R}$. H. Wolcott reports the same from Ann Arbor, where the nest was in an old stub standing in the river. Dr. M. Gibbs writes me that he finds such nesting common in new regions where old trees are abundant.

Family fringildid A. Finches, Sparrows, etc.

Feed on seeds and insects; our native species all beneficial. Many species are sylvan, while others frequent the cleared fields.

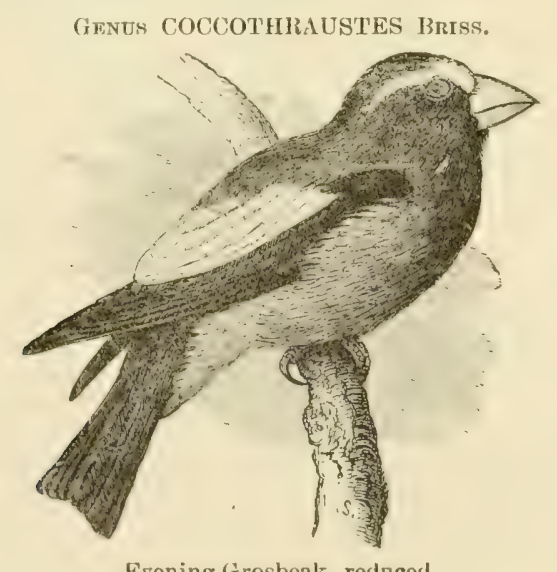

Evening (Grosbeak, reduced. 


\section{5-514-(189). Coccothraustes vespertina (Coop.). Evenivg Grosbenk.}

Winter; rarely seen; oceasionally very common; type specimen described by Cooper was from Sault Ste. Marie; E. E. Brewster reports a large Hock at Iron Mountain in the winter of 1882; Mr. L. H. Colburn sent me one shot from a flock in Van Buren County in 1887; winter of 1889-9J at the college in flocks; "Ann Arbor in 1887 and 1890 " (Dr. J. B. Steere); "very abundant at Alma and Saginaw in vinter of 1889-90" (Prof. C. A. Davis); "several small flocks in Monroe County in winter of 1889-90" (Jerome Trombley); "attracted into houses by feeding, caught and kept in eages for two years, all males and so could not breed" (L. W. Watkins); Dr. M. Gibbs saw this bird in company with the Rose-breasted Grosbeak in Kalamazoo County in late April, 1879 ('The Auk, April, 1892). For very full monograph of this bird see article by Prof. A. W. Butler in The Auk, Vol. IX, July, 1892, pp. 238-247, also "Further Notes on the Evening Grosbeak," The Auk. April, 1893, pp. 155-157. This article refers largely to observations on this species in Michigan. He shows that this bird was general in Michigan in the winter of 1890 from January to May.

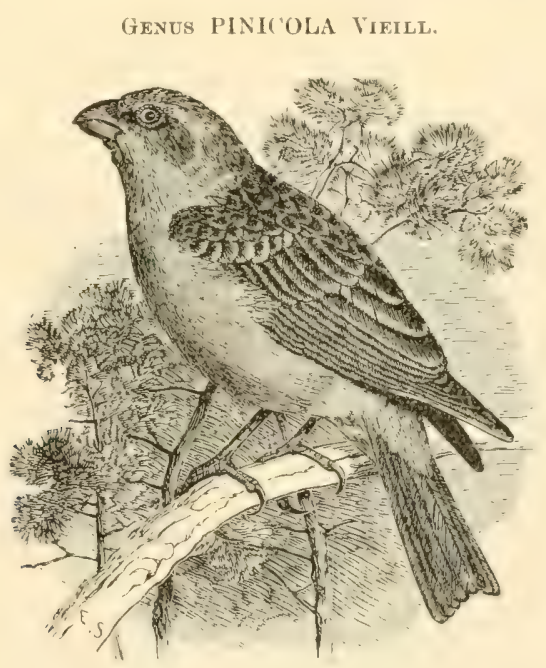

Pine Grosbeak, reduced.

216-515-(19)). Pinicola enucleator (Limn.). *PINe Grosbean.

Occasional in winter; often in large flocks; "in flocks of thousands in Jackson County in 1881, where they were very tame" (Dr H. A. Atkins); we have one in our museum from Ionia County, taken in January; "common in Bay County from November, 1883, to April. 1884" (N. A. Eddy, in O. and O.. Vol. IX, p. 41); "occasionally a straggler from the north in Kalamazos County, in winter " (Dr. M. Gibbs); " Kewee naw Point" (Kneeland); "not uncommon at Iron Mountain and north, where I think it breeds" (E. E. Brewster); I was surprise I to find but one in the large collection of Mr. Leri Broas, made in the northern part of Ionia County. 
GeNUS CARPODACUS KAUP.

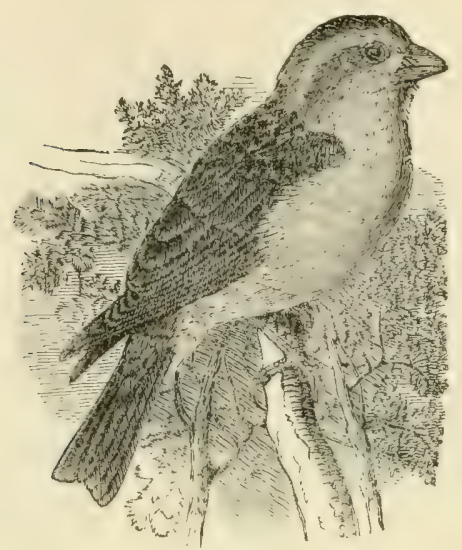

Purple Finch, male, reduced.

217-517-(194). Carpodacus perpureus (Gmel.). *Puiple Finch.

Rather common; throughout the state; flocks; usually a migrant; occasional in summer; "only a migrant at Ann Arbor" (Dr. J. B. Steere); F. L. Washburn reported a flock at Ann Arbor May 24 (The Auk, Vol. VI, p. 279); "not known in Kalamazoo in summer" (Dr. M. Gibbs); "Hillsdale and Lenawee Counties" (A. H. Boies); "does not breed in Plymouth" (J. B. Purdy); "rare in Wayne County" (B. W. Swales); "breeds abundantly at Mackinac Island" (S. E. White); "Keweenaw Point" (Kneeland); "rare at Iron Mountain" (E. E. Brewster); occasionally breeds; nests in May, in trees, often close about houces; Mr. Howard B. Baker knew it to nest in an evergreen close by his father's house in Lansing; eggs four to five, very light dull green, speckled with dark: spots; sweet singer.

Gends LOXIA Linn.

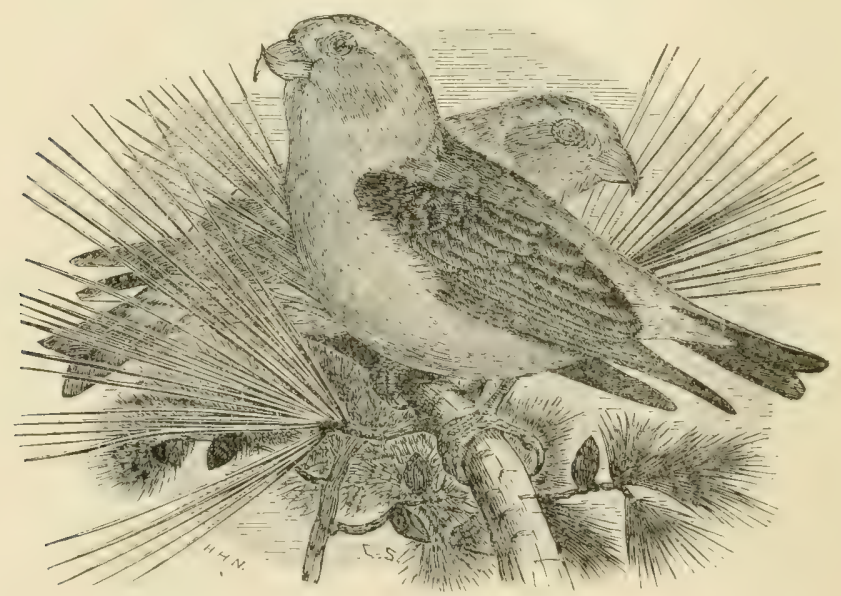

Rel Crossbill, male and female, reduced. 


\section{5-521-(19!)). Loxia curvirostra miner (Brehm), *Avertosic Crossbilz; Red}

Crossbiti.

Often very common; throughout the Southern Peninsula at least; winter; Nov, to May; occasional in summer; "irregular at Ann Arbor" (Dr. J. B. Steere); "only in winter and spring at Plymouth" (J. B. Purdy); "not common in Lenawee and Hillsdale Counties" (A. H. Boies); "common in Grand Traverse County" (MI. L. Leach); "very common at Iron Mountain, think it breeds" (E. E. Brewster); F. MI. Falconer reports it from Hillsdale in March and April, where a nest was found by Mr. Dempel March 24. 1892, in a spruce, twenty feet from the ground, and one erg taken; "summer resident at Mackinac Island, where it breeds " (S. E. White); "Keweenaw Point" (Kneeland); breeds north; "I think it nests in March or earlier" (Dr. M. Gibbs); "usually February and March" (Davie, p. 289); nests in trees; eggs three to five. greenish gray specked with brown; Dr. Atkins reports taking the nest of this bird at Locke; he also states that he has known it to peck holes in apples to secure the seeds.

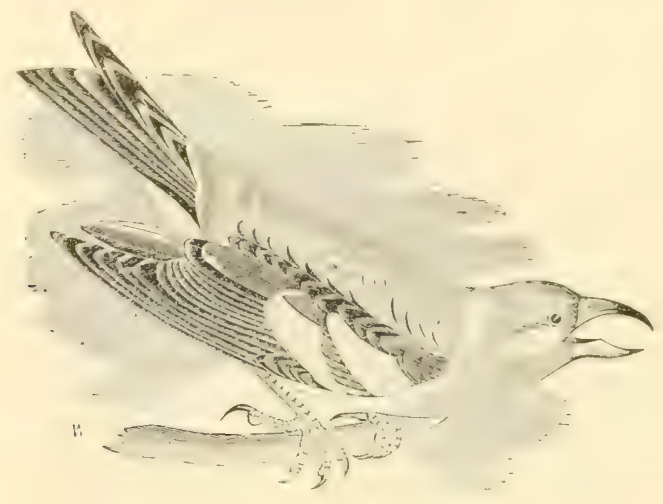

White-winged Crosebill, reduced.

219-523-(198). Loxia lencoptera Gmel. *White-Winged Crossiril.

Often common; throughout the Lower Peninsula at least; south only in winter; Dr. Atkins reports killing one at Locke. August 9, 1875; "common in Kent County in winter" (S. E. White); "uncertain winter visitor at Ann Arbor" (Dr. J. B. Steere); "one pair killed at Plymouth" (J. B. Purdy); Samuel Spicer, of Genesee County, reports finding one nesting Sept. 28, 1888 (O. and O., p. 43, 1889); "Keweenaw Point" (Kneeland); S. E. White finds it in July and August at Mackinac Isiand. where it probably breeds; "breeds in Northern Wisconsin and Northern Peninsula of Michigan" (Ludwig Kumlein); this bird is a rather fine singer.

GeNus ACANTHIS BeCH.

220-52S-(207). Acanthis linaria (Limn.). *Redrolt; Common or Lesser RedPOLL; Redpoli Linnet.

Occasional winter resident; November to March or April; Hocks; "irregularly abundant at Ann Arbor, there were thousands in 18s8, very rare since" (Dr. J. B. Steere); "often common in Lenawce County" (A. H. Boies); "common in winter at Iron Mountain" (E. E. Brewster); "Keweenaw Point" (Kneeland); I have it reported from Thunder Bay Island; very sweet singer; feeds mostly on buds and seeds, especially seeds of the arbor vitae. 


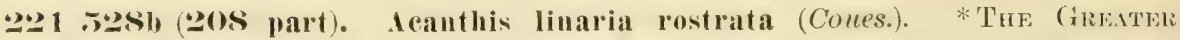

REDPOLL.

"Occasional straggler, taken in flocks of last species" (Dr. M. Gibbs). Dr. Gibbs" specimen taken at Kalamazoo was identified by Mr. Robt. Ridgway. These birds are often giren as Acanthis linaria holbollii, which is without doubt an error (see Butler's Birds of Indiana, p. 69).

\section{GENUS SPINUS KoCH.}

220-509-(21:3). Spiuts tristis (Limn.). *American Goldfinch; Yellow Bird; T'histue Bird.

Very common; throughout the Lower Peninsula; every month in the year; more common in summer; yellow in summer, darker in autumn and winter; occasional in midwinter; in fall and winter feeds on seeds; gregarious at all seasons except while breeding; but the largest flocks occur in winter" and July" (E. L. Moseley); "Grand Traverse County" (M. L. Leach); "common at Iron Mountain" (E. E. Brewster); "Mackinac Island" (S. E. White); "not seen in Upper Peninsula" (A. H. Boies); breeds; nests in July and August; "never before July" (R. H. Wolcott); "usually as late as July and often in August and September" (Prof. Ludwig Kumlein); we have found nests with five eggs Sept. 10, one reported found Sept. 28, 1888 (O and O., Vol. XIV. 1889); nests in orchard trees and occasionally in low shrubs; eggs three to six, bluish white; Dr. H. A. A tkins and Mr. L. W. Watkins have both reared the young by putting the eggs under a common canary.

22:3-5:3:3-(212). Spinus piuns (Wils.). Pine Sishin; Pine Linnet; Pine Finch.

Rather rare; throughout the state; "rare at Ann Arbor" (Dr. J. B. Steere); "common in Wayne" (B. W. Swales); "transient in Monroe County, often in flocks in spring even to April and May" (Jerome Trombley); "very abundant in the pine forests north and often seen in southern counties" (Dr. M. Gibbs); winter; "killed from flocks at Iron Mountain, May 23, 1892" (E. E. Brewster); "Keweenaw Point" (Kneeland); " common in winter in Kent County, and a summer resident on Mackinac Island" (S. E. White); Dr. Atkins reports taking it in February and twice in May; "breeds in Michigan" (Davie's Nests and Eggs of North American Birds, p. 293).

GeNus PLECTROPHENAX STET.

294-5:34-(219). Plectrophenax nivalis (Lina.). * Snowflake; Snow Bunting; White SNow Bird.

Common, though fitful, not seen every winter; throughout the entire State; November to March; often migrant; "Lenawee and Hillsdale Counties, and common in the Upper Peninsula," (A. H. Boies); "Keweenaw Point" (Kneeland) "immense Hocks at Morrice, Shiawassee County, Feb., 1893 " (Dr. W. C. Brownell); "common at Iron Mountain from late October till snow flies " (E. E. Brewster); saw a flock of hundreds near Owosso, January, 1892, they would follow the manure wagon to gather seeds " (Bert B. Cook); "present in Kent county from October 28, 1890 to March 7, 1891 " (S. E. White); reported from Mackinac Island; "usually does not come till snow covers the ground" (Prof. C. A. Davis). 
Gexus Calcarius Bechst.

2205-5:36-(200). Calearins lapponiens (Limn.). Lapland Lonespur.

Rare; migrant; spring and autumn; often winters in Southern Michigan; "one pair killed at Plymouth" (J. B. Purdy); "generally a transient visitor from the north, occasionally spends the winter south of $43^{\circ}$ north latitude" (Gibbs" Birds of Michigan); October to April; reported from Wayne County and Mackinac Island; "Keweenaw Point" (Kneeland); it is said to be a common spring migrant in Northern Indiana (Butler's Birds of Indiana).

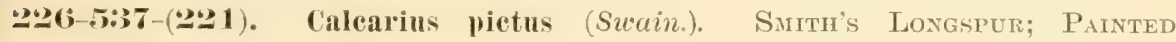

Loxispler.

Reported common on the southern shore of Lake Michigan (Butler's Birds of Indiana); Dr. M. Gibbs thinks this may be found in Michigan; migrant; in flocks.

GENUS POQR FTEX BAIRD.

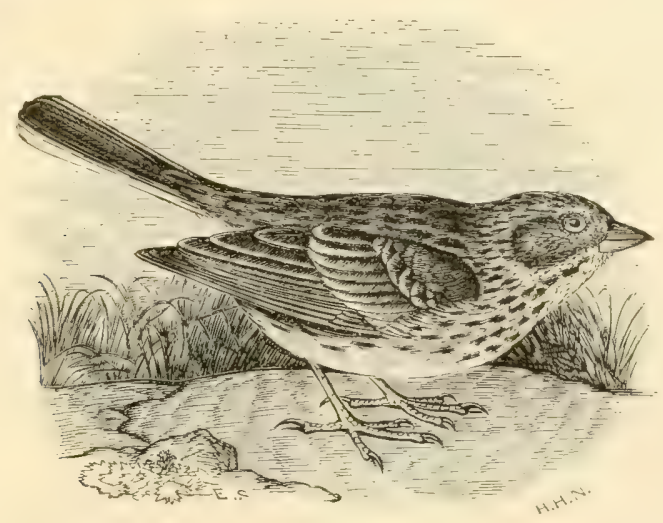

Grass Finch, reduced.

227-540-(2:32). Poocres gramineus (Gmel.). *Vesper Sparrow; Bay-winged Bunting; Grass Finch; Ground Bird.

One of our most common finches; throughout the State; A pril to October; " Mackinac Island" (S. E. White); "common at Iron Mountain" (E. W. Brewster); "Keweenaw Point" (Kneeland); "next to song sparrow our most common finch" (J. Trombley); its pretty evening song - resper song-gives it one of its common names; breeds; two or three broods a year; nests in May, June or July. on the ground, in pasture. meadow, and by the roadside; eggs four, gray, specked with dull brown; birds not shy; like all our native sparrows, insectivorous and valuable. 
Genus PaSsER Briss.

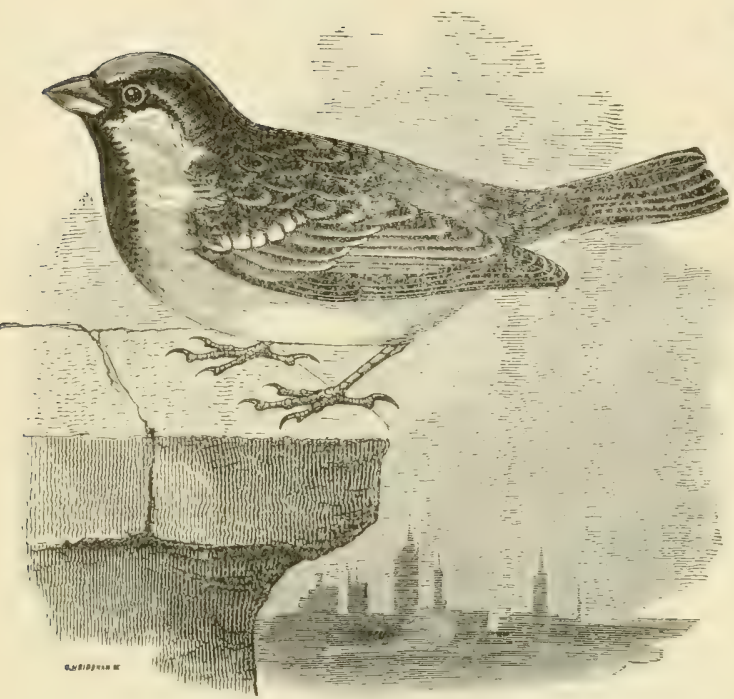

English Sparrow, male.

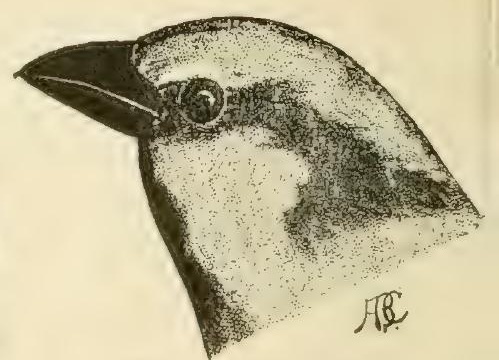

Male, nat. size original.

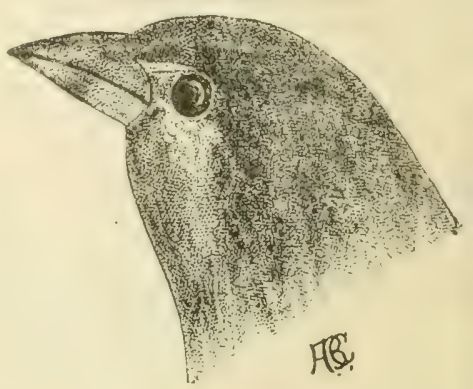

Female, nat. size original.

228-000-(192). Passer domesticus (Linn.). *Exglish Sparrow; European

Sparrow; House Sparrow; Parastte; Tramp; Hoodlum; Gammon; Philip Sparrow.

Imported species; introduced into New York in 1850; introduced into Michigun in 1879; "first seen at Hubbardston, Ionia County, 1885" (Prof. C. F. Wheeler); very common; already throughout the Lower Peninsula; more common in towns but pushing into the country; noxious species; "like the poor, always with us, at Iron Mountain" (E. E. Brewster); "already at Mackinac Island" (S. E. White); eats grain, often very extensively, especially peas, vegetables and insects; drives away our native birds; is very filthy about houses; a three cent bounty is thinning its ranks, and often, through incorrect determination, the ranks of other Sparrows, etc. (see bulletin No. 62, Michigan Experiment Station, or report of the Hichigan State Board of Agriculture. 1890. p. 275 ); breeds abundantly; it is reported that thirty young may be reared from a single pair in a season; nests about cornices, etc., about houses and concealed places, "often in Grand Rapids in trees, the nests being bulky and open on the side " (R. H. Wolcott); eggs four or five, occasionally six, very rarely nine; soiled white specked with brown. For full account of this bird-pest see excellent report by the United States Department of Agriculture.

Genus AMMODRAMUS Swats.

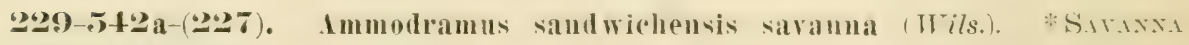
SPARROW.

Not uncommon; migrant; Dr. Atkins took it May 10, 1882; " not sure that it breeds in Michigan" (A. H. Boies); "Monroe County, but does not breed, seeing a bird in summer is not sure proof that it breeds" (Jerome Trombley); "it is evidently a transient" (Dr. M. Gibbs). 


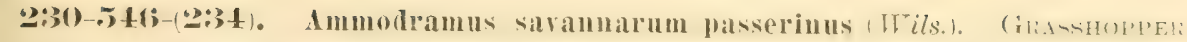

Sparrow; Yellow-winged Sparrow; Cricket Sparrow.

Summer resident; southern part of the state (Prof. J. A. Allen); "breeds" (Gibbs" Bird of Michigan); "Hillsdale and Lenawee Counties" (A. H. Boies); "inereasingly abundant at Plymouth" (J. B. Purdy); Jerome Trombley has found it breeding in a meadow in Monroe County; "is becoming very common as the forests are cleared off " (Dr. M. Gibbs); two of its common names come from its stridulating note.

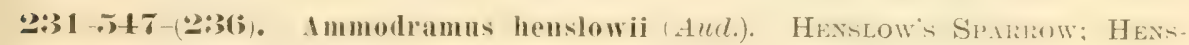
Low's Bunting.

Rare; Northwestern Indiana, Lake County (Butler's Birds of Indiana); included in the list of Michigan birds by both Boies and Covert. Mr. A. W. Butler thinks that this and also Leconte's Sparrow Ammodramus leconteii will both be found to belong to our Michigan fauna.

23:2-54!)a (2+1). Immodramus candacutus nelsoni Allen. NFLoxis Sparion: Nelson's Sharp-Tailed Finch.

Rare; two specimens reported taken Oct. 5, 1878, in Gibbs' Michigan Birds; reported from Northwestern Indiana, where perhaps it is a summer resident (Butler's Bird's of Indiana).

GeNUS CHONDESTES SWAIN.

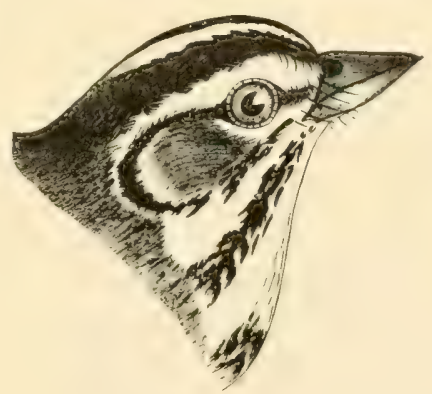

Lark Sparrow, natural size.

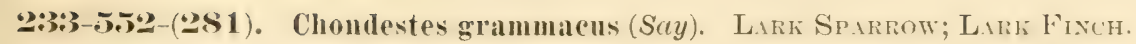

Not rare in northern part of the state; summer months; "rare and irregular at Ann Arbor" (Dr. J. B. Steere); "Sault Ste. Marie" (A. H. Boies); "rare in Monroe County, where two nests have been found" (Jerome Trombley); May to Aug.; arrives in Hlocks; "breeds irregularly and often very locally" (Dr. W. C. Brownell); "breeds in the Northern Peninsula" (Prof. Ludwig Kumlein); nests in June on the ground or in bushes; eggs four to six, white with irregular lines of black or brown; "locally common, breeds" (Gibbs). Dr. Atkins makes no mention of this bird but we have taken it here.

GENUS ZONOTRICHIA SWAIN.

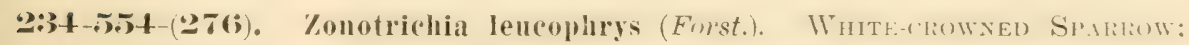
White-browed Sparrow; White-Browed Crowned Sparrow.

Common; throughout the entire state; May and October; "Mackinac Island" (S. E. White); "Keweenaw Point" (Kneeland); "breeds in the Northern Peninsula" (Lud13 
wig Kumlein); "doubtful if it breeds in Northern Peninsula" (Dr. A. K. Fisher); migrant in Lower Peninsula; "less common in Monroe County than the Whitethroated Sparrow " (Jerome Trombley); solitary; "generally gregarious during migration" (Dr. M. Gibbs).
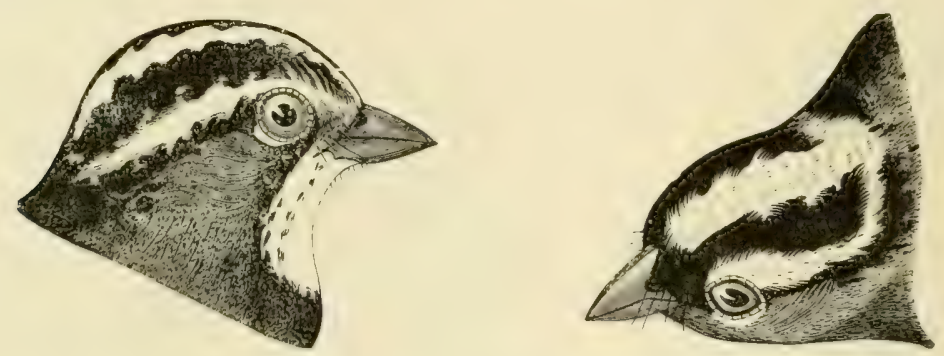

White-throated Crown Sparrow, natural size.

2:35-5.TS (275). Zonodrichia albicollis (Gmel.). *Whote-thontem Sparkow.

Abundant; throughout the entire state; September, April and May; migrant; not uncommon migrant at this place; "though a migrant at Ann Arbor, nests abundantly at Petoskey as late as July" (Dr. J. B. Steere); "common in Grand Traverse County" (M. L. Leach); "common at Iron Mountain" (E. E. Brewster); "very abundant on Keweenaw Point" (Kneeland); "breeds freely in Northern Peninsula" (Prof. Ludwig Kumlein); "summer resident as far south as Grand Rapids" (Dr. M. Gibbs); S. E. White reports this as breeding abundantly at Mackinac Island; eggs four to five; beautiful singers; usually seen in flocks.

GENUS SPI/ZELLA BONAP.

236-559-(268 part). Spizella monticola (Gmel.). *Tree Sparrow.

Very common throughout the entire state; "often in flocks with the Junco Snow Birds; "common at Iron Mountain" (E. E. Brewster); "Keweenaw Point" (Kneeland); winter resident; October to A pril; Hocks.

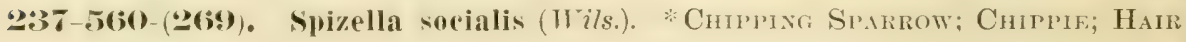
BIRD.

Very common; throughout the state; April to October; "Mackinac Island" (S. E. White); "common at Iron Mountain" (E. E. Brewster); "not seen in the Northern Peninsula" (A. H. Boies); "Keweenaw Point" (Kneeland); breeds abunclantly; nests in May and June, in orchard trees, evergreens, thorn bushes, etc., occasionally in buildings, "sometimes on the ground" (Dr. J. B. Steere); eggs three to five, bluish green with specks of black and obscure brown; migrate south in flocks; one of our best lnown and most friendly Sparrows.

238-561-(272). Spizella pallida (Swain.). Clay-COLORED SPARrow.

"Rare in Western Indiana and Northern and Western Illinois, probably visits Michigan" (A. W. Butler); "breeds in Upper Peninsula" (Prof. Ludwig Kumlein); "doubtiul if it breeds in Northern Peninsula" (Dr. A. K. Fisher); "a very rare migrant" (A. B. Covert's Birds of Washtenaw County, Michigan).

239-5(33-(271). Spizella pusilla (Wils.). *Fiedd Sparrow.

Exceedingly abundant; throughout the entire state; " not abundant at Ann Arbor" (Dr. J. B. Steere); "rare in Wayne County" (B. W. Swales); "abundant in Monroe 
County" (Jerome Trombley); from April to October; "Mackinac Island" (S. E. White); nests in May, in bushes or on the ground; eggs three to five, grayish white, specked with brown; more shy than the Chipping Sparrow. This delightful singer is a favorite with all lovers of nature.

GENUS"JUNCO WAG.

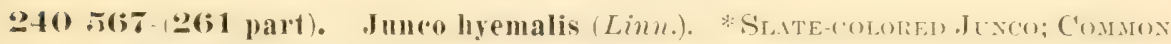
Snow Bird; Junco; Black Snow Bird.

Very common; flocks; winter; more common in spring; not rare in summer, north; "summer resident in Montealm County, but a migrant at Ann Arbor" (Dr. J. B. Steere); "Monroe County from early spring to May" (Jerome Trombley); "common at Iron Mountain" (E. E. Brewster); breeds in the northern part of the state; "builds in Northern Peninsula" (H. Nehrling): "Keweenaw Point" (Kneeland); " mests at Traverse City, in excavations under logs" (L. W. Watkins); "in bushes two to six feet high" (Gibbs); "on the ground" (Coues); or "hole in stump" (Samuels); eggs four, white with reddish specks; reported by Dr. Atkins at Locke July 8, 1879, and by C. W. Gunn at Grand Rapids, a pair apparently breeding July 13, 1878 (Bull. Nuttall Ornithological Club, Vol. IV. p. 238); Mr. S. E. White says this bird may breed in Kent County, as he has taken it in June. These Snow Birds often appear in quite large flocks.

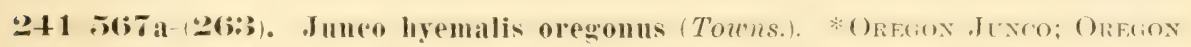
Snow Bird.

"A ccidental visitor" (Dr. M. Gibls); rare; Dr. Atkins reports taking this bird twice in April. This is quite probably an error. Prof. A. W. Butler thinks these notes may refer to Junco hyemalis shufeldti, which has been taken at Lafayette, Ind.

(YiENUS MELOSPIZA BAIRD.

\section{2-581-(244). Melospiza fasciata (Gmel.). *Soxc Sparrow.}

Very common; throughout the entire State; from early spring till late fall; occasional in February; "a few remain through the winter in Monroe County" (Jerome Trombley); "Mackinac Island" (S. E. White); "common at Iron Mountain" (E. E. Brewster); breeds; "Keweenaw Point" (Kneeland); "rears two or three broods a season" (Dr. W. C. Brownell); nests in April and May and August, in bushes, occasionally ten feet high, "have been found in holes of apple trees" (Davie), or on the ground, often surrounded with snow; eggs four or five, Eometimes six and very rarely seven. R. H. Wolcott reports a nest at Ann Arbor, 1892. with seren sparrow eggs and one cow bird's egg, grayish or bluish white, thinly, rarely thickly, dotted with varying shades of brown; beautiful singer; very desirable bird. This is a great favorite with all lovers of birds. I have seen these birds take the half grown bark lice clean, from the linden twigs, in early spring.

\section{3-58:3-(642). Melospiza lincolni (Aud.). Lincoln's Sparkow.}

Very rare; Dr. M. Gibbs reports two specimens taken May 1875, and September 28 and October 9, 1879. and several specimens more recently; E. L. Moseley reports one taken at Grand Rapids in 1887; "should be found breeding in Michigan " (A. W. Butler); "breeds in Northern Peninsula" (Prof. Ludwig Kumlein). 
244 5St-243). Melospiza georgiana (Lath.). Swamp Sparkow.

Not rare; probably throughout the State; April and August; "common at Ann Arbor, nesting in the open swamps" (Dr. J. B. Steere); "nests freely about swampy lakes at Plymouth" (J. B. Purdy); "Southern Michigan and Upper Peninsula" (A. H. Boies); "very common in Kent County, have taken the eggs and seen thousands of the birds" (S. E. White); nests on ground usually in swamps; F. M. Falconer reports taking a nest at Hillsdale, three feet from the ground; eg $y_{s}$ four to five, bluish or grayish white, specked with brown.

GeNus PASSERELLA SWAIN.

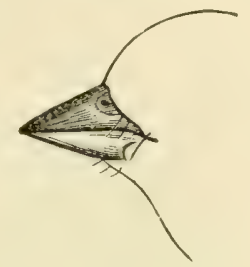

Fox Sparrow, natural size.

245-585-(282). Passerella iliaca (Merr.). *Fox Spariow.

Common; throughout the-state; migrant; "common migrant at Iron Mountain"

(E. E. Brewster); "taken at Ann Arbor" (Dr. J. B. Steere); "an abundant transient" (Dr. M. Gibbs); March and April. and October and November; "Mackinac Island" (S. E. White); "Keweenaw Point" (Kneeland); a very beautiful singer.

Gexus Pipilo Vieill.

246-5S7-(301). Pipilo erythrophthalmus (Limn.). *Towhee; Towhee Buntinc; Chewink; Marsh Robin; Ground Robin; Jewee; Joe-wink.

Very common; throughout the state; March to October; reported at Ann Arbor by F. L. Washburn in December (The Auk. Vol. VI. p. 279); Prof. James Satterlee saw it at Greenville the last of November, 1892; "Nackinac Island" (S. E. White); breeds; "very common at Iron Mountain " (E. E. Brewster); nests in June and July, in bushes. low trees, on grass tufts, near the ground, or on the ground. Dr. Atkins once found a nest on a beech knot, one foot from the ground; eggs three to five, very variable, usually grayish or pinkish white, specked with reddish brown.

GeNus CARDINALIS Bonap.

247-5!):3-(29)9). Cardinalis ('ardiualis (Linn.). *armida: Camdxal Ginosbeak: Virginia Red Bird.

Very rare; "never seen at Ann Arbor" (Dr. J. B. Steere); "have taken a few specimens in Hillsdale and Lenawee Counties" (A. H. Boies); "a few are seen in Monroe County every spring" (Jerome Trombley); "a pair taken in Kent County" (S. E. White); set of eggs taken at Detroit, June 19, 1892 (W. A. Davidson in O. and O., Vol. XVII, 1892, p. 111); Dudley E. Waters took a female in Kent County Aug. 10, 1883, and a male Oct. 24. of the same year. He thinks he saw a joung bird. Mr. Jerome Trombley writes me that a pair have nested in Monroe for two years past. 
Genos Habia Reich.

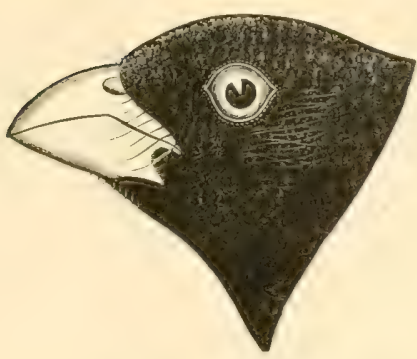

Rose-breasted Grosbeak, natural size.

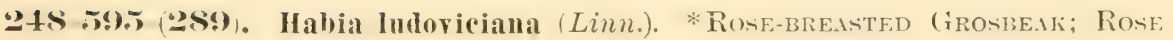
breasted Song Grosbeak.

Common; throughout the Southern Peninsula at least; May to Sept.; "Mackinac Island" (S. E. White); "Keweenaw Point" (Kneeland); "said to be common in hard wood district about Iron Mountain, but I have not taken it" (E. E. Brewster); beautiful singer; often seen in flocks; breeds; Mr. L. W. Watkins informs me that he took a male from a nest of five eggs, on which he was sitting; nests in May and June, in orchards, tall shrubs, forest trees, ete., occasionally high up. E. B. Boies reports a nest in a thorn bush, April 19, 1891. Eggs three to five, bluish green, dotted with brown; "male often incubates" (R. H. Wolcott); very beneficial to the farmer and horticulturists, even eats potato beetles as I have observed on several occasions; Forbes says, (report State Horticultural Society, 1881, p. 204) that 66 per cent of food of many examined, consisted of canker worms; L. W. Watkins informs me that this bird nests at Manchester in low bushes, and also breeds at Traverse City; the song of this bird is delightful.

\section{Genus Passerina Vieill}

249-598-(29)5). Passerina cyanea (Linn.). * Ixdigo Bryting; Indigo Painten Finch; Indigo Bird; Blue Linnet.

Common; throughout the state; May to October; "Mackinac Island " (S. E. White); " common at Iron Mountain" (E. E. Brewster); nests in May and June. in low bushes, often in gardens; eggs four, white with a bluish tinge. Prof, S. A. Forbes (Bulletin No. 3 ) found 78 per cent of the food of several which he examined to be canker worms.

250-600-(29:3 part). Passerina versicolor (Bonap.). *Varied Bintivg.

Dr. Atkins reported taking this rare bird; said to have been observed in Michigan by A. H. Boies. "I think I have seen it" (Dr. Robt. Ridgway); taken by Dr. Atkins May 18, 187t. identified by Ridgway, and now in the collection of Dr. J. M. B. Sill, of Ypsilanti (Dr. Atkins in O. and O., Vol IX, 1884, p. 81).

\section{GENUS SPIZA BONAP.}

251-604-(287). Spiza americana (Gmel.). *Dickcissel; Buack-throated Bunting; Little Meadow Lark.

Very common in some localities in Southern Michigan; rare at the college; "a recent arrival " (Dr. J. B. Steere); May to August; "occasional at Ann Arbor" (Dr. J. B. Steere); "Hillsdale County" (A. H. Boies); breeds; nests usually in bushes, sometimes 
on the ground; eggs four, immaculate, greenish blue; "very common at Manchester, summer of 1892, and the nests were abundant in clover fields" (L. W: Watkins); food largely insects; some examined by Prof. S. A. Forbes (Michigan Horticultural Report 1881, p. 204) showed one-half the food to be canker worms; "not known in Michigan twenty years ago, but becoming more common each year, still rarely found north of $44^{\circ}$. north latitude" (Dr. M. Gibbs).

\section{Fanily TANAGRIDA. Tanagers.}

Highly colored, purely insectivorous.

Genus PIRANGa Vieili.

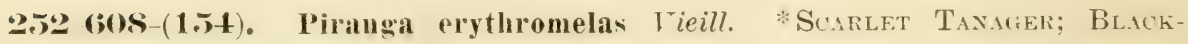
WINGED REDBIRD.

Common throughout Southern Michigan at least; May to August, oceasionally to October; "Mackinac Island" (S. E. White); "common at Iron Mountain" (E. E. Brewster); breeds; nests in May or June, usually on top of horizontal limb, in orchard or small trees, "from twenty to fifty feet from ground on or near ends of swaying branches" (Dr. W. C. Brownell); "often twenty or thirty feet, and rarely, as many as forty feet from the ground" (Prof. Ludwig Kumlein); " nest loose, shallow and coarse" (Prof. J. W. Simmons); eggs three to five, greenish blue spotted with brown; not only a sweet singer, but our most showy bird. Mr. Geo. D. Sones writes mə that the nests are often so poorly built that the eggs may be counted from below looking up through the nests. This bird, of late, comes close to our houses on the college campus.

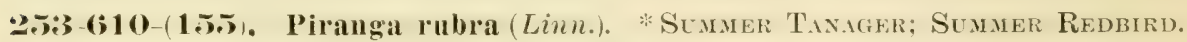

Exceecingiy rare, and only in extreme southern limit; straggler from the south; not so brilliant as the preceding species, and the male has not the black wings. E. L. Moseley reports one from Michigan; "not seen at Ann Arbor" (Dr. J. B. Steere); "never seen in Monroe County" (Jerome Trombley); if ever seen in Michigan an accidental and very rare straggler.

\section{Famlity HiRUNDINID\&. Swallows.} other.

These feed wholly on insects; are very beneficial, and very amiable toward each

\section{GEXUS PROGNE BOIE.}

254-611-(165). Progne subis (Linn.). * Purple Martin.

Common throughout the summer, or was so, prior to the reign of the English Sparrows; throughout the state; "rare in Monroe County" (.Jerome Trombley); "common at Iron Mountain" (E. E. Brewster); "rare outside Detroit, I hunted for four years to find a set of eggs for my collection" (Dr. W. C. Brownell); "common every year at Hubbardston, where it arrives April 7th to 9th each year" (Prof. C. W. Wheeler); "rare and local in Washtenaw County" (Dr. J. B. Steere); "becoming very rare at Plymouth" (J. B. Purdy); "Grand Traverse County" (M. L. Leach); "Mackinac Island" (S. E. White); "nests commonly at Alma, Gratiot County, in the false fronts of stores, where it successfully combats the European Sparrow" (Prof. C. A. Davis); will oppose the European successfully for a time but will finally yield the fort; " nests in Hillsclale in the hoods over electrie lights" (F. M. Falconer); breeds; nests in June, in boxes, holes in trees, etc.; eggs four to six, white; food insects, even Wasps and May Beetles. 
GeNus PETROCHELIDON Cab.

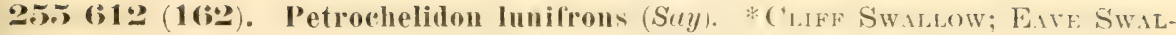
low; Mud Dauber; Square-tailed Barn Swallow.

Very common; throughout the State; May to August; "rare and local in Washtenaw County" (Dr. J. B. Steere); "I have counted one hundred and ninety-three nests under the eaves of one barn, from which I think over two thousand young were hatched in one season" (Dr. W. C. Brownell); "occurs at Chandler's Falls, on the Escanaba river, Upper Peninsula, where it breeds " (L. W. Watkins) "Mackinac Island" (S. E. White); breeds; nests under eaves, on sides of embankments, rocks, etc., preferring the southeast or west side; nests of mud; eggs four to six, white, specked with quite large brown spots. Like other birds that nest around our farm buildings, they are being driven off by the English Sparrow. L. W. Watkins reports an entire brood of albinos.

GENUS CHELIDON FORSTER.

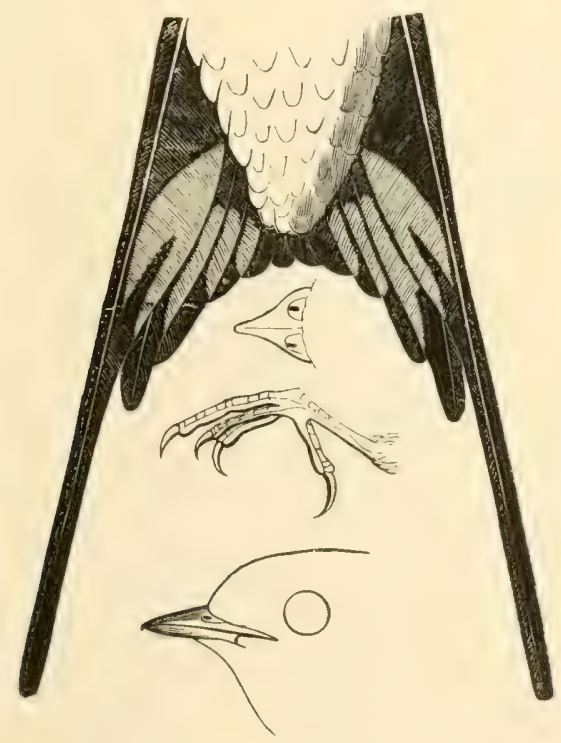

Generic details of Barn Swallow.

256-613-(159). Chelilon erythrogaster (Bodd.). * Barn Swallow.

Very abundant throughout the State; April to August; "Mackinac Island" (S. E.

White); "Keweenaw Point" (Kneeland); breeds; nests in May, in barns and other buildings; "I saw about 300 at my farm at Plymouth, Sept. 4, 1886, and not one after that date" (Dr. W. C. Brownell); two broods and sometimes three; eggs three to six, white, finely spotted with brown, especially at the large end; the tail of this bird is deeply forked. This graceful bird is justly a favorite with farmers and farmers' boys. They are often seen in large flocks just before leaving in early September. 


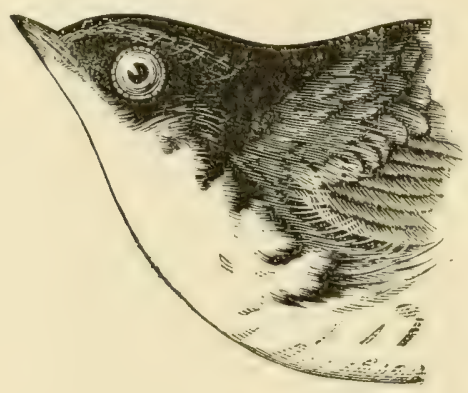

White-bellied Swallow, natural size.

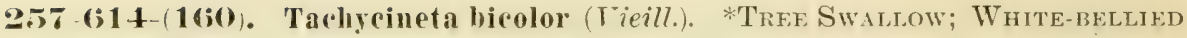
Swallow; Blue-backed Swallow; Field Swallow.

Very common; throughout the state; March or A pril to August; "common at Iron Mountain" (E. E. Brewster); "Keweenaw Point" (Kneeland); breeds; often two broods; nests in May and June, in hollow stumps or holes in trees or buildings, " of ten in stubs in or near water" (Dr. W. C. Brownell); eggs four to seven, occasionally nine, white. I have taken several nests from hollow stumps, and always found them lined with pure white feathers, many of which were too large to have come from this bird.

GeNus CliviCOLA Forst.

2es-616 (16:3). Clivicola riparia (Limn.). *Bank Swallow; Sand Swaliow; Sand Martin.

Very abundant; throughout the state; May to August; "Mackinac Island" (S. E. White); breeds abundantly; nests in May in sand banks; A. B. Covert, of Ann Arbor, once saw it nesting in a crevice of a building (does not Mr. Covert's note refer to the next species?); eggs five or six, white; these birds are very amiable, never seen quarreling; "I have found three nests in branches of one hole" (Dr. W. C. Brownell); Mr. Robt. M. Wolcott saw at White Lake, Muskegon County, July, 1891, an immense colony, numbering hundreds. The bank was very sandy and several nests had a common vestibule near the face of the bank.

\section{Genus STELGidopteryX BaIRd.}

259-(\$17-(164). Stelgidopteryx serripennis (Aud.). * Rovgh-winged Swallow.

Rather common; "in the southern part of the state" (Prof. J. A. Allen); May to August; nests in May, in sand banks, or "buildings or crevices in stone walls" (A. W. Butler); eggs and food habits much as in bank swallows. Dr. Gibbs informs me that the opening to the nest is circular. and not eliptical as it always is in case of the Bank Swallow. He adds further that this bird often builds in erevices in bridges, etc. 
Family AMPELID王. Waxwixgs, etc.

Eesutiful birds; fly in flocks; feed on seeds, insects and fruit.

Subamily AMPELINA. Waxwings.

GENUS AMPELIS LINN.

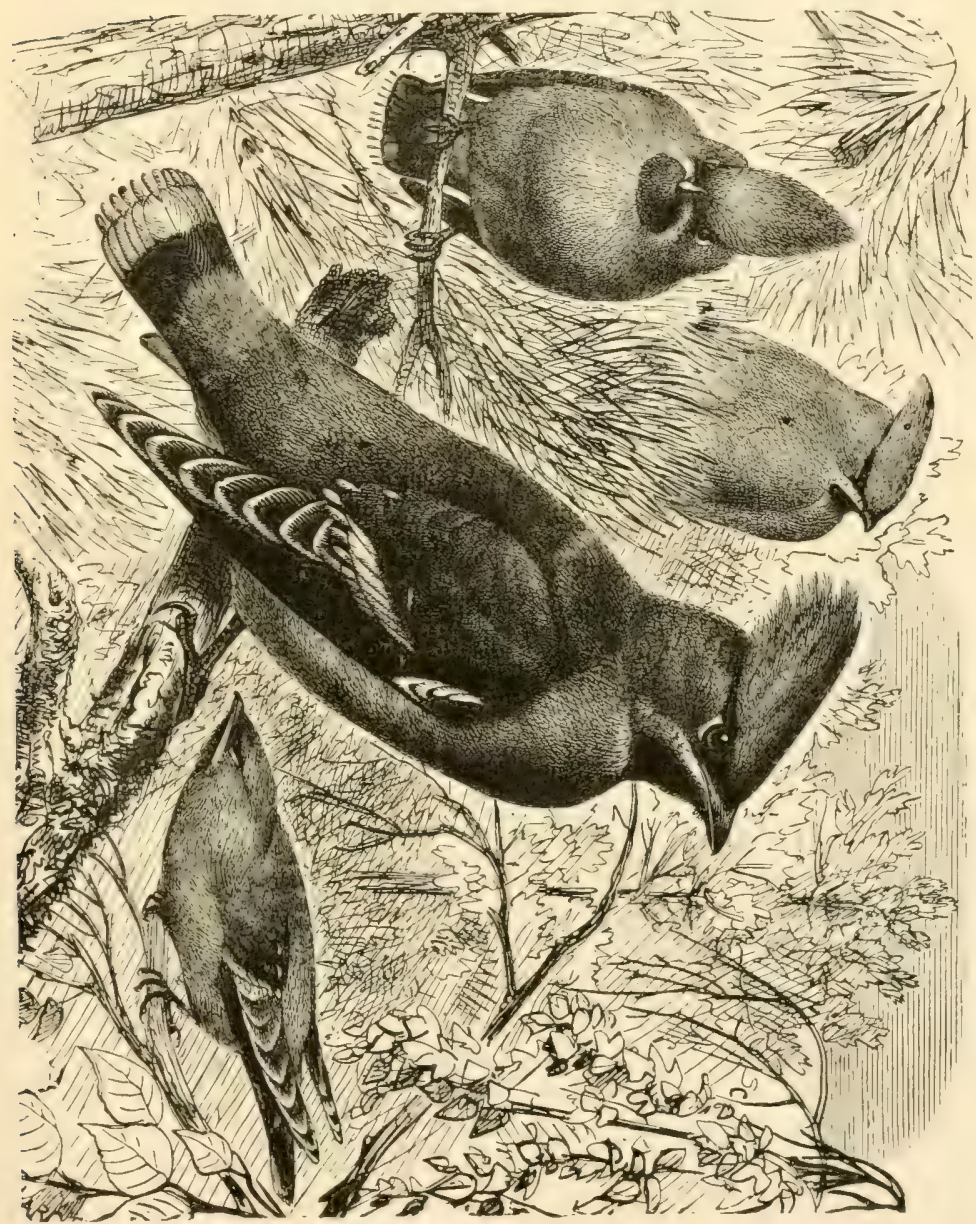

Bohemian Waxwing, one-half natural size.

260-618-(166). Ampelis garrulus Linn. * Bohemitan Waxwing.

Very rare; winter visitor; occasional in spring. Dr. G. W. Topping, DeWitt, Michigan, took from one to three in April of each of the years 1879-80-81 from flocks going north; "in flocks in Kent County nearly every spring, often as many as one hundred" (Dudley E. Waters); does not Mr. Waters refer to the next species? 
Mr. Levi Broas has several in his collection, which he took in Ionia County; "seen in early spring at Bay City in 1851" (N. A. Eddy, in O. and O., Vol. IX, 1884, p. 41); Dr. Atkins took this bird at Locke several times in March and once in April; E. L. Moseley reports two from Michigan; "four seen in Kent County, April 4, 1889" (S. E. White); "often exceedingly abundant in Northern Michigan" (H. Nehrling); "several flocks seen at Charlewix in the fall several years since" (M. L. Leach); "Upper Peninsula" (A. H. Boies); "Keweenaw Point" (Kneeland); "Traverse City" (M. L. Leach). "Has been taken in southern Indiana several times" (A. W. Butler).

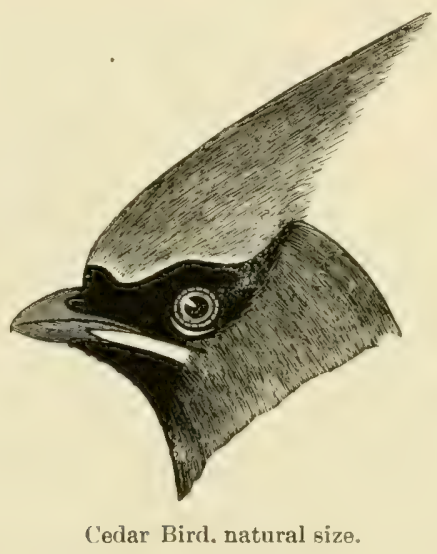

261-619 (167). Ampelis cedrorum (Tieill.). *Cedar Brid); Cedar Wax-ning: Cherry Bird.

Very common; throughout the State; April to August; not rare in winter; embraced in Cabot's Birds of Lake Superior; "common at Iron Mountain" (E. E. Brewster); "Koweenaw Point" (Kneeland); migra 'es frequently for short distances; in flocks; breeds; nests in bushes, trees of the orchard or woodland, etc., in July and August; eggs four to six. light drab or clay white, speeked with black and brown; eats cherries, apple blossoms, berries and insects, "eats three thousand canker worms daily" (Forbes report Michigan State Horticultural Society, 1831, p. :04); "I have seen them feeding extensively on canker worms" (Prof. C. A. Davis); "eat elm beetles and many other insects" (Dr. A. K. Fisher). From a preliminary report by F. E. L. Beal for the United States Department of Agriculture, manuseript kindly loaned to me. I find that 125 stomachs of these birds from 14 states were examined. The conclusions reached were these: 1st, that the Cedar Birds eat a certain amount of insect food at all times, when it can be obtained, aggregating in this case $17 \%$ of the food for the whole year; $2 d$, that the greatest amount of insect food is eaten during the month when fruit is the most abuniant: $3 \mathrm{~d}$, that the greatest number of insects is eaten in the month of May, with a decrease, during the succeeding months until September, when the percentage again rises; th, that the young, while in the nest, are fed to a great extent upon insect food; eats mountain-ash berries, etc., in winter. These beautiful birds do not seem to be exclusively insectivorous, and a flock will destroy an immense number of cherries; Dr. M. Gibbs writes me that he has reared the young, taken from the nests, entirely on fruit. 


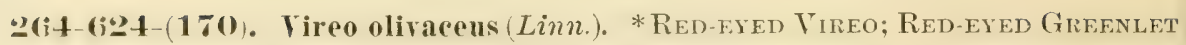

One of our most common birds; throughout the state; frequents parks and woodlands; April to September; included in Cabot's list of Birds of Lake Superior; "Mackinac Island" (S. E. White); E. E. Brewster finds this species very common at Iron Mountain; " Keweenaw Point" (Kneeland); breeds; of ten double brooded; nests in June on the horizontal branches of trees, usually in woodlands, occasionally in orchards; the nest is very beautiful; "nests in Traverse City" (L. W. Watkins); nests suspended. below limb, not hanging like those of Orioles; eggs three to four, rarely five, white, spotted with blackish dots.

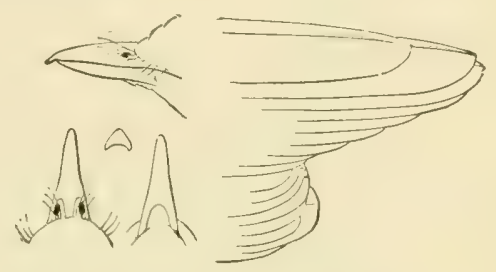

Brotherly Love Vireo, natural size.

2675 (626) (17:3). Vireo philadelphicus (Cass.). *Philddelpha Vireo; Brotherly-Love Vireo; Brotherly-love Greenlet.

Rare; migrant; taken at the college Sept. 11, 1889; "rare in Kalamazoo County" (Dr. M. (iibbs); Dr. M. Gibbs writes me that he has taken it in Kalamazoo and Ottawa Counties; "quite common fall migrant at Mackinac Island, have taken several in Kent County" (S. E. White); we find it not uncommon here th is May, 1893; Forbes found (report Michigan State Horticultural Society, 1881, p. 204) that 35 per cent of food consisted of canker worms.

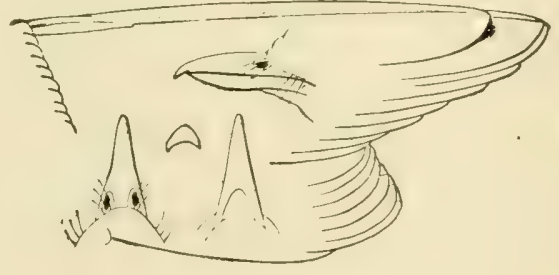

Warbling Greenlet.

266-627-(174, 175). Vireo gilvus (Tieill.). *Warbling Vireo; Warbling Greeniet.

Common throughout the state; April to Sept.; "common at Ann Arbor" (Dr. J. B. Steere); "common at Plymouth" (J. B. Purdy); "Hillsdale and Lenawee Counties and Upper Peninsula" (A. H. Boies); "Mackinac Island" (S. E. White); breeds; has been known io steal material for nest building from King Birds' nests at Plymouth, Michigan (see O. and O., Vol. XIV, p. 93); nests and eggs as in Vireo olivaceus, except nests. are slightly smaller, with softer lining, and the eggs less specked; "one of the very few birds that sing as it sits on its nest " (Dr. M. Gibbs); Forbes found (report of Michigan Horticultural Society, 1881, p. 204) that 35 per cent of food was canker worms; "nests 


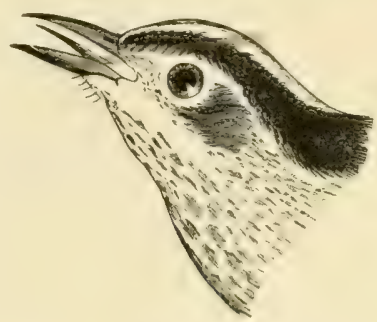

Black and White Creeper, natural size.

270-(6:36-(91, 92). Mniotilta varia (Linn.). Black and White Warmler; Blach And White Creeper.

Throughout the lower Peninsula at least; common; rare in some localities; a pair taken at college by A. B. Cook, May 10. 1893; "Mackinac Island" (S. E. White); breeds; "not observed nesting at Ann Arbor" (Dr. J. B. Steere); "not common but breeds in Monroe County and always on the ground" (Jerome Trombley); "Dennis Nolan found a nest under a $\log$ in Kalamazoo County" (Dr. M. Gibbs); "never found a nest at Plymouth" (J. B. Purdy); "found one nest in Wayne County" (Dr. W. C. Brownell); nests in May, usually on the ground, under logs, very rarely in bollow trees; eggs four or five, white with yellowish tinge, and specked with brown, most of the brown is in the form of a wreath around the large end; eats insects and insects' eggs; very beneficial. This bird reminds us of the Creepers and Titmice, in its climbing along branches in quest of insects.

\section{GENUS PROTONOTARIA BAIRD.}

271-637-(95). Protonotaria citrea (Bodd.). * Prothonotary Warbler; Golden Swamp Warbler; Willow Warbler.

Rare at Lansing; "abundant the last few years in Southwestern Michigan" (Dr. M. Gibbs); "rare along Kalamazoo river in Allegan County" (S. E. White); "Lenawee County" (A. H. Boies); "has not been observed in Monroe County" (Jerome Trombley); breeds; found breeding in Michigan, latitude $42^{\circ}$ north, by K. R. Willhelm; nests in June, in holes in trees, stumps etc.; "always nests near water, usually over it" (Dr. M. Gibbs); "at St. Joseph".(Butler"s Birds of Indiana); "not rare in Cass County, found in swamps and thickets" (Prof. J. W. Simmons). For interesting account of its migration routes, see "Notes on the range of the Prothonatory Warbler in Indiana," by Amos W. Butler, O. and O., March. 1858, pp. 33-34; also "Proceedings Indiana Academy of Science, 1891, p. 165.

Genus helmitherus Rafix.

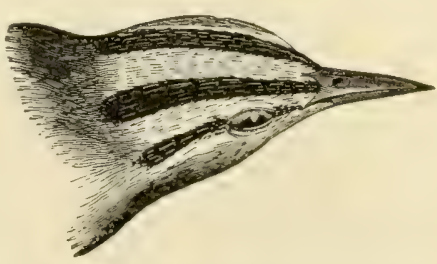

Worm-eating Warbler, natural size. 
272-639-(96). Ielmitherus rermivorus (Gmel.). Worn-eativg Warblak.

Rare; "Lenawee and Hillsdale Counties" (A. H. Boies): "Northern Indiana, song rery like that of Chipping Sparrow" (A. W. Butler).

GENus HELMINTHOPHILA RIDG.

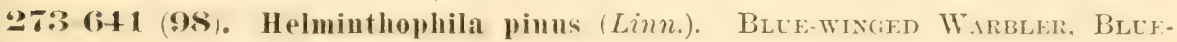
Wingen Yeltow Warbler.

Kare; "summer sojourner" (Gibbs' Birds of Michigan); "very rare in Monroe County, where it is transient, only two ever seen " (Jerome Trombley); "locally distributed" (Dr. M. Gibbs); breeds; nests in May on the ground; eggs four to five; "this and the preceding species are very rare in Northern Indiana" (A. W. Butler); S. E. White took two of these on Mackinac Island July 1, 1889. Helminthophila leucobronchialis (Brewst.), which has been reported from Michigan, (The Auk, Vol, I, pp. 359-363), is now regarded as a hybrid between this and the next species, as I learn from Prof. J.A. Allen. The same is doubtless true of the bird described as Helminthophila gunnii in the Grand Rapids Daily Democrat, June 1, 1879.

274-642-(102). Helminthophila ehryoptera (Limn.). *Golden-winged WarbLer; Blue Golden-winged Warbler.

Throughout the state; May to August; "common summer resident in Monroe County" (Jercme Trombley); "Mackinac Island" (S. E. White); "have found nests with four eggs at Plymouth" (J. B. Purdy); breeds; nests in May, on the ground; eggs four to five, rarely six; one of ,our most beautiful warbiers. Dr. M. Gibbs writes me that he has taken many nests in Kalamazco County; Mr. Davie says that Mr. J.P. Norris has a set of four eggs from Monroe County, Mich., and a set of five from near Detroit (Nests and Eggs of North American Birds, p. 360).

275-645 (106; part). Helminthophila ruficapilla (Wils.). *Nashrille Warbere.

Rather common; migrant; May; "very common migrant in Lake County, Indiana, and also a rare resident" (Dr. Brayton's Birds of Indiana, p. 105); "often common in Monroe County" (Jerome Trombley); "Mackinac Island, where it breeds" (S. E. White); "common at Iron Mountain" (E. E. Brewster); possibly breeds; nests in June, on the ground; eggs three to five; feeds on insects; beneficial.

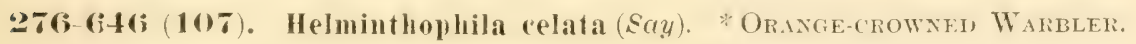

Rare; May and September; migrant; this one is easily mistaken for the last mentioned species; "Plymouth" (J. B. Purdy); "common but migrant at Ann Arbor" (Dr. A. K. Fisher); reported sereral times by Dr. Atkins at Locke.

\section{7-6it7-(109). Helminthophila peregrina (Hils.). *Texpassf: Warblar.}

Not common; "rare in Monroe County" (Jerome Trombley); taken at Plymouth by J. B. Purdy; May and September and October; migrant; "breeds near L'Anse, Upper Peninsula" (Prof. Ludwig Kumlein); often mistaken for the Nashvilie Warbler. S. E. White finds this common in late September, and late Octoter at Mackinac Island, where it is also a migrant. 
Genus COMPSOTHLYPIS Gab.

278 648 (9)3). ('ompsothlypis americana (Limn.). *P.acl WARELET; BLLE

YeLLOW-BACKED WARBLER.

Rare; May and June; "Lenawee and Hillsdale Counties" (1. H. Boies); "Mackinac Island" (S. E. White); occasionally breeds; nests in June, in trees, "often in a bunch of lichens" (Dr. A. K. Fisher); nest elaborate; eggs four to tive, white with yellowish tinge and specked with brown. "Never found a nest at Plymouth" (J. B. Purdy); "this bird is a transient in Monroe County, where it is becoming very rare" (Jerome Trombley).

Gencs Dendroica Gray.

279-650-(126). Dendroica tigrina (Gmel.). Cape May Warbler.

Not rare in spring and autumn; "common in Kent County in spring migrations, not rare in autumn; migrant; frequents the orchards and pines" (S. E. White); "see them every year in Kent County from May 7 to May 15, have killed fifteen in one day" (Dudley E. Waters); I have it reported from Thunder Bay Island; " Lenawee County ". (A. H. Boies); "Monroe County, very rare, only two seen" (Jerome Trombley); "Mackinac Island" (S. E. White); in Cabot's list of Birds of Lake Superior; "known to breed near Green Bay, Wisconsin" (Prof. Ludwig Kumlein).

280-(i52-(111 part). Dendroica mstiva (Gmel.). *Yed.low Warbler; Yellow Bird; Summer Yellow Bird.

Our most common resident warbler; April and May to August and September; taken at college by A. B. Cook, May 10, 1893, who finds it common; "not observed in Upper Peninsula " (A. H. Boies); "Mackinac Island" (S. E. White); " taken at Iron Mountain" (E. E. Brewster); "Keweenaw Point" (Kneeland); breeds; nests in May, in thick foliage, in bushes or small trees. especially in willows along streams; nests exquisite; eggs four, oceasionally five, yellowish white or greenish gray. specked with brown; J. B. Purdy reports a full set of albino eggs; Forbes found (see report of Michigan Horticultural Society, 1881. p. 204) that 66, of the food of several birds examined consisted of canker worms. "It feeds extensively on the larvæ of elm beetles" (Dr. A. K. Fisher). This is an excellent little bird friend.

2S1-(554-(117). Dendroica carulescens (Gmel.). *Black-throated Blé WARBLER.

Common; migrant; two pairs taken at college by A. B. Cook May 10, 1893; "Mackinac Island" (S. E. White); possibly breeds north; "C. W. Gunn found it breeding in Ottawa County" (Dr. M Gibbs); " migrant in Southern Michigan" (Jerome Trombley); "taken at Iron Mountain in spring" (E. E. Brewster); nests in low brushwood; eggs four to five, rosy white, and like those of most warblers specked with brown.

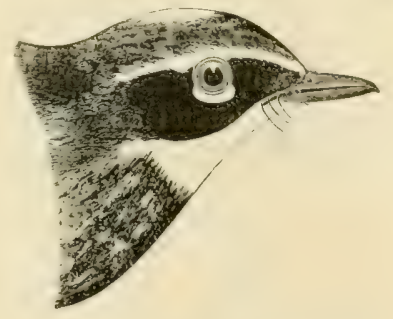

Yellow-rumped Warbler, natural size 
2S.65.5-(119). Dendroica coronata (Linn.). *MYrTLE WARBLER; YFLLOWRUMPED WARBLER; Golden-Crown Warbler.

Very common; throughout the entire state; several taken in May, 1893, at college, by A. B. Cook; migrant in the southern part of the state; one nest found near Detroit by B. W. Swales (O. and O., Vol. XVI, 1891, p. 148); April or May and October; "our earliest migrant at Morrice" (Dr. W. C. Brownell); "our earliest warbler at Iron Mountain, taken April 16, 1890" (E. E. Brewster); breeds north; "nests at Mackinac Island in July and August" (S. E. White); "Kerveenaw Point" (Kneeland); "nests in evergreens, eggs four" (J. W. Simmons).

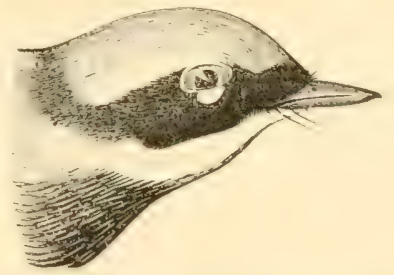

Black and Yellow Warbler, natural size.

283-657-(125). Deudroica maculosa (Gmel.). *Magnoli Warbler; Brack AND YELLOW WARBLER.

Common; migrant; "quite common migrant in Monroe County" (Jerome Trombley); "common but shy in Lenawee County" (A. H. Boies); taken by E. E. Brewster at Iron mountain; "Keweenaw Point" (Kneeland); May and June, and September and October; embraced in Cabot's Birds of Lake Superior; "abundant at Mackinac Island where it breeds" (S. E. White); "builds in Northern Michigan" (Davie's Nests and Eggs of North American Birds); a beautiful species.

284-65s-(11S). Dendroica carulea (Wils.). *Cerulean Warbler; Blue WARBLER.

Rather common; "Lenawee County" (A. H. Boies); "DeWitt" (Dr. G. W. Topping); "next to Yellow Warbler the most common warbler breeding in Nonroe County" (Jerome Trombley); "have only taken one in Kent County" (S. E. White); May and June; very handsome; breeds; "several nests taken in Wayne County" (Dr. W. C. Brownell); nest taken near Detroit June 19, by W. A. Davidson (O. and O., Vol. XVII, 1892, p. 111); nests in May in high trees; this is quite common in the thickets about the college.

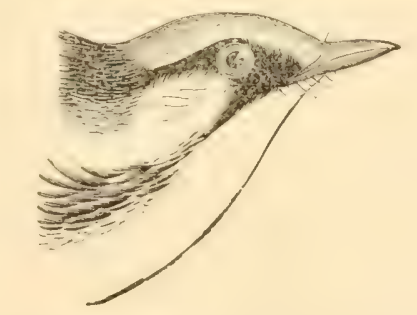

Chestnut-sided Warbler, natural size.

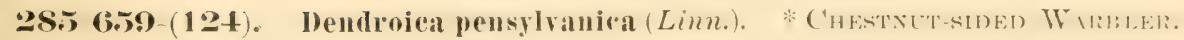
Very common, some seasons; throughout the entire State; "migrant at Plymouth" (A.B. Purdy); "Mackinac Island where it breeds" (S. E. White); "very common resident 
at Iron Mountain" (E. E. Brewster); "more commonly found in swamps" (Prof. J. W. Simmons); several taken at college-the first May 10-by A. B. Cook in May, 1893. He finds it the most common Warbler; breeds; "nests found near Detroit by B. Swales" (O. and O., Vol. XVI, 1891, p. 148). Dr. M. Gibbs writes me that he once found five nests in one day in Kalamazoo County, where it rarely builds now; said to be two brooded in Canada; nests in June, in low bushes; eggs four or five. This species rears many Cow Birds.

286-660-(123). Dendroica castanea (Wils.). *BaY-breasted Warbler.

Rather common; migrant in Southern Michigan; May and October; "Lenawee County and Northern Peninsula" (A. H. Boies); "breeds in Northern Peninsula" (Prof. Ludwig Kumlein); male taken at college May 20, 1893, by A. B. Cook; "breeds in Northern Michigan" (Davie's Nests and Eggs of North American Birds, p. 373). S. E. White writes me that he shot immature specimens at Mackinac Island as late as July; we have taken this species here more frequently in the spring; Dr. Atkins reports this species as very rare at Locke. Its song is very charming.

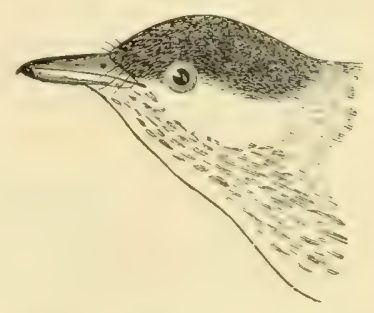

Black-poll Warbler, natural size.

2S7-661-(122). Dendroica striata (Forst.). * Black-POLL WARBLER.

Common; migrant; a pair taken by A. B. Cook at the college May 20, 1893; "Monroe County, some years very common" (Jerome Trombley); "Mackinac Island" (S. E. White); "Keweenaw Point" (Kneeland); "Iron Mountain May 24, 1881" (E. E. Brewster); "common spring migrant in Upper Peninsula" (Prof. Ludwig Kumlein).

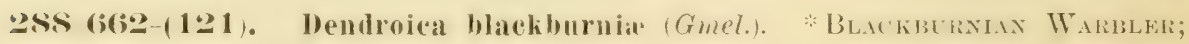
Orange-throated Warbler; Hemlock Warbler.

Rare; "rare migrant in Monroe County" (Jerome Trombley); rare in summer; throughout the Southern Peninsula; "Mackinac Island" (S. E. White); "common at Iron Mountain" (E. E. Brewster); "Hillsdale and Lenawee Counties" (A. H. Boies); "DeWitt" (Dr. G. W. Topping); A. B. Cook took one male and two females of this handsome Warbler at the college May 18, the only ones seen up to this date, May 26, 1893; breeds north; "nests in Northern Peninsula" (Prof. Ludwig Kumlein); "has been found breeding in Southern Michigan where nests have been taken in pine trees, at an elevation of forty feet" (Davie's Nests and Eggs of North American Birds, p. 373); "B.F. Syke found two nests in Kalamazoo County, both quite high in tamarack trees" (Dr. M. Gibbs).

28!) 66:3a-(1:30). Dendroical dominiea albilora Baird. Srcanore Warbler; White-Browed Y'FLLOW-ThRoated WatrLer.

Rare; "early migrant" (Dr. M. Gibbs); "rather rare summer resident, breeds, nests in tall sycamores on Raisin river" (Jerome Trombley); Dr. M. Gibbs writes me that he 
has found one nest in Kalamazoo County; "said to be often common about Detroit" (Butler's Birds of Indiana).

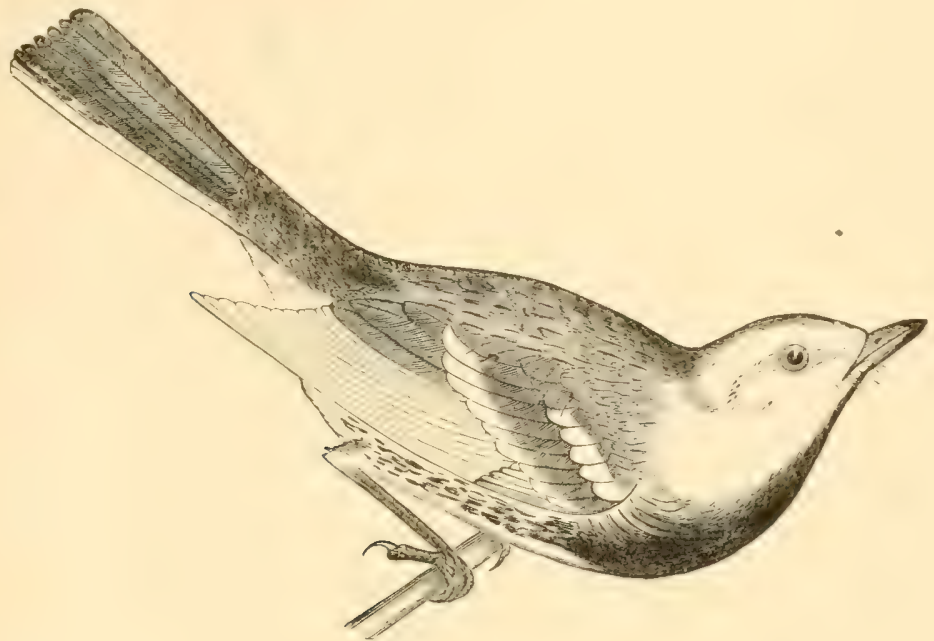

Black-throated Green Warbler, natural size.

290-667-(11:2). Dendroica virens $($ Gmel.). * Black-throated Green Warbler.

April and May, and August and September; usually a migrant south; nests north of Montcalm County; "breeds sparingly in Kent County but abundantly at Mackinac Island" (S. E. White); "Keweenaw Point" (Kneeland); "taken in spring at Iron Mountain" (E. E. Brewster); "nests abundantly in Northern Peninsula" (Prof. Ludwig Kumlein); "breeds in Northern Michigan" (Davie's Nests and Eggs of North American Birds). This bird has been taken in Montcalm County by Dr. J. B. Steere, and in Ionia County by Mr. Levi Broas.

391-670-(131). Dendroica kirtlandi Baird. Kirtland's Warbler

"Rare straggler" (Dr. M. Gibbs); "one from Battle Creek May 11, 1833, identified by Robt. Ridgway; taken by Mr. Knapp at Ann Arbor May, 1888 (The Auk, Vol. VI, p. 279); one from Straits of Mackinaw, identified by Dr. C. Hart Merriam (The Auk, Vol. 1, pp. 376 and 389); in 1879 nine specimens known, the fifth and ninth taken by A. B. Covert in Washtenaw County (H. A. Burdie in Bull. Nuttall Ornithological Club, Vol. IV, p. 185); reported by Dr. C. Hart Merriam from Straits of Mackinaw, May 21. 1885 (The Auk, Vol. I p. 376).

292-671-(1:34). Dendroica vigorsii (Aud.). *Pane Warbler; Pine-dreeping WARBLER?

April and May and September and October; J. E. Nichols of Lansing has taken these often in October; not observed in Monroe County" (Jerome 'Trombley); "very common at Iron Mountain, and probably a summer resident" (E. E. Brewster); breeds north; "nests at Traverse City" (L. Whitney Watkins); "found all summer in Kent County, probably breeds" (S. E. White); "song resembles that of sparrow and is not warbler like" (Dr. M. Gibbs). 
293 672-(13:2). Dendroica palmarum (Gmel.). * P.tm W.arbler; Yellow Renpolled Warbler; Wag-tailed Warbler; Titlark Warbler.

Very common migrant; May and October; flocks; "occurs at Mackinac Island" (S. E. White); "E. E. Brewster has taken it at Iron Mountain; one of our most common and beautiful migrants.

294-67:3-127). Dendroica discolor (Vieill.). Pratrie Warbler.

"Rare migrant, breeds north of $44^{\circ}$ north latitude" (Dr. M. Gibbs); " not observed in Monroe County" (Jerome Trombley); " breets in Michigan " (Darie); Dr. M. Gihbs writes me that he has taken the eggs; found very common at Mackinac Island by S. E. White who has specimens taken there; Prof. J. A. Allen writes me that this bird does not go north of Central Michigan; Dr. M. Gibbs collected nest and two eggs May 26, 1879, in Ottawa County (Bul. Nutt. Orn. Club, Vol. IV, p. 186).

Genus SEIURUS Swains.

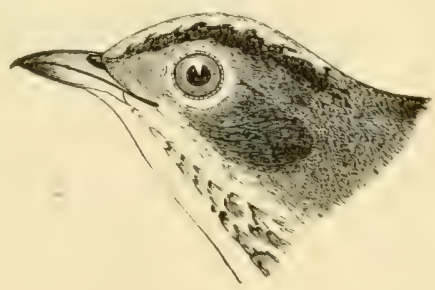

Oven Bird, natural size.

295-674-(135). Seiurus aurocapillus (Linn.). * Oven Brrd; Golden-orowned Thrush; Wood Wagtail.

Very common; throughout the Southern Peninsnla at least; April to September. rarely to October; " usually seen on the ground" (Prof. J. W. Simmons); "abundant at Ann Arbor" (Dr. J. B. Steere); "common in Lenawee and Hillsdale Counties". (A. H. Boies); "Mackinac Island" (S. E. White); taken at Iron Mountain by E. E. Brewster; breeds; nests in June on the ground, often under log; nest oven-like, hence common name of bird; nests common near marshes about the college; eggs four to six. 'This bird is retiring and usually found in dense thickets; "sings at all times of night" (Samuels). When we drive this bird from the nest it feigns lameness and flutters away to lure us from its eggs and young. This bird rears very numerous Cow Birds.

296-675-(136). Seiurus noveboracensis (Gmel.). * Water Thresh; Sarald-ibleded Water Thrush; Water Wagtail.

Rare; migrant; April and May; "rare transient in Kalamazoo County" (Dr. MI. Gibbs); "very rare in Kent County, one taken May 9, 1891 " (S. E. White); "Keweenaw Point" (Kneeland); "taken in Hillsdale County" (A. H. Boies); "rare in Monroe County" (Jerome Trombley); frequents dense thickets in swamps; "breeds in Northern Indiana where it is a rare summer resident" (A. W. Butler); nests in June, among roots of turned up trees, in marshes or under stumps, logs, etc.; eggs four to six, delicate cream, densely specked with reddish brown. 


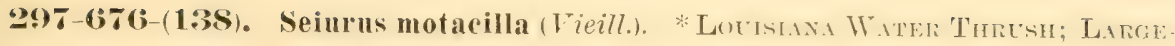
billed WaG tail Warbler.

Not uncommon, especially in the southern part of the state; April to August; "common in Kálamazoo County" (Dr. M. Gibbs); "very common in Kent County" (S. E. White); breeds; nests on the ground, under logs, or as in the preceding species; eggs as in the preceding. Mr. Jerome Trombley writes mo that this is the common "Water Thrush" of Monroe County.

Genus GeOThlypis Car.

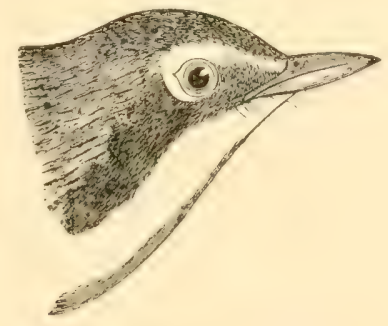

Kentucky Warbler, natural size.

298-67-7-(140). Geothlypis formosa (Wils.). * Kentuchy Warbler.

Exceedingly rare; Dr. Atkins reports taking one specimen June 24, 1878; Dr. M. Gibbs reports one specimen taken by him in Kalamazoo County.

399-67S-(139). Geothlypis agilis (Wils.). *ConneCtICUT WARbler.

Exceedingly rare, but becoming more common; "one of our rarest Warblers" (Dr. M. Gibbs); May and June; migrant; “" first taken May, 1879, in Kalamazoo, Washtenaw. Ottawa and Ingham Counties within a week" (Dr. M. Gibbs); "one taken August 30, 1889, and the same date in 1890, and one taken a week later in Kent County" (S. E. White); Mr. Chas. W. Guun reports one from Ingham and one from Ottawa County (Bull. Nuttall Ornithological Club. Vol. IV, p. 123); this is one of the latest Warblers to arrive in the spring.

\section{:300-679-(142). (ieothlypis philadelphia (Wils.). * Mormixi Wrimer.}

Occasionally quite common; May to August; "Hillsdale and Lenawee Counties" (A. H. Boies); "migrant at Plymouth" (J. B. Purdy); "rare in Monroe County" (Jerome Trombley); "rare in Kalamazoo County" (Dr. M. Gibbs); "Mackinac Island" (S. E. White); embraced in Cabot's Birds of Lake Superior; “ Iron Mountain. May, 1888 " (F. E. Brewster); "breeds north on edge of pinery" (Dr. M. Gibbs). Dr. Gibbs writes me that it is abundant in second growth clearings in the pine region north of 44 degrees north latitude; nest and eggs as in next species. Taken here by A. B. Cook, May 17, 1893.

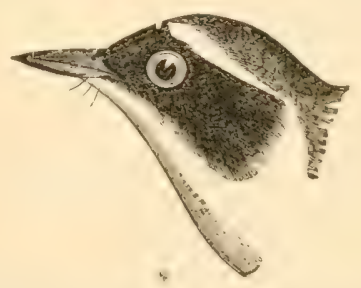

Maryland Yellow-throat, male, natural size. 
301 (3S1-(1+1 part). (ieothlypis trichas (Linn.). * MLARYLAND YelLow-THROAT: Yellow-throated Ground Warbler.

Very common; throughout the state; May to August; "abundant at Ann Arbor" (Dr. J. B. Steere); "common at DeWitt" (Dr. G. W. Topping); reported from Hillsdale and Lenawee Counties and at Sault Ste. Marie, July 16, 1892, by A. H. Boies, who thinks it breeds in the Northern Peninsula; "common at Mackinac. Island" (S. E. White); "common at Iron Mountain" (E. E. Brewster); breeds; "two broods" (Dr. W. C. Brownell); nests from May to July, on the ground or in low thickets; nests often arehed over; eggs four to six, clear white specked with reddish dots, though quite variable in size, form and markings; one of our finest singers and justly a farorite.

GENUS ICTHRIA VIHILL.

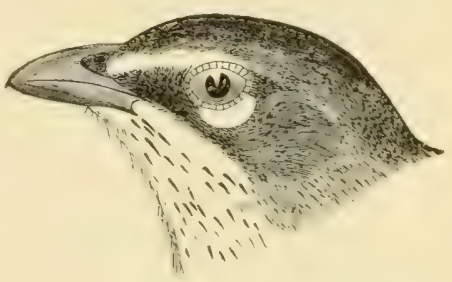

Yellow-breasted Chat.

302-6S:3-(14). Icteria virens (Linn.). * Yellow-breasted Chat.

Exceedingly rare; "occasionally quite common" (Dr. H. A. Atkins); "not observed at Ann Arbor" (Dr. J. B. Steere); "once in Lenawee County" (A. H. Boies); " formerly nested in Monroe County, not seen since 1881" (Jerome Trombley); May to October; breeds; nests in May and June in bushes; eggs four; song varied and beautiful; "ventriloquist" (Butler's Birds of Indiana); "this is a southern species" (Prof. J. A. Allen).

Genes SYLVANIA NutT.

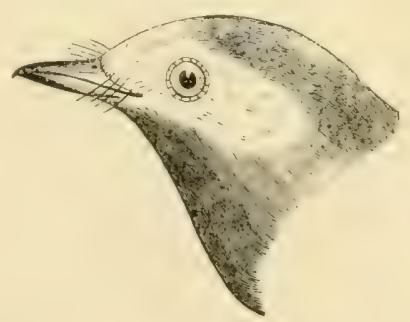

Hooded Warbler, natural size.

:30:3 6s4 (146). Sylrania mitrata (Gmel.). *Hooded Wirnlen; Houden FlyCatching Warbler.

Quite common in southern part of State; generally a migrant; May and October; "breeds plentifully south of $42^{\circ}$, have taken many nests" (Dr. M. Gibbs); "common but transient in Monroe County" (Jerome Trombley); nests in May in low bushes; "eggs three, often only two" (Gibbs); an elegant bird. 
304 (985-(147). Sylvamia pusilla (Wils.). Wilson's Watbler; Greex BuachCapped Yellow Warbler.

"Tolerably common in Northern Indiana" (Butler's Birds of Indiana); "exceedingly abundant migrant at Mackinac Island and in spring in Kent County" (S. E. White); E. E. Brewster writes me that it is common at Iron Mountain; "often common migrant in Monroe County" (Jerome Trombley); "common migrant in "Nichigan" (Dr. M. Gibbs); I have never taken this bird about the college.

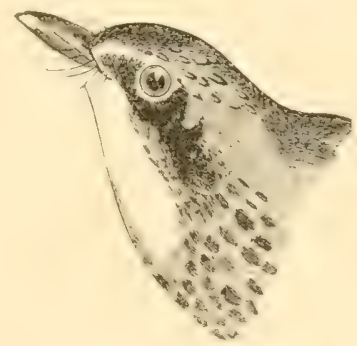

Canadian Flycatching Warbler, natural size.

305-68(;-(149). Sylvania canadensis (Linn.). * Canadran WARBler; Cavadiax Flicatching Warbler.

Not rare; migrant; April and May and August and September; "rather common in Kalamazoo County" (Dr. M. Gibbs); Lenawee County" (A. H. Boies); common migrant in Monroe County" (Jerome Trombley); "Iron Mountain" (E. E. Brewster); "Keweenaw Point" (Kneeland); "common summer resident at Maekinac Island" (S. E. White); probably breeds in Northern Peninsula; nests in June on the ground; egge four or five.

Genus SETOPHAGA Swains.

306-657-(152). Setophaga ruticilla (Linn.). * Alrerican Redstart.

Very common; throughout the entire State; May to August; "Mackinac Island" (S. E. White); "rare at Iron Mountain" (E. E. Brewster); breeds; nests in June in small trees, usually twelve to twenty feet from the ground, rarely forty feet; "nests at Manchester, neatly woven in vertical crotch of shrubs about twelve feet high" (L. W. Watkins); nests usually found in thick woods or dense swamps; "breeds abundantly at Ann Arbor" (Dr. J. B. Steere). Dr. Atkins gives dates of its arrival for 26 year's in 0. and $\mathrm{O}$., Vol. VIII, p. 31. 
Fanily motacillide. Wagtails and Pipits.

Small birds; insectivorous; often in flocks.

GENUS ANTHUS BEOHST.

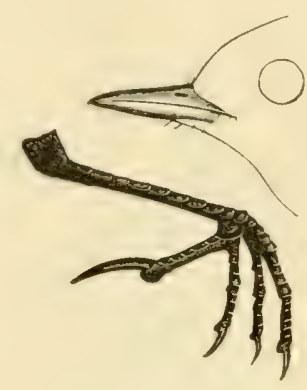

Titlark, natural size.

307 697-(89). Anthus pensilvanicus (Lath.). *Anerican PIPIT; AMericin Titlark; Wag-tail; Brown Lark; Pipit.

Common; throughout the state; in flocks; April and May, and Sept. to Nov., occasional in Dec. and Jan.; migrant; “" common at Iron Mountain in autumn and probably in spring" (E. E. Brewster); "Keweenaw Point" (Kneeland); "winter sojourner" (A. H. Boies). Taken_here by L. W. Watkins, May 10, 1893.

Family troglodytidæ. Wrens; Thrashers, etc.

Insectivorous birds; often sweet singers.

Subfamily Mimina. Thrashers.

GENUS MIMUS BoIES.

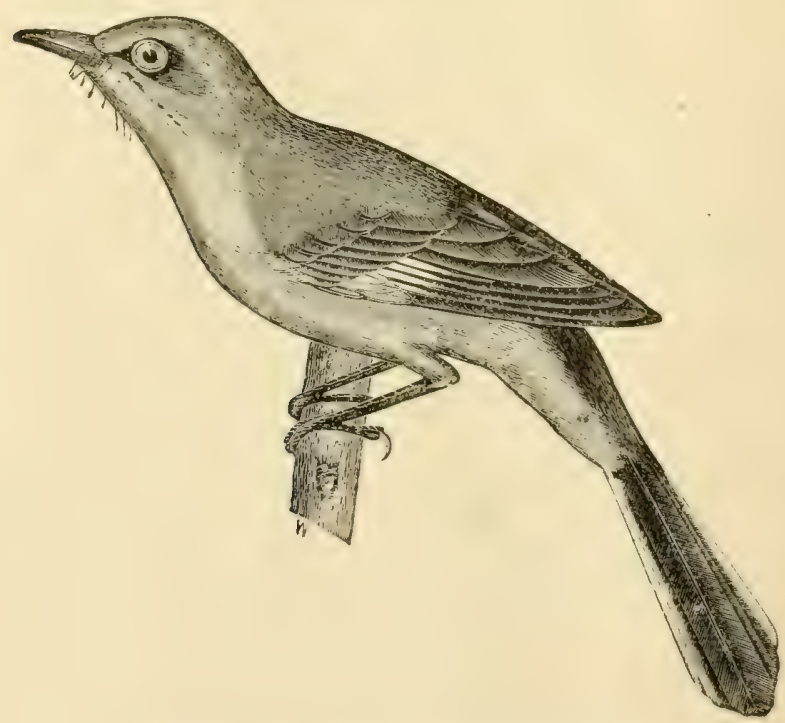

Mocking Bird, about two-thirds natural size. 
308-703-(15). Mimus polyglottos (Linn.). * Mockivg Bird.

Possibly a rare accidental straggler from the south. One reported by E. L. Moseley. This species is included in the manuscript list of the Birds about Detroit, by the late Rev. Chs. Fox.

Gexus Galeuscoptes Cab.

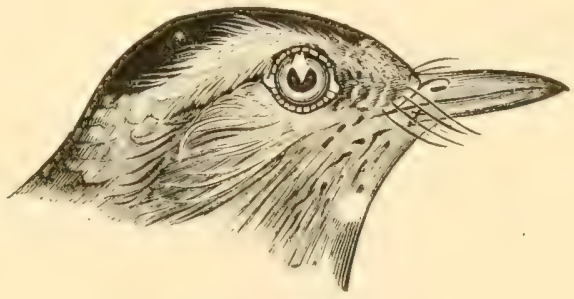

Cat-bird, natural size.

309-704-(16). Galeoscoptes carolinensis (Linn.). * C

Very common; throughout the state; usually in woodlands, though here at the college where we protect the birds, they even breed freely on the campus; April and May to Sept.; "Mackinac Island" (S. E. White); "rare at Iron Mountain" (E. E. Brewster); breeds; nests in shrubs; eggs four, rarely five, deep green; song pleasing and varied.

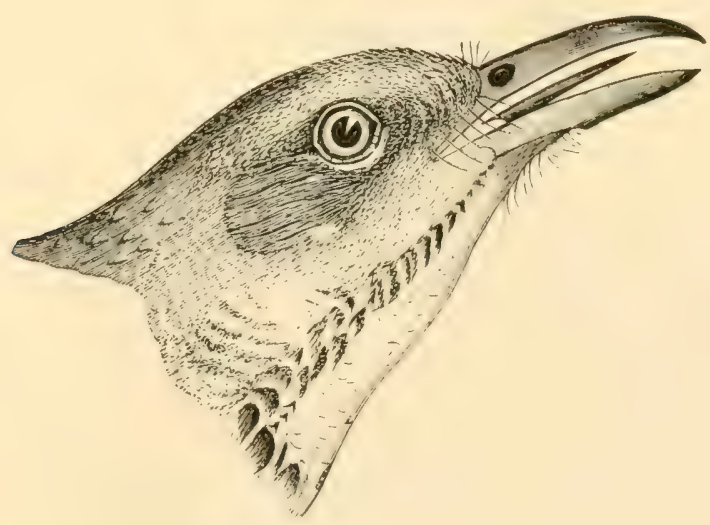

Brown Thrush, nataral size.

310-705-(17). Harporlynchus rufus (Limn.). *Browx Throsh; Big Browe Wren; Brown Thrasher; Brown Mocking Bird.

Very common, especially south; April to Sept.; "Grand Traverse County" (M. L. Leach); "April 28, 1891, at Grand Rapids" (E. B. Boies); "Mackinac Island" (S. E. White); "not seen in Upper Peninsula" (A. H. Boies); "very common at Iron Mountain, where with many other song birds they suffer seriously at the hands of the Italians, who kill them for stews" (E. E. Brewster); not shy; strong singers; "song wonderfully rich, melodious and varied" (L. S. Foster); breeds; nests in bushes, ocea- 
sionally on the ground; nest rude, coarse and bulky; eggs three to five, dirty white, specked with brown; food small fruits and insects; "Forbes found 23 per cent of food which he examined to be canker worms" (report State Horticultural Society, 1891, p. 201); like the Robin, this bird often returns to the same place year after year.

Semanily TROGLODYTIN.E. Wrexis.

(GENUS THRYOTHORUS VIEILL.

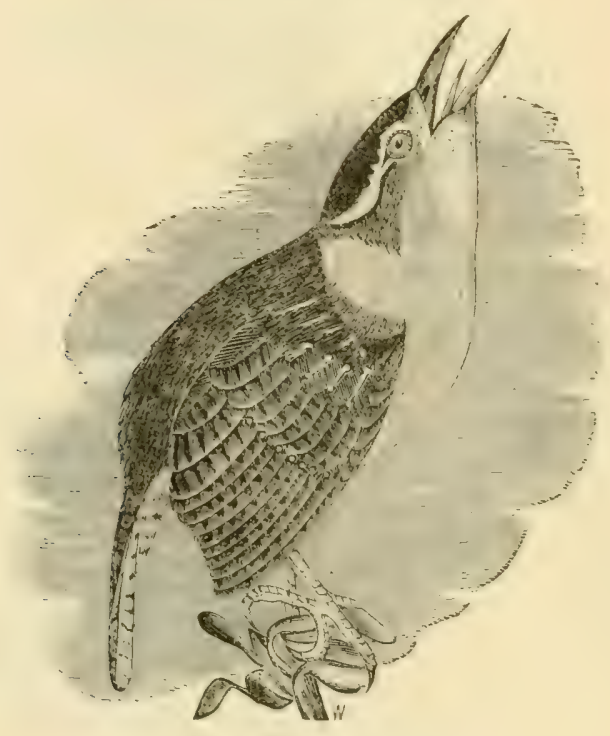

Carolna Wren.

\section{1-718-(68). Thryothorus ludovicianus (Lach.). Carolina Wren.}

Rare summer resident in southern part of the State; "Lenawee County" (A. H. Bo:es); Jerome Trombley finds it a rare summer resident in Monroe County, where he took a nest in 1892, beneath the roots of a fallen tree, with six eggs in it; "northern counties of Indiana" (Butler's Birds of Indiana). Said to breed at nearly all seasons. We have never seen it here. J. B. Purdy says it does not breed at Plymouth.

312-719-(71). Thryothorus bewickii (Aud.). BEwICk's Wren.

"Very rare, in spring" (Dr. M. Gibbs); very rare; "summer resident in Monroe County, where it has nested three years in a bird box, identification certain" (Jerome Trombley); "rare, but several taken in Kalamazoo County" (Dr. M. Gibbs); we have never taken this here, and J. B. Purdy says the same of Plymouth.

\section{Genus TROGLODYTES Vieill.}

313-721-(74). Troglodytes aëdon (Vieill.). House Wren.

Very common in some localities; April to October; "abundant at Grand Rapids" (E. B. Boies); "becoming rare at Plymouth" (J. B. Purdy); "not rare at Ann Arbor" (Dr. J. B. Steere); " not seen in Upper Peninsula " (A. H. Boies); "Mackinac Island" (S. E. White); " common at Iron Mountain" (E. E. Brewster); breeds; nests in holes in 
trees, stumps, in niches under porches, boxes, etc., in June, occasionaliy second time in August; eggs four to ten, white, thickly specked with reddish brown. This bird is very rare at Lansing, especially since the advent of the English Sparrow, but "very" common at "Traverse City" (L. W. Watkins; "this bird leaves the vicinity of our dwellings after breeding" (L.S. Foster). This little. Wren nested in my whirling horsetether box, and repaired its nest time after time, as it would be destroyed by the turning of the box-there were six eggs.

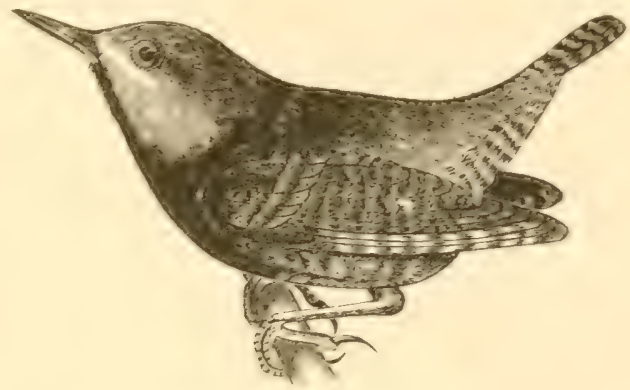

Winter Wren. slightly reduced.

314 720-(76). 'Troglodytes hiemalis Vieill. *WINTER WREx.

Common migrant; "transient in Monroe County, seen oftener in spring than in fall" (Jerome 'Trombley); "migrant at Plymouth" (J. B. Purdy); "very common in spring, summer and fall, and occasionally in late winter, breeds" (Dr. M. Gibbs): reported by S. E. White at Grand Rapids, June 11, 1891; "rare at Ann Arbor " (Dr. J. B. Steere); it is very rare at Lansing; "Kent County, where it breeds, and Mackinac Island" (S. E. White); "Keweenaw Point" (Kneeland); rather shy; " breeds in Upper Peninsula" (Prof. Ludwig Kumlein); E. W. Durfee took a nest near Grand Rapicls; "nesting habits much as in last species" (Davie's Nests and Eggs on North American Birds, p. 407); though it may nest in brush-piles, etc.; nest lined with feathers; eggs four to nine, white, minutely specked with brown; feeds on insects and insects' eggs; "song loud and hearty, scolds vigorously at intrusion" (E. L. Mloseley).

GENUS CISTOTHORUS (AB.

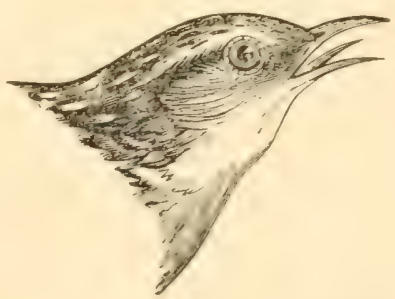

Short-billed Misr-h Wren, uatoral size.

315-724-(S1). Cistothorus stellaris (Lieht.). * Short-Billed Marsh Wrex.

Rather common; summer; "rare at Ann Arbor" (Dr. J. B. Steere); "Lenawee County" (A. H. Boies); "common in marshes at the west end of Lake Erie" 
(Jerome Trombley); breeds; nests in July; nesting habits as in next species, except that it nests in clear places and in moist meadows, not over water (R. H. Wolcott); and the nest is formed of fresh reeds and flags and beautifully lined with cotton like down; E. W. Durfee finds nests not uncommon in Wayne County; eggs six to nine, white. Mr. E. W. Durfee states that these, like the next species, make two or three duplicate nests.

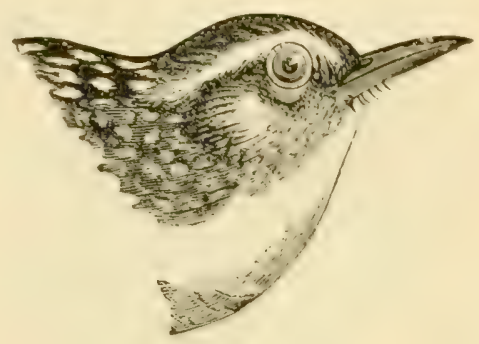

Long-billed Marsh Wren, natural slze.

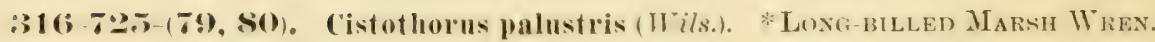

Rather common in summer; "rare at Ann Arbor" (Dr. J. B. Steere); "St. Joseph County" (1. H. Boies); "abundant in the marshes at the west end of Lake Erie" . Herome 'Trombley); "nests found in Wayne County" (F. F. Durfee); breeds; nests in whonies, near the ground. in marshes, in spherical nests of coarse grass, etc., "fastened to old flags two or three feet above the water or mud" (E. L. Moseley), the opening on the side; eggs five to ten, very small, dark chocolate brown, rarely almost white; "while the female is sitting the male partially builds one or more nests" (Dr. A. K. Fisher); Dr. W. C. Brownell writes me that there are sometimes eight of these duplieate and unlined nests.

\section{Famly CeRThIIDA. Creepers.}

Small, narrow-billed birds; seen creeping up tree trunk; food insects and insects' argst.

GENUS CERTHIA LINX.

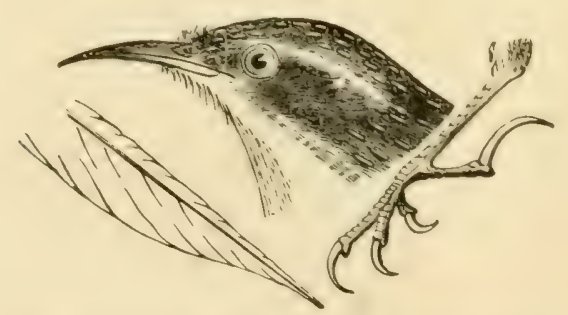

Head, foot and tail-feather of Certhia, natural size.

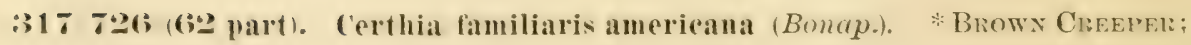
Anericax Creeper.

Rather common; throughout the entire state; all seasons; "does not breed at Plymouth" (J. B. Purdy); "rather rare at Ann Arbor" (Dr. J. B. Steere); "formerly nested 
in Monroe County, now only a migrant, found a nest behind loose bark of a tree in 1865" (Jerome Trombley); "rather common in Kent County in summer and at Mackinac Island" (S. E. White); "common at Iron Mountain" (E. E. Brewster); "common in November at Au Sable" (N. A. Eddy, O. and O., Vol. IX, p. 91); breeds; nests, between loosened bark and tree" (Dr. A. K. Fisher); "under bark of stub thirty feet high in Ottawa County" (Dr. M. Gibbs); see Davie's Nests and Eggs of North American Birds, p. 410; in May; eggs five to eight, white, specked with brown. This bird climbs spirally up tree trunks.

\section{Family PaRide. Nuthatches and Tits.}

Food insects and insects' eggs; they creep up tree trunks and along limbs much as do the Sapsuckers and Creepers, except they usually go downwards head foremost as they hunt for their food. They are exceedingly valuable birds.

\section{Subfanily SiTTINA. Nuthatohfs.}

GeNus SITTA Lixy.

318-727-(57). Sitta carolinensis Lath. *White-Breasted Nuthatch; Tontit; White-belited Nuthatch.

Common; throughout the entire state; every month of the year"; "common at Ann Arbor" (Dr. J. B. Steere); "Au Sable" (N. A. Eddly); "never seen at Iron Mountain, Upper Peninsula" (E. E. Brewster); "Mackinac Island" (S. E. White); breeds; nests in April; nests usually made in ready formed holes in trees from ten to fifty feet from the ground; eggs four to eight, rarely nine or ten, white to roseate, specked with brown; this bird is often seen creeping down trees head foremost; will place acorns containing weevil grubs in some cavity in bark to hold them secure and then pick out the relicate tit-bit.

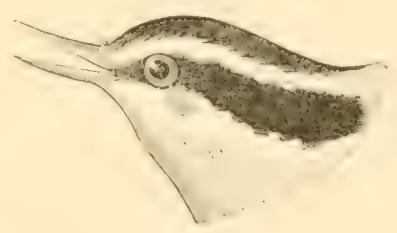

Red-bellied Nuthatch, natural size.

319-728-(59). Sitta canadensis Limn. Ked-breasted Nuthitch; Red-betuted Nuthatch: Canada Nuthatoh.

Rather rare; more common north; "rare fall and spring migrant in Monroe County, none remaining to breed" (Jerome Trombley); "rare in Wayne County" (B. H. Swales); "common during migration" (F. L. Moseley); "rarely seen at Ann Arbor" (Dr. J. B. Steere); "does not breed at Plymouth" (J. B. Purdy); "very common at Iron Mountain in the Upper Peninsula" (E. E. Brewster); "Keweenaw Point" (Kneeland); "abundant at Mackinac Island, and occurs in winter in rast flocks, in Upper Peninsula, in Iron County" (S. E. White); "breeds" (Dr. M. Gibbs); nests and eggs as in the preceding species except that the eggs are slightly smaller; we find this more rare here than the preceding species. 


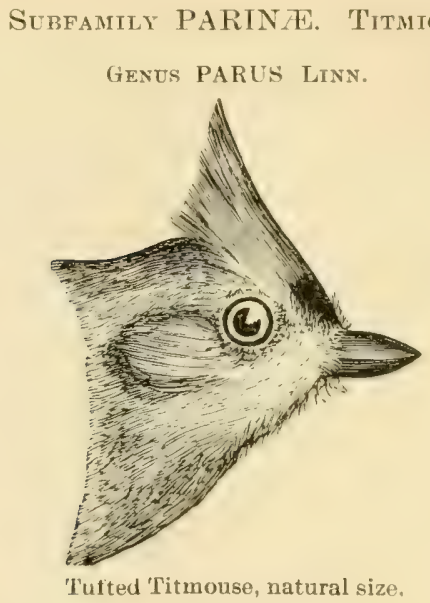

320-731-(40). Parus bicolor (Linn.). *Tufted Titmouse; Sugar Bimd; BlackFronted 'I'ITMOUSE.

Common in more southern parts of the state; winter; occasional in April and May and Sept.; "is regular winter resident at Ann Arbor" (Dr. J. B. Steere); "common in Lenawee and Hillsdale Counties" (A. H. Boies); "every year in Monroe County often until late May" (Jerome Trombley); "Benjamin Syke found this abundantly in Van Buren County one year" (Dr. M. Gibbs); "only taken once at Plymouth" (J. B. Purdy); "rarely found north of 40 degrees" $(\mathrm{H}$. Nehrling); "summer resident in northern counties of Indiana" (Butler); Dr. Atkins reports taking this in April and May at Locke; we have taken it at this place; two specimens taken by Stewart $\mathbf{E}$. White in Kent County in June, 1891; these valuable birds eat a great many leaf rollers and other insects during the winter season; J. E. Nichols, of Lansing, has this bird in his collection taken in Sept., 1881; he has often taken it about Lansing in fall and spring.

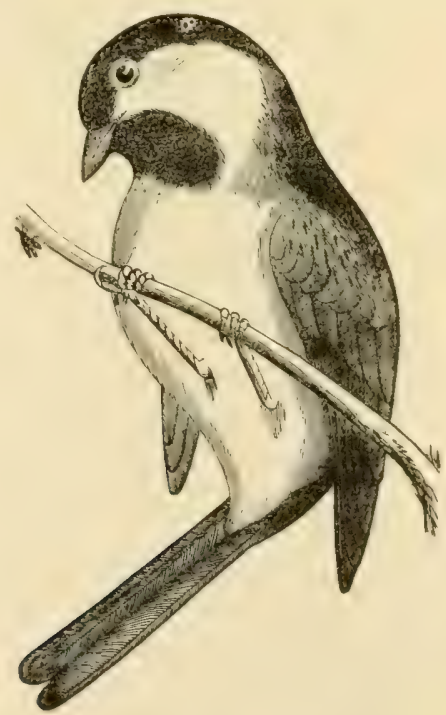

Black-capped Chickadee, rednced. 
321-735-(44). Parus atricapillus Linn. *Chichadee; Buach-capped Chichadee.

Very common; throughout the entire state; every month of the year; "very common at Ann Arbor" (Dr. J. B. Steere); "resident in Monroe County, but much more common in winter" (Jerome Trombley); "Grand Traverse County" (M. L. Leach); "Mackinac Island" (S. E. White); "Keweenaw Point" (Kneeland); "very common at Iron Mountain" (E. E. Brewster) common at Bay City in the spring, 1884 (N. A. Eddy in $\mathrm{O}$. and O.. Vol. IX, p. 41); breeds; nests in a hole in a tree or stump; "breeds year after year in same nest, where they may roost in winter" (Dr. W. C. Brownell); "breeds at Traverse City" (L. W. Watkins); "have found full sets of egrgs in April " (Dr. W. C. Brownell); eggs five or six, eight taken by Gilbert White in Kent County, May, 1892. ten young found in nest by F. M. Falconer, white specked with brown; "this bird is very familiar, may alight on a person" (E. L. Moseley, Forest and Stream, Sept., 1886); Dr. Atkms reported seeing them eat tent caterpillars extensively.

32-740-(49). Parus hudsonicus Forst. Hudsonian Chickadee.

Rare; "Northern Michigan" (Dr. A. K. Fisher); "a rare winter resident of Northern Michigan" (H. Nehrling); "Keweenaw Point" (Kneeland); in Cabot's list of Birds of Upper Peninsula.

Fanily Sylvitde. Warblers; Kinglets; Gnatcatchers.

Small, beautiful, insectirorous birds; feed largely on insects and insects' eggs.

Setsfantio RegUliNe. Kinglets.

genus Regulus Cur.

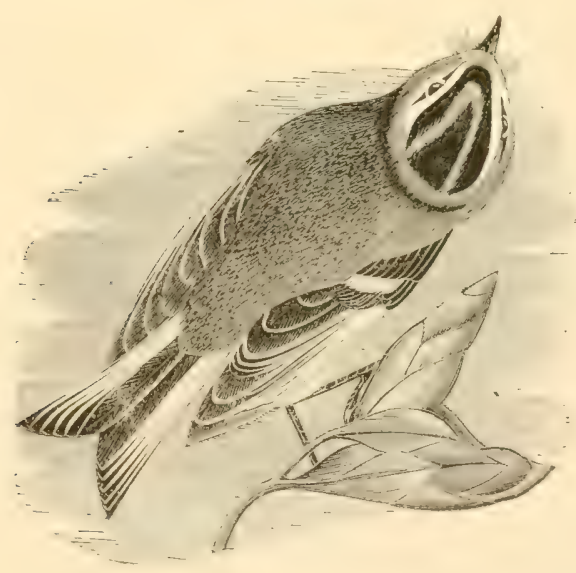

Golden-crowned Kinglet.

323-748-(34). Regulus satrapa Licht. *Golden-crownen Kinglet; Goldexcrowned Wrex; Goldex-crested Kinglet.

Common; migrant; Mar. to May and Oet. and Nov.; occasionally a winter resident; "more common at Ann Arbor than the next species" (Dr. J. B. Steere); "more timid 
and retiring than the next species and comes and goes in flocks; probably does not breed in Southern Michigan" (A. H. Boies); "saw them at Plymouth, but they do not breed here" (J. B. Purdy); "Grand Rapids, April 14, 1891" (E. B. Boies); "common in winter in Wayne County" (B. H. Swales); "abundant migrant in Kent County" (S. E. White); found in woods; "common at Iron Mountain" (E. E. Brewster); included in Cabot's Birds of Lake Superior; found breeding at Ontonagon by Prof. Ludwig Kumlein; "breeds abundantly at Mackinac Island in July" (S. E. White); "eggrs four to nine occasionally ten" (Prof. A. W. Butler); "nine" (E. E. Brewster); cream color, or creamy white, specked with brown.

324-749-(33). Regulus calendula (Linn.). * Ruby-crowned Kinglet.

Rather common; throughout the state; migrant; April and May, and Oet. and Nov.; "rare at Ann Arbor" (Dr. J. B. Steere); "Dewitt" (Dr. G. W. Topping); "common at Iron Mountain" (E. E. Brewster); breeds in the Northern Peninsula; "nests with five young at Mackinac Island. July 26. 1890" (S. E. White); "breeds at Linse" (Prof. Ludwig Kumlein); "nests semipensile in trees" (Coues' North American Birds); "eggs five to nine, dull whitish, or pale buff, faintly spotted with light brown, chiefly at the larger end" (Davie); "often found in flocks with the preceding species" (Prof. J.W.Simmons); this and the preceding species are two of our most elegant birds. This species is not shy.

Subamily POLIOPTILINe. Gatatcatehers.

GeNus POLIOPTila sclat.

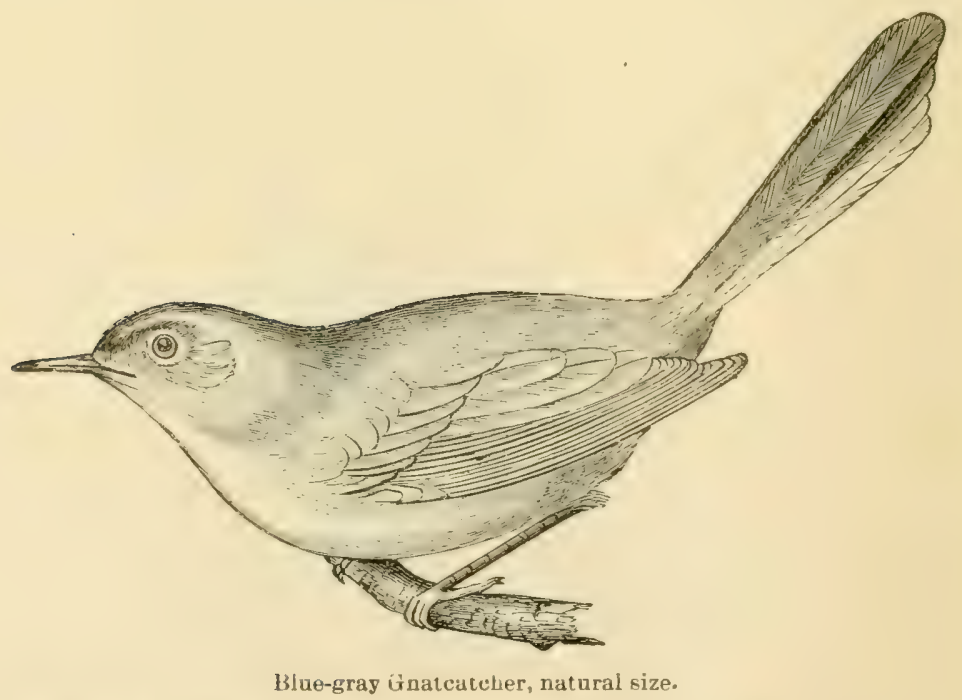

325-751-(36). Polioptila cerulea (Linn.). *Blue-Gray Gratcatcher.

Very common; throughout Southern Michigan; A pril to Sept.; "very common at Ann Arbor" (Dr. J. B. Steere); we find it common at this place; S. E. White reports it rare at Mackinac Island and says it is found in the Northern Peninsula; breeds; nests in trees in May; nest elegant, softly lined and covered outside with lichens; often secures material for nest from nests of other birds: eggs four to seven, white, specked with brown; habits much like those of Creepers and Nuthatches. 
Family TURdid E. Thrushes; Blue Birds, etc.

Food principally insects, often fruit; usually sweet singers.

Scbeamily TURDINA. Thrushes.

Genus TURDUS LINN.

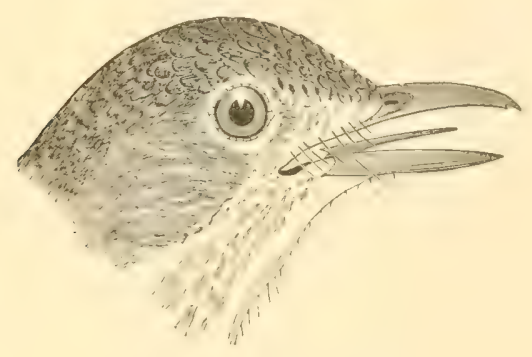

Wood Thrush, natural size.

326-755-(6). Turdus mustelinus (Gmel.). *Wood Thrush; Sont T'hrush.

Not rare; throughout the state; April and May to October; numbers decreasing as the thickets are cleared up; "occurs at Mackinac Inland" (S. E. White); "Keweenaw Point" (Kneeland); breeds at least in Southern Peninsula; nests in May and June in trees or shrubs, "in orchards" (Dr. A. K. Fisher); I have found the nests more commonly in damp, thick woods, and generally on low beech limbs; "nests at Traverse City" (L. W. Watkins); eggs like those of the Robin, except a trifle smaller, two to five; "this bird is shy during molt" (Dr. A. K. Fisher); and is usually seen in dense woodlands and thickets; the food habits of the Wood Thrush are much the same as those of the Robin.

327-756-(7). Turdus fuscescens Steph. *Wilson's Thrush; Veery; Tawny Thrush.

Common at least in southern part of the state; throughout the Lower Peninsula; April to Sept.; usually in swampy woods; "Keweenaw Point" (Kneeland); "occurs at Mackinac Island" (S. E. White): Mr. White informs me that it breeds in Kent County; breeds; "have seen them very abundant in Wayne County where they breed abundantly" (Dr. W. C. Brownell); nests on ground, occasionally in low shrubs or clumps of bushes, in May or June; eggs blue, four, occasionally five.

328-757-(12). Turdus alicix Buird. *Gray-CheEked Thrush.

One reported from Michigan in the museum of the Kent Scientific Institute by E. L. Mosely; taken in Kent County by S. E. White; "one taken at Locke, May 10, 1883" (Dr. H. A. Atkins); " this bird is recorded from Kalamazoo County by F. H. Chapin and from Kent County by Mr. Chas. W. Gunn" (Dr. M. Gibbs).

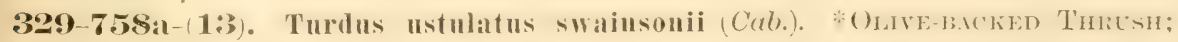
Swainson's Thrush; Swamp Robin.

Common; throughout the Southern Peninsula if not the entire state; May to Oct; E. B. Boies reports a large flock at Grand Rapids April 16 and 18. 1891; (Wats not this the 
Hermit Thrush?) "rare in Wayne County" (B. H. Swales); "Lenawee County" (A. H. Boies); "rare and transient in Monroe County" (Jerome Trombley); "occurs at Mackinac Island" (S. E. White): "Keweenaw Point" (Kneeland): breeds north; we have never found it nesting here; J. B. Purdy of Plymouth, has never seen or found a nest at that place; Dr. M. Gihbs reports taking nests and eggs in Kialamazoo County; (Is not this a mistake?) nests in low shrubs in June; nest compact with no mud; eggs four, bluish green, and peeuliar in being specked with varying shades of brown; this bird is a sweet and almost continuous singer. Dr. M. Gibbs gives an excellent deseription of this bird and its nesting and migration in O. and O., Vol. X, 1885, p. 26.

3:30-759b-(10). Turdus aonalaschkir pallasii $(C u b$.$) . *Hermit Thresh; Cathe-$ dral Bird; Rufus-tailed Thrush; Ground Swamp Robin; Swamp Angel.

April and May to Oct.; "Monroe County, common, transient" (Jerome Trombley); "occurs at Mackinac Island" (S. E. White): "Upper Peninsula" (H. Nehrling); "common at Iron Mountain" (E. E. Brewster); breeds north; nests taken in Montcalm County, by Dr. Gibbs, June 23, 1882; also " in Ottawa County, May 15, 1879, by W. A. Gunn" (Dr. M. Gibbs); nests in June, usually on the ground, "in July at Mackinac Island" (S. E. White), rarely in low shrubs; the nest loosely constructed and without mud; eggs three or four. light blue. immaculate. For interesting account of the habits of this bird, see article by Dr. M. Gibbs in O. and O., Vol. X, p. 27.

GeNus MERULA LEACH.

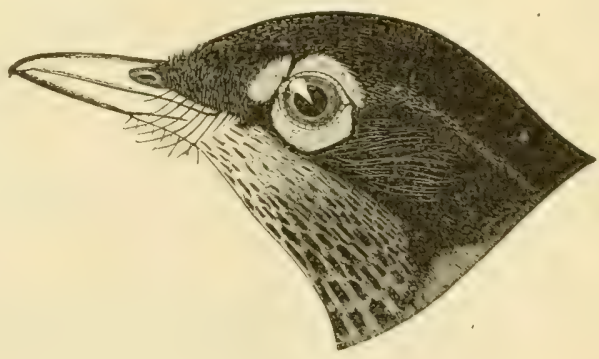

Robin, natural size.

331-761-(1). Merula migratoria (Limn.). * A merican Robin; Robin.

Very common; throughout the entire state; "very common at Iron Mountain" (E. E. Brewster); March to October; rarely throughout the winter: "Grand Rapids Feb. 28, 1892 " (E. B. Boies); retires in winter to protected localities and so is not so often seen; "Traverse City" (Dr. M. L. Leach); "occurs at Mackinac Island" (S. E. White); "Keweenaw Point" (Kneeland); occasionally albinos; I knew an albino female, presumably the same bird, to nest two successive summers in the same nest; breeds; of ten two brooded; "always double brooded if undisturbed" (Dr. M. Gibbs); nests on fences, in trees, on ledges under eaves, in old nests, rarely of other birds, "in buildings" ( $O$. and O., Vol. XIV, 1889, p. 43) etc.; eggs three to five, greenish blue, "rarely sprinkled with brown" (A. W. Butler); eats myriads of insects. mostly noxious species, angle worms and fruit, cherries, berries and grapes; 40 per cent of the food of birds examined by Prof. Forbes (report Michigan Horticultural Society, 1851, p. 204) was found to be canker worms. 
Genus SiAlia Swains.

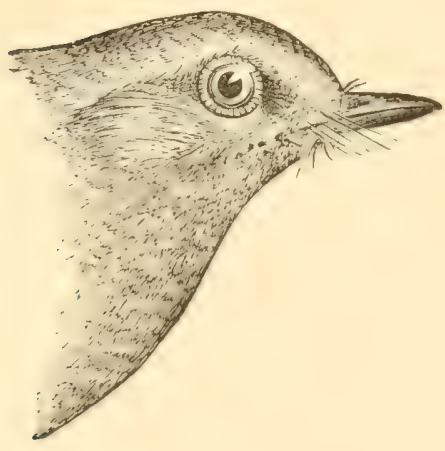

Blue Bird, natural size.

332-766-(27). Sialia sialis (Linn.). *BLuE Burd.

Common; throughout the entire state; less common than formerly; driven away by English Sparrows; Feb. or March to Nov,; "one of our earliest birds to arrive in the spring, Grand Rapids Feb. 26, 1891" (E. B. Boies); "Grand Traverse County" (M. L. Leach); "occurs at Mackinac Island" (S. E. White); "Keweenaw Point" (Kneeland); "very common at Iron Mountain" (E. E. Brewster); breeds; "double or triple brooded" (Prof. J. W. Simmons); nests in hollow trees, "either in holes which they excavate in rotten trees, or which other birds have excavated" (J. E. Nichols), in boxes, etc.; eggs four to six, light blue, rarely pure white; a very beautiful and valuable bird. 



\section{INDEX.}

\begin{tabular}{|c|c|c|c|}
\hline & Page. & & age. \\
\hline Acadian Flycatcher... & $8: 3$ & American Kawk Owl...... & 71 \\
\hline Acadian Owl & 69 & American Herring Gull ............ & 28 \\
\hline Acanthis & 93 & American Long-eared Owl.......... & 68 \\
\hline hornemanii exilipes & 5 & 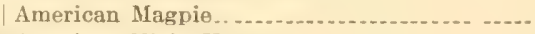 & 85 \\
\hline linaria... & 93 & American Niglit Heron..... & 44 \\
\hline linaria rostrata & 94 & American Osprey .............. & 66 \\
\hline Accipiter & 62 & American Pipit & 120 \\
\hline atricapillus & 63 & American Pochard Duck & 35 \\
\hline cooperi............. & 62 & American Redstart & 119 \\
\hline velox... & 62 & 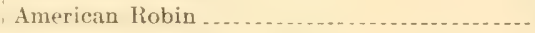 & 130 \\
\hline Accipitring ............ & 61 & American Rough-legged Hawk. & 61 \\
\hline Actitis . . . . . . & 53 & American Scaup Dack .......... & 36 \\
\hline macularia. & 53 & American Scuter. & 38 \\
\hline Fchmophorus ......... & 34 & American Snipe ........... & 49 \\
\hline occ & 24 & American Sparrow Hawk.... & 66 \\
\hline Egialitis & 55 & American Swan & 40 \\
\hline meloda & 55 & American Three-toed Woodpecker & 75 \\
\hline meloda circumcincta & 56 & American Titlark. & 120 \\
\hline semipalmata & 55 & American White-fronted Goose & 39 \\
\hline vocifera & 5. & American White Pelican & 31 \\
\hline gelaius & 48 & American Widgeon & 33 \\
\hline phœniceus ..... & 88 & American Woodcock & 48 \\
\hline Aix. & 35 & Ammodramus & 96 \\
\hline sponsa & 35 & caudacntas nelsoni & 97 \\
\hline Alaudidæ & 84 & henslowii & 97 \\
\hline Alca. & 26 & leconteii ................... & 5,97 \\
\hline & 26 & sandwichensis savanna. ........... & 96 \\
\hline Alcedinidø... & 73 & savannarum passerinus & 97 \\
\hline Alcidre & 26 & 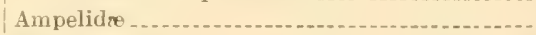 & 105 \\
\hline Alcyones . . . . . . . . & 73 & Ampelina ............... & 105 \\
\hline American Avocet & 48 & Ampelis .................... & 105 \\
\hline American Barn Owl & 67 & cedrorum & 106 \\
\hline American Bittern & 41 & garrulus .............. & 105 \\
\hline American Black Scoter... & 38 & Alcidø & 26 \\
\hline American Coot .............. & 46 & Alle & 27 \\
\hline American Creeper ........ & 124 & An act for the Protection of Birds & 6 \\
\hline American Crossbill ........ & 93 & Anas & 32 \\
\hline American Dunlin ........... & 50 & americana & 33 \\
\hline American Eider Duck... & 38 & boschas.......... & 32 \\
\hline American Golden-eye...... & 36 & carolinensis .... & 33 \\
\hline American Golden Plover......... & 55 & discors .......... & 33 \\
\hline American Goldfinch & 91 & obscura.... & 33 \\
\hline wk & 63 & strepera & 33 \\
\hline American Green Sandpiper. & 52 & Anatidro........ & 81 \\
\hline
\end{tabular}


Page.

Anatinge

Ancient Murrelet

Anhinga Anhinga.

Anser -

albifrons gambeli

Anseres

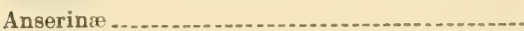

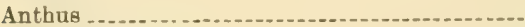
pensilvanicns

Antrostomus . vociferas

Aphrizida

Aquila. chrysaētos

Archibuteo lagopus sancti-johannis.

Arctic Tern

Arctic Three-toed Woodpecker

Ardea

egretta

herodias

tricolor ruficollis

virescens

Ardeidæ

Ardeinge

Arenaria

interpres

Arenariinø .

Asio

accipitrinus

wilsonianus

Auks

Aathorities, list of

Avocet

American

Avocets

Aythya

affinis

americana.

collaris

marila nearctica

vallisneria

Baird's Sandpiper

Bald Eagle

Baldpate

Baltimore Oriole

Banded-backed Three-toed Woodpecker.

Bank Swallow

Barn Owl

Barn Swallow

Barred Owl

Barrel Maker

Barrow's Golden Eye

Bartramia

longicand

Bartramian Sandpiper

Bartramian Tattler

Bay-brested Warbler

Bay-winged Bunting

Bee Martin

Belted Kingfisher.

Belted Piping Plover
Page.

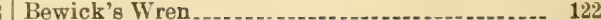

26 Bibliography .................................. 12

5 Bird, Blue__.. 131

39 Butcher ............ 107

39 Cat ........................................... 121

31 Cedar 106

38 Cherry ....................................... 106

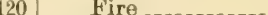

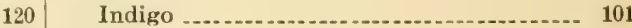

77 Lettuce

78 Snow $\ldots$

56 Summer Red ............................... 102

65 Thistle 9

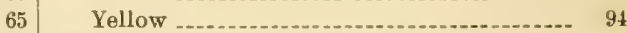

64 Birds, an act for the protection of ........... 6

64 Birds of prey 60

29 Bittern ........ 41

42 Least ......................................... 42

Bitterns........ 41

5 Black and White Creeper....................... 110

43 Black and White Warbler .................... 110

43 Black and Yellow Warbler ..................... 113

43 Black-backed Three-towed Woodpecker........ 75

43 Black-bellied Plover ........ 54

11 Black-bellied Sandpiper......................... 50

12 Black-billed Cuckoo

6 Blackbird .

56 Bronzed Crow

Common

('row -.... . -

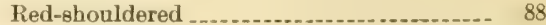

Red-winged .................................... 88

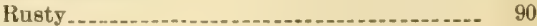

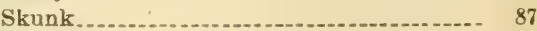

Swamp .....

Yellow-headed

Blackbirds .

Blackburnian Warbler...................... 114

Black-capped Chickadee............._._._._. 127

Black Guillemot ............................. 26

36 Black-headed Gall

50 Black-shouldered Kite

65 Black Tern 30

33 Black-throated Blue Warbler .................. 112

89 Black-throated Bunting 101

75 Black-throated Diver.......................... 26

104 Black-throated Green Warbler................. 115

67 Black-throated Loon ............................. 26

103 Black-throated Murrelet..................... 26

68 Black-winged Redbird 102

41 Black Woodpecker ............................ 76

37 Blue-backed Swallow

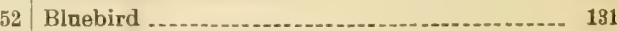

52 Blue Golden-winged Warbler

52 Blue Goose ............. 39

52 Blue-gray Gnatcatcher...................... 128

114 Blue-headed Greenlet ........ 109

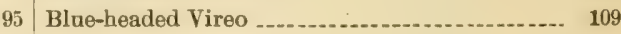

81 Blue Jay

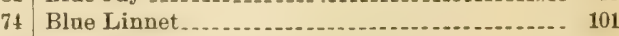

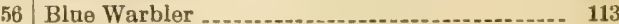


Blue-winged Teal

Blue-winged Warbler

Blue-winged Yellow Warbler

Blue Yellow-backed Warbler.

Bob Lincoln

Bobolink .

Bob White.

Bohemian Waxwing

Bonaparte's Gull

Bonaparte's Sandpiper

Bonasa. umbellus.

Books ...

Botaurinæ

Botaurus

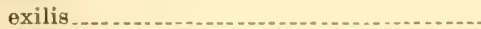

lentiginosus

Brant

Branta

bernicla

canadensis

canadensis hatchinsii

canadensis minima

canadensis occidentalis

Bridge Bird

Broad-winged Hawk

Bronzed Crow Blackbird

Bronzed Grackle.

Brotherly-love Greenlet

Brotherly-love Vireo

Brown Creeper.

Brown Lark.

Brown Thrasher

Brown Thrush

Bubo

virginianus

virginianus subarcticus

Bubonide

Buff-breasted Sandpiper

Buffle-head

Bull Bat.

Bunting .

Bay-winged

Black-throated

Cow

Henslow' 8 .

Indigo

Snow

Towhee

Varied.

Butcher Bird.

Buteo

borealis

latissimus.

lineatus

swainsoni

Butter-ball

Butter-bird

Buzzard

Red-shouldered

Red-tailed.

Turkey

Cackling Goose

Calcarius

lapponicus
Page.

33 Calcarius, pictus

$\$ 11$ Calidris .................................... 51

111 arenaria....... 51

112 Camptolaimus .............................. 5

87 labradorius 5

87 Canada Goose ............................... 40

57 Canala Grouse

10.5 C'anada Jay ................................. $86^{\circ}$

28 | Canada Nuthatch .......................... 125

50 Canadian Flycatching Warbler.............. 119

58 Canadian Warbler ......................... 119

58 | Canvas-back Duck

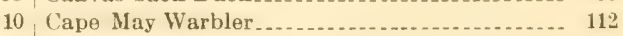

41 Caprimulgi .................................. 77

41 Caprimulgide

42 Cardinal _............... 100

41 Cardinal Grosbeak.......................... 100

40 | Cardinalis ................ 100

39 cardinalis 100

40 Carolina Grebe............................. 25

$40 \mid$ Carolina Paroquet...................... 72

40 Carolina Wren............ 122

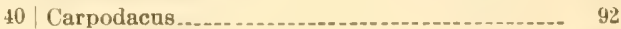

40 purpureus

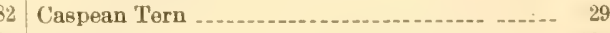

64 Cat Bird ........ 121

90 Cathartes.............. 60

90 aura .............. 60

108 Cathartidæ

108 Cathedral Bird............................. 130

124 Cayenne Tern 29

$120 \mid$ Cedarbird ............. 106

121 Ceophloeus ...................................... 76

121 pileatus

70 Cepphus

70 grylle........

1 Certhia .............. 124

familiaris americana..................... 124

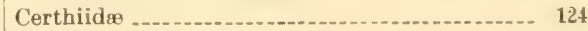

7 Cerulean Warbler................................... 113

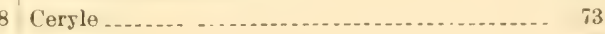
alcyon

Chatura.......................................... 79 pelagica ................... 79

Chrturinæ .... 79

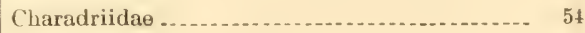

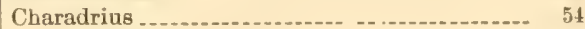

dominicus.......................... 55 squatarola

Charitonetta ..................................... 37 albeola ....................................... 37

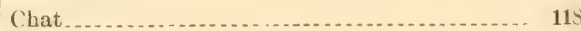

Yellow-breasted ......................... 115

Chelidon 103 erythrogaster........... 103

Chen - 38

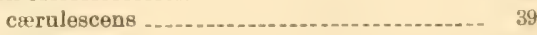

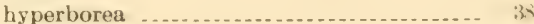
hyperborea, nivalis .......................... $\quad 39$

Cherry Bird ................................... 100

Chestnnt-sided Warbler. ........... . . . . . . . . 113

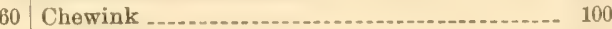

Chickadee....

Black-capped ............................ 127

Hudsonian ................................... 127

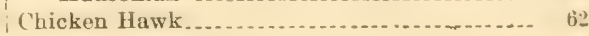


Chimney Swallow

Chimney Swift

Chippie.

Chipping Sparrow

Chondesetes. grammacus

Chordeiles . virginianus

Circus hudsonius

Cistothorus palustris stellaris

Clamatores

Clangula byemalis .........................................

Clay-colored sparrow

Cliff Swallow.

Clivicola riparia

Coccothraustes vespertina

\section{Coccyges}

Coccygin:

Coccyzus

americanus erythrophthalmus

Colaptes auratus.

Colinus virginianus

Columb»

Columbidx

Colymbus auritas holbollii ...

Compsothlypis americana.

Connecticut Warbler

Contopus borealis virens

Conurus carolinensis

Cooper's Hawk

Coot

American Sea

Coots

Cormorant. Double-crested

Cormorants

Corvida

Corvine

Corvus

americanus.

corax sinuatus

('ow Bird

Cow Bunting

Crake Yellow

Crane

Little Brown

Sandhill

White
Page.
Crane, Whooping

Cranes

('reeper

American

Black and White

Brown

Creepers ......... $12 t$

Crested Flycatcher ........................... 82

Cricket Sparrow .................. 97

Crossbill _.............................. 93

American ..................................... 93

Red $\ldots$

White-winged ............................. 93

('row

American ................................... 86

('row Blackbird ................ 90

Crows 86

Common ......... -............... 46

Crymophilus .............................. 47 fulicarius.................................... 47

Cuckoo ........................................... 72

Black-billed.............................. 73

Yellow-billed .............................. 73

Cuckoos.................... 72

American .......... 72

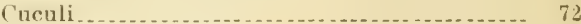

Cuculidie .......................................... 72

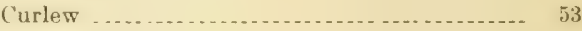

Eskimo . . -

Hndsonian

Jack.........-. 53

Long-billed ....................................... 53

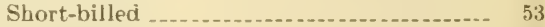

Sickle-billed.... 53

Curlew Sandpiper............... 50

Cyanocitta..................................... 85 cristata...................... 45

Cygnina _..................................... 40

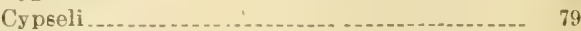

Dabchick

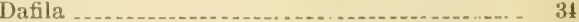
acuta

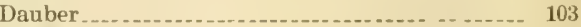

Mrod ...................... 1v3

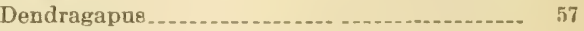
canadensis

franklinii

Dendroica ..._._............................. 112

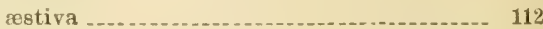

blackburnia ................... 114

cærulea .......................................... 113

crerulescens_............................. 112

castanea - 114

coronata _... .

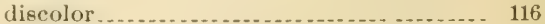

dominica ................................. 5

dominica albilora....................... 114

kirtlandi

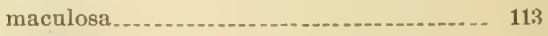

palmarum ....... 116

pensylvanica._.......................... 113

striata

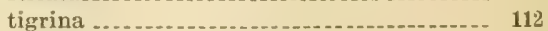

vigorosii - ...

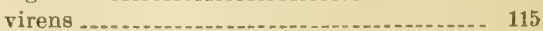


Dickcissel

Didapper.

Dipper

Diver.

Black-throated

Great Northern

Hell

Red-throated.

Diving Birds.

Doe Bird

Lesser

Dolichonyx

oryzivorus

Double-crested Cormorant

Dough Bird

Dove

Carolina

Morning

Dowitcher

Long-billed

Downey Woodpecker

Dryobates

pubescens.

villosus

Duck

American Eider.

American Golden-eve

American Scaup.

American Senter.

American Midreon.

Baldrate

Barrow's Golden-eje.

Black

Black Jack

Blue-winged Teal

Buftle-head

Butter-ball

Canvas-back

Dusky.

Eider (American

Eider (King)

Fish..

Gadwall

Garrot

Golden-eye.

Greater Blackhead

Greater Blue-bill

Greater Scaup.

Green-head

Green-winged Teal

Harlequin

King Eider

Lesser Black-head

Lesser Blue-billed

Lesser Scaup

Long-tailed .

Mallard

old Squaw

Old Wife.

Pintail

Redhead.

Ring-neck.

Ruddy

Sea Coot

Shoveller
Page.

101
25

25
Page.

Duck, Spirit ................................ 37

Spoonbill ........................ 34

Surf Scoter .............................. 38

Tree

Velvet Scoter............................... 33

Whistler

White-winged Scoter...................... 38

Widgeon

Wood ....................... 35

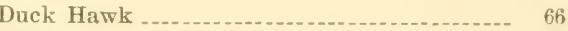

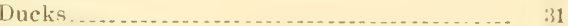

Dunlin ..............................................

American ........... 50

Eagle........

Bald . ............. 65

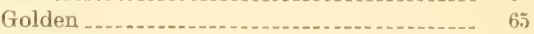

Eave Swallow ......... 103

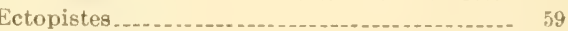

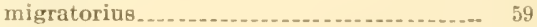

Egret

American .................................... 43

Little White _.............................. 43

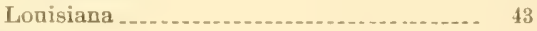

Egrets. 41

Eider. ......................................... 38

American _._. 38

King ...................................... 38

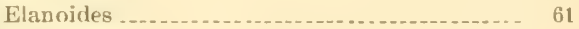

forficatus . .............................. 61

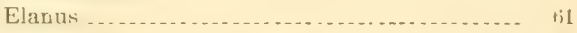

lencurus.................................. bi

Empidonax ......................................

acadicus...n. 83

flaviventris_................................. 83

minimus ............. 83

pusillus trailli

Engliøh Sparrow ..._._.

Law for destruction of ................... 8

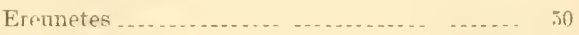
pusillus .... 50

Erismatara................................... 38

rnbida 99

Eskimo Curlew _._._._._._._.................... 54

Earnpean Sparrow .......................... 96

Evening Grosbeak ................................ 91

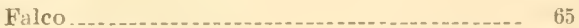

columbarins ........ 66

peregripus anatum

rusticolus gyrfalco _._.

sparverius_._.

Falcon 66

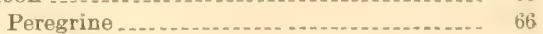

Falcones .............

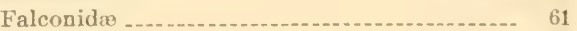

Falconinw .... ... . . .

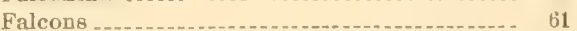

Field Plorer .............. 52

Field Sparrow

Field Swallow.

Finch

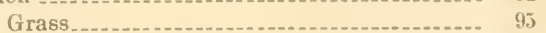

Indigu Painted ........................... 101

Lark .

Nelson's Sharp-tailed......................... 97 
Page.

Finch, Pine

Purple

Finches

Fire Bird

Fish Duck.

Fish Hawk

Flicker.

Florida Gallinule

Flycatcher

Acadian

Crested

Great Crested

Least

Olive-sided.

Pewit

Small Green-crested

Traill's

Tyrant

Yellow-bellied

Flycatchers.

Tyrant

Fly up the Creek.

Foster's Tern

94

92

80

81

Fox Sparrow

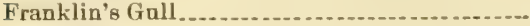

Fratercula

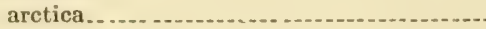

Freshwater Marsh Hen.

Fringilladæ

Fulica americana

Fulicinæe

Gadwall

Galeoscoptes carolinensis

Gallinaceous Birds

Gallinie

Gallinago

delicata.

Gallinula

galeata.

Gallinule

Florida

Gallinules

Gallinulinæ

Game Warden

Garrot law regarding

Garrulina

Geese

Gelochelidon nilotica

Geothlypis agilis

formosa philadelphia trichas

Glancionettia clangula americana islandica

Glaucus Gull

Glossy Ibis

Gnatcatcher

Blue-gray
Gnatcatcher8

Page.

128

Goat Sucker $\ldots \ldots \ldots$

Goat Suckers .................................. 77

Godwit

Great Marbled ............................. 51

Hudsonian .... 51

Marble ....

Golden Crowned Kinglet.......................... 127

Golden-crowned Thrush

Golden-crowned Warbler.................... 113

tolden Eagle

Golden-eye ...................................... 36

American ...... 36

Barrow's ... 37

Golden Swamp Warbler ..................... 110

Golden-winged Warbler ....................... 111

Golden-winged Woodpecker................... 77

Goldfinch _ American ........ 94

ioose

American White-fronted $\quad 39$

Blue _.......................................... 39

Brant - 40

Cackling .................................... 40

Canada -... 40

Common Wild

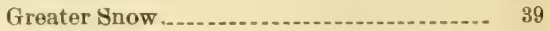

Hutchin's

Lesser Snow................................. 38

White-cheeked - 40

Goosander . 31

Grackle....................... 90

Bronzed

Rusty _._._.

Grass Finch

Grasshopper Sparrow _........................ 97

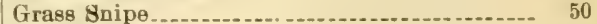

Grayback 49

Gray-backed Snipe_............................ 49

9 Gray-cheeked Thrash....._.............. 129

46 Gray Phalarope .................................... 47

46 Gray Snipe

46 Great Black-backed Gull........................... 27

46 Great Blue Heron .............................. 43

45-46 Great Crested Flycatcher

46 Great Gray Owl .............................. 68

8 Great Horned Owl .

8 Great Northern Diver......................... 25

36 Great White Egret................................ 43

Great White Heron

Greater Blue-bill duck .......................... 36

29 Greater Redpoll

29 Greater Scaup Dack............................. 36

17 Greater Snow Goose.......... 39

Greater Tattler

Greater Telltale............................... 51

Greater Yellow-lege

Grebe....... 24

Carolina

Holbœell's . .

Horned

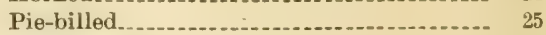

Red-necked................................ 24

Western .................................... 24

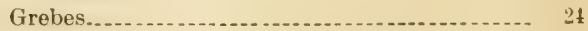


Greenback

Green Black-capped Yellow IVarbler

Green-head

Green Heron

Greenlet

Blue-headed

Brotherly-love

Red-eyed.

Solitary

Warbling .

White-eyed

Green-winged Teal

Grosbeak

Cardinal

Evening

Pine

Rose-breasted

Ground Bird

Ground Robin

Gronse

Canada.

Pinnated

Ruffed

Grus

americanus

canadensis

mexicana

Grues

Gruidae

Gull

American Herring.

Black-headed

Bonaparte's.

Franklin's

Glaucus

Great Black-backed

Herring

Iceland

Kittiwake

Laughing

Ring-billed

Sabine's

Smithsonian

White-winged

Gull-billed Tern

Galls

Gyrfalcon

Habia

ludoviciana.

Hæmatopus palliatus

Hair Bird

Hairy Woodpecker.

Haliatus.

leucocephalus.

Hang Nest

Harlequin Duck

Harporhynchus rafus

Harrier

Hawk

American Goshawk

American Rough-legged

American Sparrow

Broad-winged

Chicken
Page.

55
Page.

Hawk, Cooper's ................................ 62

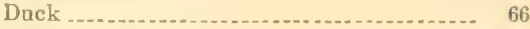

Fish ........................................... 66

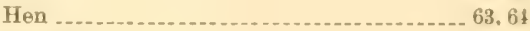

Marsh ..... 62

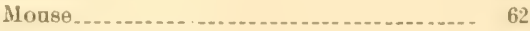

Night. .

Pigeon ...................................... 66

Red-shouldered _........................... 64

Red-tailed............................................. 63

Rough-legged _.............................. 64

Sharp-shinned -62

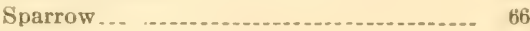

Swainson's _... 64

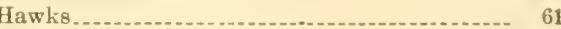

Hell Divers....................................... 24, 25

Helmintherus ................................ 110

vermivorus.................... 111

Helminthophila ............................ 111

celata

chrysoptera

peregriua ...................................... 111

pinus

ruficapilla_................ 111

Hemlock Warbler.

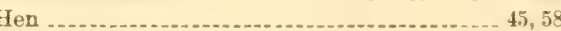

Marsh .................................. 45

Prairie

Hen Hawk ..... . . . . . . . . . .

Henslow's Bunting ............................... 97

Henslow's Sparrow

Herodii.... 41

Herodiones.................................. 4]

Heron -

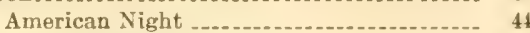

Black-crowned Night........................ It

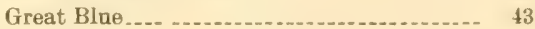

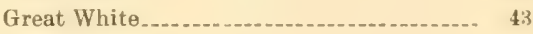

Green -

Louisiana.................................... 43

Snowy $\ldots . . . . . . . .84$

Herons ........... 41

High Holder................. 77

Himantopus .......... ts

mexicanus .................................. 45

Hirundinidro - 102

Histrionicus .............................. 34

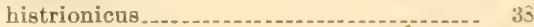

Holbœll's Grebe... ................. 24

Hooded Flycatching Warbler................. 118

Hooded Warbler.............................. 114

Hoot Owl........................................ 70

Horned Grebe. .... 24

Horned Lark............ St

Honse Pewee....................................... 82

House Wren .

Hadsonian Chickadeo......................... 127

Hudsonian Curlew

Hudsonian Godwit .............................. 51

Humming Bird

Raby-throated ................................ 80

Humming Birds .......................... 79

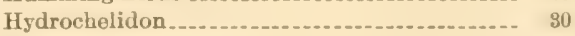

nigra surinamensis ........................ 30

Ibididre ........... 41 


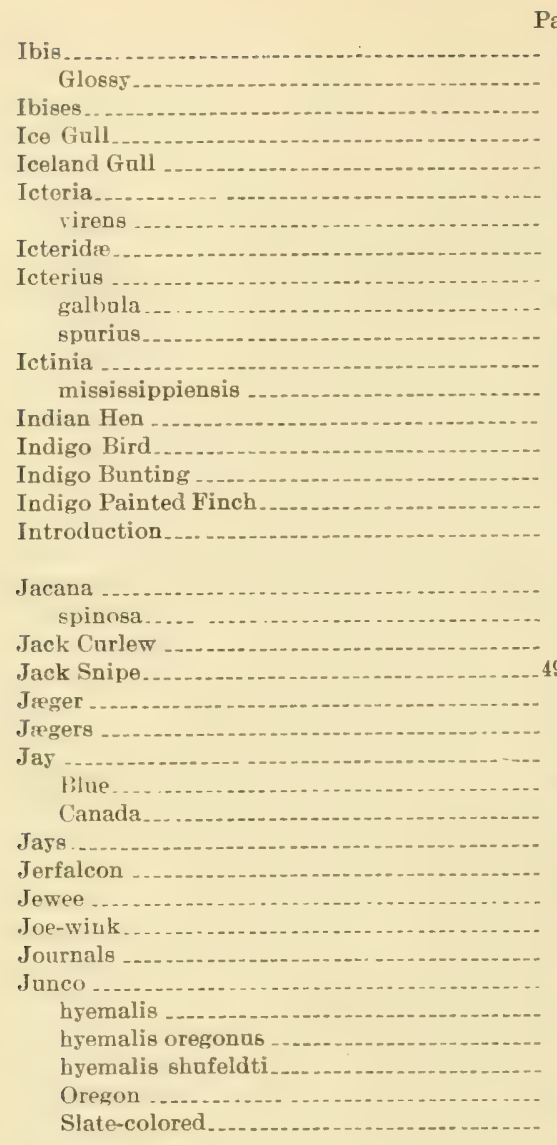

Kentucky Warbler

Kildeer.

Kildeer Plover...............................

King Bird.

King Eider

Kingfisher Belted

King fishers

Kinglet

Golden-crowned

Ruby-crowned

hinglets .

King Rail

Kirtland's Warbler

Kite

Black-shouldered -

Mississippi

Swallow-tailed

White-tailed

\section{Kites}

Kittiwake.

Knot

Lagopus .

lagopus
Page. $\quad$ Page.

41 Lamellirostral Swimmers ....................... 31

41 Laniidæ .......................................... 107

41 Lanius _.

27 borealis .................................. 107

27 ludoviciande

118 ludovicianus excubitoroides_............... 107

118 Lapland Longspur............................. 95

87 Large-billed wag-tail warbler.................. 117

\$9 Larida ...................................... 27

89 Larin $\sharp^{2}$

89 Lark .......... 8

61 Brown ........... 120

61 Horned

41 Little Meadow

101 Meadow

101 Prairie Horned ............................ 84

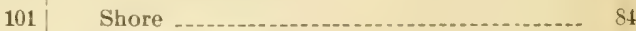

3 Western Meadow ........................ 89

Lark Finch.................................. 97

Lark Sparrow ...

Larks ....................................... $8 t$

53 Larus ... . .

9-50 argentatus smithsonianus................. 28

27 atricilla................ 28

27 delawarensis ................................. 28

85 franklinii ........... 2S

85) glancus .................................. 27

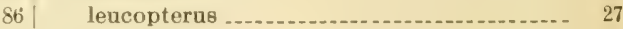

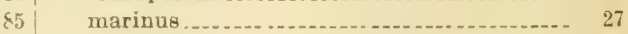

65 philadelphia ............................... 28

100 Laughing Gull ................................. 28

100 Least Flscatcher.............................. 83

10 Least Sandpiper...................................... 50

99 Least Teru ...................................... 30

99 Lesser Doe Bird ................................. 51

99 Lesser Redpoll............... 93

99 | Lesser Scaup Duck . ............... 36

99 Lesser Tattler......................................... 52

99 Limnicolæ

Limosa .................................................. 51

117 fedoa.

bæmastica -............ 51

Lincoln's Sparrow. . . .

Linnet _._.

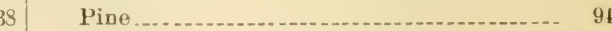

74 Redpoll

it Literature of Birds .......................... 10

73 Little Brown ('rane......................... 44

127 Little White Egret............................ 43

127 Log Cock .................... ib

125 Long-billed Curlew........................... 53

127 Long-billed Dowitcher...................... 49

45 Long-billed Marsh Wren .................... 12t

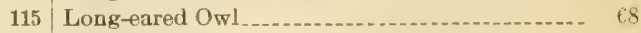

61 Longipennes - 27

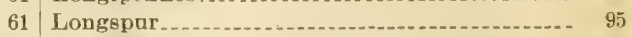

61 Lapland .................................. 95

$61 \quad$ Lapland 61 Painted

61 Smith's

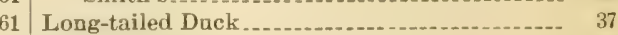

27 Long-winged Swimmers _._.

49 Loon

Black-throated........ 26

58 Red-throated............................... 26

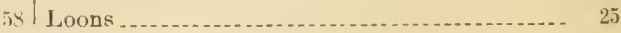


Page.

Lophodytes

cucullatus

Louisiana Egret

Louisiana Heron

Louisiana Water Thrush

Loxia.

curvirostra minor

lencoptera

\section{Macaws}

Macrochires.

Macrorhamphus

scolopaceus

Magnolia Warbler

Magpie

American

Magpies

Mallard

Marbled Godwit

Marsh Hawk

Marsh Hen

Fresh Water

Marsh Robin

Marsh Tern.

Martin.

Bee .

Purple

Sand

Maryland Yellow-throat

Meadow Lark. Little.

Meadow Starling

Megascops asio

Melanerpes carolinus erythrocephalus

Meleagrinæ

Meleagris galloparo

Melospiza

fasciata

georgiana

lincolni

Merganser

American.

americanus

Hooded

Red-breasted

serrator

Mergansers

Mergince

Merula migratoria

Michigan Bird Eanna

Michigan Bird Laws

Micropalama

himantopus

Micropodidæ

Milvalus tyrannas

Miminæ

Mimus

polyglottos

Mississippi Kite

32

43

43

117

92

93
Mottled Owl _....... 69

72 Mourning Dove.................................... 60

77 Mourning Warbler

49 Monse Hawk

49 Mud-dauber ......................................... 103

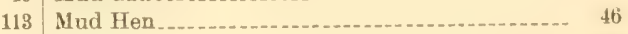

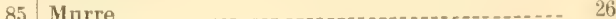

85 Murre......... 8 8:

crinitus ...................................... 82

Myrtle Warbler ............................. 113

Nashville Warbler ........................... 111

Nelson's Sharp-tailed Finch............... 97

Nelson's Sparrow _......................... 97

Night Hawk

Night Heron

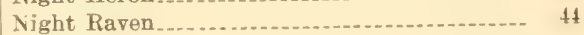

Northern Phalarope......................... 47

Northern Shrike. ....................... 107

Numenius.

borealis . .-. .

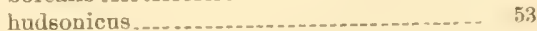

longirostris .............................. 53

Nuthatch ................................... 12.

Canada

Red-bellied_.................................. 125

Red-breasted ................................. 125

White-breasted ........................... 125

Nuthatches ................................ 12.

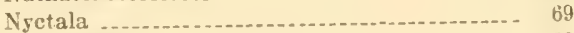

acadica 69

tengmalmi richardsoni . .................... 69

Nrctea ..................................... 71

nyctea................................... 71

Nycticorax ............ 44

nyeticorax nævius .........................

violaceus ................. 5

Oidemia...................... 38

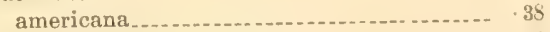

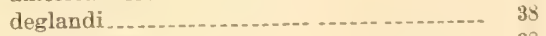

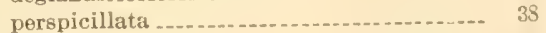

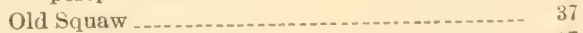

Old IVife 37

Olive-backed Thrush........................ 129

Olive-sided Flycatcher.......... 82

Olor

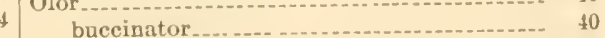

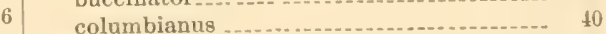

Orange-crowned Warbler...................... 111

Orange-throated Warbler"....................... $11 t$

Orchard Oriole

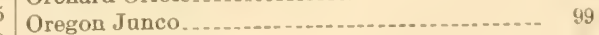

Oregon Snow Bird ........................ 99

Oriole _._.

Baltimore ....

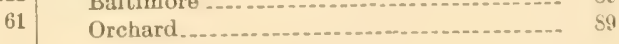


Orioles ......
Ortolan
Oscines
Osprey

American

Ospreys

Otocoris

alpestris . .

alpestris praticola

Oren Bird

Owl

Acadian

American Barn

American Hawk

American Long-eared.

Barred

Great Gray

Great Horned

Hawk

Hoot

Long-eared

Mottled

Prairie

Richardson's

Saw-rvhet.

Screech

Short-eared

Snowy

Western Horned

White

Owls

Barn...

Common

Painted Longøpar

Palm Warbler.

Paludicola.

Pandion

haliaêtus carolinensis

Pandioninie

Paridie

Pariner

Paroquet

Carolina

Paroquets

Parrots.

Partridge

Spruce

Partridges

Parula Warbler

Parus.

atricapildus

bicolor.

carolinensis

hudsonicus

Passer domesticus

Passerella iliaca.

Passerina

cyanea

versicolor

Passeres.

Pavoncella

pugnax
Page. 1 Page.

Pectorial Sandpiper 50

45,87 Peet weet ...................... 53

84 Pelecanider........................................ 31

66 Pelecanus _......................................... 31

66 erythrorhynchos _............................. 31

66 Pelican

81 American White $\ldots \ldots \ldots . . . . . . . . . . . . . .31$

84 Pelicaus.......................................... 31

84 Perching Birds

116 Perdicinæ ................................... 56

67 Peregrine Falcon

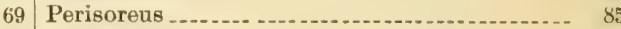

67 canadensis..... 86

71 Petrochelidon.............. 103

68 lunifrons....................................... 103

68 Pewee 88

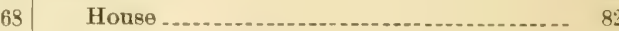

70 Wood

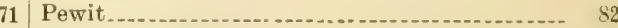

8, 70 Pewit Flycatcher._._.........................

63 Phalacrocoracide .............................. 30

69 Phalacrocorax............................................ 31

68 carbo ....-3t

69 dilophus...................................... 31

9 Phalarope .................. 47

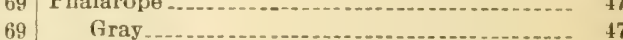

$68 \quad$ Northern

71 Red-necked............................... 47

71 Wilson's .... 47

67 Phalaropes _._. 47

67 Phalaropodidie ............................ 47

67 Phalaropus............................ 47

lobatus ........................ 47

tricolor

116 Phasiani ..................................... 56

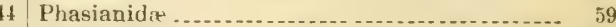

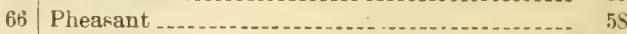

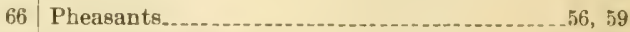

66 Philadelphia Vireo.... ...................... 108

125 Philip Sparrow ................................. 96

126 Philohela . . . . . . . . . .

72 minor

72 Phobe

72 Pica

72 pica hadsonica

57 Pici 74

57 Picidæ.............. 74

56 Picoides .

112

126

127

126

5

127

.96

96

100

100

101 Pine Finch .................................... 94

101 Pine Grosbeak 91

101 Pine Linnet....................................... 94

81 Pine Siskin ................................. 94

5 Pine Warbler..... 115

5 Pinicola ....................................... 91 
Pinicola, enucleator

Pinnated Gronse

Pintail

Pipilo

erythrophthalmus

Piping Plover

Piping Ring Pluver

Pipit American.

Pipits

Piranga

erythromelas rubra.

Plectrophenax nivalis.

Plegadis axtumnalis

Plover.

American Golden.

Belteci Piping

Black-bellied

Bull-head.

Field

Kildeer

Piping

Piping Ring .

Prairie

Ring

Ring-neck

Semipalmater

Upland.

Plovers

Plum Pudden

Pochard American

Podicipedes

Podicipidæ

Podilymbus podiceps

Polioptila cæralea

Polioptilin $x$

Pomarine, Jrger.

Pooc retes. gramineus

Porzana carolina noveborecensis

Prairie Chicken.

Prairie Hen

Prairie Horned Lark

Prairie Owl

Prairie Plover

Prairie Warbler

Progne subis

Prothonotary Warbler

Protonotaria citrea.

Poittaci.

Psittacidze

Ptarmigan (Willow)

Puftin

Purple Finch

Parple Martin.
Page.

91 Quai

Quiscalas

quiecula

quiscula reneus

Rail

King

Red-breasted ................................. 45

Virginia _an- 45

Yellow ................. 46

Ralli....

Rallide _.............................. 45

Rallinie.................................. 45

Rallus

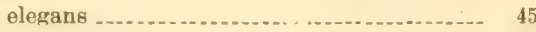

longirostrig crepitans.

virginianus............................ 45

Rails - $44-45$

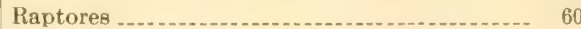

Raren .............................. 86

Night ......

Razor-billed Auk .............................. 26

Recurvirostra

americana.............................. 48

Recurvirostridis ..... 48

Red-bellied Nuthatch...................... 125

Red-bellied Woodpecker .................... 77

Redbird _. 100,102

Black-winged ............................. 102

Summer

Virgınia....................................... 100

Red-breasted Nuthatch ......___._..... 125

Red-breasted Sandpiper...................... 49

Red-breasted Snipe..................... 49

Red Crossbill...................... 93

Red-eyed Greenlet .................................. 108

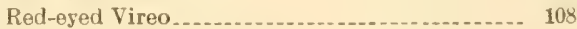

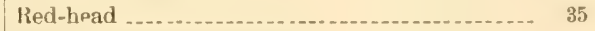

Read-headed Woodpecker ................. 77

Red-necked Grebe ............................. 24

Red-necked Phalarope.................... 47

Red Phalarope............................... 47

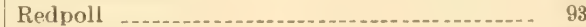

Common 93

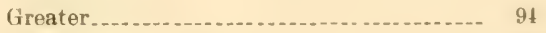

Lesser

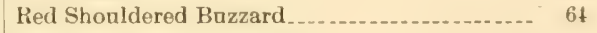

Red Shonldered Hawk ............ 64

Red-shouldered Blackbird.................... 88

Redstart....... 119

American $\quad 119$

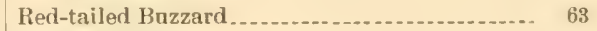

Red-tailed Hawk ............................... 633

Red-throated Diver ......................... 26

Red-throated Loon

Red-winged Blackbird........................ gi

Reed Bird........................ 87

Regulus

calendula

$\begin{array}{lll}\text { satrapa } & 127\end{array}$

Regulinn .................................... 127

Rice Bird ............. 87

Richardson's Owl .......................... 69

Ring-billed Gull

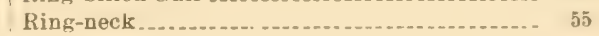




Ring Plover
tridactyla
Robin
$\quad$ Ground
$\quad$ Marsh
$\quad$ Swamp
Robin Snipe
Roseate Tern
Rose-breasted Grosbeak
Rose-breasted Song Grosbeak
Rough-winged Swallow.
Royal Tern
Ruby-crowned Kicglet.
Ruby-throated Humming Bird
Ruddy Dack .
Ruffed Grouse.......
Rusty Blackbird
Rusty Grackle

Sabine's Gall

Sanderling

Sandhill Crane

Sand Martin

Sandpiper ..

American Green

Baird's

Bartramian

Black-bellied.

Boneparte's

Buff-breasted

Curlew

Least.

Pectoral

Red-backed

Red-breasted

Semipalmated

Solitary

Spotted

Stilt

White-rumped

Sandpipers.

Sand Swallow

Sap Sucker

Yellow-bellied

Sarcorbamphi

Savanna Sparrow .

Saw-bill

Saw-whet Owl

Sayornis

phœebe.

saya.

Scarlet Tanager

Scaup Duck

Greater

Lesser

Scolecophagus

carolinus

Scolopacidit

Scoter

American

American Black

Surf

Velvet

White-winged
Page.

5
Page.

cotiapteryx _... cinerea _- 68

Sicreech Owl

Sea Coot ............... 39

Sea Dove 27

Sea Swallows . .

Seiurus ... 116

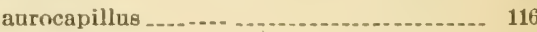

motacilla _....... 117

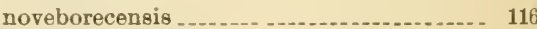

Semipalmated Plover........... 55

Semipalmated Sandpiper.

Semipalmated Tattler _._._.

Setophaga. . .

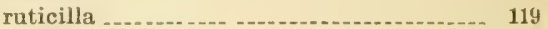

Sharp Shinned Hawk ..................... 62

Shore Birds _...

Shore Lark.................

Short-billed Curlew .......................... 53

Short-billed Marsh Wren _... 123

Short-eared Owl ......... 68

Short-tailed Tern _............ 30

Shoreller.................................. 34

Shrike

Northern .............. 107

Logger-head . . .

White-ramped

Shrikes.... _._.

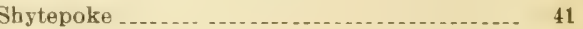

Sialia............. 131

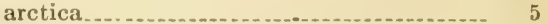

sialis _. 131

Sickle-billed Carlew..._..._._._._._..... 53

Sylvania _..._..._.

canadensis _........... 119

mitrata. . .

pusilla ............. 119

Siskin

Pine

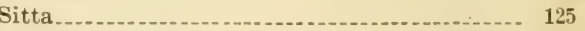

canadensis ............... 125

pusilla._. . .

carolinengis . _.

Sittinæ....

Skuas .... . .

Skank Blackbird ........................... 87

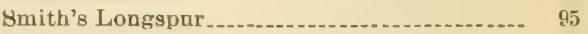

Smithsonian Gull

Snipe

American . . . . . . . .

Grass.....

Gray _.. _ _ _ _

Gray-backed ..................... 49

Jack _._.

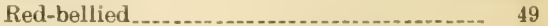

Kobin............... 49

Stone_...

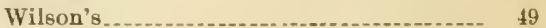

Snipes

Snow Bird . .

Black........... 99

Common_._._._._. 99

Oregon . .

White....... 94

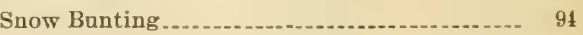


Snow Flake

Snow Goose

Greater.

Lesser.

Snows Heron

Snowy Owl.

Solitary Greenlet.

Solitary Sandpiper

Solitary Tattler

Somateria

dresseri

mollissima borealis

spectabilis.

Song Birds

Songless Perching Birds

Song Sparrow

Sooty Tern

Sora

Sparrow

('hipping -

Clay colored

Cricket.

English.

European

Field.

Fox

Grasshopper

Henslow's

Lark.

Leconte's

Lincoln

Velson's.

Philip.

Red

Savanna

Song

Swamp.

Tree.

Vesper.

White-browed

White-browed Crowned

White Crowned.

White-throated

Yollow-winged

Sparrows

Syatula .

clypeata.

Sphyrapicus

varius

Spinus .

pinus.

tristis

Spirit Dack

Spiza.

americana

Spizella

monticola

pallida

pusilla

socialis

Spoonbill

Spoonbills

Spotted Sandpiper

Spotted Tattler

Sprigtail.
Page. $P a g e$.

94 Spruce Partridge......................... 57

38 Square-tailed Barn Swallow.................. 103

39 Soquawk ...................................... 41

38 Stake Driver................................... 41

43 Starlings .......................... st

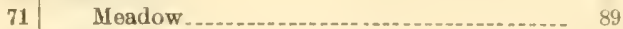

109 Steganopodes

52 Stelgidopteryx _............ 101

52 Serripennis 101

38 Stercorariidø _.................. 27

38 Stercorarius ...............................

5 pomarinus

38 Sterna._-_.- 29

81 antillarum

dougalli

fuliginosa . . ............................ 30

hirando .

maxima

paradisura.........

tschegra va ..._.

Sternninit ....................................

Stilt

Black-necked. ............................. 48

Stilt Sandpiper _.............. 49

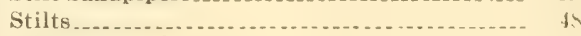

Striges _...

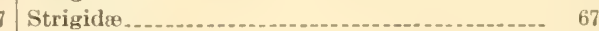

Strix

pratincola............................... 67

Stone Snipe_................................... 51

Storks .

Sturnella....................................... $\delta 9$

magna _......... 89

magna neglecta............................ 89

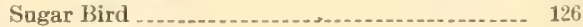

Sula bassana

Summer Duck ............. 35

Summer Red Bird ........... _......... 102

Summer Tanager ......... . . . . . . . . . . . ... 102

Surf Birds ....... 56

7 Surf Duck ...................................... 35

8 Surf Scoter .................................... 35

7 Surnia ................................ 71

ulula caparoch.

Swainson's Hawk ............................. 64

Swallow 103

Bank ............................ 104

Barn

Blue-backed _._.............................. 104

Chimney - 79

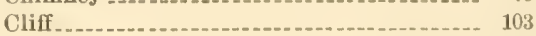

Eave 103

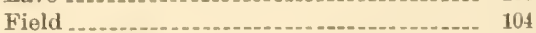

Rough-winged ..................... 104

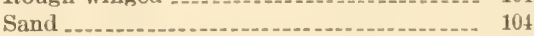

Square-tailed Barn ........................... 103

Treo

White-bellied ..........._._. 104

Swallows__._................... 102

Swallowed-tailed Kite _._..._._.......... 61

Swamp Angel

Swamp Robin ................ 129, 130

Swamp Sparrow ............................. 100 


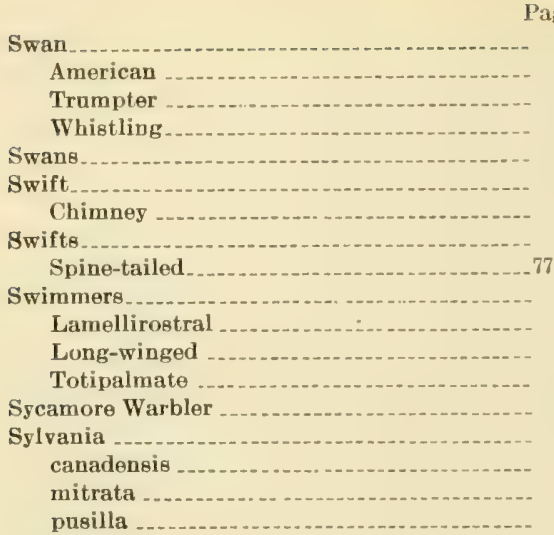

Sylviidze

Symphemia semipalmata

Synthliboramphus antiquas

Syrnium nebulosum

Tachycineta. bicolor.

Tanager .

Scarlet

Summer

Tanagridiz

Tattler

Bartramian

Greater.

Lesser.

Semipalmated

Solitary

Spotted

Teal

Blue-winged

Green-winged

Teeter-tail

Telltale

Tennessee Warbler

Tern

Arctic

Black

Caspian

Cayenne

Common

Foster's

Gull-billed

Least

Marsh

Roseate

Royal

Short-tailed

Sooty

Wilson'

Terns

Tetraonidre

Thistle bird

Thrasher

Brown
Page.

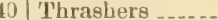

40 Thrush._._.

40 Brown _..._... 121

40 Giolden-crowned ............................. 116

$31 \quad$ Gray-cheeked ............................. 129

79 Hermit 130

79 Louisiana Water._._. 117

$\begin{array}{ll}\text { Olive-backed } & 121 \\ \text { Small-billed Water. } & \end{array}$

77- 79

31

31

27

30

114

118

119

118

127

52

52

26

1

102

102

102

51

52

51

52

52

52

53

33

33

33

53

51

111

29

, 29

30

29

Song .....

Swainson's _.................................. 129

Water .................. 116

Wilson's _.. 129

Wood _._.

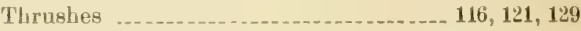

Thryothorus ............................... 122

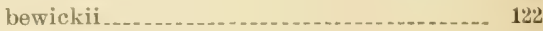

ludovicianns ................................ 122

Thunder Pumper.................................... 41

Tip-up

Tit Lark

American.

Tit Lark Warbler............................... 116

Titmice _.......................... 126

Titmouse

Black-fronted ........................... 126

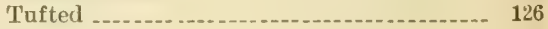

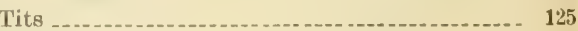

Tomtit _._.

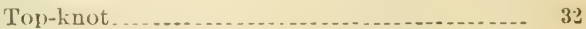

Totipalmate Swimmers ....................... $\quad 30$

Totanus.......................................... 51

flavipes..................... 52

melanoleucus _._....................... 51

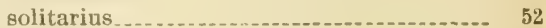

Towhee ... . . . . . . . . . . 100

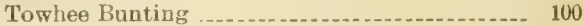

Traill's Flycatcher.............. 83

Tree Duck...................................... 3.

Tree Sparrow _._. . . . . .

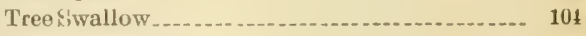

Tringa _._._._...... 49

alpina pacifica

bairdii ...................... 50

canutus

ferruginat -.................... 50

fuscicollis -

maculata_... 50

maritima........ 5

minutilla

Trochili _.................................. 79

Trochilidie ................................ 79

Trochilus ............... 80

colubris

Troglodytes _... . . .

aëdon

hiemalis........... 123

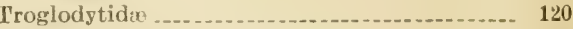

Troglodytina ................................. 122

Trumpter Swan ............................ 40

Tryngites ........... 53

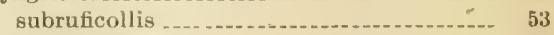

Tufted Titmouso ................................... 126

Turdidico ........................................ 129

Turdinat .... . . . . . . . . . 


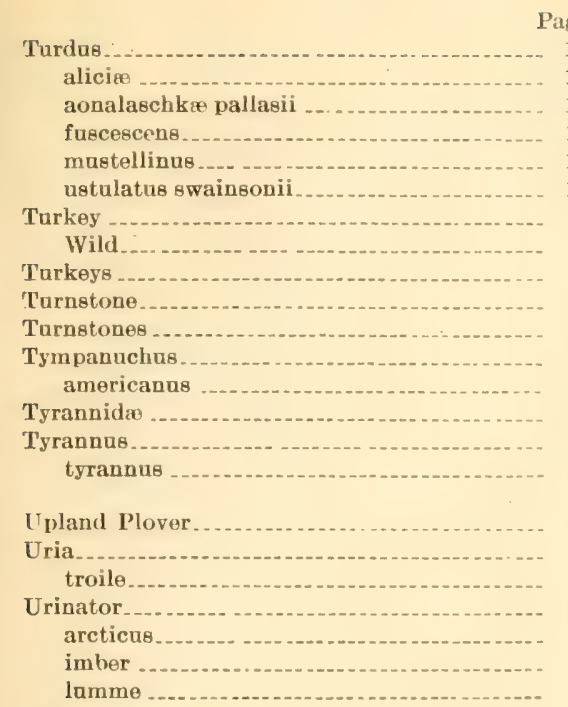

Urinatoridio

Varied Bunting.

Veery

Velvet Scoter.

Vesper Sparrow.

Vireo

flavifrons

gilvus.

noveboracensis

olivaceus.

philadelphicns

solitarius

Vireo

Blue-headed.

Brotherly Love

Philadelphia

Red-eyed .

Warbling . .

White-eyed.

Yellow-throated

Vireonidio

Vireos.

Virginia Red Bird

Vulture Tarkey

Vultures

$$
\text { American }
$$

Wagtail

$$
\text { Wood }
$$

Wagtail Warbler

Wagtails

Warbler.

Bay-breasted

Black and White.

Black and Yellow.

Blackbarnian

Black-capped Yellow

Black-poll

Black-throated Blue
Page.

129
Page.

arbler, Black-throated Green

Blue.... 113

Blue Golden-winged..................... 111

Blue-winged ................................ 111

Blue-winged Yellow........................ 111

Blue Yellow-backed...................... 112

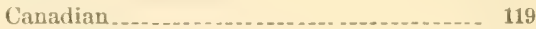

Canadian Flycatehing

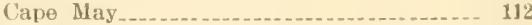

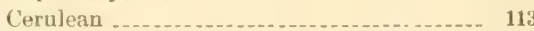

Chestnut-sided.......................... 113

Connecticut.................. 117

Golden-crown _........................... 113, 127

Golden Swamp ...................... 110

Golden-winged ............................ 111

Green Black-capped jellow _............. 119

Hemlock

Herited .................................. 11

Hooded Flycatching

Kentucky _._._.

Kirtland's _............................. 115

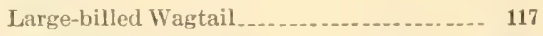

Magnolia _._. 118

Maryland Yellow-throat_._._._._._._._._. 118

Mourning ................................. 117

Myrtle_._._._._. 113

Nashville_.............................. 111

Orange-crowned ._......................... 111

Orange-throated _...................... 114

Palm _. 116

Parala ....................................... 112

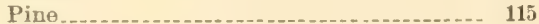

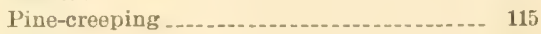

Prairie _............ 116

Prothonotary . .

Sycamore.................................. 114

Tennessee ...n-me 111

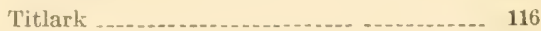

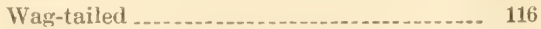

White-browed Yellow-throat............. 114

Willow

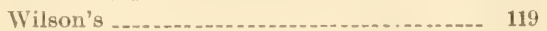

Worm-eating.................. 111

Yellow _

Yellow Redpoll. ............ 116

Yellow-rumped............................. 113

Yellow-throated Ground $\ldots . . . . . . . . . . . .118$

Warblers ................................... 109

Wood....... 109

Warbling Greenlet.

Warbling Vireo ................................. 108

Water Wagtail ................................. 111

Waterwitch ................................. 25

Waxwing .................................... 105

Bohemian . .

Cedar

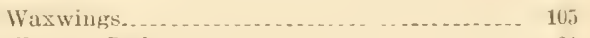

Western Grebe .................. 24

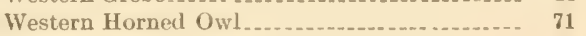

Western Meadow Lark.................... 89

Whip-poor-will .................... 78

Whistler _............... 36

Whistling Swan........................ 40

White-bellied swallow ..................... 10 .

White-breasted Nuthatch........................ 125 
White-browed Crowned Sparrow

White-browed Sparrow.

White-browed Yellow-throated Warbler.

Whitecheoked Goose.

White-crowned Sparrow

White-esed Vireo

White Owl

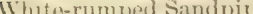

VWhite-romped Shrike

White Snow Bird

White-tailed Kite.

White-throated Sparrow

White-winged Crossbill

White-winged Gall.

White-winged Scoter

Whooping Crane

Widgeon

American

Willet

Willow-IVarbler

Wilson's Phalarope

Vilson's Snipe

Vilson's Tern

Wilson's Thrush

Wilson's Warbler.

Winter Wren

Woolcock

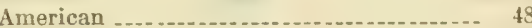

Wood Duck ... . .

Woodland Warblers

Woodpecker

American Three-toed

Arctic Three-toed

Banded-backed Three-toed

13lack

Black-backed Three-toed

Doway

Golden winged

Hairy.

Pileated.

Red-bellied

Red-headed

Yellow-bellied

Voodpeckers

Wood Peweo

Wood Thrush
Page.

Worm-eating IVarbler _.... 111

Wren . 122

Bewick's 122

Big Brown ................... 121

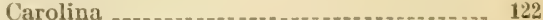

Golden-crowned ....._.................. 127

House

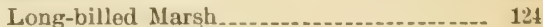

Rubs-crowned . .

Short-billed Marsh.......................- 123

Winter _............... 123

Wrens -... 120

Xanthocephalus _............................. 85

xanthocephalus 88

Xema....................... 29

sabinii $\quad 29$

Yellow-bellied Flycatcher _..._.

Yellow-bellied Sap Sucker.................... 76

Yellow-bellied Woodpecker.

Yellow-billed Cackoo 73

Yellow-breasted Chat _............. 118

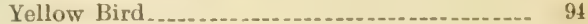

Summer .... 112

Yellow Crake_...

Yellow Hammer............................ 77

Yellow-headed Blackbird .................... 88

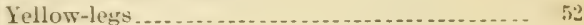

Greater .

Yellow Redpoll Warbler.._................ 116

Yellow Rail............... 46

| Yellow-ramped Warbler_._.

Yellow Shanks ...- 52

Yellow-throat _...

Marvland. ........................................ 118

Yellow-throated Ground Warbler............ 118

Yellow-throated Viroe _.___._._._._._... 109

Yellow Warbler......................... 112

Yellow Winged Sparrow

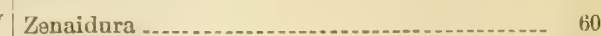

macroura._._.

Zonotrichia

albicollis _....... 95

leucophrys _...... 97 



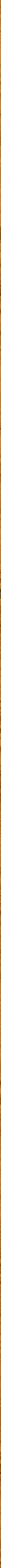


